\title{
Land-cover choices and governance structures: lessons from Māori
}

\section{By Sandra Liliana Cortés Acosta}

\author{
A thesis submitted to Te Herenga Waka - Victoria University of Wellington \\ In partial fulfilment of the requirements \\ for the degree of Doctor of Philosophy in Environmental Studies
}

Te Kura Tātai Aro Whenua - School of Geography, Environment and Earth Sciences

August 2020 

A mi tío Martiniano Acosta (1952 - 2018), de quien aprendí el sentido de la gratitud, el trabajo, la humildad y la valentía. Gracias por enseñarme que vinimos a bailar al compás de la vida. De esa manera, cuando sea tiempo de partir, nos iremos en paz y sin arrepentimientos por no haber disfrutado de la vida.

In memory of my uncle Martiniano Acosta (1952 - 2018), from whom I learned the sense of gratitude, work, humility and courage. Thank you for teaching me that we came to dance to the beat of life. Therefore, when it is time to leave, we will do it in peace and without regrets for not having enjoyed life. 


\section{Abstract}

Decisions on land utilisation and management have socio-economic and environmental implications. In this study, I use a mixed-methods approach to explore how Māori land governance structures influence decisions on land utilisation and hence greenhouse gas (GHG) emissions associated with rural activities on Māori freehold land.

General land and Māori freehold land are the main land statuses in Aotearoa New Zealand. General land, under private ownership, is not subject to the distinct statutory regime of Māori freehold land and can be owned by any New Zealander. Māori freehold, under collective 'ownership', is regulated by the Te Ture Whenua Māori Act 1993 (TTWM) and its 'ownership' is based on a customary regime and ancestral connections.

The TTWM provides a range of legal entities, including the two Māori land governance structures examined in this thesis - Māori incorporations and Ahu Whenua trusts - to facilitate decision-making and to administer land and assets on behalf of the 'owners'.

First, I explore how Māori land governance structures influence decisions on land utilisation and management. I discuss three case studies of Māori farms administered by different governance structures involved in agribusiness. Their decision-making process structure can be separated into two levels: the governance of the land and the operation of the enterprise. Maori land governance structures help to make 'successful' decisions, by balancing landowners' interests with optimal operation and performance of the agribusiness. This success not only depends on the legal constitution of the governance structure, but also on processes that are highly variable due to cultural and social values, and the capability of the board members to reach decisions.

Second, I explore decision-making processes concerning carbon farming, an opportunity to receive carbon credits from reforestation or afforestation. Face-to-face semi-structured interviews with a small group of Māori landowners revealed two central decisions: switching to forestry and joining the New Zealand Emissions Trading Scheme (NZ ETS). Forestry provides an economic opportunity to access long-term capital through timber harvests: but carbon farming is a relatively new experience, which provides additional short-term revenue prior to harvesting.

Third, I extend the qualitative analysis by econometrically modelling the relationship between Māori land governance structures and land-cover choices. I use maximum likelihood methods to estimate the probability of allocation of land in 2012 and the probability of land-cover transitions between 1997 and 2012. For Māori freehold land, 
there is a positive relationship between having a Māori land governance structure in place and the allocation of land in 2012 in forestry and a negative association with pasture. From 1997 to 2012 Māori land governance structures were associated with more transitions to forestry and fewer transitions into scrub.

Four, using hypothetical scenarios, I build on the econometric model of land-cover transitions to compare the effects of transitions between forestry, pasture and scrub across the period 1997-2012, and the role of the Māori land governance structures. I examine the implications of these transitions for private land and Māori freehold land in terms of both carbon dioxide equivalent and warming equivalent. Overall, Māori freehold land governance structures in the hypothesised scenarios would lead to an increase of the amount of carbon sequestered, relative to the actual levels of sequestration observed. The current way of counting GHGs leads to a much lower estimate of the contribution in reductions to the impact of warming.

Understanding drivers for these decisions can help to identify areas for the development of effective public policies regarding climate change mitigation. 


\section{Mihimihi}

Tukua te wairua kia rere ki ngā tihi taumata Hai ārahi i à tātou mahi.

Me tā tātou whai i ngā tikanga a rātou mā Kia mau kia ita, Kia kore ai e ngaro, Kia pupuri.

Kia whakamaua Kia tina! TINA! Hui e! TĀIKI EI

Whatungarongaro he tangata, toitū te whenua, toitū te whenua, toitū te whenua.

Mauri ora tūhāhā ki a Io Matua o Te Kore, ki a Rangi i àteanui, ki a Papatūānuku. Hekeheke iho rā, ko ue Uenuku, ko ue Uerangi ki tai Tanganui, ki tai Tangaroa. E au ai āku mihi ka rewa ki ngā hau pūpuhi mai Los Andes ki Tūteremoana a Kāpiti, mai

Kāpiti ki Hikurangi, ki Pukehinau, ki Maungahaumia, e kui mā e koro mā i te pō, moe mai, moe mai na.

E ngā uri a Te Tairāwhiti, a Porourangi, a Mahaki, kei te mihi maioha ki ōu koutou awhi, ou koutou tautoko ōu koutou manaakitanga ki tēnei mahi rangahau, mō tēnei tuhinga whakapae mai ngà whānau i a rohe, i a rohe, mō te iwi Mãori, mo ngā iwi taketake o te ao,

tènā anō hoki koutou e rau rangatira mā.

Kei te mihi maioha hoki, ki te iwi Ngāti Toa Rangatira, ki te whānau Barrett ki Waiorua, mō koutou kaitiakitanga ki au. I kāti au i konei

ki Kāpiti, tau mai rā te ngākau a tēnei manu pora.

Kei te mihi mìharo ki te poukarakia mo tēnei Tuhinga whakapae, mo te mihimihi $i$ tuhituhi nei, he uri a Te Peehi Kupe, te whānau

Te Hiko, e Toa Waaka, kia ora rawa atu koe.

Tènei te mihi maioha ki ngā iwi nō ngā hau

e whā, mai te hiku o te ika, ki te tai rāwhiti, mai te tai hauauru ki te Ūpoko o te Ika, whakawhiti atu te Moana a Raukawakawa, ki Te Waipounamu, anei he koha iti pounamu nei ki te awhina o koutou whawhai, hei hoki ano ki te tūranga kaha ki rō whenua tūpuna. No reira,

Tènā koutou, tēnā koutou, tēnā tātou katoa.
Allow one's spirit to extend its potential, to guide us in our work as well as in our pursuit of our ancestral traditions. Take hold and preserve it. Ensure it is never lost, hold fast.

Secure it and draw together! Affirm together as one!

The vision of people may change, but the land will always remain.

I recognise the origin source of life from Earth mother, to our radiant Sun, back to the parent force of the void from whence the waters of life descended from over the oceans of time and space immemorial.

My esteemed acknowledgements rise upon the winds of my sacred mountain Los Andes extending out to Tüteremoana of Kāpiti, to Hikurangi, Pukehinau and Maungahaumia, to your beloved ones who have passed on, sleep now, the long sleep.

To the descendants of Porourangi and

Mahaki, my affectionate acknowledgements extend to you all for your hospitality, your openness and embracive nature that has supported me in this much needed research around the families and tribes but also its value to other first nations of the world, I thank you for your gracious leadership.

I also would like to acknowledge the Barrett family of Ngāti Toa from Waiorua on Kāpiti for your guardianship to this foreign migratory bird who landed on Kāpiti, where my heart still reminisces, thank you.

I also would like to thank Toa Waaka, a descendant of Te Peehi Kupe and the Te Hiko whannau for your cloak of protection in the words of your ancestral karakia for this thesis, and for your support to compose this mihimihi I thank you.

This is an acknowledgement to the many iwi from the four directions from the top of the north island, crossing the Raukawakawa strait to the bow of the waka of Maui in the greenstone waters of the south, this is but a little gift of greenstone to you all, that it may assist you in any way during your fight to return to your rightful stronghold, with your whenua beneath your feet and your destiny within yours and your children's hands. I acknowledge, those who have passed, those who I have met and those I am yet to meet. 



\section{Acknowledgements}

I remember the first day the option of doing a PhD came to my mind. The idea of achieving such a significant level of qualification was exciting and intimidating. At that time, I did not imagine that working on this thesis would be such challenging journey. My PhD has been more than an academic path; in fact, it has involved an immense commitment to learn about new ideas, tools and other cultures. I am the first of my family to pursue a PhD and I hope my example inspires future generations.

Since I started the application process to pursue doctoral study, I identified two important needs for carrying out my research. The first was a need to comprehend, as much as possible, tikanga Māori (or Māori customary values and practices), as whenua (or land) represents a source of identity for Māori. The second was a need to understand the history surrounding current Māori land law. These two needs have been critical in ensuring a respectful, ethical, sympathetic and hopefully useful work.

I wish to start expressing my deepest gratitude and respect to my supervisors, Professor Carwyn Jones (Ngāti Kahungunu and Te Aitanga-a-Māhaki), Professor Dave Frame and Dr Suzi Kerr. They have convincingly taught, encouraged and guided me to become a researcher with strong critical thinking and criteria. Without their persistent help, support and patience, I could not have reached the goal of successfully finishing my $\mathrm{PhD}$ dissertation. My deepest gratitude to Suzi, in particular, who has been with me since the beginning of this project and who has supported me through critical moments of my PhD. Thank you for being the most inspiring role model.

Besides the support of my three supervisors, I would like to express my gratitude to other people who have kindly provided comments, suggestions and ideas. It has been a blessing to have this help. In advance, I would like to thank future readers for being interested in my work.

My research proposal greatly benefitted input from Corey Allan, Dr Garth Harmsworth, Dr Izi Sin, Dr Kelly Archie and Dr Tanira Kingi. I wish to thank Dr Rebecca Kiddle and Professor Richard Boast, who kindly let me participate in their classes about Māori environmental and resource management, and Māori land law.

Chapter One and Chapter Two have greatly benefitted from input from Bronwyn Bruce-Brand, Dr Bruce Small, Catherine Leining, Ceridwyn Roberts, Craig Trotter, Daniel Williams, Dr Dominic Parker, Dr Garth Harmsworth, Hayden Swann, Dr Riri Ellis and Sophie Hale. I express my gratitude to Phil Journeaux and Dr Tanira Kingi for introducing me to board members of several Māori farms. I thank Pia Pohatu for her 
assistance in the fieldwork and guidance to engage with Māori people in Tairāwhiti, the East Coast of Aotearoa New Zealand. I also express gratitude to all the interviewees for their valuable contributions, time, insights and knowledge - without their contribution this work would not have been possible. I am grateful to Dr David Fleming, Dr Garth Harmsworth, Dr Kelli Archie and Dr Tanira Kingi for their thoughts on the questionnaire design and to Johanna Knox for transcribing the interviews. I would like to recognise the opportunity given by Arturo Garcia from Econometría SA, who kindly invited me to discuss preliminary results with a group of Colombian policy makers involved in the peace process and rural public policy. Finally, my gratitude to Motu Economic and Public Policy Research Trust (Motu) for permission to include Chapter Two in my thesis.

Chapter Three and Chapter Four have greatly benefitted from input from Dr Arthur Grimes, Ben Davies, Corey Allan, Dr Dean Hyslop, Edmund Lou, Dr Dominic Parker, Dr Garth Harmsworth, Dr Levi Timar, Dr Riri Ellis, Shaan Badenhorst, Simón Borrero and Dr Zack Dorner. My special gratitude to Dr Dave Maré for his econometric advice and guidance to keep developing my coding skills in Stata. I which to thank Bethanna Jackson for inviting me to the hydrogroup meetings and to Keith Miller, Dr Martha Trodalh and Rubianca Benavidez for their assistance with ArcGIS for use of geospatial data. I am grateful for the opportunity to present preliminary results and analysis from Chapter Three at Motu seminars, the Australasian Agricultural Resource Economic Society conference and the New Zealand Association of Economists conference. Finally, I recognise the opportunity given by Julián Arévalo, Dean of the school of Economics from Universidad Externado de Colombia, who kindly invited me to present at Seminario de Avances de Investigación.

My sincere appreciation to the whānau/staff members from Motu, who have assisted greatly in conducting my $\mathrm{PhD}$ research. I am so grateful for the remarkable opportunity of being involved in several research projects. Through them, I have enriched my understanding of Climate Change public policies and the modelling work done on decisions concerning land utilisation in Aotearoa New Zealand.

I am grateful for the work from all professional staff at Te Herenga Waka - Victoria University of Wellington (VUW), in particular, thanks to Dr Polly Stupples and Dr Wokje Abrahamse for the opportunity to tutor their classes. I also extend my thanks to Barry Lewis, Ellen Anderson, Isobel Cairns, Karen Collins, Lisa Reynolds, Dr Lizzie Towl, Miranda Voke, Patricia Stein and Professor Rewi Newnha. Their understanding, support and cheerful conversations have been critical throughout my PhD. Thanks for 'writing 
spaces' like 'shut up and write' at Milk and Honey, the thesis bootcamps and 'writing to finish'. I learned, a great deal from the journeys and research of others. My warm appreciation to Dr Deborah Laurs and Dr Sara Cotterall for being active listeners and helping me to organise ideas before writing them.

Thanks to Colfuturo, Motu, Previsora Seguros and VUW for financial support. I also thank the Faculty of Science, School of Geography, Environment and Earth Science for funding attendance at conferences.

I am deeply grateful to the Yoga Centre for Higher Self and my meditation group for offering a space for stress-release and joy. My especial thanks to Andrea Llinás, Carolina Galvis, Chris Malcolm, Laura Callagham, Peter Waugh, Rosa Lucia González and Tui Parker for supporting me emotionally, physically and spiritually.

A big thank you to all my friends, especially to Amilie Bentley, Cecilia Vela, Esperanza Barrera, Hannah Griffin, Jill Fernandez, Juan David Rueda, Juan Pablo Vazquez, Kartik Nagarajan, Kate Preston, Konstantinos Michailos, Maxine Watene, Nathan Chappell, Orlando Gracia and William Henriquez for listening to my adventures. Big thanks to Norm Meehan and his family for their hospitality and the family dinners. Also thanks to Rhian Salmon for inviting me to spend time with her family and write out of Wellington. My deepest heartfelt appreciation goes to Juan Pablo Yepez. His love, humour and motivation has helped me to overcome the hurdle of completing the last stage of my PhD.

I also wish to recognise the unconditional love of my family, my dad Alfonso, my mum Margarita, my beautiful sister Paola and my stepfather Pedro. Thank you all for inspiring me to keep working, and writing this thesis. In my sister's words: "we are your biggest fans". I would not have been able to achieve all of this without their assertive words, kindness and reminders about the importance of achieving our dreams. Thanks for believing in me and giving me tools for working on this project. My gratitude to my 'broken' parts, which are almost healed. Thanks Sandra for deciding to travel to Aotearoa New Zealand and being involved in such a wonderful journey.

Thank you also to Madeleine Collinge and Shelley Dixon, professional editors who have provided proofreading services in accordance with the Editorial Advice Policy of Victoria University of Wellington. 


\section{Disclaimers}

The views and opinions expressed in this thesis reflect my personal experience and understanding of the Aotearoa New Zealand context. Any information provided does not necessarily reflect the official policy or position of any organisation, employer or company mentioned before. Assumptions made in the analysis reflect my personal position and humble understanding of the complex relationship between Māori and whenua (land). I am responsible for all opinions and any errors.

This work is based on/includes Ministry of Justice and Ministry for Primary Industries data (C) Crown Copyright - Licensed for re-use under the Creative Commons Attribution 4.0 International Licence (BY) 4.0.

\section{Publications}

Chapter Two has been previously published as:

Cortés Acosta, S. (2019). Carbon farming on Māori land: Insights on the decision-making process (Motu Note 32). Retrieved from https://motu.nz/our-work/environment-andresources/emission-mitigation/waro-project/carbon-farming-on-maori-land-insights-onthe-decision-making-process 


\section{Table of contents}

General introduction $\quad 1$

$\begin{array}{ll}\text { Chapter One. The role of Māori land governance structures to facilitate land-use decisions } \quad 7 & 7\end{array}$

$1 \quad$ Transition from a customary regime to individual title: a general context $\quad 10$

1.1 Te whenua Te iwi, the land and the people 11

$\begin{array}{lll}1.2 & \text { An era of land alienation and title individualisation } & 12\end{array}$

$\begin{array}{lll}1.3 & \text { The current Māori land law framework } & 16\end{array}$

$2 \quad$ Social arrangements of common property regimes: a conceptual framework $\quad 18$

$3 \quad$ Multiple case study approach: methodology $\quad 21$

$\begin{array}{lll}3.1 & \text { Sample and data collection } & 21\end{array}$

$\begin{array}{ll}3.2 & \text { Question guide } \\ \end{array}$

$\begin{array}{lll}3.3 & \text { Data analysis } & 23\end{array}$

$\begin{array}{llr}3.4 & \text { Study limitations } & 24\end{array}$

$4 \quad$ Results of the case studies $\quad 25$

$\begin{array}{lll}4.1 & \text { Tairāwhiti Station } & 25\end{array}$

$\begin{array}{lll}4.2 & \text { Kerikeri Station } & 32\end{array}$

$\begin{array}{lll}4.3 & \text { Pongakawa Station } & 38\end{array}$

$5 \quad$ Conclusions and lessons $\quad 44$

$\begin{array}{lll}5.1 & \text { Directions for future research } & 46\end{array}$

Chapter Two. Carbon farming on Māori freehold land: insights on decision-making processes 49

$1 \quad$ Face-to-face semi-structured interviews: methodology $\quad 52$

$\begin{array}{lll}1.1 & \text { Question guide } & 52\end{array}$

1.2 Analysis $\quad 53$

$\begin{array}{lll}1.3 & \text { Study limitations } & 53\end{array}$

$2 \quad$ Results of the interviews $\quad 53$

2.1 The nature of the decision-making process $\quad 53$

2.2 Opinions on forestry and native trees as an option for future land-use 63

$\begin{array}{lll}2.3 & \text { Opinions on carbon farming programmes } & 64\end{array}$

$3 \quad$ Conclusions $\quad 65$

$\begin{array}{lll}3.1 & \text { Directions for future research } & 67\end{array}$

Chapter Three. Land-cover choices in Aotearoa New Zealand: do Māori land governance $\begin{array}{ll}\text { structures make a difference? } & 69\end{array}$

\begin{tabular}{lll}
\hline & Decisions on land utilisation: a conceptual framework & 73
\end{tabular}

$2 \quad$ New Zealand Private Rural Land dataset $\quad 77$

$\begin{array}{lll}2.1 & \text { Dependent variables } & 79\end{array}$ 
$2.2 \quad$ Independent variables

3.1 Land-cover shares in 2012

$3.2 \quad$ Land-cover transitions 1997-2012

3.3 Econometric issues

4.1 Land-cover shares in 2012

4.2 Land-cover transitions 1997-2012

$\begin{array}{lll}5.1 & \text { Directions for future research } & 100\end{array}$

Chapter Four. Māori land governance structures and greenhouse gas emissions

$2.1 \quad$ Factual and counterfactual scenarios

2.2 Land-cover transitions in hectares

3 Simulation results 


\section{List of figures}

$\begin{array}{ll}\text { Figure 1-1 Structure of decision-making processes - Tairāwhiti station } & 27\end{array}$

Figure 1-2 Structure of decision-making processes - Kerikeri station 33

Figure 1-3 Structure of decision-making processes - Pongakawa Station 39

Figure 2-1 Historical decision-making about carbon farming $\quad 55$

Figure 3-1 Land-cover shares in 2012 by land status $\quad 80$

Figure 3-2 Land-cover shares in 2012 by Māori freehold land with or without structure 80

Figure 3-3 LUC classes by land status $\quad 85$

Figure 3-4 LUC classes by Māori freehold land with or without structure 86

Figure 3-4 Māori freehold land by Māori Land Court Districts 102

Figure 3-5 Māori freehold land with and without structure by Māori Land Court Districts 103

Figure 4-1 Long- and short-lived climate polluters and land-cover transitions 119

Figure 4-2 Changes in hectares, by scenarios - private land $\quad 127$

Figure 4-3 GHG emissions or captures, carbon dioxide equivalent, by scenarios - private land 128

Figure 4-4 GHG emissions or captures, warming equivalent, by scenarios -private land 130

Figure 4-5 Changes in hectares, by scenarios - Māori freehold land 131

Figure 4-6 GHG emissions or captures, carbon dioxide equivalent, by scenarios - Māori freehold land 132

Figure 4-7 GHG emissions or captures, warming equivalent, by scenarios - Māori freehold land 133

Figure A3-1 Māori freehold land with and without structure by Māori Land Court Districts: North Island 165

Figure A3-2 Māori freehold land with and without structure by Māori Land Court Districts: South Island 166 


\section{List of tables}

$\begin{array}{lr}\text { Table 1-1 Interviews sample } & 23\end{array}$

$\begin{array}{lr}\text { Table 3-1 Data sources for the NZPRL dataset } & 104\end{array}$

Table 3-2 Summary statistics for the NZPRL dataset 105

Table 3-3 Concordances between land-cover classes and land-cover categories 106

Table 3-4 Transition matrix: land-cover transitions 1997 to 2012 (pixels and shares) 107

$\begin{array}{lr}\text { Table 3-5 Māori freehold land by Māori Land Court districts } & 108\end{array}$

Table 3-6 Average marginal effects (AME) for land-cover shares 2012 - Māori freehold land relative to general land

Table 3-7 AME for land-cover shares 2012 - Māori freehold land with structure relative to Māori freehold land without structure

Table 3-8 AME for land-cover transitions 1997-2012 - Māori freehold land relative to general land

Table 3-9 AME for land-cover transitions 1997-2012 - Māori freehold land with structure relative to Māori freehold land without structure

Table 4-1 Description of scenarios for simulations

Table 4-2 Explanation of terms used in GHG emission estimates

Table 4-3 Emissions estimates for land-cover transitions from 1997 to 2012 -private land

Table 4-4 Emissions estimates for land-cover transitions from 1997 to 2012 - Māori freehold land

Table A3-1 Coefficient estimates for land-cover shares 2012 - Māori freehold land relative to general land

Table A3-2 Coefficient estimates for land-cover shares 2012 - Māori freehold land with structure relative to Māori freehold land without structure

Table A3-3 Coefficient estimates for land-cover transitions 1997-2012 - Māori freehold land relative to general land

Table A3-4 Coefficient estimates for land-cover transitions 1997-2012 - Māori freehold land with structure relative to Māori freehold land without structure

Table A4-1 Average predicted probability of transition (probability estimates) 1997 - 2012, by scenarios

Table A4-2 Land-cover transitions 1997 - 2012 in hectares, by scenarios

Table A4-3 Hectares and emissions estimated, by scenarios -private land 175

Table A4-4 Hectares and emissions estimated, by scenarios - Māori freehold land 


\section{General introduction}

"Pēnā ka haere tonu, à te wā ka taea, ka mau - You will get there if you just keep going" Whina Cooper

Anthropogenic activities on the land have interfered with the earth's natural climate system and have caused negative externalities such as declining water quality or greenhouse gas (GHG) emissions. The identification of drivers for land utilisation and management can help to create public policies that aim to reduce the environmental impacts of land use and land cover. In this study, I use a mixed-methods approach to explore how Māori land governance structures influence decisions for land utilisation and hence GHG emissions associated with rural activities on Māori freehold land.

This dissertation is the result of multidisciplinary research that involves elements of Aotearoa New Zealand history, Māori land law, economics, geography and climate change science. Furthermore, this document reflects a view of the current Aotearoa New Zealand context through the eyes of a Colombian woman, who bases her interpretations on readings, analysis of documents of the Waitangi Tribunal, conversations with academics and Māori people, and experience gained working at Motu Public Policy Research Trust (Motu) and Victoria University of Wellington.

Although I do not pretend to make a comparison between Aotearoa New Zealand and Colombia, it is noteworthy that I came to this topic motivated by a personal interest in learning about a rural development model. In the future, I would like to contribute to my country with potential solutions to different conflicts Colombia faces in its rural areas. For instance, rural Colombia has significant inequalities in income and land ownership (Organisation for Economic Co-operation and Development, 2015; Ibañez \& Muñoz, 2010) and inefficient land utilisation patterns. Therefore, some agricultural activities have low productivity and hence poor GHG efficiency. ${ }^{1}$ I strongly believe that Aotearoa New Zealand and the Māori community have developed models that can be used as

\footnotetext{
${ }^{1}$ Ocampo (2014) argues that low productivity and lack of competitiveness in the cropping sector has motivated land-use transitions from cereals and oilseeds to livestock and pasture since the late 1990s. Balcázar and Rodríguez (2013) estimate that, in 2012, the land area suitable for cropping was about 22-million hectares and the land suitable for livestock and pastoral activities was about 19-million hectares. However, only 5-million hectares were used for cropping, while around 40-million hectares were used in grazing livestock.
} 
examples for novel solutions to improve environmental and socio-economic outcomes in rural Colombia.

In Aotearoa New Zealand, during the 19th century, the Crown used a series of legislative mechanisms to facilitate the alienation of land from Māori. The Māori customary regime was seriously altered, and land titles were individualised to facilitate land transaction and settlement. As a consequence of this individualisation process, general land and Māori freehold land became the main land statuses of 'private land' in the country. I refer to these two land statuses as private land to differentiate them from Crown land. ${ }^{2}$

Māori freehold land, under collective 'ownership', represents 5\% of the territory in Aotearoa New Zealand (Harmsworth, 2018), and reflects that its title has been determined by the Native/Māori Land Court. Thus, this land status is subject to a distinct statutory regime, which is characterised by a tenure regime that is ultimately based on the customary regime and ancestral connections. However, as a result of the individualisation process, Māori freehold land has fragmented titles and multiple owners, which make the administration and decision-making processes complex.

Today, matters regarding Māori freehold land are regulated under the Te Ture Whenua Māori Act 1993 (TTWM), which promotes the retention, control, use and development of this land by its landowners. The TTWM also provides a range of legal entities, including the two Māori land governance structures examined in this thesis, Māori incorporations and Ahu Whenua trusts, which were designed to facilitate decision-making and to administer the land and assets on behalf of the owners. ${ }^{3}$ I focus on these two governance structures because these are the most commonly used, and they are used for commercial purposes. Additionally, the information available about

2 Crown land is land in public ownership (including land managed by the Department of Conservation). General land can be understood as privately owned land not subject to the special restrictions of either Māori freehold land or Crown land; this land can be owned by Māori just like any other landowner. Often land returned to Māori in treaty settlements is general land.

${ }^{3}$ I recognise that Māori incorporations and Ahu Whenua trusts have differences in terms of the legal framework and origins, but based on my experience in the fieldwork and documented in Chapter One and Chapter Two (acknowledging that I talked to a small sample of Māori farms), I have not found essential differences in the way that these structures affect decisions. Ultimately, both structures have a board that makes decisions on behalf of landowners and works with a group of people, led by the farm manager, to optimise the enterprise's performance. 
these structures facilitates econometric analysis. I estimate that Māori land governance structures administer $83 \%$ of Māori freehold land. 4

While there are good reasons to believe that Māori land governance structures promote decisions on land utilisation and management, no other study has explored this relationship through econometric analysis. The overarching question that motivates my work is: do Māori land governance structures influence decisions on land utilisation and hence GHG emissions associated with rural activities?

I explore the relationship between governance structures and decisions on land utilisation. I aim with my analysis to support intuition and give an idea of the scale of these relationships. This document is structured in four chapters, as follows:

In Chapter One, I explore how Māori land governance structures help landowners to make decisions on land utilisation and management. I start this chapter outlining the complex historical context that surrounds the creation of Māori freehold land title and the need for Māori land governance structures to address challenges associated with title individualisation, such as fragmented titles and multiple owners. Next, I document three case studies of Māori land governance structures involved in agribusiness, including one Māori incorporation, one Ahu Whenua trust and one Ahu Whenua trust administered by Te Tumu Paeroa. I conducted face-to-face semi-structured interviews with board members from these three case studies. I asked questions about how decisions are made, preferences and strategic goals that influence decisions, and factors that facilitate or inhibit decisions.

These three case studies exemplify how Māori land governance structures can work in practice and the different factors that influence decisions and the structure of the decision-making process. The structures studied have made 'successful' decisions about land utilisation, by balancing landowners' interests with optimal agribusiness operation and performance. This success not only depends on the legal constitution of the governance structure, but also on processes that are highly variable due to cultural and social values, and the capability of board members to reach decisions. The structure of the decision-making process can be separated into two levels: the governance of the land and the operation of the enterprise.

In Chapter Two, I explore the nature of the decision-making process around choosing carbon farming, an opportunity to receive carbon credits from reforestation or

\footnotetext{
${ }^{4}$ As I discuss in footnote 56 on page 81 , this information differs by sources.
} 
afforestation. I conducted face-to-face semi-structured interviews with a small group of Māori landowners who have been involved in the decision-making process on their land in Tairāwhiti, on the East Cape of Aotearoa New Zealand. I asked questions about the strengths and weaknesses of the current agreements, and landowners' opinions on carbon farming programmes, with an emphasis on the New Zealand Emissions Trading Scheme (NZ ETS).

Their experience can be summarised in terms of two central decisions: switching to forestry and joining the NZ ETS. In their experience, forestry has provided an economic opportunity to access long-term capital. In contrast, carbon farming is a relatively new experience, considered a bonus that could provide revenue in the short term, before income from harvest of timber, or potentially in the long term if areas are allowed to regenerate to native forest, where the land block is eligible for joining the NZ ETS. Because the carbon cycle and schemes based on this cycle are new concepts in Te Ao Māori, or the Māori worldview, there is a need for well-considered engagement and provision of trustworthy and credible information about how to achieve carbon farming.

In Chapter Three, I measure the relationship between Māori freehold land and land utilisation (or land-cover choices due to data restrictions); and, within Māori freehold land, the relationship between Māori land governance structures and land-cover choices. I use maximum likelihood methods to explore four questions: was Māori freehold land less likely to be used in capital intensive activities in 2012 in comparison with general land, after controlling for land characteristics? Did Māori land governance structures influence this likelihood? Was Māori freehold land less likely than general land to make an active transition between 1997 and 2012? Did Māori land governance structures influence these transitions? By active transition, I refer to a positive landcover change that involved any sort of investment.

For the econometric analysis, I created the New Zealand Private Rural Land (NZPRL) dataset, which contains panel information of rural land-cover (including horticulture, pasture, forestry, scrub or indigenous forest) and cross-sectional characteristics of the land. My results suggest that, in 2012, on average, relative to general land, Māori freehold land was more likely to be in forestry, scrub or indigenous forest. Within Māori freehold land, I found a positive relationship between Māori land governance structures and forestry, but not scrub or indigenous forest. In terms of land-cover transitions, my results indicate that, relative to general land, on average Māori freehold land was less likely to make an active land-cover transition between 1997 and 2012. Within Māori 
freehold land, I found a positive relationship between having Māori land governance structures in place and transitions from pasture into forestry or conversions from scrub into forestry. The results suggest a preference towards forestry when the land is Māori freehold land and has a structure in place.

In Chapter Four, I build on the econometric analysis and explore the environmental implications of three land-cover transitions - pasture to forestry, pasture to scrub and forestry to pasture, between 1997 and 2012. I use hypothetical scenarios to simulate different probabilities of land-cover transitions and estimated indicative GHG emissions, in terms of both carbon dioxide equivalent and warming equivalent. The hypothetical scenarios are based on: what would the implications be if private land was utilised in the same way as Māori freehold land with structure? What would the implications be if all Māori freehold land was utilised in the same way as Māori freehold land with structure? My results illustrate that Māori freehold land governance structures would lead to an increase by $27 \%$ of the overall tonnes of carbon dioxide equivalent sequestered, relative to the actual sequestration calculated. This is mainly because less land would have converted into new pasture. In terms of the GHGs emissions implications, the results suggest that the current way of counting GHGs leads to a much lower estimate of the contribution in reductions to the impact of warming. 



\section{Chapter One. The role of Māori land governance structures to facilitate land-use decisions}

In this chapter, I aim to provide a general overview of the complex context that gave space to the creation of the Māori land governance structures. The overarching question that motivates this chapter is: how do Māori land governance structures help landowners to make decisions on land utilisation and management? I conducted face-toface semi-structured interviews with trustees and committee members from three Māori land governance structures involved in agribusiness, including one Māori incorporation, one Ahu Whenua trust and one Ahu Whenua trust administered by Te Tumu Paeroa. The three case studies documented in this chapter exemplify how these structures can work in practice and the different factors that influence decisions and the structure of the decision-making process.

During the 19th century, the Crown in Aotearoa New Zealand used a series of legislative mechanisms to facilitate the alienation of land from Māori (Boast, 2008). The Māori customary regime was seriously altered and land titles were individualised to facilitate land transaction and settlement. The conversion from a customary regime into a fee simple (or freehold title system) revealed difficulties in reconciling the 'new' system with the customary regime. Under the customary regime, land is held in accordance with tikanga Māori or Māori customary values and practices ${ }^{5}$ and represents a source of identity (Durie, 1998), while in the 'new' land tenure system created by the Crown, land is seen in terms of market potential and commercial interests.

The freehold title system not only resulted in the alienation of the land, undermined tribal authority, and imposed complex ownership arrangements (Belgrave, Deason, \& Young, 2004), but also created the two main land statuses: general land and Māori freehold land. General land can be understood as privately owned land that may be owned by Māori or any other New Zealander, and it is not subject to the special restrictions of Māori freehold land. Māori freehold land, under collective 'ownership', denotes a land title determined by the Native/Māori Land Court. This land status is

\footnotetext{
${ }^{5}$ Jones (2014) notes that tikanga is not equivalent to customary law. Tikanga operates in all aspects of Māori life and comprises cultural, spiritual and practical aspects which are beyond a set of rules that apply to distinct areas of social life or a strictly legal domain (p. 190).
} 
subject to the distinct statutory regime based on customary regime and ancestral connections. ${ }^{6}$

Today, Māori freehold land is primarily governed by the Te Ture Whenua Māori Act 1993 (TTWM). The TTWM has roots in the relationship of Māori with the land, the transition of customary land to an individual title, and different attempts to address challenges associated with fragmented titles and multiple owners. It has been estimated that Māori freehold land is about 5.0\% of Aotearoa New Zealand's 26.8 million hectares of total land area (Harmsworth, 2018). ${ }^{7}$

For Māori, attitudes towards land are multidimensional and still deeply influenced by mātauranga Māori (Māori knowledge systems) (Harmsworth \& Awatere, 2013; Mead, 2016; Marsden, 2003). The political and legal processes that preceded the issue of the TTWM demonstrated that Māori saw recognition of land as a basis of identity (Durie, 1999; Mead, 2016). Additionally, the pressure to develop the land with commercial interests motivated a 'new role' for the land as a sustainable economic base for themselves. Therefore, the TTWM focuses on retention alongside utilisation and recognises land as tāonga tuku iho - a treasure that connects current generations with their ancestors and future generations. Then, decisions on land use may involve intergenerational considerations, collective action and a bundle of property rights.

Because Māori freehold land has a complex ownership arrangement with a multiple ownership structure and fragmented titles (Belgrave, Deason, \& Young, 2004) different alternatives have been explored (that is, including incorporating land blocks and vesting

\footnotetext{
${ }^{6}$ Apart from these two main statuses, the TTWM, in Part 6, defines four more statuses: 1. Māori Customary land is land held by Māori in accordance with tikanga Māori; 2. general land owned by Māori is land, other than Māori freehold land, that has been alienated from the Crown for a subsisting estate in fee simple, while that estate is beneficially owned by a Māori or by a group of people of whom a majority are Māori; 3. Crown land is land, other than Māori customary land and Crown land reserved for Māori, that has not been alienated from the Crown for a subsisting estate in fee simple; and 4. Crown land reserved for Māori is land, other than Maori customary land, that has not been alienated from the Crown for a subsisting estate in fee simple but is set aside or reserved for the use or benefit of Māori.

7 The total area of Māori freehold land differs by sources. Te Puni Kōkiri (2014b) estimates that Māori freehold land varies between 1.43 million and 1.77 million hectares, while Kingi (2008a) suggests that Māori freehold land is about 5.6\% of New Zealand's total land area of 26.9 million hectares.
} 
the land on trustees) to facilitate decisions throughout Aotearoa New Zealand. Nowadays, the TTWM provides a scheme of six legal entities and defines and outlines their operation. These legal entities are Māori incorporations and five different types of trusts. ${ }^{8}$ In this thesis, I concentrate my attention on Ahu Whenua trusts and Māori incorporations (hereafter, Māori land governance structures). I concentrate on these two legal entities for being the most commonly used to facilitate decisions and administer the land on behalf of the owners, mainly for commercial purposes.

It has been broadly discussed and accepted that the Māori land governance structures help Māori to face challenges created after the land title process (see for example Kingi, 2008a; Funk 2009; Ministry of Agriculture and Forestry, 2011). This is because the governance structures facilitate decisions by reducing decision costs (that is, any costs associated with the decision-making process, such as the time taken to agree with other landowners).

The three case studies documented in this chapter have enhanced my understanding of decision-making processes, preferences and strategic goals that influence decisions, and factors that facilitate or inhibit decisions.

The three case studies are examples of the role that a governance structure can play to facilitate decisions on the development and use of blocks of Māori freehold land with commercial purposes. The revenues from a specific enterprise can be used to sponsor activities for the benefit of the whole community or be invested back into the land to protect an area that is considered tapu (sacred). When board members and the farm manager are making decisions, they might consider social, economic, environmental and cultural interests.

I have learned that several actors (for example, board members or farm managers) may be involved at different stages of the decision-making process and their

\footnotetext{
${ }^{8}$ Apart from Ahu whenua trusts, which are the most commercially focused, the TTWM provides four more types of trusts: 1 . Whenua tōpū trusts promote and facilitate the use and administration of the land in the interest of iwi or hapū; 2 . Kaitiaki trusts facilitate the administration of interests in Māori freehold land or general land, shares in a Māori incorporation, or personal property, to which any person under disability is beneficially entitled; 3 . Whānau trusts allow families to bring together all family interests in a piece of land, helping them to administrate the land without expectations of individual land interests or dividends; and 4. Pūtea trusts deal with any minimal value of the interests or share in Māori freehold land or general land owned by Māori (Department for Courts, 2001; McPhail, 2004).
} 
participation depends on the type of decision. Understanding how bundles of rights (Agrawal, 2001; Schlager \& Ostrom, 1992) have been allocated between different actors is important to know the extent of their participation in the decision-making process and what type of decisions they are able to make.

Another lesson is that there are two types of decisions: at the governance level and at the operational level. The difference between these two is critical for the success of the enterprise. At the governance level, decisions concentrate on land administration or major situations that can compromise the well-being of current and future generations. At the operational level, decisions concentrate on the management of a specific enterprise that takes place on the land. I have noticed that board members are interested in bringing in expertise by hiring experts in the business or enterprise.

Future research would be required to determine how representative the results found in this chapter are of those in the broader Māori community regarding decisionmaking processes, preferences and strategic goals that influence decisions, and factors that facilitate or inhibit decisions.

The remainder of the chapter is structured as follows. Section 1 presents a general context about the transition from a customary regime to individual title. Section 2 presents the conceptual framework used for analysing social arrangements of common property regimes. Section 3 presents the methodology used for the multiple case study approach. Section 4 presents the results of the case studies. Section 5 concludes the chapter.

\section{Transition from a customary regime to individual title: a general context}

This section lays out my understanding of the relationship between Māori and the land, and how this relationship has been altered by historical experiences between Māori and the Crown. I also consider the role of Māori land governance structures - Māori incorporations and Ahu Whenua trusts, two legal entities with roots in different parts of Aotearoa New Zealand history. These two structures were created by the Crown, and adopted by Māori landowners, as an attempt to address the problems derived from title individualisation (Boast, 2004). 


\subsection{Te whenua Te iwi, the land and the people}

While many aspects of Māori culture are integrated into mainstream culture in Aotearoa New Zealand, Māori culture remains distinct in several ways. Before European arrival in Aotearoa New Zealand, the association with the land was shaped under the Mãori belief that people belong to the land rather than owning it (Mead, 2016). As pointed out by Mason Durie (2010) the foundation upon which indigenous people understand the world is constituted by relationships between people and the natural environment, between organic and inorganic material, between tangible and intangible dimensions, and between the past and the future.

For Māori, the relationship between people and land comes from an ancestral connection based on customary practices, protocols and values. Land is a source of identity for Māori, as they see themselves as tangata whenua or the people of the land. Whenua is the word for land in Te Reo Māori (Māori language). As Mead (2016) states:

whenua carries a wide range of meanings. Whenua, as placenta, sustains life and the connection between the foetus and the placenta is through the umbilical cord. This fact of life is a metaphor for whenua, as land, and is the basis for the high value placed on land (p.285).

Under a Māori customary regime, rights of occupation and use were determined collectively by Māori tribal authorities, subdivided into whānau, hapū and iwi (family, sub-tribe and tribe). As observed by Eddie Durie (1987):

in the beginning land was not something that could be owned or traded. Maoris did not seek to own or possess anything, but to belong. One belonged to a family that belonged to a hapū that belonged to a tribe. One did not own land. One belonged to the land (p. 78).

The Māori customary regime and association to land led to collectively held rights of occupation, access and use over land without claiming ownership (M. Durie, 1998; Kingi, 2008a; Bennion, 2009). The rights to land were evidenced through occupation by establishing kāinga (settlement) and cultivation, but also through the use of resources for the sustainability and survival of the settlement. Association with the land was predominantly recognised by an ancestral connection based on historical occupation (ahikāroa) or spiritual connection with the land, for example, birth or death of their ancestors. Given this ancestral connection with a specific land or area, the association 
with the land could be retained even when rights over the land were lost (Waitangi Tribunal, 2003). Under the lens of the common property conceptual framework, the Māori customary regime distinguished among diverse bundles of rights that might be held by the users of the land and other resources (Schlager \& Ostrom, 1992).

Although the Crown has altered the customary regime, attitudes towards land are still profoundly influenced by mātauranga Māori (Māori knowledge system) (Harmsworth \& Awatere, 2013; Mead, 2016; Marsden, 2003). Mātauranga Māori provides the basis for Te Ao Māori (Māori world view) and Māori values through which Māori experience and interpret their environment and determine their attitudes towards land (Harmsworth \& Awatere, 2013; Phillips \& Hulme, 1987; Mead, 2016; Marsden, 2003). Harmsworth and Awatere (2013) explain that Māori values underline important Māori environmental concepts guiding the relationship and responsibilities Māori have for the environment. Examples of these Māori values are:

- whakapapa - genealogical connection

- mana whenua - authority over land and resources

- whānaungatanga - family connections

- kaitiakitanga - guardianship or stewardship.

Māori environmental concepts include:

- mana - having authority or control over the management of a resource

- taonga tuku iho - intergenerational protection of treasure resources

- te ao turoa - intergenerational resource sustainability.

Decision drivers regarding the use of the land can be associated with interdependency and intergenerational equity. Interdependency can be seen as a reciprocal relationship between people and the land, and comprises manaaki whenua (caring for the land) and manaaki tangata (caring for people) (Harmsworth \& Awatere, 2013). Intergenerational equity can be seen as a concern for resource sustainability and protection of the land across generations. With these decision drivers in place, land is passed from one generation to the next in as good a condition as it was received.

\subsection{An era of land alienation and title individualisation}

From the 1860s, the Crown drastically altered the Māori customary regime to facilitate the trading of land for European settlement purposes. An ownership arrangement with individual title recording owners and shareholders replaced the customary regime. 
Although some land blocks remained under Māori ownership (today known as Māori freehold land), this individualisation undermined tribal authority and affected the social cohesion between whānau, hapū and iwi.

The Crown enforced a range of legal mechanisms to alienate land from Māori and individualise the property rights of the land without reference to the wider community. ${ }^{9}$ The main mechanisms used were land confiscation, Crown land purchases, and alienation facilitated by the Native Land Court (Boast, 2008; Bennion, 2009). ${ }^{10}$ The Native Land Court was established to stipulate who held the rights on customary land, and had the authority to convert customary lands into fee simple. ${ }^{11}$ Land was surveyed, divided up into blocks of varying sizes, and lists of 'owners' were drawn up and allocated with shares (Mead, 2016). As a result, two parallel ownership arrangements took place: European land (today known as general land) and Māori freehold land. Since then, Māori freehold land has evolved into a complex multiple ownership structure with fragmented titles and multiple interests (Kingi, 2008a; Waitangi Tribunal, 2008). ${ }^{12}$

During the 20th century, with a paternalistic perspective, the Crown was deeply involved in the administration and management of Māori freehold land with commercial purposes. Before the Second World War, policies regarding Māori land development relied on a process of amalgamation and incorporation, as an attempt to consolidate

\footnotetext{
${ }^{9}$ It is common to find that 'community' refers to iwi (tribe), hapū (sub-tribe) and whānau (family) as a group, but given the current New Zealand context, I use the term 'community' to refer to the group of landowners from a landblock and their descendants.

${ }^{10}$ Land confiscation was a coercive expropriation of customary land by statutory fiat and was a way to individualise the land that was under Māori customary tenure and make it recognisable under English Common Law (Boast, 2008). The legal mechanisms enforced by the Crown also comprised several Public Works Acts. The analysis of these mechanisms is beyond the scope of this research: for a further analysis on these mechanisms see Marr (1997).

${ }^{11}$ To claim rights over customary land, the Native Land Court used three take (foundations): take tuku (gift), take ōhāki (deathbed deposition) and take raupatu (conquest) (Sinclair, 1977).

12 The legislation in the 1860s mandated that all descendants from the former 'owners' had an equal right to the land. For that reason, land titles allocated to some Māori owners were handed down through successive generations. Additionally, descendants now have an absolute right of ownership to the land interest of both parents. Registered owners in the last few generations have then exponentially increased (Kingi, 2009).
} 
land blocks into economic units and simplify ownership (Belgrave et al., 2004). ${ }^{13}$ After the mid-20th century, the Māori Affairs Act 1953 and its amendments led to an era of title reforms and schemes for administering Māori freehold land. Furthermore, policies were mainly implemented through the Māori Land Court (formerly the Native Land Court), the Department of the Māori Affairs, ${ }^{14}$ and the Māori Trustee ${ }^{15}$ (Fleras \& Spoonley, 1999; Belgrave et al., 2004; Waitangi Tribunal, 2016).

The Māori Affairs Act 1953, for example, introduced a leasing regime, set out reforms for the operation of Māori incorporations and created a system of trusts, known as 438 trusts. ${ }^{16}$ This Act also conferred the Māori Land Court with special powers to 1) appoint the Māori trustee as an agent to dispose of unproductive land; 2) allow others apart from landowners to develop a specific Māori land block, when it was proved that it was

13 The Incorporations system was established under the Native Land Court Act 1894. Given that this system facilitated the amalgamation of land titles into groups, Sir Āpirana Ngata recognised incorporations as an attempt to revert the individualisation of the land titles and emulate the former regime of collective ownership, with one important difference: the administration of the land was centralised in a group of committee members (M. Durie, 1999; Kingi, 2008a; White, 1997).

${ }^{14}$ Although the roots for the Department of Māori Affairs can be traced back to former agencies created in the 1800s, it was formally established in 1947 (Fleras \& Spoonley, 1999). This government body was charged with implementing and running initiatives regarding Māori policy and land development, vocational training, welfare, and housing (M. Durie, 1999). Initially, it was constituted under the philosophy of supporting tribal leaders and encouraging collective strategies with tribal aspirations for developing their land (Fleras \& Spoonley, 1999).

15 The position of the Māori Trustee was formerly established at the beginning of the 20th century under the Native Trustee Act 1920. It was originally created to support the management and productivity of Māori freehold land. The Māori Trustee was established under the Māori Trustee Act 1953 and later replaced by the Māori Trustee Amendment Act 2009. According to the more recent Act, the Māori Trustee has the power to undertake or continue any business or activity or enter into any transaction.

16 Incorporations were provided with special provisions for the sale and purchase of Māori freehold land within the incorporation. Conversely, the 438 trusts allowed land to be vested in trustees, often the Māori Trustee, who had the power to administer the trust property for the benefit of Māori or their descendants (Waitangi Tribunal, 2016). The introduction of 438 trusts of the Māori Affairs Act 1953 were the basis for the creation of the other statutory trusts in the Te Ture Whenua Māori Act 1993. Today, 438 trusts are known as Ahu Whenua trusts. 
fertile and was not being put to 'good use', and 3) establish an incorporation over any block of Māori freehold land with three or more owners with the intent to occupy and use the land for agricultural, pastoral or timber activities.

The implementation of the reforms introduced in the Māori Affairs Act 1953 and its amendments was not an easy task for the Crown. By the end of the 20th century, Māori opposition was vocal and well organised, demanding the return of unjustly alienated land and the retention of land in Māori ownership according to tikanga Māori. As described by Jones (2014) tikanga is a Māori values-based system which:

Describes the right or correct way of doing things within Māori society.

It is a system comprised of practices, principles, processes and procedures, and traditional knowledge. It encompasses Māori law but also includes ritual, customs, spiritual and socio-political dimensions that go well beyond the legal domain (p. 189).

The Māori opposition also challenged the Crown's assumption that economic development of Māori freehold land alone would bring well-being to Māori. For the first time, the Crown was forced to recognise the cultural value of the land for Māori and acknowledge that economic development of the land was still significant, but not the only priority. As a result, the emphasis on retention and cultural value became a critical aspect in the current Māori land law framework, defined under the TTWM (Durie, 1998; Belgrave et al., 2004).

In 1989 the Department of Māori Affairs was disestablished and different bodies took responsibility for different roles and functions with Māori freehold land. At the government level, today these bodies are Te Puni Kōkiri, the Māori Land Court, ${ }^{17}$ and Te Tumu Paeroa. Led by the Māori Trustee, the role of Te Tumu Paeroa is to support landowners in protecting and enhancing their land. ${ }^{18}$

17 Today, the Māori Land Court (Te Kooti Whenua Māori) promotes and assists in the retention of Māori freehold land in the hands of the owners. The Court is also responsible for adjudicating matters relating to the effective use, management, and development, by or on behalf of the owners or beneficiaries. Additionally, the Court is in charge of maintaining the repository of Māori freehold land information, including records that date back to its establishment as the Native Land Court in 1862.

${ }_{18}$ Te Tumu Paeroa was established in 2013 to support the Māori Trustee in their duties. This body looks after an estimated 7\% of Māori freehold land on behalf of about 100,000 owners. 


\subsection{The current Māori land law framework}

The current Māori land law framework is regulated by the TTWM, under the principle that whenua (land) is taonga tuku iho (inherited treasure), connecting the current generation with their ancestors and generations come. The TTWM recognises that Māori cultural values influence Māori behaviour and relationships with the land, driving decisions relating to collaboration, investment, diversification and management of Māori freehold land. The TTWM also recognises several different land uses, not only commercial use. ${ }^{19}$

Rather than facilitating alienation, the TTWM focuses on retention alongside utilisation. As established in its preamble, the TTWM promotes the retention, use, development and control of Māori freehold land in the hands of its owners, their whānau and their hapū. To meet these objectives, the TTWM sets stringent rules that restrict the alienation of Māori freehold land, including sales or leasing (Durie 1998).

Moreover, to administer and facilitate decisions, the TTWM provides a scheme for the Māori land governance structures. These structures have become an important body to overcome absentee ownership and title fragmentation. They have been used as a vehicle for attempts to revert to collective ownership, but they cannot be easily compared with any 'institutions' observed under the customary regime (Kingi, 2008a).

\subsubsection{Māori land governance structures and their role in decisions}

As previously mentioned, the Māori land governance structures considered in this thesis are Ahu Whenua trusts and Māori incorporations. Ahu Whenua trusts work like a fiduciary relationship that is constituted exclusively by the Māori Land Court. Each trust requires land vested in the trust to be trust property, with an appointed trustee who has control of the property, ${ }^{20}$ and beneficiary or beneficiaries (landowners). A Māori incorporation works as a company and the Māori Land Court issues an order of

19 In April 2016, the Te Ture Whenua Māori Bill 2016 was introduced in the House of Representatives to further reform Māori land law. This Bill comprises significant reforms for Māori land governance structures. Analysis of proposed reforms is beyond the scope of this research: for further commentary, see Harvey (2018).

20 The essence of an Ahu whenua trust is that the assets under this governance structure are held by an individual or individual for the benefit of others and the Māori Land Court may appoint one or more trustees for each trust constituted. 
incorporation of one or more blocks of Māori freehold land. Additionally, a Māori incorporation can acquire any type of land, including general land. One difference between these two structures is that in an Ahu Whenua trust, landowners retain direct ownership interest in the land itself, whereas in a Māori incorporation, landowners become shareholders of the land.

Each Ahu Whenua trust or Māori incorporation has a board of trustees or a committee of management, respectively. Trustees or committee members (hereafter, the board or board members) manage the land or assets on behalf of landowners. The board members are selected democratically and tend to be landowners. The board may follow the Trust Order or the Māori incorporation constitution, which set out any power and responsibilities when administering the land or interest in the land.

The legal constitution of the governance structure is a separate issue to the governance capability of board members. Each structure is legally constituted by the Māori Land Court, while the success of these boards relies on the capability and experience in governance and management of board members. Moreover, there is an ongoing necessity to build governance and management experience among the board members to assist them to make informed decisions (Harmsworth, Tahi, \& Insley, 2010).

In a work developed with a network of 29 Māori farms, West, Journeaux, Wakelin, and Kingi (2016) identify critical characteristics to assist the capacity to increase farm productivity while reducing Greenhouse Gas (GHG) emissions. They conclude that the capability of governance and management influence investment decisions and farm performance.

Additionally, maintaining traditional values and cultural identity is critical in retaining owners' support for development initiatives (Kingi, 2008a). It is expected that decisions of the board members reflect landowners' interests (Kingi, 2008b). Often, these interests are multidimensional and connect economic, social and environmental aspirations (West et al., 2016; Dewes, Walzl, \& Martin, 2011; Cortés Acosta et al., 2019). The behaviour of the board and decisions of Māori land governance structures involved in agribusiness are influenced by cultural constructs, which affect decisions relating to investment, collaboration and diversification (Kingi, 2013).

Māori land governance structures are often commercially successful, but also responsible for retaining Māori freehold land for the benefit of future generations (Harvey, 2018). In fact, successful management of Māori incorporations requires a 
balance between operational factors, cultural importance, financial considerations, physical matters, political involvement and social contribution (White, 1997).

\section{Social arrangements of common property regimes: a conceptual framework}

Property rights and institutions are among the most effective mechanisms for incentivising agents to produce, maintain or improve assets, or to encourage investment. ${ }^{21}$ 'Property rights' can be understood as "the de jure and de facto rights of individuals or group of individuals to a flow of benefits from assets, with at least a partial right to exclude others" (Grafton, 2000, p. 504). 'Institutions' can be understood as "customs and rules that provide a set of incentives and disincentives for individuals" (North, 1986, p. 231). Property rights and institutions can both help to define who has the authority to make decisions related to a specific resource and determine who receives the benefits or bears the costs of these decisions.

In the case of common-pool resources (CPR) - characterised by rivalry and difficulty of exclusion (Ostrom, 1999; Ostrom \& Hess, 2007) - clearly defined property rights can help to overcome potential externalities that arise from free and open access to these. ${ }^{22}$ In the context of my analysis, it is likely that some of the resources from a block of Māori freehold land are CPR (for example, pastures or indigenous forest). ${ }^{23}$ Following Ostrom

21 The importance of property rights and institutions for economic growth and development has been widely researched (Besley, 1995; Commons, 1974; Deininger \& Feder, 2001; Libecap, 1989; North, 1986, 1990; Ostrom, 1990).

22 In 1954, Gordon was the first author to lay out the potential externalities regarding commonpool problems by saying "everybody's property is nobody's property" (p. 135). Later on, Hardin (1968) discussed the "tragedy of the commons" by using a "pasture open to all" as an example to analyse the consequences of the rationale of herders whose benefits increased when adding one more animal to the herd up to the point of overgrazing. It is important to note that "tragedy of the commons" is not a synonym of "common property". For further discussion see Frischmann, Marciano, and Ramello (2019).

${ }^{23}$ Kingi (2004) mentions that under the customary regime not every member of the community had an equal right to use, occupy or dispose of land. Access to and use of land resources was ratified by tribal opinion, meaning that this regime was not a synonym for "open access" or "free 
(1990), CPR denotes a natural or human-made 'resource system' (such as a dairy farm) that generates flows of usable 'resource units' (such as milk solids per hectare) over time. Given that in a CPR the benefits consumed by one individual subtract from the benefits available to others, a dairy farm can limit the use of the land for other activities (for example, using the land for papakāinga or housing).

The theoretical debate about the allocation of property rights has been at the core of debates surrounding the efficient use of resources and solutions to deal with the tragedy of the commons. ${ }^{24}$ An efficient property rights structure has three main characteristics: 1) exclusivity - all benefits and costs accumulated as a result of owning and using the resources should gather to the owner, and only the owner, either directly or indirectly by sale to others; 2) transferability - all property rights should be transferable from one owner to another in a voluntary exchange; and 3) enforceability - property rights should be secure from occupation or invasion of others (Tietenberg \& Lewis, 2014).

However, when the resources are CPR, alternative layers of property rights may require consideration (Agrawal, 2001). By comparing bundles of rights associated with positions - owners, proprietors, claimants, and authorised users, Schlager and Ostrom (1992) separate property rights into operational level property rights (that is, access and withdrawal) and collective-choice property rights (i.e. management, exclusion and alienation). ${ }^{25}$ As is shown in the following section, board members have a significant

access" to this resource. Once rights were allocated to an individual or a group, these rights were acknowledged and respected.

${ }^{24}$ Some theorists have clarified that common property "refers to a distribution of property rights in resources in which a number of owners are co-equal in their rights to use the resource" (CiriacyWantrup \& Bishop, 1975, p. 714). However, the interchangeable use of terms such as 'open-access resources', 'collective-action problems' and 'common-property resources' is often seen in economics literature in the 1950s. This led the idea that privatisation or centralisation are the only two 'solutions' for facing the tragedy of the commons, when resources are physically and legally accessible to more than one resource user. See Vendryes (2014) for a comprehensive discussion of the implications of the privatisation of land rights and Grafton (2000) for a comparison of three case studies used to examine the role of centralisation, privatisation and community.

25 In Schlager \& Ostrom's scheme (1992) owners have the most significant bundle of rights, including the rights to access and withdrawal, the right to manage, the right to exclude and the 
bundle of rights, including rights of access to the land and exclusion, but they do not have the right to alienate the land. The right of management and withdrawal can be shared between board members and farm managers.

Besides the allocation of property rights, Ostrom (1990) points out the importance of 'institutional details' about the development, operation and control of property rights. ${ }^{26}$ She also observes that some CPR users have designed their own rules and created sustainable and robust institutions, known as self-organised institutions, to undertake the management of their CPR. By institutions she means:

\section{the sets of working rules that are used to determine who is eligible to make decisions in some arena, what actions are allowed or constrained, what aggregation rules will be used, what procedures must be followed, what information must or must not be provided, and what payoffs will be assigned to individuals dependent on their actions (Ostrom, 1990, p. 51).}

Ostrom $(1990,1993,2000)$ also suggests that the success of self-organised institutions can be a result of locally evolved norms of reciprocity and trustworthiness, and the presence of leaders. Moreover, she considers it possible to identify a set of eight 'design principles', which can help explain the effectiveness and permanence of selforganised institutions in the long-term and over multiple generations. These principles are clearly defined boundaries, congruence between appropriation and provision rules, collective-choice arrangements, monitoring, graduated sanctions, conflict-resolution mechanisms, minimal recognition of rights to organise, and nested enterprises. ${ }^{27}$

Drawing on Ostrom's work, Wade (1987) notes that a successful organisation also depends on the characteristics of the resources and user groups. Chances of success increases when groups have few members and CPR are small. Kingi (2009) examines the underlying causes and consequences of having a small block of Māori freehold land with

\footnotetext{
right to alienate. Proprietors lack the right to alienate, claimants lack the right to exclude and alienate, and authorised users have only the right of access and withdrawal.

${ }^{26}$ For further discussion about institutions see Ostrom (1986).

27 Kahui and Richards (2014) use Ostrom's design principles and illustrate that prior to colonisation the southern tribe Ngāi Tahu had an integrated management system that aligned with the principles necessary for successful ecosystem based management - a prerequisite for sustainable resource management.
} 
many owners. He suggests that the possibility of increasing land area for farming activities - either by clustering blocks or farming collaboratively - depends on the ability of board members or landowners to establish a Māori land governance structure. In the context of Māori freehold land, in Chapter Two, I provide an example of how cooperation and trust among multiple owners can be crucial components for deciding whether to allocate land for forestry.

Finally, another seemingly important conceptual element is the Institutional Analysis and Development (IAD) framework (McGinnis, 2011; Ostrom, 2005; Ostrom, Gardner, \& Walker, 1994). The IAD framework concentrates on an 'action arena' or a social space where 'actors' (for example, board members, landowners or a farm manager) interact, solve problems or make decisions regarding an "action situation" (such as land-use decisions) (Ostrom, 2008). The action arenas are influenced by exogenous variables such as biophysical conditions (e.g. quality of the land), attributes of community (for example, landowners of a block of land who are part of the whakapapa or linage), and rules-in-use (e.g. the TTWM or mātauranga Māori) (Tucker \& Ostrom, 2005).

\section{Multiple case study approach: methodology}

This section introduces the multiple case study approach (Yin, 2012, 2015) used for this research and outlines the methods used to collect and analyse data. To collect relevant information about each case study, I conducted face-to-face semi-structured interviews to learn about how decisions are made, preferences and strategic goals of the group, and factors that facilitate or inhibit decisions. I selected the three case studies based on recommendations from two researchers, who were involved in a project with several Māori farms only administered by different Māori land governance structures. I did not have any contact with a Māori farm with no governance structure.

\subsection{Sample and data collection}

Engagement with the participants in these case studies began by contacting two researchers who were working with a network of Māori farms. ${ }^{28}$ During May 2017, hui

${ }^{28}$ This project aimed to identify potential management practices, which could be used as a mitigation option to reduce the greenhouse gases (GHG) emissions of the Māori farms involved in the project. For further information about this project see West et al. (2016). 
(meetings) were organised at the farms to present the results of the researchers' work. The researchers kindly invited me to these meetings, where I met kanohi ki te kanohi (face to face) and talked about my personal interest in learning about their decisionmaking processes. I also asked them whether they would be interested in participating in this $\mathrm{PhD}$ research. The decision to participate was made following consultation with other trustees or committee members not present at the hui. I followed up their decision by email and telephone. Once the board members had agreed to be part of the project, I was invited to carry out face-to-face interviews. Ethics approval was granted by the Victoria University of Wellington Human Ethics Committee 24856.

I conducted the interviews during August and September 2017. Each interview lasted up to an hour, was audio-recorded and transcribed verbatim. All participants were informed of their rights to confidentiality and anonymity, their rights to refuse to answer any specific questions, and their rights to withdraw from participation at any stage (see Document 1-1 in Appendix A). At the beginning of the interview, all participants signed a participant consent form (see in Document 1-2 in Appendix A) and received a copy of the interview questions (see Document 1-3 in Appendix A). They could choose not to answer any question or ask to turn the recorder off at any time. Participants also had the opportunity to review the transcript of their interview and change or remove any material from their interview transcript. None of these situations occurred.

I interviewed the chairpersons of boards of three Māori land governance structures involved in the farming sector, including one Māori incorporation (Tairāwhiti Station), one Ahu Whenua trust (Kerikeri Station) and one Ahu Whenua trust administered by Te Tumu Paeroa (Pongakawa Station) (see Table 1-1 on page 23). These farms are scattered around the North Island - one is a dairy farm and the remainder are sheep and beef farms. ${ }^{29}$

Given that some board members are not based where the farm is located, I was invited to conduct the interviews on the day the board met. In the cases of Tairāwhiti Station and Kerikeri Station I interviewed the chairperson of each governance structure

\footnotetext{
29 Initially, I contacted four Māori farms. For the fourth farm, I collected information from the farm manager, but it was not possible to organise a meeting with the trustees.
} 
and other board members who were willing to participate in an interview. I was also invited to the farms to talk with people involved in its operation. ${ }^{30}$

Table 1-1 Interviews sample

\begin{tabular}{l|lll}
\hline & \multicolumn{1}{|c}{ Tairāwhiti Station } & \multicolumn{1}{c}{$\begin{array}{c}\text { Kerikeri } \\
\text { Station }\end{array}$} & \multicolumn{1}{c}{ Pongakawa Station } \\
\hline $\begin{array}{l}\text { Māori land } \\
\text { governance } \\
\text { structure }\end{array}$ & $\begin{array}{l}\text { Māori incorporation part of a } \\
\text { limited liability partnership }\end{array}$ & $\begin{array}{l}\text { Ahu Whenua } \\
\text { trust }\end{array}$ & $\begin{array}{l}\text { Ahu Whenua trust } \\
\text { administered by the Te } \\
\text { Tumu Paeroa }\end{array}$ \\
\hline Interviewees & $\begin{array}{l}\text { One committee member } \\
\text { Chairperson } \\
\text { Director of the partnership } \\
\text { General manager }\end{array}$ & $\begin{array}{l}\text { Three trustees } \\
\text { Independent } \\
\text { consultant }\end{array}$ & $\begin{array}{l}\text { Responsible trustee } \\
\text { Rural advisor } \\
\text { Farm manager }\end{array}$ \\
\hline $\begin{array}{l}\text { Location of the } \\
\text { interview }\end{array}$ & BDO office and the farm & $\begin{array}{l}\text { Trust office and } \\
\text { the farm }\end{array}$ & $\begin{array}{l}\text { Te Tumu Paeroa office in } \\
\text { Wellington and the farm }\end{array}$ \\
\hline
\end{tabular}

\subsection{Question guide}

Aiming to enhance my understanding of how Māori land governance structures help landowners to make decisions on land utilisation, I generated a semi-structured question guide to examine information about the farm, land management and different components of decision-making processes. For the question guideline, see Document 1-3 in Appendix A. During interviews, I loosely followed the question guide but took the opportunity to follow up on the interviewees' answers and any new directions they initiated (Kvale \& Brinkmann, 2009).

\subsection{Data analysis}

The basic principles of qualitative inductive content analysis guided the process analysis of interview transcripts (Vaismoradi, Turunen, \& Bondas, 2013). Either an inductive or

\footnotetext{
30 These interviews were conducted as part of the project "Barriers to Adoption of 'no-cost' mitigation options". This project aimed to better understand why some apparent 'no-cost' options for agricultural mitigation (reduction of biological GHG emissions), are not adopted, or only adopted in part. No-cost mitigation options are investment, technologies or practices whose adoption reduce the farm's GHG emissions without reducing farm profit. This project was in coordination with Motu Economic and Public Policy Research Trust, Manaaki Whenua Landcare and AgResearch. For further details see Cortés Acosta et al. (2019).
} 
deductive approach may be used for qualitative content analysis: which of these is the most appropriate depends on the aim of the study (Elo \& Kyngäs, 2008). Given that my knowledge about Māori land governance structures was limited, I chose the inductive approach.

Since I started my studies, I have been mindful of the importance of developing a strong understanding of the Māori land context to ensure that my research with Māori is respectful, ethical, empathetic and useful (Smith, 2012). Therefore, the analysis of the interviews has been complemented by readings about Aotearoa New Zealand history, analysis of documents of the Waitangi Tribunal, lectures and several conversations with academics and members of the Māori community. My approach has been led by an interest in gaining an understanding of how Māori land governance structures can influence decision-making processes regarding Māori freehold land. Additionally, the questions were focused on actual land management, rather than possible considerations about land-use transitions.

The general steps for inductive content analysis are preparation, organising, and reporting the analysing process and results (Elo \& Kyngäs, 2008). First, I read all interview transcripts to become familiar with the data collected. Second, I used open coding, created categories and then grouped the list of categories under higher-order headings. Third, I documented the results and findings of each case study. To preserve confidentiality, I omitted or briefly modified any personal details or specific details of the land and the Māori land governance structure. These changes did not alter the main story. Data analysis was computer-assisted using NVivo 12.

\subsection{Study limitations}

This research utilises qualitative research methods with a small number of participants in order to provide an initial exploration of how Māori land governance structures can help to make decisions. The information documented in my research only considers the points of view of some board members and does not include landowners' perspectives. The results are specific to each case study and might not be suitable for generalisation, affecting the external validity of the results.

Future research will need to build on the findings from this study by exploring a much broader number of Māori farms (both with and without a Māori land governance structure) as well as talking to more actors involved in decision-making processes, such 
as other board members, landowners, farm advisors or people from different farming networks.

\section{Results of the case studies}

In this section, I present three case studies of Māori farms administered by different Māori land governance structures to exemplify how Māori land governance structures influence decision-making processes. First, Tairāwhiti Station is a sheep and beef farm administered by a partnership among three Māori incorporations. Second, Kerikeri Station is a sheep and beef farm administered by an Ahu Whenua trust, but reflects the influence of the Department of Māori Affairs on former decisions on land use and management. Third, Pongakawa Station is a dairy farm administered by an Ahu Whenua trust administered by Te Tumu Paeroa.

\subsection{Tairāwhiti Station}

The leading enterprise at Tairāwhiti Station is a sheep and beef farm administered by a limited liability partnership, constituted by three Māori incorporations. The farm's operation comprises several blocks of Māori freehold land and general land, with an effective area of nearly 7,000 hectares. The partnership allows three incorporations to join commercially, but each one retains their land and shareholders register. More than 2,000 shareholders share the annual distribution according to their input proportions.

There's some [shareholders] in the three of them [Māori incorporations in the partnership], some are in two and some are just in one. It was that kinship that made them bring their land together and it will be owned by them and their descendants for usage forever. That's the way that you maintain your land. You don't own that gate, or that wheel of the tractor. You just own so many shares, and it's a given number of shares in that incorporation. That share has a value and it also has a return, what we call a dividend. So number of shares you got, that's what you get as your return.

It was explained to me that Tairāwhiti Station is an operational body where the farm operates as a unit of business. However, other activities also operate on the station. There is, for example, a marae (meeting grounds), a school and areas of native bush with 
significance for shareholders and their whānau. I concentrate my analysis on decisions at the farm level; therefore, when I refer to Tairāwhiti Station, I am specifically referring to the farm.

\subsubsection{How decisions are made}

As mentioned, the partnership is among three Māori incorporations. Each incorporation has its own committee of management. Shareholders of each Māori incorporation democratically select the members of the committee of management, who are part of the whakapapa (lineage) of the land. Each committee of management votes for and selects a director who represents them at the partnership board.

The partnership board has five directors in total, the representatives of the three Māori incorporations and two independent directors. The independent directors are not part of the whakapapa of the land, but are members of this board as they offer expertise about the sheep and beef business.

The partnership board appoints a general manager responsible for making the operation as efficient and profitable as possible. The general manager has entire control of the farm's operation, including employment of staff members and managing 16 fulltime employees. Additionally, the partnership supports their decisions through a group of accountants, auditors, bankers and lawyers.

There's no way we would ever make any decision without having these guys involved [general manager and independent board members]. The general manager, he attends every meeting. He has to come back with all the costings, the finances. If you're going to borrow money, how much it's going to cost us. What is the return we're going to get, three, five years, and when it's going to start showing.

The structure of the decision-making process from Tairāwhiti Station is complex. Although decisions are made at a combination of the governance and the operational levels (see Figure 1-1, below), different actors and roles are involved depending on the type of decision. At the governance level, the three committees of management and the partnership board are the main actors. At the operational level, the partnership board and the general manager are the main actors. ${ }^{31}$

\footnotetext{
${ }^{31}$ I designed the interviews using an exploratory approach. It was during interviews that I realised the complexity of the structure of the decision-making process at Tāirawhiti Station. Having an in-
} 
Figure 1-1 Structure of decision-making processes - Tairāwhiti station

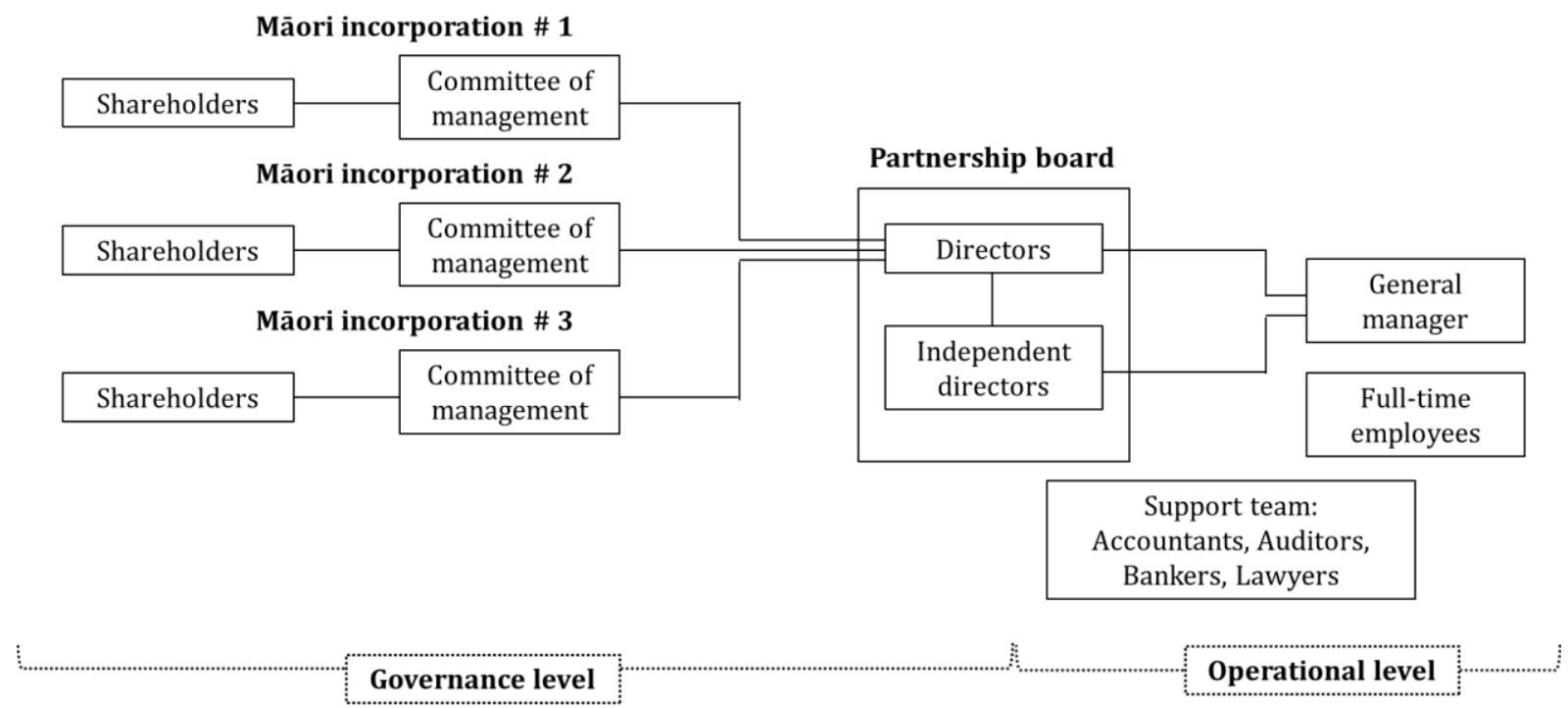

\section{Communication channels}

As the decision-making process involves different agents and decisions, communication has several channels and targets. The communication channels used include meetings, information on the website, emails, courses and reports on the farm's operation and financial statements.

There are several opportunities for decision making, including the two main forms of meetings. One is partnership board meetings where discussions concentrate on the farm's operation. They meet on a regular basis, every six weeks. The minutes of the meetings are shared with each of the committee of management. The second is committee of management meetings. These meetings are fortnightly and independent for each Māori incorporation from the partnership. Before each meeting, a report and a plan for the meeting is sent to each committee member. In these meetings committee members discuss financial statements, aspects associated with their land, such as possible diversification options or decisions about topics that have not yet been decided. The director brings these to the meeting of the partnership board.

We sent the notice out. Everybody had to come back with what they thought could be changed or not changed. And that's how we work, so that it's a collective decision for us to say: this is what the board have

depth analysis for each of the incorporations would require further analysis that was beyond the scope of this project. 
done and with that comes a bit of change but not much change, because they have faith in the people that they've put on the board. I think, if something doesn't go right, we, the board, we are the ones that have to answer to the shareholders.

When I conducted the interviews, I was kindly invited to participate in one of the committee of management's meetings and listened to their discussions. Although the general manager has entire control of the farm's operation, in this meeting, committee members can ask questions or express their concerns about the operation of the farm and the general manager's report. This report was based on a land environmental plan for Tairāwhiti Station. In this report, procedures were explained relating to fertiliser plans, pasture management and erosion control plans, among other things.

We [the committee of management of one of the incorporations] have a properly structured meeting. Tomorrow, we'll be discussing the business that we actually do on the farm, and also what the partnership is doing for us, and a lot of it's to do with that land environment plan.

We've got this land environment plan. We want to make sure that this piece of native bush is protected; it's got historical significance. This piece of water here has got special significance, so we need to fence it off, so animals can't get in there, protect it. And then it's the river, how do we make sure that that's protected from the activities of farming?

\subsubsection{Preferences and strategic goals that influence decisions}

Both the partnership board and the three committees of management are guided by social and cultural responsibilities to meet on behalf of shareholders. Intergenerational resource sustainability and protection of their land influence preferences and strategic goals. For instance, they support the marae in the rohe (area), local schools and social activities.

Cultural values are what guides us. Our tūpuna [ancestors] came to this country in the early 900s. They arrived here on this soil and so from there, it is evolved into what we are today. We were the ones that stayed and worked the land, so whatever we have in our hearts that came through from our old people stays with us that we're protecting 
this land for generations to come, and we're working it the best way we can.

One of the most important things about Tairāwhiti Station is that we're going to be here forever. So for ongoing generations, it's being Māori land, it can't be sold, so we're always looking at different ways to be more sustainable. So sustainability's always been an ongoing focus. We are very mindful of what we're doing, and do look at ways that we can reduce our environmental impact.

Through the partnership, they collectively work towards making Tairāwhiti Station a business that provides sustainable dividends for shareholders, and supports social and cultural responsibilities with the land and the people.

Everybody comes under the umbrella of the values that the organisation [follows]. You might be a Pākehā person, you might be a Colombian, but these are the values that umbrella everything. So we're saying these are our values and we're going to impose them above everyone. So these independent directors, they need to observe the values that are important to us.

\subsubsection{Factors that facilitate or inhibit decisions}

A five-year business plan guides the operation and management of Tairāwhiti Station. The plan follows the principles of a sustainable farming system and resource management. This plan includes ethics, economics, and environmental objectives, which guide the decisions and interaction of both the general manager and the partnership board.

Independence in the operation of the farm has been critical for the success of the sheep and beef enterprise. The general manager has autonomy for making decisions that help to optimise the performance of the farm, including the evaluation and adoption of farm management practices, even if these involve certain levels of risk. For example, he ran a pilot study to test electronic tags on all breeding sheep and cattle and, based on the results of the pilot, decided to implement this technology. Given that it involved a considerable investment, he consulted with the partnership board and informed them of the results of the pilot. 
Tairāwhiti Station is committed to research and development on our farms and we're involved in a number of different projects and programmes covering a wide range of farming aspects.

At Tairāwhiti station, employment follows industry standards and high expertise is required. As mentioned previously, the general manager has the independence to make decisions regarding the farm's operation, including employment requirements for the farm's operation.

When the jobs come up or are advertised, we give them the - anybody the opportunity to have an interview and they have to meet what the standard is on our farm. They can't just come along and say I'm [a director's] grandson and I want a job on here. They can't do that, they have to be able to pass the tests, they have to be what we're actually looking for, and then they have to show that we have chosen the right people for the job.

Communication between committee members and the partnership board is based on cooperation and trust. There is a space to express ideas, concerns and also ask questions. Discussions are motivated by trust, support and reciprocity.

We do have the right to question anything. So there's that open communication, so we can say: - well, I don't like how this is happening, or we've got something else that's a priority - I would describe it as a fairly easy communication across these groups, because we know each other, through families, and through everything else, because a lot of these people, they invariably all live here or come from here. It's not like we're talking to another company or something, so there's a lot of history here.

Although the main business operation concentrates on the sheep and beef enterprise, there is a possibility for future diversification of their portfolio. Horticulture has been discussed as a potential new enterprise. This discussion was motivated by some committee members questioning whether another activity could employ more people or could be beneficial for certain land blocks.

[Question: where does the information about new enterprises come from?] That inevitably comes from here [committee members]. We're 
not paying them [the partnership board] to come up with other things.

We're paying them to run the business that we've got.

In terms of diversification, there's been some hesitation by a lot of people and shareholders, and these committees. They're like - well, wait on, this is our business, and we don't really want to change what it's doing well - But there are a number of us agitators, younger agitators who are saying: well, is this the best use of our land? Is growing sheep the best use of this particular land?

The possibility of allocating land to horticulture activities as a new enterprise is in the evaluation phase: possible allocation may need to overcome several challenges before a decision is reached. Horticulture would be considered a new unit of business. The possibility to diversify or start a new enterprise involves decisions on land allocation, development of expertise and a new business model. It might also require new staff members, information and investment.

Part of the discussion has been that if we established a horticulture operation, it would be a separate limited liability company. It won't come under this person [general manager]. It may involve these people [the partnership board and the three committee of management]. But it would be separate from his operation. You'll have someone else who, or another company who we might form a joint venture with. They will be responsible, and they'd be allocated these 10 hectares or 20 hectares which they have access to, but not the rest of the farm.

As I will present in Chapter Two, evaluating the option of going into a new land activity requires extensive information and consultations at different levels of the decision makers, the board members and landowners (or shareholders). In the case of Tairāwhiti Station, I identify similarities, where any decision on moving to a new landuse might take some generations and may need to overcome resistance to change from shareholders. Committee members might need to reformulate their vision as a business, but they also need to be certain that they have enough information to support their decision.

At the moment we're talking about different things, as far as horticultural things or fruits and that's something that we ... well I don't 
know a lot about. So I would find the best person that would give us advice on how and what we should do, and how to go about setting that up. But if to me, and to us the board [the partnership board], those figures don't stack up, we have to get outsiders to do that, and give us the information that we want, and then we as a board will make the decision to say yes or no.

Finally, risk and capital restrictions can inhibit decisions. The risk can be associated with health and safety, biosecurity and commercial risk. When diversification into horticulture was discussed, investment and capital restrictions were mentioned. I was told that one of the incorporations might not have the ability to access adequate capital, but collectively (across incorporations) they were exploring possible solutions.

They're [the committee of management of one of the incorporations] going to have to look to either borrow from the bank or somehow to finance it. So it's a bit of an uneven ... As much as we all have equal rights, these two groups have more means than this one. So again, it's about, and what we've maintained is if we're in it together, we're all in it together. So you can't go, "Oh well, little brother, you're out." You know? So there needs to be an inclusiveness that if we're all in, we're all in.

\subsection{Kerikeri Station}

Kerikeri Station has a long history influenced by amalgamation of several land blocks, the intervention of the Department of Māori Affairs, landowners' immigration to cities, and a strong connection between landowners and the land. Nowadays, two main enterprises take place at Kerikeri Station - a sheep and beef farm and a commercial planted forest. I concentrate on the operation and decision-making processes of the sheep and beef farm.

The main enterprises are kai [food], dry stock, beef and sheep and forestry. The forestry is managed by another person, independently of the farm manager and a forestry advisor. Other activities are communication leases with Vodafone and Telecom.

The amalgamation of several blocks of Māori freehold land as one unit was based on a customary relationship with the land, which has been the basis for the legal title and 
maintained over generations. Then, in the mid-20th century the Department of Māori Affairs developed and administered this unit of land as part of a land-development scheme. In 1990, the trust was established as a 483 trust and after the TTWM, it became an Ahu Whenua trust.

In the early 20th century, they had a papatupu [ancestral land] where they assembled with the tribal leaders. Later, they split up the land into what they considered economic, working, theoretically farming blocks. That process wasn't working too well, and so they had a recharge, a rethinking. This is what we have at the present moment - one big block, all amalgamations of shares.

Although landowners were in other parts of Aotearoa New Zealand, as a result of immigration to cities to secure employment, they maintained strong links and identity with the land. This connection remains today.

There were iconic symbols around here which everyone identifies with. You have your maunga [mountain], you have your awa [river], and you have your marae, and probably you should have a church and your sacred grounds which are wāhi tapu [sacred places], burial grounds. So that was the attachment to the land.

\subsubsection{How decisions are made}

The governance of the land and the operation of the farm are separated. An Ahu Whenua trust is in charge of the governance of the land on behalf of nearly 1,500 landowners. The farm's operation is led by a farm manager, who operates the farm in an effective area of 1,000 hectares (see Figure 1-2, below).

Figure 1-2 Structure of decision-making processes - Kerikeri station

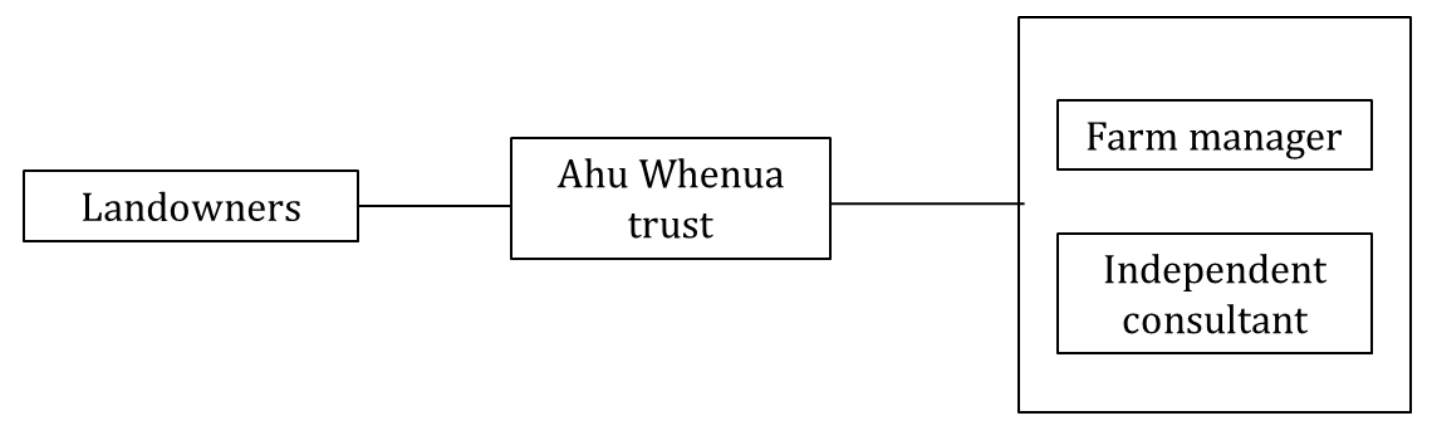




\section{Governance level}

As mentioned before, an Ahu Whenua trust directed by seven trustees is in charge of the governance of the land. Trustees have been democratically elected by landowners and are part of the whakapapa (lineage) of the land, meaning that they are landowners and descendants from the former owners. The trust was initially established to centralise decisions on the use of their ancestors' land in a viable business to meet the social and economic needs of the community. According to the Trust Order:

The objects of the trust shall be to provide for the use and management of the land to the best advantage of the beneficial owners, the better habitational or use by beneficial owners, to ensure the retention of the land for the present Māori beneficial owners and their successors, to make provision for any special needs of the owners as a family group or groups, and to represent the beneficial owners on all matters relating to the land and to the use and enjoyment of the facilities associated therewith.

I was informed that the trustees might not need to be experts in the sheep and beef industry, but it is critical that they are interested in trustees' duties and also willing to engage with and communicate with other landowners. The trustees work closely with the operational team to make decisions. Thus, the trustees evaluate business plans (e.g. budgets or investments) that the operational team proposes.

\section{Operational level}

The farm's operation is independent of the governance level. This separation is considered a reason for the success of the enterprise, as experts in the field lead the operation and management of the farm. The operational team involves a farm manager, an independent consultant, an auditor, and an accountant.

You might present a summary of reasons to the trustees ... the structure of probably a number of Māori farming organisations. We often get on the governing body people who don't know much about farming, and I've found my role [independent consultant] has actually drifted into 
providing information via that to layman's language. It means language that anybody can understand.

\section{Communication channels}

The formal channels to make decisions involve bi-monthly trust meetings and the Annual General Meeting (AGM). In trust meetings, the board is informed about farm performance, and discusses budgets, grants and the approval of accounts.

Probably the best thing I've done with the trust was we did a five-year plan. And we went right through everything, and one Saturday we went through the plan right from the beginning. It started with resources, the land types, soil types, farm policy, finishing cattle, breeding sheep, pasture production, fertiliser history.

At the AGM landowners receive the trustee's report, the farm manager's report and, generally, the business performance report. The financial statements of the trust are considered and approved, and when necessary, new trustees are elected. Additionally, the trust is in continuous communication with landowners by email and relevant information is updated on the farm website.

\subsubsection{Preferences and strategic goals that influence decisions}

Kerikeri Station is administered and managed under the guidelines defined in the trust's five-year plan. This plan highlights the introduction of sustainable operations including water reticulation systems, protection of the waterways from farm activities, and pasture improvements, for instance. Furthermore, the preferences and strategic goals of the trust are guided by the long history and ancestral connection with the land, so that the landowners' well-being is a priority. Productivity and environmental sustainability goals drive decisions on land use.

[Question: What are the current goals and vision overall for the farm?] Environmental sustainability [is] probably one of the main ones ... and productivity. I think those two go together. If we can produce and sustain ourselves, provide employment for the up and coming (the 
beneficiaries). In this case, provide some sort of climate that we can use the farm as the basis for utilising these resources.

I was told that trustees are guided by cultural and social values, such as their role as kaitiaki of the land, but they also maintain a strong connection within the hapu. Simultaneously, the farm manager may consider these values, then all decisions are aligned with the interests of the whole group.

[Question: What cultural values are involved in the governance of the farm?] Cultural would be Ngāti Kawatanga. How would you translate Ngāti Kawatanga? Being yourselves and being collective. Like we're all connected in there through one being. And we're all connected to all Māori in this country through the same being. And we're connected to the world in the same [way].

Farm management [in Māori farms] has to be aware of the cultural issues, so that it doesn't stomp all over them. The social issues are more to do with you've got the farm, so it goes profit, and it goes to the trust. The trust uses that money as it sees fit. It will go to social benefits. In Kerikeri Station's case - study grants for kids going to university, and there's some small payments to the older people, pensioners.

The farm activity is translated in profits, which the trust invests back into the community through tertiary grants or the maintenance of the marae, for instance.

We've always had a distribution policy, so our distribution is in the way of the grants and a lot of the focus of that is on tertiary grants. So we've had over $\$ 300,000$ paid out over the existence of the trust to tertiary students.

\subsubsection{Factors that facilitate or inhibit effective decisions}

The Trust Order is an important guideline for the trustees and facilitates effective decisions. This document explicitly defines the powers of the trustees, their restrictions and their obligations. Additionally, it is expected that trustees are engaged in the trust's duties and communicate comprehensively with other landowners. Simultaneously, it is expected that landowners support decisions made by board members. 
The trust Order also defines that trustees can employ a group of people to help to carry out the powers of trustees. At Kerikeri Station, employment follows the industry standard. Additionally, the Trust Order states that trustees may hire experts, but requires that their remuneration not exceed the market rate.

Good relationships and communication between trustees and the operational team lead to effective planning and improved performance. In interviews, it was mentioned that separating the decisions on governance and the management of the farm has been critical for the performance of the enterprises that take place on the land.

Given that working on the farm can involve several risks for health and safety, workers are required to be trained or have the expertise in knowing how to work with livestock or machines. I was told that in cases where someone wishes to work on the farm but does not have the necessary expertise, the local polytechnic has suitable courses and the trust has tertiary grants to support studies.

As mentioned previously, the trust has tertiary grants which have been used to develop capability within the whānau. Nowadays, the trust can support their decisions based on the knowledge and expertise of different well educated whānau members.

When we last looked at the diversification, we actually had to do it ourselves because we didn't have anyone else to do it. But now we've got these contacts that are academics, and also in the business world from the shareholders. And so we're turning to those people now. And that's a result of the tertiary grants.

Another factor mentioned was the importance of having access to capital. Access to capital is an important barrier for Māori landowners, which can be associated with restrictions established by the TTWM on the alienation of Māori freehold land, so using this land as collateral can be difficult. ${ }^{32}$ At Kerikeri Station, trustees have learned to cope with this barrier and they recognise the importance of having a positive financial history, where the trust can borrow money, without using land as collateral.

32 The TTWM permits the permanent alienation of Māori freehold land only with the consent of $75 \%$ of the owners or beneficiaries. These rules are based on a principle of retention, meaning that the remaining land in hands of Māori communities cannot be alienated (Boast, 2008; Harvey, 2018). 
Previously, the banks wouldn't lend to incorporations or Māori trusts ...So we had difficulty arranging finance. But the rules have changed now, and we have learnt to grow with it, so we've built up our assets, so we don't use the land as collateral anymore. We use other assets.

Finally, the Mãori Land Court can be a barrier to implementing a decision made by the landowners. I was told that in the AGM, for example, landowners voted for some trustees, then the trust reported the decision to the Māori Land Court; the Court has been slow in its response, so this administrative process has taken longer than expected and the trust has not been notified about the approval of that decision.

\subsection{Pongakawa Station}

The main enterprise at Pongakawa Station is a dairy farm administered by an Ahu whenua trust on behalf of 42 landowners. This Ahu whenua trust is directed by Te Tumu Paeroa and four advisor trustees. The farm comprises a block of Māori freehold land and two blocks of general land, having an effective area of nearly 150 hectares.

The common picture on Māori land ... is passively leased to other people. It's done that way for numerous reasons, but the big ones are lack of scale, lack of capability, lack of capital to invest, or a combination of those. The biggest change that's happened here [at Pongakawa station] is the creation of an enterprise, on their land, that's enabled them to actually take full and total control of that land, and the business on top of it.

\subsubsection{How decisions are made}

At Pongakawa Station decisions are made by a combination of the governance and the operational levels, as shown in Figure 1-3 (below). At the governance level, decisions are made that involve the process of administering the use and development of land resources. The board also makes decisions on choices of land use or major changes that may require investment. In this case study, the decision to use the land for dairy has already been made. Therefore, the main decisions are about optimisating farm administration. At the operational level, decisions are made that involve the operation or organisation of the specific enterprise (the dairy farm) to maximise production and profits. 
Figure 1-3 Structure of decision-making processes - Pongakawa Station
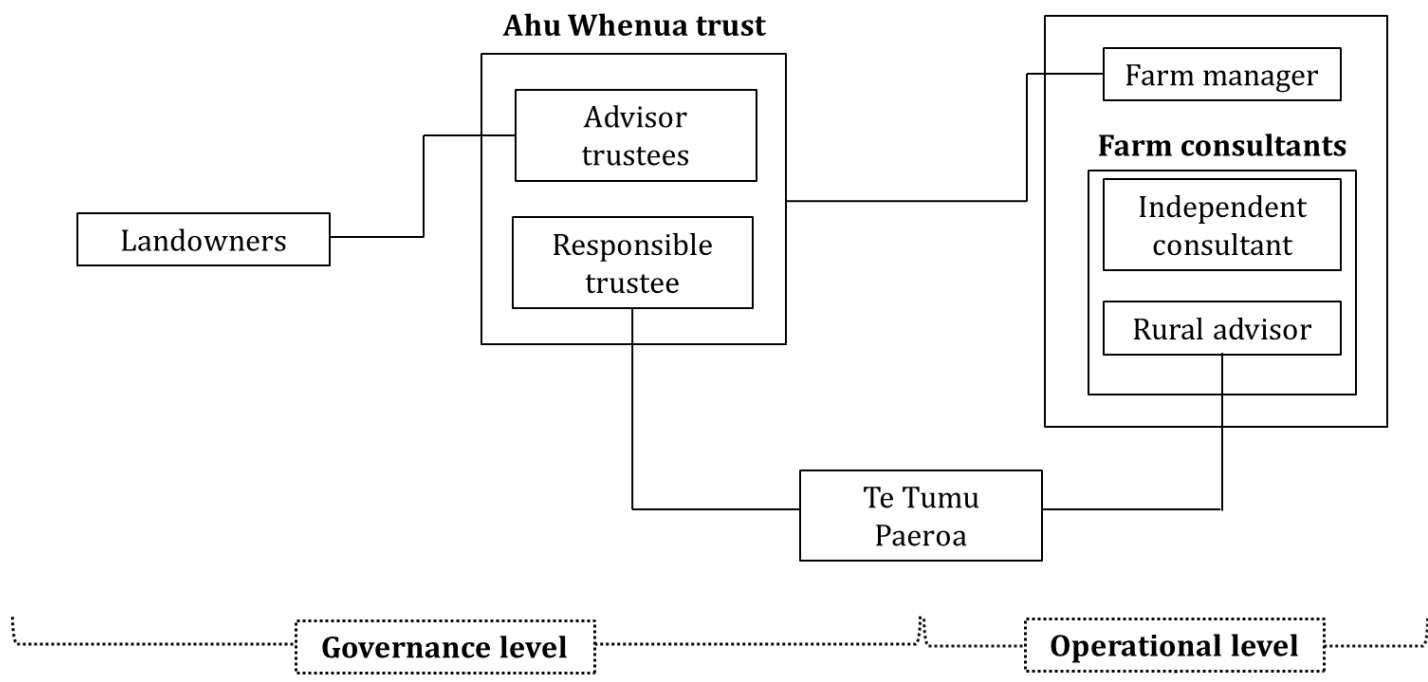

\section{Governance level}

The governance level involves Te Tumu Paeroa as a professional responsible trustee ${ }^{33}$ and four advisory trustees, who are democratically selected by landowners. As established by the TTWM, the responsible trustee oversees administration and management of the business, preservation of the trust assets, and collection and distribution of the trust's income. The advisory trustees are the link between the responsible trustee and landowners. The trust's assets are the two land blocks of general land, the cattle and the infrastructure of the farm.

The initial strategic plan for the trust was to establish an enterprise that could be used as a vehicle to achieve landowners' aspirations. After almost 10 years of operations, the trust has successfully achieved this plan through a dairy farm. The farm has expanded to two land blocks of general land owned by the trust. These land blocks have been used as collateral for a credit loan to fund the farm activities.

Initially the strategic plan was: let's establish a good farming business, so that it can take us into the future and we can use that as vehicle to

\footnotetext{
33 The TTWM defines that a responsible trustee can be a private or a professional agent. When private, this role can be filled by one of the owners or someone known by the owners, while a professional responsible trustee can be Te Tumu Paeroa, the Māori trust board, a body corporate, a Māori incorporation or a trustee company within the meaning of the Trustee Companies Act
} 1967. 
realise our aspirations. Well, that vehicle's now up and running, so part of the goal is obviously to keep focused on that very important vehicle.

The dairy farm is a commercial operation jointly run by Te Tumu Paeroa and the landowners, who are represented by advisor trustees. Te Tumu Paeroa has brought expertise in the farming business and landowners have contributed their land to be used for a commercial purpose. The advisory trustees assist Te Tumu Paeroa in the decisionmaking process and are highly engaged in decisions on cash flow, disposal of assets and plans for the enterprise, for example about whether to grow the dairy farm or diversify the portfolio.

We [Te Tumu Paeroa] run the farm as if it were a company ... We put ourselves in the role of governance decision support. ...We're not the trust team; we're the land development/business performance team. We're able to sit outside of that and apply ourselves and just provide services directly to the trustees in their role as kind of like directors for the farm. We're in there obviously being the head director ... we work together as if we were a board of directors around a business plan and a budget to make decisions about the future.

Te Tumu Paeroa has played a critical role to help the trustees of Pongakawa Station to acquire expertise and develop skills to administer the farm by themselves in the future. The group of advisor trustees are not dairy farmers, nor involved in farming activities, but they are willing to learn and be involved in the business. They also have passion for their whenua, their legacy and a sense of responsibility for the land and the people.

They [the advisor trustees] want to do something. They're engaged. They want to learn. They don't need to be professional dairy farmers, and they don't need to be bankers and all that sort of stuff. We've shown that we've got really great trustees who can come from other, totally different unrelated industries, but they just have to care about it, and they have to have some passion.

\section{Operational level}

The operational level involves a farm manager and two farm advisors, one from Te Tumu Paeroa and an independent farm consultant. The operation of the farm is under a performance model, which incentivises production through increases in profits. The 
distribution of the profits is $75 \%$ for the trust and $25 \%$ for the farm manager. The farm manager is responsible for matters regarding staff members and is responsible for health and safety compliance requirements. From a governance perspective, it is an effective way to protect the board from risks at the operational level. None of the agents at the farm's operational level have voting rights, but they advise the trust on decisions regarding farm management and operation.

\section{Communication channels}

Two main hui are part of formal decision-making channels to make decisions: the quarterly trust meetings and the AGM. In trust meetings, the board discusses issues about the operation of the farm based on advice received from the Farm team. An example of decisions the board would make, as opposed to the farm manager, would be to buy a new farm to expand their activities. In the AGM landowners are informed about the farm's performance in the last year. In this meeting, landowners and trustees discuss plans for the enterprise, the distribution of revenue and possible investments, approve budgets, and elect trustees every three years. Additionally, the trust is in continuous email communication with landowners.

$$
\begin{aligned}
& \text { When those advisory trustees and ourselves [Te Tumu Paeroa] are } \\
& \text { sitting together talking about the farm, and planning, and approving } \\
& \text { budget, think of that as the board of the farm, the board of directors, } \\
& \text { effectively. When we have the AGM with the owners, think of that as the } \\
& \text { company shareholder meeting, the Annual General Meeting, where the } \\
& \text { directors have to come and explain their performance for the year. And } \\
& \text { that's when you'll get people stand up ... all that engagement helps to } \\
& \text { form thinking for the next year, and future years, for planning purposes. }
\end{aligned}
$$

The trust seeks to make well-informed decisions and analyse possible advantages and disadvantages, for example, being up to date and learning about the latest farm management practices and other factors that could affect the performance of the business. This information comes through networks of farmers, courses and farm consultants.

The information about possible farm practices ... the introduction of the ETS [Emission Trading Scheme], or regulatory change or whatever. That's going to find its way into farm business either via ourselves, our 
farm supervisor, our farmer, and all their various networks, and our various networks, and it's either going to be triggered proactively because we decide to make a decision now, based on what we believe might occur, or it's going to happen to some extent reactively if something is put upon us.

This information gathering could be time consuming, but it is critical as the board has an immense responsibility to the land and landowners.

\subsubsection{Preferences and strategic goals that influence decisions}

Decisions on farm management and land administration consider a quadruple bottomline approach: social, economic, environmental and cultural goals. Social and economic objectives are relatively straightforward to comprehend and fulfil, as they are associated with a desire to look after people and maximise profits. However, environmental and cultural goals seem to be intertwined. Although they are framed as distinct goals (and thought of that way by decision-makers), there appears to be a considerable overlapping in the substantial outcomes pursued. Environmental goals, for example, include meeting compliance requirements as required by law and regulation, but can also include how decision makers perceive their roles as kaitiaki of the land.

From our perspective, environmental is purely and simply, environmental compliance requirements as required by law, and regulation. Whether that be central government or regional government that could be for things like water usage, water take ... but then also there's a whole bunch of industry spec that we have to meet with regards to fencing, with waterways, riparian planting.

When we get to cultural goals and objectives from our perspective that is what we refer to as kaitiakitanga, which is stewardship or guardianship of te whenua, of the land. In our role as kaitiaki or guardian, this is more about culturally how we are going to utilise that land. For a period of time, we didn't have to do [required by law] riparian planting, for example. Just the fence was good enough, but we used to do that anyway, we used to cost that up as our cultural 
investment, around how we wanted to look after our land. We had cultural investment.

\subsubsection{Factors that facilitate or inhibit decisions}

Several factors may facilitate or inhibit decisions about land management or any kind of considerations in regard to diversifying the portfolio at Pongakawa Station. A long-term vision, a risk assessment, and acquiring expertise are among the factors interviewees mentioned.

A long-term business plan is a crucial aspect for running the business and being able to define goals and then realise them.
A longer-term business plan. That is a major factor. So when we [Te
Tumu Paeroa] first came into this business, the annual budget was the business plan. One of the biggest changes that we made was: let's actually have a business plan that's got a little bit of time horizon on it, five years. Five years seems like kind of a period of time that's not too far away, but still far away enough to achieve something.

Access to trustworthy sources of information and having good leadership are key elements for supporting the decision-making process. The board is cautious when making decisions as they know that any decision will not only affect the current landowners, but also future generations. Intergenerational considerations are key when decisions and investments are made. Given the potential intergenerational impact of current decisions, the board members are continuously attempting to be well-informed about possible factors that might affect the performance of their business or affect the land.

Financial planning is an important consideration, as maintaining dividends for landowners is fundamental, but at the same time they have a saving and repayment plan in case an unlikely event occurs. The risk assessment involves features directly associated with the nature of the business and potential situations that could affect the land and future generations.

These are the risks that we typically have to manage on a farm. Stuff that we can't really influence, called market volatility and climate volatility. We can't influence what the market does, but we can keep our costs low to make sure when markets go down, we're protected from 
those sorts of swings. Because we're a trust, we should be a little bit more conservative and long term in our focus, and then put the Māori view on that, intergenerational. We'll never sell the land, we can tend to try and de-risk our systems.

Employment is an interesting consideration at Pongakawa Station. As mentioned previously, the farm manager makes decisions regarding staff members, and employment on the farm follows industry standards. Although the board would like to have more people from the community involved, they recognise that commitment, interest in farm activities, and expertise are crucial for achieving optimal farm performance.

Finally, I was told that the board is exploring the possibility of allocating resources for starting a kiwifruit business. When I conducted interviews, they were evaluating options and collecting information to support future investments, as going into kiwifruit growing would require new skills and a new business model. It may also possibly necessitate the hiring of a new farm manager for the orchard.

When you do business you do it right, so you start it up with the best of the best of resources and people available. So if they are not owners, that's just unfortunately too bad at that point in time. I know that sounds bad, but it's just good trusteeship. You've got to get the business right first. But then in the fullness of time, the longer-term aspiration would always be for that farm business to be under full control of the trust. And you know, like obviously the perfect scenario would be at all levels of that business, a whānau member's employed.

\section{Conclusions and lessons}

In this chapter, I aim to contextualise my research in the complex historical context that surrounds Māori land law, defined under the TTWM, and the reasons why the Māori land governance structures become an important body to overcome challenges due to the title individualisation. Based on fieldwork experience with three Māori land governance structures involved in agribusiness, I explore how Māori land governance structures can influence decisions on land utilisation and management. I use the lessons from this chapter to motivate the quantitative analysis developed in Chapter Three and Chapter Four. Māori freehold land is a land status defined after the Crown altered the 
customary regime to promote settlement and commercial use of the land in Aotearoa New Zealand. This particular land status is characterised by a complex ownership structure, which has created the need for Māori land governance structures to facilitate decisions among multiple owners. The TTWM defines specific parameters for the organisational arrangement of the Māori land governance structures, but the way each structure operates varies according to landowner preferences and the capability of board members.

Māori land governance structures help to facilitate decisions in a small group of people who have been elected democratically by landowners. Therefore, it is expected that decisions are aligned with landowners' interests and that landowners support decisions made by the board. The three case studies are examples of how the governance structures have been able to administer an agribusiness, balancing landowners' interests with optimal operation and performance by the farms. This might suggest that the three Māori land governance structures studied have been able to envisage a long-term investment, and overcome barriers such as capability or access to capital. This can be achieved by hiring those who can bring expertise to the business, even if they are not members of the whānau; and also by using other assets as a collateral, apart from the block of Māori freehold land.

I have learned from the case studies that decisions can be separated into the governance level and operational level. The governance level concentrates on decisions on long-term investment, potential changes in land utilisation or any potential situation that could compromise current and future generations. The operational level concentrates on decisions on farm management, by following the guidelines defined in the five-year plan. The operational team reports directly to board members. When the board needs to reach a decision the operational team have a voice, but cannot vote.

Overall, I conclude that having a Māori land governance structure in place might help to make 'successful' decisions about land utilisation and management, but this success not only depends on the legal constitution of the governance structure, but also on processes that are highly variable and on the presence of 'locally evolved norms' (Ostrom, 1990). These norms can be translated into cultural and social values.

I have learned from the three case studies that, in practice, each structure has a particular legal history, distribution of gains and losses, and rules to administer the land. Additionally, each structure operates under the umbrella of its Trust Order or constitution, which determines a specific allocation of the 'bundle of rights'. This 
suggests that each Māori governance structure can be seen as a 'self-organised institution' with different 'institutional details' about the definition of property rights.

In Chapter Two I discuss a situation where differing opinions between board members created difficulties in reaching decisions about land-use change. In Chapter Four I simulate a scenario where all Māori freehold land is treated as if it has a governance structure in place and then calculate the probability of land-cover transition.

\subsection{Directions for future research}

This chapter reflects an effort to explore issues regarding how governance structures can help landowners to make decisions on land utilisation on Māori freehold land. Future research could build on these findings by consulting a more comprehensive range of Māori land governance structures to determine the prevalence of the results. Some ideas for future research are outlined below.

(1) Explore the reasons why Māori land governance structures were put in place. It might require exploring files from the Māori Land Court. This analysis could help us understand whether a Māori land governance structure leads to certain types of land use or vice-versa. This issue might help resolve the endogeneity issues encountered in the analysis of Chapter Three.

(2) I was limited on resources and connections to identify a group of landowners who have developed a specific enterprise on a block of Māori freehold land where is no Māori land governance structure in place. It would give an interesting comparison of the decision-making process to examine an example of this kind. This type of situation may occur when the number of landowners is small and making decisions does not require a board.

(3) In this chapter, I presented the opinion of some board members. I suggest expanding the questions to landowners to explore their points of view on the role of the Māori land governance structure.

(4) A study on how Māori land governance structures operate in practice can provide further context for the decision-making process. It would be interesting to analyse the democratic rules for the different governance structures, how democratic decisions are made or how the youngest get involved in the voting process (to better understand how intergenerational interests influence decision making), for instance.

(5) In a Māori incorporation, landowners become shareholders of the land, whereas in Ahu Whenua trusts, landowners retain a direct ownership interest in the land. I did 
not establish what factors influence the decision to choose either a Maori Incorporation or an Ahu Whenua trust. This type of choice may occur when landowners' preferences are influenced either by a shareholder scenario or a landowner with ownership interest situation. This could be the subject of further research.

(6) As mentioned earlier, the success of Māori land governance structures relies on the capability and experience of board members in relation to governance and management. It would be interesting to explore and develop a benchmark profile of the skills and abilities of board members that influence decision making. 



\section{Chapter Two. Carbon farming on Māori freehold land: insights on decision-making processes}

In this chapter I explore the nature of the decision-making process associated with choosing to go into carbon farming, the strengths and weaknesses of the current agreements, and participants' opinions on carbon farming programmes. I conducted face-to-face semi-structured interviews with a small group of Māori landowners involved in commercial plantation forestry, hereafter referred to as forestry.

Carbon farming, or the provision of carbon dioxide $\left(\mathrm{CO}_{2}\right)$ credits, represents an opportunity for landowners to receive carbon credits from reforestation or afforestation. ${ }^{34}$ Under New Zealand's climate change mitigation policy, any new forests planted after January 1990 are potentially eligible to receive carbon credits under the New Zealand Emissions Trading Scheme (NZ ETS) (Karpas \& Kerr, 2011; Carver, Dawson \& Kerr, 2017). ${ }^{35}$ Due to the physical limitations of land resources and for historical political reasons, large areas of Māori freehold land have limited capacity for agricultural production and are better suited to conservation or forestry activities (Kingi, 2008a; Harmsworth, Tahi, \& Insley, 2010). Harmsworth (2003) estimates that at least $60 \%$ of Māori freehold land in Tairāwhiti (around 180,000 hectares) could be suitable for establishing forests eligible for carbon credits.

Māori communities are principally interested in whenua or land due to cultural imperatives, but also as a sustainable economic base for themselves. Harmsworth (2018) estimates that Māori freehold land is about 5\% of Aotearoa New Zealand's 26.8

\footnotetext{
${ }^{34}$ Afforestation refers to planting new forest species on land that has not previously been covered in forest (or has not been in forest for a very long time), whereas reforestation refers to planting trees on land that was previously forest.

35 An emissions trading scheme is a market-based instrument to limit GHG emissions from the sectors covered in the scheme. Under this scheme, a government fixes a regulatory limit on emissions. This translates into a market price, which creates an economic incentive to increase removals and decrease emissions. Participants from covered sectors are required to surrender a tradable emission unit for each tonne of emissions for which they are liable. Emission units can be allocated for free, bought from other participants, purchased at government auction, or earned by removal activities such as forestry (Cortés Acosta, Grimes \& Leining, forthcoming; Leining \&
} Kerr, 2018) 
million hectare total land area. The Te Ture Whenua Māori Act 1993 (TTWM) regulates the vast majority of this land, which has the legal status of 'Māori freehold land'. It is expected, however, that Māori land ownership will progressively increase as a result of post-Treaty settlements, and through purchases by Māori entrepreneurs (Harmsworth, et al., 2010; Dickson, Hensen, \& Madden 2009).

The TTWM explicitly references the Treaty of Waitangi and recognises that land is a taonga tuku iho or a treasure for Māori people that connects current generations with their ancestors and future generations. The TTWM promotes the retention of land in the hands of its owners, their whānau (extended family), and their hapū (sub-tribe). It also facilitates the use, development and control of Māori freehold land. To meet these objectives, the TTWM sets stringent rules that restrict the alienation of Māori freehold land, including sales or lease (Durie 1998).

As described in Chapter One, administration of Māori freehold land can be complex, for historical reasons (Bennion, 2009; Boast, 2008). There have been efforts to overcome absentee ownership and title fragmentation by reverting to collective ownership using the Māori land governance structures (including, Ahu Whenua trusts and Māori incorporations, two legal entities) as vehicles (Kingi, 2008a). These legal entities are also regulated under the TTWM. Each legal entity has a group of committee members or trustees elected by landowners. In this chapter, I refer to any of the members of these legal entities as the board or board members.

Studies about Māori landowners' experiences and opinions on carbon farming strategies are limited and sparse. Carswell, Harmsworth, Kerr, Kirikiri, and Turney (2002) evaluate the opportunities for Māori to participate in the provision of forest sink credits through regeneration of indigenous forest and develop a framework for Māori participation in $\mathrm{CO}_{2}$ sequestration projects. Cronin et al. (2012) discuss key issues of concern, and potential research topics for Māori and climate change in the land-based sector. They highlight that some Māori can face difficulties in effectively participating in the NZ ETS as it requires the understanding and application of highly technical scientific and legal knowledge, which some owners are in a better position to access and interpret than others.

Numerous studies have identified barriers that could prevent effective implementation of existing programmes for utilising forest carbon credits (e.g. Funk 2009; Funk, Field, Kerr, \& Daigneault, 2014; Dickson et al., 2009; Harmsworth, et al., 2010; Cronin, et al., 2012). Identified barriers include: concerns about retention of Māori 
landownership and control, commitment to long covenant periods (for example, perpetuity), liabilities, the complexity of participating in the NZ ETS, uncertainty about the future price of carbon credits or the monetary return for establishing forest, and structural attributes of governance institutions that shape decision-making processes. These factors influence whether and to what extent communities adopt market-based policy opportunities.

Based on a case study analysis, Bruce Small (2012) highlights lessons about engaging Māori communities in climate resilience planning. One important lesson mentioned is that researchers need to understand the principles of Te Ao Māori (Māori worldview), values, customs and protocols, in order to interact more constructively with communities. Bruce also mentions the importance of adequate timeframes for community organisations to consider, discuss and respond to matters.

I conducted face-to-face semi-structured interviews with a small group of Māori landowners who have been involved in commercial plantation forestry, hereafter referred to as forestry. The land blocks of these landowners have already been deemed eligible and registered in the NZ ETS. Therefore, interviewees have previous experience with carbon farming on their land in Tairāwhiti, the East Cape of Aotearoa New Zealand. Their experience can be summarised via two central decisions: switching to forestry and joining the NZ ETS.

According to interviewees' experiences, most of the land-use transitions into forestry occurred around 2001-2002, but the potential for carbon farming revenues did not influence these land-use decisions. Forestry has been an economic opportunity to access capital in the long term, while carbon farming is a relatively new experience, and is therefore considered a bonus that could provide revenue in the short term, before plantation harvesting, or in the long term if eligible areas are allowed to regenerate to native forest.

Two different forestry agreements were mentioned in the interviews: agreements signed directly with a forestry company, and agreements where landowners were part of a joint venture led by Ngāti Porou Forests Ltd (NPFL), a land management company. A strength of both agreements is that the forestry company that leased the land paid for the establishment cost of the forest (fencing, roads, planting the trees, and pest control). The contrast between them highlights the importance of trust in those providing capital. A local based land management company helps to create that trust. In terms of trading carbon units, several board members, who were part of the joint venture, agreed to lease 
carbon units to a carbon leasing company that holds the liability. Their experience is probably one of the first experiences of leasing carbon units in Aotearoa New Zealand. They did not contemplate possible changes in the carbon price when they negotiated, but these will be a consideration for future agreements.

Future research would be required to determine how representative the opinions found in this chapter are of those in the broader Māori community regarding their experiences with carbon farming.

The remainder of the chapter is structured as follows. Section 1 presents methodological details about the face-to-face interviews. Section 2 presents the results and discussions. Section 3 concludes the chapter.

\section{Face-to-face semi-structured interviews: methodology}

I conducted face-to-face semi-structured interviews to learn about the experience of carbon farming among five members of the Māori community. The interviews were conducted with a small purposeful sample (Patton, 2005) of four board members of Māori freehold land, involved in forestry and carbon farming in Tairāwhiti, and with the general manager of NPFL.

To engage with Māori communities in Tairāwhiti, a local Ngāti Porou researcher contacted board members to assess their interest in participating in the project and organised the interviews. A copy of the participant information sheet is in Document 2-1 in Appendix B. I conducted the interviews during May 2018. Each interview lasted up to an hour and was audio-recorded and transcribed. Ethics approval was granted by the Victoria University of Wellington Human Ethics Committee 0000025490. All respondents gave informed consent. A copy of the consent form is in Document 2-2 in Appendix B.

\subsection{Question guide}

I designed a semi-structured discussion guide, which focused on the nature of the decision-making process, the strengths and weaknesses of the current agreement, and opinions on carbon farming programmes. Each interviewee had a copy of the list of questions during the interview. I loosely followed the questions list, but also took the opportunity to follow up on the interviewees' answers and any new directions they prompted (Kvale \& Brinkmann, 2009). They were free to choose not to answer any 
question or ask to turn the recorder off at any time. Neither of these situations occurred. A copy of the question guideline is in Document 2-3 in Appendix B.

\subsection{Analysis}

The basic principles of qualitative inductive content analysis guided my analysis, which followed three main phases: preparation, organisation and report (Elo \& Kyngäs, 2008). All the interviews were transcribed verbatim and given a code to distinguish between them and maintain confidentiality. The analysis was computer-assisted using NVivo 12. I read all the interview transcripts to become familiar with the data collected. I then used open coding and grouped the list of categories under higher order headings (Vaismoradi, Turunen, \& Bondas, 2013). Finally, the results of the study were shared with peer reviewers and some interviewees, with whom I sustained repeated discussions until the interpretation was agreed upon.

\subsection{Study limitations}

This research used qualitative research methods with a small number of participants in order to explore issues regarding their carbon farming experience. I talked to people who have been deeply involved in decision-making processes concerning their land and other blocks in the area. Although this research provides rich data about the groups and individuals interviewed, it is a limited sample and therefore not suitable for generalisation. This may affect the representativeness of the results.

\section{Results of the interviews}

\subsection{The nature of the decision-making process}

Māori consider whenua (land) as tāonga tuku iho or a treasure that connects current generations with their ancestors and future generations. The utilisation of Māori freehold land should balance cultural and commercial imperatives (Dewes, Walzl, \& Martin 2011). Kingi (2013) lists three cultural constructs that influence the behaviour of Māori agribusiness organisations directly, affecting decisions relating to collaboration, investment, and diversification. These constructs are whakapapa (genealogy), whānaungatanga (tribal relations) and kaitiakitanga (the responsibility to nurture and 
care for the whenua through time and generations). The nature of the decision-making process regarding carbon farming is not an exception and is also influenced by cultural imperatives, such as a desire to look after the land for future generations, reciprocity with the land and community (older and new generations), and knowing the story of the land, among others.

That's one of the strategic goals of the plan [cultural values]. So around that, it's knowing the history of the area ... and looking after our kaumātua [older people] is another significant part ... Providing kaumātua grants, and making sure that that's sustainable, and looking forward to education grants as a part of giving back ... We've got fairly significant financial cash reserves, which our goal is to invest back in land, whether it's farming or horticulture, in the not-too-distant future to provide jobs for our people.

If you're going to take something out of the land, you really need to give something back. It's like anything else.

Our vision [NPFL's] is “Kei te whenua te waiu mo nga whakatipuranga kei te whai ake", which means the land will provide sustenance for future generations. So as long as we preserve our land, our people will always have something with which they can survive. So, we're all about making sure the land's protected.

According to the interviews, two key decisions were reached regarding carbon farming: transition into forestry and then joining the NZ ETS. Most of the land-use transitions into forestry occurred around 2001-2002 and were from sheep and beef or non-economic activities on the land. These land-use decisions were not influenced by the potential for carbon farming revenues. Participation in the NZ ETS began around 2011, and involvement relied significantly on a trustworthy agent who guided the board during this new arrangement. Three phases characterise historical decision-making about carbon farming: the evaluation phase, the transition phase, and the NZ ETS phase (see Figure 2-1, below). Going forward, access to rewards from the NZ ETS could influence the evaluation phase, so decision-making could be more iterative. 
Figure 2-1 Historical decision-making about carbon farming

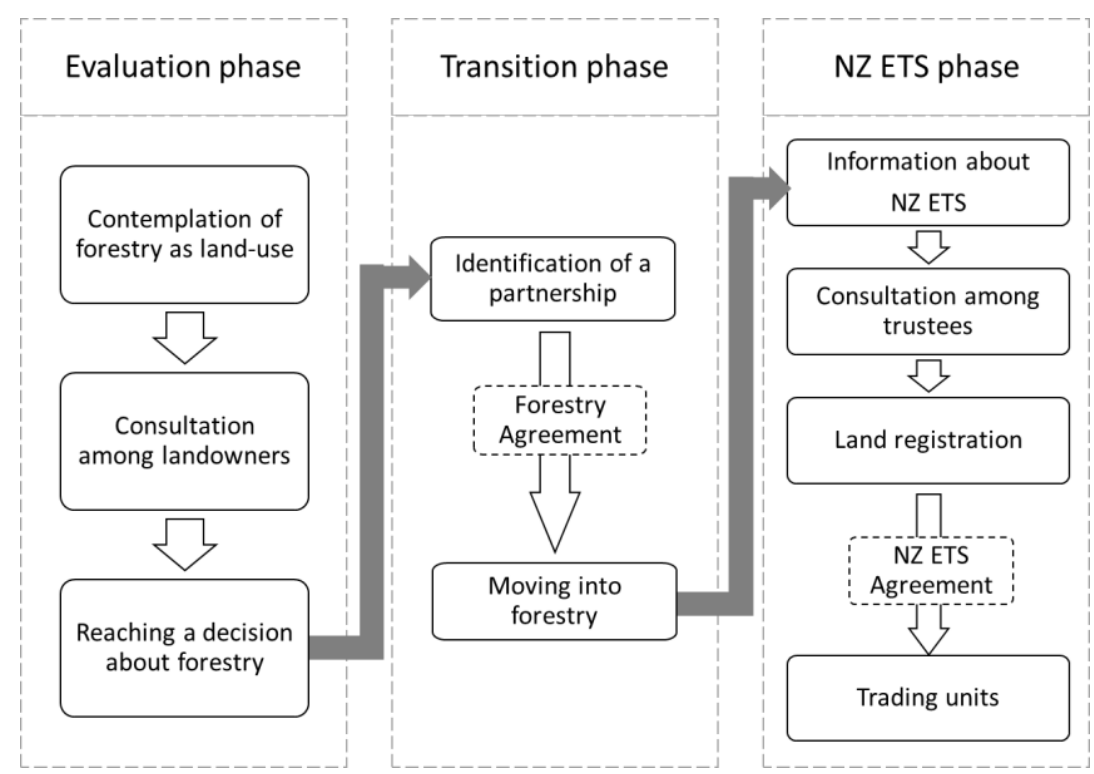

\subsubsection{Evaluation phase}

In the evaluation phase, landowners evaluated the possibility of using their land for forestry. Usually, a trustee suggested a possible land-use option. Information was then collected and the option evaluated. Once board members had enough information about the option, they consulted with landowners. Two drivers motivated the land-use change: land characteristics and landowners' desire for land to do well economically, as it is whānau land.

It was leased out to a farmer for a number of years, an agricultural pastoral farmer. Then, in 1993, the trust was set up to manage the farm in its own right. It wasn't a very successful farm, because of the isolation and the altitude, and because of the terrain, it's quite steep. And yeah, its position. The land isn't very fertile for agricultural and pastoral farming, for growing grass, and it has extremities of weather as well. Particularly in winter, it does get a lot of snow, due to the altitude.

So it [forestry] was a way of utilising the land. There's supposed to be some money coming out of it, which we may not see but our children and grandchildren will see.

Any possible land-use decision faced challenges in reaching an agreement. Cooperation and trust among the multiple owners are crucial components in making decisions. Because of absentee and multiple owners, it is a time-consuming process. 
Even though the board wanted to switch to forestry, this could only occur if landowners consented.

It was poorly farmed land, and we had to make a decision [all] those years ago, in which I was approached by two aunties to come on board. In that time, finding alternatives for the land and its usage to best be beneficial for us all. It was a time-consuming exercise. It took about eight years. Well, that's the protocols of Māori whenua. You have to have meetings, and give everybody the right of their reasoning as to what is best for the land.

We have trusts, we have committee members, we have sole owners, partnerships, but ultimately nothing happens on the land without the landowners' consent.

Another issue was resistance to change. New land-uses (such as forestry versus livestock farming) could be perceived as going against social norms or as having adverse effects on future generations. Although forestry provided an opportunity to access capital in the long term after harvesting, which they could then use to invest, concerns were raised about the effects of growing Pinus radiata pine on the soil properties of the land and on landowners' well-being. These concerns are related to the role of board members as kaitiaki (guardians) of the land.

We do have our concerns about the growing of the forestry, really we do, but we still went ahead with it. [Question: What concerns?] You know, like just the land no longer being as fertile as it [is], but then nothing was happening on the farm anyway.

The non-event of things happening on the whenua, we were confronted with a tough decision because one of the points raised by whānau is that you can't eat trees but you can eat cattle, or sheep.

\subsubsection{Transition phase}

The second phase of the process, the transition phase, has strong associations with evaluation. Although landowners decided to move into forestry, the transition did not occur immediately as they had to deal with issues associated with Māori land regulation. As described in Chapter One, Māori landowners are still dealing with the effects of the 
individualisation process of their customary land introduced during the 19th century by the Crown (Boast, 2004). One of these effects is that there are multiple owners who are not always aware of their ownership or are not always involved in the decisions because they live in other areas (Durie, 1998; Kingi, 2008a).

One of the board members interviewed, who has been deeply involved in the establishment of the joint venture led by NPFL, mentioned that it was essential to have strong leadership to handle identifying absentee owners, establishing a legal entity, or choosing a new group of board members for each of the 38 blocks of Māori freehold land that make up part of the joint venture.

\section{As you can imagine, there's been a lot of tracking people down, a lot of meetings, making sure that committees were set up right, and making decision-making processes that could all be mandated appropriately. A lot of that was a significant cost, because you've got lawyers going around to do that.}

Additionally, any agreement that involves Māori freehold land is subject to the TTWM, which imposes restrictions on the leasing of the land. The requirements can be hard to meet, adding an extra layer of complexity to land administration. For example, in incorporations, the majority of the committee members have to sign an agreement. In the case of trusts, all trustees must sign. This can be challenging, as trustees do not always reside in the area, or were appointed years ago and may be old, in poor health or deceased. ${ }^{36}$

\section{Forestry agreement}

Two different forestry agreements were mentioned in the interviews: some board members signed an agreement directly with a forestry company, while other landowners are part of a joint venture led by NPFL. Interviewees mentioned that before the forestry agreement they could not productively use their land because of capital constraints, so leasing the land was a way to cope with this constraint. A strength of both agreements is that the forestry company that leased the land paid for the establishment cost of the forest (fencing, roads, planting the trees and pest control), and it is now in

\footnotetext{
36 Once the Māori land governance structure is established, landowners elect board members. The TTWM requires them to meet compliance for processes related to land use administration, for example keeping their identification update.
} 
charge of forest maintenance and the transportation cost of the logs, which varies depending on the location of the land.

The landowners have come along with their land, have been capital constrained, and a funding partner has come in, so they've put all the money in, the landowners have put their whenua in, and therefore that was how the forest was able to be established.

In the case of the landowners who leased their land directly to a forestry company, the board had to deal with different challenges, such as landowners' expectations and weak governance structure. For instance, it was expected that elected board members would have the skills to administer the land and make decisions: however, these expectations were not always met.

You really need a management committee who are actually based in the area. At the moment, our management committee's made up of one who lives in Wellington, one who lives in Taupō, and another one in Whakatāne. They don't really know what's happening on the ground. So they come up here for meetings, but they don't, really don't know the culture of what's happening round home. People have elected them onto the committee because they seem to have the skills, but the skills really - it's not only skills you need. It's really you need the homegrown people who know ... how the land is and how everything operates.

In contrast, NPFL provided information and managed the agreement process. NPFL established and managed a forestry joint venture between landowners and forest investors. The last joint venture involved Hansol New Zealand contributing money and landowners contributing land. Trust, strong leadership and assistance during the negotiation of the agreement were identified as significant strengths of the agreement with NPFL. I was told that landowners leased the land because they trusted NPFL, who are also from Tairāwhiti, which creates a sense of belonging.

We have 38 blocks in a joint venture, and those 38 land-blocks actually own our company. So, when we're doing a lot of this work 
[administrative work], we're doing it for the owners of the company anyway. So, it is administration heavy, but it's what the owners require.

My knowledge of it [forestry] is basically not terribly much. All I know is I can see something happening on our land and because forestry is being funded by somebody else, we can do that. If we had to do it ourselves, there's no way we could do it.

Questions around perceptions about restrictions on access to their land or effects on employment associated with forestry were not part of the question guideline. However, opinions about these issues were brought up. Some interviewees mentioned that when forest operations are occurring, access to the land block is restricted to both landowners and recreational users for health and safety reasons. Landowners can access their property for hunting and tramping purposes during the weekends. This requires them to fill in a permit form prior to the date they would like to access the property. My understanding is that this permit form is from NPFL.

In addition, some interviewees argued that forestry had an adverse effect on employment in the area, while others thought it could be an opportunity for employing people from their community. Some interviewees had expectations that new jobs would be created, but it seems that these jobs were temporary and resulted in the disappearance of previous full-time jobs. Expectations about jobs are important and can influence future decisions. Achieving potential employment gains requires training, which requires time.

The company wants to hurry up and establishes this [mānuka trees], so they haven't got the time to train any of the locals. So it's okay, we'll just bring people in that can hurry up and get all the drains done and the irrigation done, and everything, and plant ... No, no we won't need the locals. We haven't got the time to train them ... which disappoints me with the management committee.

The change from pastoral farming to forestry in [the station] has had a negative effect on employment. Four full-time workers were employed on the farm where as now with forestry there are no resident workers. Tree pruning and thinning regimes happened in the early days but since those jobs were completed, with forestry gangs from town, there has been little employment activity specifically [on the station]. The 'little 
activity' referred to includes some occasional possum trapping and forestry measurement.

My understanding, and one of the reasons that we went with Hansol was that Ngāti Porou people were going to be employed in all aspects of that. My understanding is that those ones who did the planting did, but it was contractual stuff.

\subsubsection{NZ ETS Phase}

The board relied on a trusted agent to guide them through the process of registering their land in the NZ ETS and to assist in the process of selling or leasing the units and understanding their liabilities. ${ }^{37}$ Several factors help explain this. First, greenhouse gas (GHG) emissions are an abstract and relatively new concept that is not part of Te Ao Māori. Second, the NZ ETS is a relatively new scheme that is still difficult to comprehend, as it requires a reasonable understanding of legal requirements, information about land eligibility and carbon units generated by the trees on the land, among other issues.

Just trying to get the landowners to understand what the ETS is ... it's quite complicated, and telling them that someone would pay them for air. I got a lot of looks and a lot of shakes of the head. So just trying to get the understanding and I'm not the best drawer, but I took a little whiteboard along and tried to draw little trees absorbing carbon from factories putting carbon dioxide in the atmosphere.

In this phase, clear information and assistance were critical to enable the decision to join the NZ ETS. Specifically, for the land block that is not part of the joint venture, I was told that the land was registered in the NZ ETS, but the board could not trade or lease any carbon units. There are explanations for this situation: a lack of information, misunderstanding of the aim of the NZ ETS and the options available for leasing or trading the carbon units, and difficulties in having board members make a decision. The trustee interviewed expressed interest in knowing more about how to get payments for carbon units, associated with either forestry or native trees. Their experience illustrates

37 Carswell et al. (2002) provide an example of two contracting mechanisms: a sale of $\mathrm{CO}_{2}$ credits to buyers or a year-by-year leasing agreement designed for buyers who pay for continuing to protect the carbon stored. 
the importance of having guidance during the negotiation process in order to comprehend the crucial points of the whole negotiation process. In addition, trust in the person who acts as the agent for the board is critical.

The committee had actually these people come around talking about carbon credits and Emissions System. But the story that they sold to our people wasn't very clear at all ... Said you've gotta have, you've gotta claim for carbon credits, you know, otherwise when you cut the trees you must grow some more trees, and you must do this and must do that, and here's the credits and you must register before 1990, and there were a lot of musts, musts, musts, musts, but there weren't any clear indications of what really was the value of registering for carbon credits.

In contrast, some of the land blocks that are part of the joint venture have had success joining the NZ ETS and leasing carbon units. The following section describes their experience in more detail.

\section{NZ ETS agreement}

Participation in the NZ ETS started around 2011. Although board members were slightly dubious about the NZ ETS, they agreed to be part of the scheme because NPFL led the negotiation process of leasing the carbon units. At the time of the interview they had already received payments.

We [NPFL] managed all the legal work, got all the leases drawn up. We had 34 blocks that qualified for the post-89 land. And 31 of them signed the lease ... Of those three that didn't sign, two only had 10 hectares; one had a deceased person and it wasn't worth the effort to replace the person in the timeframe ... The other 10 hectares, they had a trustee issue. The trustees weren't getting on with each other. And we made the decision that it wasn't worth trying to get them to get their 10 hectares into the lease. And we had one big block that didn't sign, and again, that was a trustee issue. Trustees trying to oust each other off the trust, and that's actually still in Māori Land Court.

The decision to move into forestry was motivated by an economic opportunity to access capital in the long term. Joining the NZ ETS and receiving payments for carbon 
units are considered a bonus because it provides revenues in the short term, before plantation harvest. These payments represent a new opportunity for landowners to reinvest in the land (such as, buying beehives or maintaining the roads) or to allocate resources to other businesses apart from their land.

They're all existing forest owners, and then the ETS came along which meant basically a bonus for them because most of the forests were established for wood, but with the ETS coming along there was an opportunity for our landowners to benefit from carbon. So, we presented the different ways in which they could benefit from carbon and then they made the decision on how they wanted to.

We were sitting on our hands, right? With money invested from the sale of stock, you know, and other assets in financial portfolios. So each year we were reliant on what the share-market was doing, and what bonds were doing and so forth, in order to get income to operate the Trust, and still trying to grow that portfolio. So then to get a carbon cheque each year of - after tax - around $\$ 150,000$. It is quite a significant amount for doing nothing different.

The agreements through NPFL state that the carbon leasing company holds the liability, rather than the landowners, as the carbon units were leased rather than sold.

I'm quite pleased with it [the agreement]. The biggest thing is minimising risk to the land and the landowners. So, we've achieved that. Potentially we could be selling carbon at a higher price, but then the liability is on us ... When I say us, I mean whānau, the landowners, us, the liability would be on us to pay those units back prior to harvesting. So, I'm quite happy that we're getting quite a good return for our carbon whilst having no liability to pay it back.

One issue with contracting is the balance between short- and long-term returns. The price of the annual payment per tonne of $\mathrm{CO}_{2}$ was fixed at the beginning of the lease. ${ }^{38}$ However, future fluctuations in the price should be also considered as part of the negotiation. The negotiation took place when the price was low and it subsequently

38 The leases are until just prior to harvest. 
increased. This situation was perceived as unfair and has created resistance to future negotiations.

The price increases above $\$ 20$ per unit. So, what does that look like? It has been staggered up, and it sits here, but now that has gone over, what does that look like? So that's where we're at. So, I mean, it's gone up. As I say it was around $\$ 2$ when we first entered this, and so that seemed a long way away, so I don't know if there was enough consideration of this part here. Because that's basically it. There's not a lot more detail than that.

\subsection{Opinions on forestry and native trees as an option for future land-} use

The landowners involved in the joint venture are in a different position now than 20 years ago before they converted to forestry from uneconomic farming activities. Most have paid their debts and are in a better financial position. The second rotation on these blocks will be in about eight to nine years. Some board members are considering whether they would like to continue in forestry (second rotation) or move into another tree species (including native trees such as mānuka). The financial returns of other activities may be influential, but before making any final decision, the board needs to consult with the landowners. This consultation usually occurs at the Annual General Meeting (AGM).

A lot of our landowners, well, the big question they face is: what do we do after harvesting? Once their investment's in place, and they're waiting to see the financial result of their investment, and then they'll determine whether they go again in exotics or pine, or whether they go to something like mānuka. Today it seems to be the two options that they're seriously considering.

The block of land that is not part of the joint venture is switching into a mānuka plantation. However, the trustee interviewed suggested that there are disagreements about this choice because it is a long-term contract and landowners were not consulted.

A mānuka company [name changed for keeping confidentiality] has now got a contract with [the station] too and are planting mānuka all on 
either side, which is not going down very well with the locals, because the locals didn't want ... That was good farmland, and the locals didn't want to go into a mānuka company.

Mānuka is becoming an attractive economic activity in the area because landowners can gain profits from honey, oil production and tourism. However, for a long time, having the land in mānuka or kānuka was considered a signal that landowners did not have money to use their land. A transition to mānuka forestry requires overcoming this mindset, evaluating the benefits associated with mānuka and comparing them with current land-use activity. Kānuka is not yet seen as a profitable land-use activity.

Everyone is signing up to grow mānuka. When we were young, my father was one of the ones who helped to cut mānuka on [the station] so they could have more area for grass and now they want to plant it in mānuka. We've done the full circuit.

Some interviewees mentioned areas where forestry should not be planted. I was told these areas are isolated, too steep and with difficult access. In some cases, these characteristics represent an opportunity for planting or encouraging natural regeneration of native forest.

\subsection{Opinions on carbon farming programmes}

The carbon cycle is a new concept in Te Ao Māori, thus it may be met with mistrust or scepticism.

[Question: What is carbon farming for you?] It is a payment for nothing.

We get paid for growing forestry while the rest of the world screw-up.

I observed high levels of misunderstanding and miscommunication about carbon farming and the NZ ETS. The NZ ETS is considered too technical and political. The topic sounds complex and complicated terminology can be a barrier for landowners to decide to join the NZ ETS. Even though landowners involved in the joint venture have received payments for carbon farming, not all of them associated these payments directly with the NZ ETS. NPFL played a critical role in registering the land in the NZ ETS and leasing the carbon units. This experience is a good example of the importance of a trustworthy and credible source of information to cope with relatively new schemes. 
[After discussing his opinion on the NZ ETS] This carbon credit thing is that we never envisaged getting any money at all, until we got the harvest. Now we have x amount of dollars, my head has got to change, and my thinking has got to change, because obviously there are other mechanisms at play here.

I also asked about other forestry support strategies from the government, such as the Afforestation Grant Scheme (AGS), the Permanent Forest Sink Initiative (PFSI), and the Erosion Control Funding Programme (ECFP). These questions were designed to elicit landowners' opinions about these programmes, rather than verify their participation. Before talking to the landowners, I was briefly told that some land blocks that were part of the joint venture had used some of these programmes, but I did not know which blocks. Many of the landowners, however, were unfamiliar with these strategies. A lesson for future interviews is to have precise information on these opportunities to share with interviewees. Additionally, it may be useful to become better informed about the programmes in which each land block is involved.

Although in this chapter I do not aim to evaluate the NZ ETS rules, it is important to clarify that it is only post-1989 forest that can earn units. This ruling is part of initiatives that incentivise increased planting and change people's behaviour (Carver et al., 2017). Some interviewees question why pre-1990 native forest - and all pre-1990 forest cannot earn units for forest management activities that increase carbon stocks. Their questioning has led to doubts about the aim of carbon farming.

I still can't understand, because you've got significant forests that have been, native forest that have been sequestering since the beginning of time. And at three and a half thousand hectares, how can we not get anything for that? I can't understand that. That is something that the government is getting for nothing.

\section{Conclusions}

Two different carbon farming experiences were identified in the interviews: a joint venture led by NPFL and an agreement signed directly between landowners and a forestry company. Although in both instances the forestry agreement was signed, only some landowners in the joint venture agreed to lease carbon units. NPFL is an example 
of how important having leadership and trustworthy sources of information is in supporting the decision-making process.

Decisions about the possible utilisation of Māori freehold land can take time, as decision-making processes involve numerous steps and the consideration of potential effects on future generations. One interviewee mentioned that deciding to go into forestry took them about eight years. Other matters that affected the decision-making processes were landowners' expectations and governance issues. Involving more Māori communities and organisations in carbon farming, necessitates allowing adequate time frames for engagement that give space to deliberate, discuss and respond. Rushed decision making could lead to riskier decisions that may not be supported by landowners, given their role as kaitiakitanga (the responsibility to nurture and care for the whenua through time and generations) and long-term implications of the decision. Elements that may help smooth the path for considered decision making include building trust, providing information that helps inform decision making, and making allowance for consideration of the potential implications on the land and people. Additionally, it is important to address expectations, such as potential employment gains.

NPFL has played a key role in informing and supporting Māori communities to reach decisions about joining the NZ ETS. Although the NZ ETS is now 12 years old, it is still challenging to understand how to join and receive payments for carbon units. A better understanding of Te Ao Māori and where carbon emissions fit into a Māori world view could help outsiders interact more constructively. It would be useful to work on materials that build the carbon cycle into Māori understanding. This work should be done constructively with Māori communities.

Forestry and carbon farming have given landowners access to capital. The decision to move into forestry was motivated by an economic opportunity to access capital in the long term, while payments for carbon units provide revenues in the short term, before plantation harvest. These payments can be reinvested in the land, but can also be allocated to other business activities and used to support the community.

The agreements for payments of carbon units discussed in the interviews were about exotic forestry. Some interviewees expressed their desire to plant native trees. Although the NZ ETS can support the establishment of native forests, nobody mentioned this option. It seems to be a perception that carbon units are only for exotic forest, rather 
than native trees. This may be associated with questions about why pre-1990 forest does not get carbon units, but new plantations do.

\subsection{Directions for future research}

This chapter reflects a first effort to explore issues regarding carbon farming experience on Māori freehold land. Future research could build on these findings by consulting a wider range of Māori communities, to determine the prevalence of various perceptions and opinions. Some ideas for future research are outlined below.

(1) The joint venture led by NPFL is a successful example of moving into forestry and becoming involved in carbon farming. I would recommend continuing observation and research on this case study to keep learning about their experiences and to help develop strategies to expand Māori landowners' interest in carbon farming.

(2) It could be useful to conduct a SWOT analysis to identify strengths, weaknesses, opportunities, and threats of contracting mechanisms (for example, sale and lease contracts) that are already signed. This analysis could provide further information about the liability, payments, and concerns about future revenues, among other things.

(3) It could also be useful to carry out a study about the socio-economic implications for Māori communities of changes in farming or other intensive land use, for example, the effects on local employment and co-benefits associated with carbon farming.

(4) Researching how several misunderstandings have developed (e.g. land eligibility criteria, calculation of carbon credits, liabilities, among others), and consulting with Māori about ways to embed better understandings of the NZ ETS and the carbon cycle into Te Ao Māori may be a point for future research also. 



\section{Chapter Three. Land-cover choices in Aotearoa New Zealand: do Māori land governance structures make a difference?}

In the previous two chapters, I set out my understanding of the connection between the land and Māori, and how this connection has been altered by interactions between Māori and the Crown. In Chapter One, I discussed three case studies of Māori farms administered by different governance structures and explored how these structures influence decisions on land utilisation and management. In Chapter Two, I explored the nature of the decision-making process associated with choosing to go into commercial forestry and carbon farming. As a general conclusion, I found that the Māori land governance structures studied - Māori incorporations and Ahu Whenua trusts - have facilitated decisions on the development and use of the land administered for commercial purposes. Simultaneously, board members and farm managers may balance these purposes with cultural, social and environmental imperatives. In this chapter, I extend the qualitative analysis by quantitatively measuring the relationship between Māori land governance structures and land-cover choices.

Research into decisions on utilisation of rural land in agricultural and forestry activities has been motivated by socio-economic and environmental implications. I concentrate my attention on the environmental implications of anthropogenic activities on land use and land cover. ${ }^{39}$ Understanding the different drivers for decisions on land cover and land use (see for example, Geist et al., 2006; Lambin et al., 2001; Stavins \& Jaffe, 1990) can help to identify areas where effective public policies regarding climate change mitigation can be developed.

Research on land use requires more detailed information, which is not always publicly available or is costly to collect. For those reasons, it is common to find in the literature that land cover is used as a proxy for land use. I recognise the difference

39 'Land cover' can be defined as "the attributes of the Earth's land surface and immediate subsurface, including biota, soil, topography, surface and groundwater, and human (mainly builtup) structures" (Lambin, Geist, \& Rindfuss, 2006, p. 4). 'Land use' can be defined as "the purposes for which humans exploit the land cover. It involves both the manner in which biophysical attributes of the land are manipulated and the intent underlying that manipulation" (Lambin, et al., 2006, p. 4). 
between land use and land cover, but, for simplicity, I use the term 'land-cover choices' to refer to studies on either land use or land cover. Furthermore, depending on the data available, it is common to find in the literature that analysis is done for a specific moment (hereafter land-cover shares) or comparison across time (hereafter land-cover transitions).

In the literature, scholars have attempted to theoretically and quantitatively explain the determinants of land-cover choices. In economic theory, for instance, decisions on land utilisation have their roots in bid-rent theory, predominantly in David Ricardo's and Johann Heinrich von Thünen's work. Ricardo (1821) argues that, due to soil fertility differences and land scarcity, the rent charged on the highest land quality is based on its relative advantage over the lowest land quality. Von Thünen (1966) introduces the influence of spatial location, into models of agricultural land; for example, the distance to markets and transport costs.

Numerous quantitative studies prove that land-cover choices are shaped by landowners' preferences and characteristics of the land (Lambin et al., 2001; Nelson, Harris, Stone, Barbier, \& Burgess, 2001). Landowners' preferences can be influenced by access to land as a productive source (for example, a land tenure system or property rights) (Hyde, Amacher, \& Magrath, 1996; Leonard, Parker, \& Anderson, 2020; Parker, 2004; Schneider, 1993), socio-economic features (expected profits or cultural preferences) (Lubowski, 2002; Lubowski, Plantinga, \& Stavins, 2008) and public policies (incentives or constraints) (Heilmayr, 2015). Characteristics of the land can be divided into geophysical (soil type, climate or irrigation) (Plantinga, 1996) and location of the land (access to markets or infrastructure or roads) (Chomitz and Gray, 1996).

In Aotearoa New Zealand, quantitative studies have been conducted to explore how land-cover choices, alongside decisions on land-use intensity or adoption of land-use practices, respond to economic, regulatory and environmental changes. ${ }^{40}$ For instance, Todd and Kerr (2009) found some evidence of the relationship between land-use changes, slope and land use capability. Kerr and Olssen (2012) estimated the effect commodity prices have on aggregate land-use changes and found that land use responds

\footnotetext{
${ }^{40}$ Anastasiadis et al. (2013) provide a brief description of the most relevant land-use models that have been developed for the country. Cortés Acosta et al. (2019) provide a comprehensive literature review on barriers to the adoptions of technologies and practices in the context of pastoral farming in New Zealand and Australia.
} 
slowly to changes in economic returns. Dorner and Hyslop (2014) found a positive effect of land sales on land-cover changes from pasture into forestry. ${ }^{41}$ Timar $(2011 ; 2016)$ estimated the relationship between Māori freehold land status and rural land-use choices, after controlling for socio-economic and geophysical factors. He concluded that on average Māori freehold land is more likely to be in low-capital intensive uses than general land. Apart from Timar's work, Aotearoa New Zealand studies have not explored quantitatively how Māori landowners respond to economic, regulatory and environmental changes. ${ }^{42}$ My work extends his by analysing the relationship between Māori land governance structures and land-cover choices in 2012. Furthermore, I analyse land-cover transitions between 1997 and 2012.

As discussed in Chapter One, the two main land statuses (or private land) can be divided into general and Māori freehold land..$^{43}$ General land is privately owned land that is not subject to the special restrictions of Māori freehold land, but it can be owned by Māori. Māori freehold land, under collective 'ownership', has a complex ownership arrangement based on customary regime and ancestral connections. Furthermore, the Te Ture Whenua Māori Act 1993 (TTWM) promotes the retention, use, development, and control of Māori freehold land in the hands of its owners, their whānau and their hapū. Throughout history, different alternatives have been used to facilitate decisions on Maori freehold land. Today, the TTWM provides a scheme for the operation of the Māori land governance structures.

In this chapter, I aim to contribute to the understanding of the drivers of rural landcover choices in Aotearoa New Zealand, by quantifying the relationship between Māori land governance structures and rural land utilisation. Specifically, I explore four questions: was Māori freehold land less likely to be used in capital intensive activities in

${ }^{41}$ I do not include land sales as a variable in my analysis because Māori freehold land cannot easily be sold. Dorner and Hyslop (2014) included Māori freehold land as a control variable in their analysis, however, the coefficient estimates are not statistically significant.

42 Different studies have explored the potential economic gains from bringing under-utilised and 'unproductive' Māori freehold land into the productive agriculture sector; for more information, see Daigneault, Wright, and Samarasinghe, 2015; Pricewaterhouse Coopers, 2013, 2014a, 2014b, 2014c; Te Puni Kōkiri, 2014a, 2014b. However, in these studies are not clearly discussed that Māori may choose not to develop land economically for cultural reasons.

43 By private land I refer to any land block under either of the two main land statuses - general and Māori freehold land. This is a way to differentiate these land statuses from Crown land. 
2012 in comparison with general land, after controlling for land characteristics? Did Māori land governance structures influence this likelihood? Was Māori freehold land less likely than general land to make an active transition between 1997 and 2012? Did Māori land governance structures influence these transitions? By active transition, I mean a positive land-cover change that involved any sort of investment. I assume that active transitions are pasture to forestry, forestry to pasture and scrub to pasture or forestry.

For the analysis, I created the New Zealand Private Rural Land (NZPRL) dataset. The NZPRL dataset contains panel information of rural land cover for 1997 and 2012 and cross-sectional characteristics of the land. I use land-cover as a proxy for land use, because of limitations in publicly available data. I assume that the level of capital intensity decreases from horticulture, pasture, forestry and scrub to indigenous forest. ${ }^{44}$ The set of characteristics of the land includes location and geophysical conditions and two dichotomous variables to identify whether the land is Māori freehold land or general land; and, within Māori freehold land, whether a Māori land governance structure administers the land.

The channels through which Māori land governance structures can influence decisions on land allocation are not obvious. As presented in Chapter One and Chapter Two, because Māori freehold land is considered a basis of identity, the behaviour of the board on decisions about land utilisation or management needs to maintain a sense of balance in the midst of differing socio-cultural, environmental and economic interests (Cortés Acosta et al., 2019; Dewes, Walzl, \& Martin, 2011; Durie, 1998; Kingi, 2013; Mead, 2016). Also because governance structures are not chosen or randomly assigned; it is not easy to claim direct causality of the effects of Māori land governance structures; therefore, I interpret the results carefully, seeing them as a demonstration of correlation rather than causation.

My results find that for Māori freehold land, there is a positive relationship between having Māori land governance structures in place and the allocation of land in 2012 in forestry and a negative association with pasture. From 1997 to 2012 I found that Māori land governance structures are associated with more transitions to forestry and fewer transitions into scrub. However, my results do not provide enough evidence to assert

\footnotetext{
${ }^{44}$ I recognise that this assumption can be debated as dairy may be more capital intensive than forestry, but it is not necessarily the case for sheep and beef.
} 
that Māori land governance structures can help to stay in pasture (or move to pasture), which means that it is not possible to claim that Māori land governance structures motivate active transitions.

The remainder of the chapter is structured as follows. Section 1 presents the conceptual framework used for analysing decisions on land utilisation. Section 2 presents the data description. Section 3 presents the methodology used for the quantitative analysis. Section 4 presents the econometric results. Section 5 concludes the chapter.

\section{Decisions on land utilisation: a conceptual framework}

In this section, I present a conceptual framework associated with land-cover choices. This conceptual framework motivates the analytical framework presented in Section 3. For my analysis, I separate these choices into land-cover shares and land-cover transitions. Land-cover shares refer to land allocation to certain land-cover in a specific period of time. These allocations can be result of decisions over a long period of time. Land-cover transitions refer to changes (or conversions) among different land-cover alternatives between two points in time.

Consider price-taking landowners facing the choice of allocating a unit of land $i$ with homogeneous land quality among a set of land-cover alternatives $d \in\{j, k, l\}$. I assume that landowners have effective control over their land and can make decisions about any possible land allocation. I also assume that landowners aim to maximise their utility $\left(u_{i d}\right)$ when allocating land to a certain land-use alternative and are risk neutral. This allocation may be driven by profits $\left(\pi_{i d}\right)$ and amenity values $\left(\omega_{i d}\right){ }^{45}$ Then, landowners' utility can be expressed as $u_{i d}=\pi_{i d}+\omega_{i d}$.

Suppose the annual profit per unit of land $i$ in the $d$-th land-cover at time $t$ is $\pi_{i d t}$ and the profit-specific discount rate is $r$. This profit-specific discount rate captures the opportunity cost of capital, which is affected by capital constraints. The present value of a stream of profits can be expressed as Equation [3-1].

\footnotetext{
45 Amenity values, as defined in the New Zealand Resource Management Act 1991, are "those natural or physical qualities and characteristics of an area that contribute to people's appreciation of its pleasantness, aesthetic coherence, and cultural and recreational attributes".
} 


$$
\begin{gathered}
\Pi_{i d}=\sum_{t=1}^{\infty} \frac{\left(\pi_{i d t}\right)}{(1+r)^{t}} \\
\mathrm{~d} \in\{\mathrm{j}, \mathrm{k}, \mathrm{l}\}
\end{gathered}
$$

Some studies have indicated that investment in Māori freehold land can be negatively affected by capital constraints (Daigneault, Wright, \& Samarasinghe, 2015; Kingi, 2008a; Ministry of Agriculture and Forestry, 2011; West, Journeaux, Wakelin, \& Kingi, 2016). Additionally, the TTWM establishes strict rules on the alienation of Māori freehold land, so using this land as collateral can be difficult. ${ }^{46}$ I hypothesise that, relative to general land, Māori freehold land is less likely to be in capital intensive activities (such as horticulture, pasture and forestry), because their profit-specific discount value is higher, so the present value of profit is lower. Their profit-specific discount rate reflects capital constraints, which can be associated with restrictions to use Māori freehold land as collateral, as well as any other limitations on access to finance markets relative to those operating on genera land. Given the capital constraints, landowners might expect to have high returns on their capital they do employ. ${ }^{47}$

However, as I discuss in Chapter One, Māori land governance structures are often commercially successful. Their boards can use different assets to support investments, such as land blocks of general land. It is possible, therefore, that having a Māori land governance structure in place increases the likelihood of allocating land into capital intensive activities, relative to Māori freehold land without structure.

For Māori, amenity values $\left(\omega_{i d t}\right)$ also play a key role in the decision to allocate a unit of land $i$ in the $d$-th land-cover. Amenity values capture cultural preferences and other benefits which are not typically included in financial analysis or profit maximisation considerations. For example, this could include the protection of a certain area in indigenous forest because of landowners' perceived roles as kaitiaki (steward) of a specific water source for future generations or motivated by rongoā rākau (native plantbased medicines). I hypothesise that because of amenity values, Māori freehold land is more likely to be in scrub or indigenous forest. This assumes that scrub is a conscious decision to retire the land as a first stage for reverting into native forest.

\footnotetext{
${ }^{46}$ As I discuss in footnote 32, the TTWM permits alienation with the consent of landowners or beneficiaries.

47 For more discussion about the choice of the discount rate as a rate of time preference or the consumption discount rate, see Heal (2008).
} 
The amenity-specific discount rate $\delta$ captures an intergenerational interest based on a sustainability criterion. Tietenberg and Lewis (2014) define the sustainability criterion as "at a minimum, future generations should be left no worse off than current generations" (p. 98). Equation [3-2] shows the present value of a stream of amenity values.

$$
\Omega_{i d}=\sum_{t=1}^{\infty} \frac{\left(\omega_{i d t}\right)}{(1+\delta)^{t}}
$$

As described in Chapter Two, considerations for future generations and potential economic opportunities, such as allocating land to forestry activities, can motivate the interest of having a Māori land governance structure in place that facilitates decisions on allocating land into forestry as an opportunity to access capital in the long term. Hence, having a Māori land governance structure in place could increase the likelihood of allocating land into forestry, relative to land without structure.

Under a utility maximisation framework and considering time as a factor, the landowners' problem consists of choosing the land-cover alternative that offers the greatest present value of utility after comparing the relative utility of other alternatives. Note that each discount rate measures different attitudes towards the land - economic and amenity values. The present value of utility of choosing option $d$ can be expressed as Equation [3-3]:

$$
U_{i d}=\sum_{t=1}^{\infty} \frac{\left(\pi_{i d t}\right)}{(1+r)^{t}}+\sum_{t=1}^{\infty} \frac{\left(\omega_{i d t}\right)}{(1+\delta)^{t}}
$$

Māori landowners would allocate land to activities that are more capital intensive to maximise their profits if economic interests are sufficiently significant, and they do not face capital constraints or high levels of risk aversion that give them a high profit discount rate. But, if amenity values are predominant, it is more likely that Māori freehold land would be allocated to scrub or indigenous forests, assuming that scrub is the first stage for reverting into native forest.

Any allocation of land observed in a specific time period is the result of a series of decisions made in the past, which may have involved a series of transitions among different land-cover alternatives.

I suppose that the current land use is $d \in\{j, k, l\}$ and landowners consider switching to the alternative land-cover $a \in\{j, k, l\}$ with $d \neq a$. The present value of the utility of the alternative $a$, given that current use is $d$, can be expressed as Equation [3-4]. 


$$
\mathrm{U}_{\mathrm{ida}}=\Pi_{\mathrm{ida}}+\Omega_{\mathrm{ida}}-\mathrm{C}_{\mathrm{da}}
$$

Conversion costs $\left(C_{d a}\right)$ from switching from $d$ to $a$ are positive. These costs capture direct financial costs (such as building a dairy shed or planting trees) and decision costs, which capture the complex ownership structure of Māori freehold land (that is, any costs associated with the decision-making processes such as the time taken to agree with other landowners). The higher conversion costs are, the lower is the likelihood of making any land-cover transition. This observation may lead to the hypothesis that Māori freehold land is less likely to make an active transition, relative to general land. By active transition, I mean a positive land-cover change that involves any sort of investment, such as, moving from pasture into forestry (or vice versa) or moving from scrub into pasture or forestry.

As discussed in Chapter One, Māori land governance structures have been used to facilitate decision-making processes. Having a Māori land governance structure in place might be a way to deal with these conversion costs. It suggests that Māori freehold land with structure is more likely to make an active transition than land without structure.

Substituting Equation [3-1] and Equation [3-2] into Equation [3-4], the present value of utility for choosing alternative $a$ when starting in alternative $d$ is:

$$
U_{i d a}=\sum_{t=1}^{\infty} \frac{\left(\pi_{\text {idat }}\right)}{(1+r)^{t}}+\sum_{t=1}^{\infty} \frac{\left(\omega_{\text {idat }}\right)}{(1+\delta)^{t}}-C_{d a t}
$$

To decide on any possible transitions, landowners compare the utilities presented in Equation [3-3] and Equation [3-5]. The transition from $d$ to $a$ will happen if the benefits from that conversion are higher than the costs. Equation [3-6] represents the landowners' decision rule.

$$
\left[\sum_{t=1}^{\infty} \frac{\left(\pi_{\text {idat }}\right)}{(1+r)^{t}}-\sum_{t=1}^{\infty} \frac{\left(\pi_{\text {idt }}\right)}{(1+r)^{t}}\right]+\left[\sum_{t=1}^{\infty} \frac{\left(\omega_{\text {idat }}\right)}{(1+\delta)^{t}}-\sum_{t=1}^{\infty} \frac{\left(\omega_{\text {idt }}\right)}{(1+\delta)^{t}}\right]>C_{d a t}
$$

According to this rule, landowners select the land-cover that maximises the present value of the stream of profits and amenity values after considering conversion costs. Following Lubowski (2002) and assuming static expectations - landowners only plan one transition at a time (Jaffe \& Stavins, 1995). The decision rule can be re-written as:

$$
\left[\frac{\pi_{i d a}}{r}+\frac{\omega_{i d a}}{\delta}\right]-C_{d a}>\left[\frac{\pi_{i d}}{r}+\frac{\omega_{i d}}{\delta}\right]
$$

Note that conversion costs vary both by the initial land-cover $d \in\{\mathrm{j}, \mathrm{k}, \mathrm{l}\}$ and the final land-cover $a \in\{\mathrm{j}, \mathrm{k}, \mathrm{l}\}$ with $d \neq a\left(C_{d}=0\right)$. 
Land allocation observed for one specific moment in time represents a stationary state. In this case, I assume that the dynamic forces that influenced decisions on land utilisation over a long time period have settled, including conversion costs. Thus, the conversion costs are effectively equal to zero.

I expect to observe no change or a passive transition into scrub in Māori freehold land, relative to general land if Māori landowners face capital constraints and high conversion costs. As discussed in Chapter One, Māori land governance structures can help to overcome capital constraints and facilitate decisions, for example, using the land for commercial purposes. I hypothesise that Māori freehold land with structure is more likely to make an active transition than Māori freehold land without structure.

However, if amenity values are predominant, transitions of Māori freehold land to forestry or scrub are more likely to occur. In this case, I assume that scrub is a first stage for reverting the land into native forest. Distinguishing these hypotheses on transitions into scrub requires further information about landowners' aspirations, which unfortunately I do not have.

The conceptual framework described in this section suggests that decisions on land allocation aim to maximise the present value of the stream of profits and amenity values after considering the conversion costs. Although this conceptual framework provides insights, its application relies on observable data.

\section{New Zealand Private Rural Land dataset}

In this section, I describe the data sources used and the data process I followed for creating the New Zealand Private Rural Land (NZPRL) dataset. The NZPRL dataset combines information from different high-resolution digital maps from Aotearoa New Zealand. Table 3-1, on page 104, summarises the original maps I used for the NZPRL dataset. These maps are mostly in a shapefile format represented in polygons. Because each original map has different polygon sizes, I performed a sample by placing a raster over every map. A raster is an artificially imposed grid of a specific size; the one used is $500 \mathrm{~m}$ by $500 \mathrm{~m}\left(25\right.$ hectares). ${ }^{48}$

\footnotetext{
${ }^{48}$ Some information is lost between conversions from shapefile into raster, but this procedure is necessary for econometric processes (Müller, 2005) and has been broadly used. See, for example, Carrion-Flores, Flores-Lagunes, \& Guci, 2009; Lubowski, 2002; Nelson \& Hellerstein, 1997.
} 
This methodology has been broadly used for spatial econometric analysis, because raster data is useful for its compact data storage, conceptual simplicity and wellestablished algorithms for processing and analysing (Müller, 2005). Additionally, it is a convenient way to create a dataset, where the observation unit becomes a pixel of 25 hectares. A pixel is a unit of observation with information of a specific polygon and has a unique identifier. 49

The total sample of the NZPRL dataset for estimations consists of 673,483 pixels (equivalent to about 17 million hectares), where $93.6 \%$ of the sample is general land and $6.4 \%$ is Māori freehold land. Within Māori freehold land, 83\% of the pixels have a Māori land governance structure in place (hereafter Māori freehold land with structure). Considering that I am interested in decisions on private rural land, I exclude land that is under the jurisdiction of the Department of Conservation (DOC) or is classified as Crown Land, Crown Land Reserve for Māori or Māori Reservations. I also exclude pixels in urban, non-productive (such as permanent ice and snow or mangrove) land-cover activities and the sea. ${ }^{50}$ This sample does not include pixels where values are missing for slope, land use capability (LUC) or distance to port and supermarket.

In the next section, I describe the data sources used for creating the dependent variable - rural land-cover classes - followed by the independent variables - Māori freehold land, Māori freehold land with structure, location and geophysical conditions of the land. In Table 3-2, on page 105, I present a summary statistic of the NZPRL dataset.

${ }^{49}$ For creating the NZPRL dataset, it was critical to consider three things. First, every map or layer had to have the same coordinates system. Second, I created a raster file in an ACSII data format for each variable of the shapefile. It was critical to use the same grid on every raster file, so that each pixel had a unique identifier that could be used to merge all the pixels' attributes associated with the different raster files. Using ArcGIS 10, I assigned the value of each pixel with the option 'cell centre' to choose the central point of the pixel. As a result, every ACSII file reached a total of $6,079,200$ pixels over the whole grid and the information was saved as a matrix. Third, using Stata 15 , I converted each matrix into vectors that captured the pixels' attributes and merged all the rasters to create the NZPRL dataset.

${ }^{50}$ In total 1,069,978 pixels have information on the land-cover classes, and $4.5 \%$ of the $1,069,978$ pixels have missing values. $9 \%$ of this sample is in urban and non-productive land covers. At 2012, urban covered $0.8 \%$ (9,202 pixels) and non-productive covered $7.4 \%(79,788$ pixels). Between 1997 and 2012, the increased growth rate in the urban area was $10 \%(21,025$ pixels $)$ and the increased rate in the non-productive area was $0.1 \%(2,425$ pixels $)$. 


\subsection{Dependent variables}

The dependent variable that I use for the econometric analysis is the rural land-cover classes. As introduced in Section 1, my quantitative analysis on land-cover choices is divided into land-cover shares, which refers to land allocation to certain land-cover in 2012, and land-cover transitions, which refers to changes (or conversions) among different land-cover alternatives between 1997 and 2012. I chose this time as it covers the most prolonged period available in the dataset. As discussed in the conceptual framework, land-cover transitions can be slow due to conversion costs associated with conversions.

The information about the rural land-cover classes comes from the land cover database (LCDB) version 4.1, satellite imagery of the surface of the mainland for four summer periods: 1996/97, 2001/02, 2007/08, and 2011/12.51 The LCDB has information on 33 land-cover categories, not land-uses. Consequently, it is not possible to identify the types of livestock on pasture, such as dairy or sheep and beef activities. I aggregate the land-cover categories into seven land-cover classes; these classes are based on the Land Use Rural New Zealand (LURNZ) model's concordances (Anastasiadis et al., 2013) (see Table 3-3 on page 106). ${ }^{52}$ For this research, the rural land-cover classes included are horticulture, pasture, forestry, scrub and indigenous forest.

\subsubsection{Land-cover shares in 2012}

In 2012, although pasture was the main rural land cover, $68.5 \%$ of general land was actively used for pasture compared to 33.9\% of Māori freehold land. Proportionally, forestry did not show a major difference for general land (12\%) and Māori freehold land (14.3\%). 21.8\% of Māori freehold land was in scrub compared with 9\% of general land,

\footnotetext{
51 In January 2020, Manaaki Whenua Landcare Research released the land cover database (LCDB) version 5. This version includes corrections to all time steps 1996/97, 2001/02, 2007/08, 2011/12 and 2018/19 for both the New Zealand mainland and Chatham Islands (Creative Commons Attribution 4.0 International, 2020).

52 The LURNZ model was created by Motu to simulate land-use transitions in New Zealand. This model aims to investigate the potential implications of land-use decisions as a result of environmental policies. For further details see Motu Economic and Public Policy Research Trust
} (2020). 
while $29 \%$ of Māori freehold land was in indigenous forest, compared with $7.6 \%$ of general land (see Figure 3-1, below).

Figure 3-1 Land-cover shares in 2012 by land status

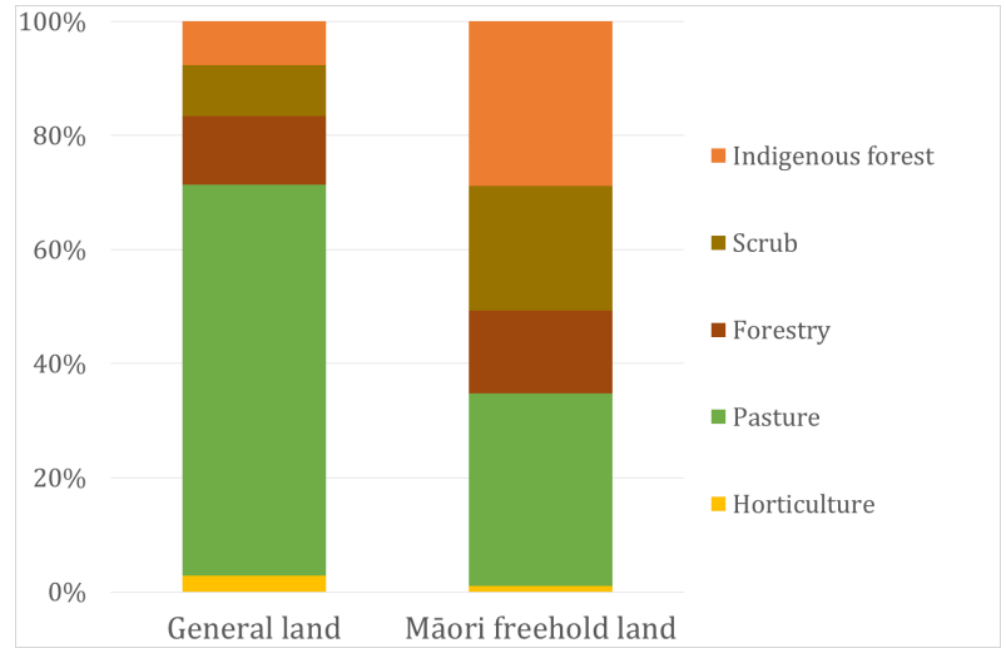

Figure 3-2 (below) shows Maori freehold land disaggregated by land with and without structure. In 2012, 16.6\% of Māori freehold land with structure was in forestry, while only $4.6 \%$ of Māori freehold land without structure was in forestry. Scrub also showed an important difference between Māori freehold land with structure (20.5\%) and without structure (28.1\%).

Figure 3-2 Land-cover shares in 2012 by Māori freehold land with or without structure

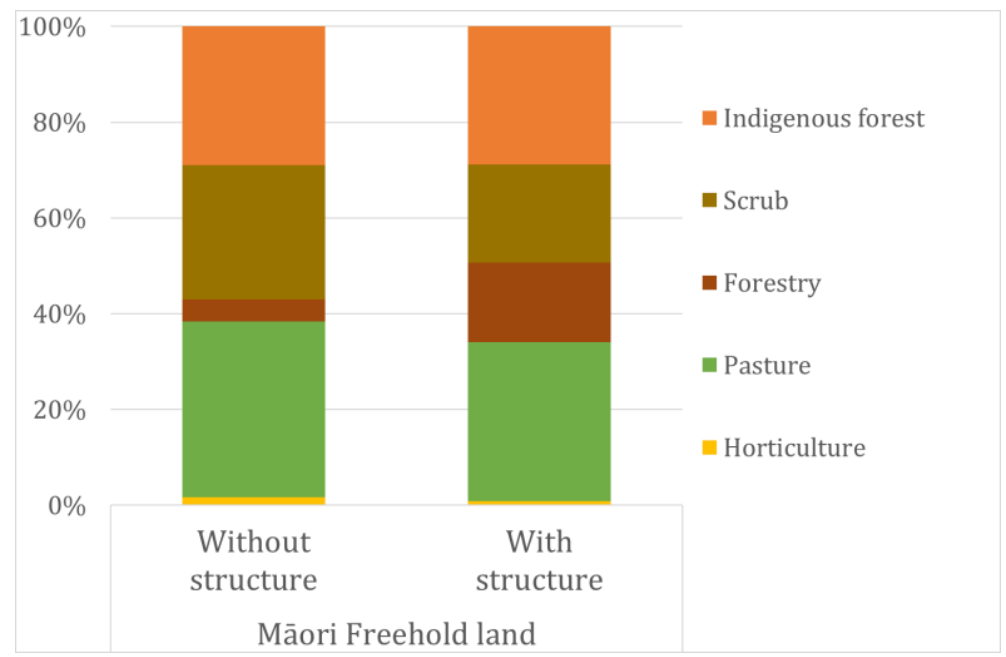

\subsubsection{Land-cover transitions between 1997-2012}

The disposition of pixels across different land covers over time (1997 and 2012) of general land and Māori freehold land, and within Māori freehold land divided by land 
with structure and without structure are illustrated in Table 3-4 on page 107. The diagonal elements of Table 3-4 show that pixels tend to largely remain in their previous land-cover.

For those pixels starting in pasture in 1997, 2.2\% of pixels of general land and $2.4 \%$ of pixels of Māori freehold land show an active transition into forestry, while $0.4 \%$ of pixels of general land and 2.2\% of pixels of Māori freehold land have a passive transition into scrub. Within Māori freehold land, an active transition into forestry is proportionally higher in pixels with a Māori land governance structure in place $(2.6 \%)$ compared with pixels without structure $(1.7 \%)$, while a passive transition into scrub seems to be lower in pixels with a governance structure $(2.1 \%)$ relative to those without structure $(2.6 \%)$.

For pixels starting in forestry in 1997, the main transition observed is an active transition into pasture, with $4.6 \%$ of pixels of general land and $1.4 \%$ of pixels of Māori freehold land. Comparing this transition within Māori freehold the proportions are moderately large, with $1.3 \%$ of pixels with a governance structure relative to $3.5 \%$ of pixels without a governance structure. However, these proportions only represent a few pixels.

For those pixels starting in scrub in $1997,4 \%$ of pixels of general land and $1.3 \%$ of pixels of Māori freehold land show an active transition into pasture, while 3.4\% of pixels of general land and 1.5\% of pixels of Māori freehold land make an active transition into forestry. Within Māori freehold land, an active transition into pasture is slightly higher in pixels with a Māori land governance structure in place (1.4\%) compared with pixels without structure (1.3\%), and an active transition into forestry is proportionally higher in pixels with a governance structure $(1.7 \%)$ relative to those without structure $(0.8 \%)$.

\subsection{Independent variables}

\subsubsection{Māori freehold land and Māori freehold land with structure}

My main independent variables of interest are two dichotomous variables to define whether a pixel is Māori freehold land and, within Māori freehold land, whether a pixel has a Māori land governance structure in place. I use information from two maps: the Māori land spatial dataset and the Department of Conservation (DOC) public conservation areas. In what follows, I first describe the maps used and then the procedure to create the two dichotomous variables. 
The first map I use is the Mãori land spatial dataset, which has cross-sectional information for 2017 based on a combination of public permanent records of the Māori Land Court and static data from the Māori Land Information System. ${ }^{53}$ This dataset includes information on the status of the land as defined by the TTWM: Māori freehold land, general land owned by Māori, Crown land, Crown land reserved for Māori and Māori Customary land. According to the records of the Māori Land Court, this dataset also includes information on management structures, such as Ahu Whenua trusts, Māori incorporations, Māori reservation, whenua tōpū trusts, putea trusts and 'other' (Ministry of Justice \& Ministry for Primary Industries, 2017).54

The second map I use is the Department of Conservation (DOC) public conservation areas, which is a cross-sectional map for 2017. It is a spatial map representation of DOC's management land units defined by various Parliament Acts and legislation. This map provides information on conservation areas, marginal strips and national parks.

As I am interested in the land-cover decisions on private rural land, I define the pixels of general land by merging these two maps. In other words, I assume that general land are pixels with no information about 1) being Māori freehold land, 2) being under management of DOC, and 3) being general land owned by Māori, Crown land, Crown land reserved for Māori, Māori Customary land, Māori reservation, Whenua Tōpū trusts and 'other'. 55

53 This dataset does not provide information on land returned or involved in any Treaty of Waitangi Settlement process, unless the settlement legislation required the land to become Māori freehold land or Māori reservation (Ministry of Justice \& Ministry for Primary Industries, 2017). 54 In the Māori land spatial dataset factsheet published by Ministry of Justice \& Ministry for Primary Industries (2017), the management structure recorded by the Māori Land Court as 'Māori reservation' refers to "Māori reservations, Urupā and Marae established and/or subject to part 17 of Te Ture Whenua Māori Act 1993 (including any reservation created under any other enactment, Crown grant, proclamation, Gazette Notice or other instrument of title)" (p.6). Additionally, the management structure called 'other' refers to "non-Māori Land Court created entities or structures which contain Māori land and/or general land owned by Māori and that by virtue of section 236 are subject to sections 237 to 245 of Te Ture Whenua Māori Act 1993" (p. 6).

55 After deleting missing values and merging both datasets, 324,768 pixels were classified either as managed by DOC or as Crown land, while 628 pixels were classified as Māori customary land or general land owned by Māori. Additionally, 3,979 pixels were either Māori reservation or managed by another entity or a Whenua Tōpū trust. 
In summary, the dichotomous variable Māori freehold land is equal to one for Māori freehold land and zero for general land. The other dichotomous variable of interest is Māori freehold land with structure. This one is equal to one for those pixels of Māori freehold land with a Māori land governance structure (Ahu Whenua trusts or Māori incorporations) in place and zero for those pixels of Māori freehold without a governance and all the pixels classified as general land.

In my dataset $6.4 \%$ of the 16.8 million hectares used in private rural activities are classified as Māori freehold land, where 83\% of this land is administered by a Māori land governance structure (with structure) (see Table 3-2 on page 105).56 Based on information from the Māori land spatial dataset, the average size of blocks with structure is 114 hectares, while the average size of blocks without structure is 14 hectares. ${ }^{57}$ On average a block of Māori freehold land with structure has 172 landowners, while a block without structure has on average 41 landowners. ${ }^{58}$

\subsubsection{Location and geophysical conditions}

Location and geophysical conditions of the land determine its productivity and its suitability for certain land uses, and influence the production costs likely to be associated with each land use.

56 This information differs by sources. The Māori Land Court (2019) published that in June 2019, $82 \%$ of Māori freehold land was vested by any type of structure, including Ahu Whenua trusts, Whenua Tōpū trusts, Pūtea trusts, Māori incorporations and non-Māori Land Court created structures or organisations. Unfortunately, this information cannot be separated into Māori incorporations and Ahu Whenua trusts. On the other hand, Kingi (2009) calculated that about $65 \%$ of all Māori freehold land was administered by a Māori land governance structure, where the largest concentration of Māori incorporations was in Tairāwhiti (the East Coast of the North Island) and the largest proportion of Ahu Whenua trusts was in Tai Tokerau (the Bay of Plenty). ${ }^{57}$ For general context, according to the 2012 Agricultural Production Census, the average farm size for Beef Cattle Farming (specialised) is 111 hectares, Dairy Cattle Farming is 199 hectares, Sheep Farming (specialised) is 531 hectares and Sheep-Beef Cattle Farming is 715 hectares (Land Information New Zealand, 2012).

58 I did not include the size of the land block and the number of landowners as independent variables because I do not have this information for general land and these variables might be correlated with having a Māori land governance structure in place. 


\section{Distance to supermarket and distance to port}

To capture location, I use two distance measurements created by Timar (2011) distance to the nearest town and distance to the nearest commercial port. Distance to town also intends to capture the cost of access to production factors such as labour, which are expected to influence a major proportion of the more labour-intensive landuse alternatives. Distance to ports intends to measure the cost of bringing the commodity to the market, as most of the agricultural products from Aotearoa New Zealand are exported. Table 3-2, on page 105, shows that on average Māori freehold land is further away from ports and supermarkets than general land. Within Māori freehold land, it is interesting that on average the pixels of Māori freehold land with structure are further away than those without structure.

\section{North Island}

Another location variable I include is a North Island dummy. ${ }^{59}$ In terms of regeneration, it is more likely that land on the North Island regenerates into scrub and indigenous forest by itself than land on the South Island. This is due to soil characteristics, the climate and natural seed sources which are more common in the North Island. Furthermore, the North Island has higher overall growth rates of Pinus Radiata forest than the South Island because of adequate rainfall and higher mean temperature in most regions (Dymond, Ausseil, Ekanayake, \& Kirschbaum, 2012). Most of the Māori freehold land is located in the North Island, predominantly in the Aotea, Waiariki and Tairāwhiti Māori Land Court Districts, as shown in Table 3-5, Figure 3-4 and Figure 3-5, all at the end of this chapter.

\section{Slope and land use capability (LUC)}

For capturing geophysical conditions, I use slope and LUC classes. Slope information comes from the Land Environments of New Zealand (LENZ) dataset (Landcare Research, 2004) and measures the slope of the land (in degrees). The LUC map measures the land's capacity for long-term sustained production; the level of versatility of the land decreases from 1 to 8 LUC classes, with 1 being land more suitable for multiple land uses

\footnotetext{
${ }^{59} \mathrm{An}$ interesting variable to include, or potentially replace the North Island dummy, could be the latitude coordinates of the grid to control for unobserved spatial variation.
} 
and 8 being land that is best managed for conservation land (Landcare Research \& Ministry of Agriculture and Forestry, 2002; Lynn et al., 2009).

As described in Chapter One, the most fertile and suitable land for agricultural activities was bought or confiscated during the 1800s (Harmsworth, et al., 2010; Kingi, 2008a). Consequently, Māori freehold land is of poorer quality than general land. As reported in Table 3-2, on page 105, and shown in Figure 3-3 and Figure 3-4 (below) less than $20 \%$ of Māori freehold land is classified in LUC classes 1 to 4 and is on average steeper than general land. Interestingly, the pixels of Māori freehold land with structure are on average steeper than those without a structure in place, and proportionally less than $20 \%$ are classified as LUC classes 1 to 4.60

Figure 3-3 LUC classes by land status

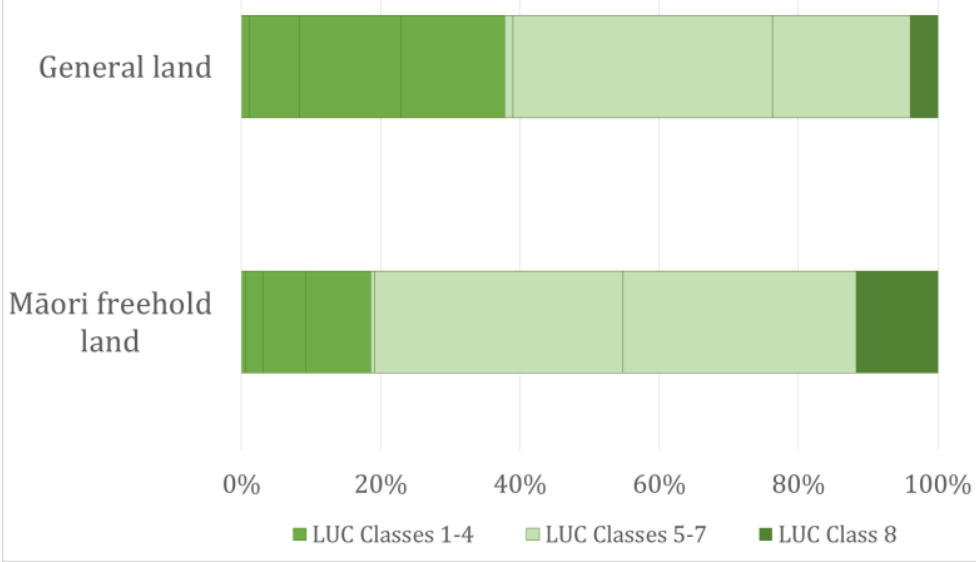

${ }^{60}$ Māori freehold land without structure seems to be of higher quality than land with a structure. It might be that lower quality land might require a Māori land governance structure before it can be used effectively because it would require more investment. It is also possible that lower quality land has more complex ownership structures, such as more absentee owners, and thus requires a governance structure for any investment decisions. This would suggest that the direction of endogeneity bias when a governance structure is used to causally predict capital intensive uses would be negative. All else equal, a governance structure might help decision making and movement into higher valued uses but the existence of the structure may be correlated with unobservably lower land quality which would make higher valued uses less likely thus biasing the size of the coefficient down. It might be interesting to interact LUC classes 1 to 4 variable with Māori land governance structure. 
Figure 3-4 LUC classes by Māori freehold land with or without structure

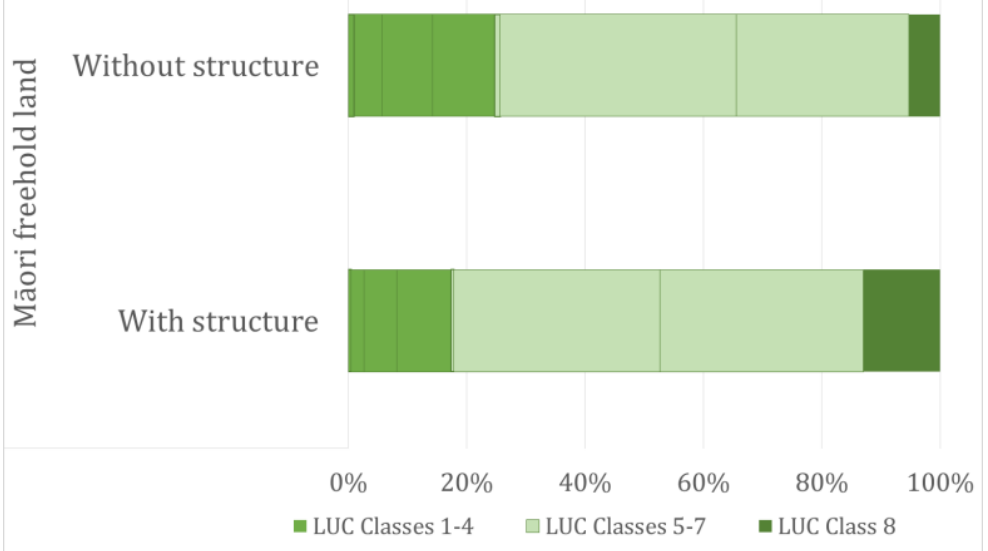

\section{Maximum likelihood approach: analytical framework}

In this section, I introduce the econometric strategies that I follow to develop my analysis on land-cover choices, using the NZPRL dataset. As presented in Section 1, I separate these choices into land-cover shares and land-cover transitions. First, as an attempt to replicate the work developed by Timar $(2011 ; 2016)$, I use a multinomial logit model to look at the land-cover shares in 2012 and test whether Māori freehold land is less likely to be used for capital intensive activities (such as horticulture, pasture, forestry), relative to general land. Then, following the same econometric approach, I concentrate my analysis on Māori freehold land and include Māori land governance structures as an independent variable. I test whether having a structure in place is associated with land-cover shares.

Second, using logit models, I look at the land-cover transitions between 1997 and 2012 to test whether Māori freehold land was less likely to make an active transition, relative to general land. Next, comparing within Māori freehold land, I include Māori land governance structures to test whether having a structure in place influenced these transitions.

\subsection{Land-cover shares in 2012}

Based on the decision rule presented in Equation [3-7], landowners select the landcover $a$ that solves: 


$$
\max _{a}\left(U_{i a}\right)=\max _{a}\left(\frac{\pi_{i a}}{r}+\frac{\omega_{i a}}{\delta}\right)
$$

Following Lubowski (2002), I use a general random utility expression, so landowners' utility can be written as a function of observed and unobserved variables: $U_{i a}=\beta^{\prime} x_{i}+$ $\varepsilon_{i a}$, where $x_{i}$ is a vector of observed variables, $\beta$ are coefficients and $\varepsilon_{i a}$ is a random error term.

The probability that landowners allocated the land unit $i$ to the land-cover $a$ is then:

$$
\operatorname{Pr}\left(\beta^{\prime} x_{i}+\varepsilon_{i a} \geq \beta^{\prime} x_{i}+\varepsilon_{i d}\right)
$$

Assuming the error terms $(\varepsilon)$ are independent and identically distributed type I extreme value', the functional form of the probability is a multinomial logit (McFadden, 1973). ${ }^{61}$ The multinomial logit model and its choice probabilities can be expressed as:

$$
\operatorname{Prob}(y=1 \mid x)=\frac{\exp \left(\beta^{\prime} x_{i}\right)}{1+\sum_{d} \exp \left(\beta^{\prime} x_{i d}\right)}
$$

The vector of observable variables includes location and geophysical conditions of the land and two dichotomous variables to capture whether the land is Māori freehold land and if this land has a structure in place (Māori freehold land with or without structure).

A direct interpretation of the coefficient estimates in a multinomial logit is difficult as they relate to a base category, which affects choice probabilities in a non-linear manner (Greene, 2012). Thus, the calculation of the Average Marginal Effects (AME) can facilitate the interpretation of the results. For dichotomous variables, the AME (also known as odds ratios or partial effects) are a measure of association that approximates how much more likely (or less likely) it is for the outcome to occur given the value of the independent variable (McFadden, 1973; Hosmer \& Lemeshow, 2000; Greene, 2009).

\subsubsection{The independence from irrelevant alternatives assumption}

The assumption of Independence from Irrelevant Alternatives (IIA) is inherent to logit models and their extensions such as conditional logit and multinomial logit. The IIA assumption says that the ratio of the probability of choosing between two alternatives is

\footnotetext{
${ }^{61}$ Multinomial logits are appropriate when the choice among alternatives is modelled as a function of the characteristics of the individual making the choice, rather than (or in addition to) the characteristics of the alternatives (Hoffman \& Duncan, 1988). In my analysis, I choose a multinomial logit as I am interested in the characteristics of the land, rather than the characteristics of the different land-use alternatives.
} 
independent of a third alternative in the choice set (Hausman \& McFadden, 1984). As an example, consider a decision of allocating land between dairy or sheep and beef. Commercial forestry is also on the set of alternatives. The IIA assumption says that, for each piece of land, the odds of choosing dairy over sheep and beef is not affected by commercial forestry on the set of alternatives.

The violation of this assumption leads to inconsistent coefficient estimates and biased forecasts (Train, 2009). ${ }^{62}$ Coming back to my example, commercial forestry would draw more land from sheep and beef than from dairy; hence, the probability of allocating land to dairy relative to sheep and beef would change, violating the IIA assumption. In the context of my analysis, the IIA assumption requires that land-cover alternatives are not similar among each other and therefore these are not substitutable. Due to data restrictions, I only observe pasture as a land-cover and I cannot differentiate land uses such as dairy or sheep and beef. Therefore, I do not expect that IIA represents a major issue for my analysis.

Although the IIA assumption can represent a theoretical issue, in the context of land cover modelling its implications are un clear. ${ }^{63}$ To further relax the IIA assumption, different discrete choice models have been used in the literature about drivers of landcover choices, for example nested logit, multinomial probit and random parameters logit. ${ }^{64}$ Despite the potential drawback the IIA assumption can represent for multinomial

62 Several attempts have been proposed to test the IIA assumption for multinomial logit models, the most widely known are proposed by Hausman \& McFadden (1984) and Small \& Hsiao (1985). ${ }^{63}$ For example, Nelson et al. (2004) use three different estimating techniques and compare the prediction accuracy of a multinomial probit, a nested logit and a Random parameters logit (RPL), concluding that the overall predictive power is about the same for all three models. They also concluded that both the multinomial model and the nested logit model have the highest probability, while the RPL is always the lowest. Lubowski, Plantinga, and Stavins (2008) used a nested logit specification after testing that a non-nested logit model violates the hypothesis of IIA; they found that the nested specification is not critical for their overall findings, as both specifications yield qualitatively similar results.

${ }^{64}$ In a nested logit, it is assumed that choices can be grouped into categories. Within a category the IIA assumption holds, but faces issues of heteroscedasticity (Lubowski, 2002). A multinomial probit model requires normally distributed errors and can be computationally intensive for more than four choices (Chakir \& Parent, 2009; Hausman \& McFadden, 1984). The RPL approximates any set of choice probabilities consistently with a random utility model and it requires simulation 
logit models, these have been widely applied for modelling decisions on land utilisation in different parts of the world. 65

\subsection{Land-cover transitions 1997-2012}

For landowners with a land unit $i$ starting in land-cover $d \in\{\mathrm{j}, \mathrm{k}, \mathrm{l}\}$, the probability of switching to a land-cover alternative $a \in\{\mathrm{j}, \mathrm{k}, \mathrm{l}\}$ is given by $\mathrm{P}_{i d a}$. Following the decision rule from Equation [3-7].

$$
\mathrm{P}_{\mathrm{ida}}=\operatorname{prob}\left(\left[\frac{\pi_{\mathrm{ida}}}{\mathrm{r}}+\frac{\omega_{\mathrm{ida}}}{\delta}\right]-\mathrm{C}_{\mathrm{da}}>\left[\frac{\pi_{\mathrm{id}}}{\mathrm{r}}+\frac{\omega_{\mathrm{id}}}{\delta}\right]\right)
$$

Once again, I use a general random utility expression, so the landowners' utility can be written as a function of observed and unobserved variables: $U_{i a d}=\beta^{\prime} x_{i}+\varepsilon_{i d a}$. I estimate $\mathrm{P}_{i d a}$ using a logit estimation 66 , in which case:

$$
\operatorname{Prob}(y=1 \mid x)=\frac{\exp \left(\beta^{\prime} x_{i}\right)}{1+\exp \left(\beta^{\prime} x_{i}\right)}=\Lambda\left(\beta^{\prime} x_{i}\right)
$$

In Equation [3-12], $\Lambda(\cdot)$ indicates the logistic cumulative distribution function and $x_{i}$, $\beta$ the coefficient estimates (Train, 2009). Similar to multinomial logits, the interpretation of the coefficient estimates for logit models is not straightforward, so I present the results in terms of the AME.

The dependent variable for each model estimated is a dummy variable that takes the value one to indicate a specific land cover in 2012. As in the land-cover shares model, the vector of observable variables (or independent variables) includes location, geophysical conditions of the land and the two dichotomous variables of interest - Māori freehold land and Māori land governance structures.

methods to estimate the unknown distribution created by the different random components; its estimation is computationally intensive for large samples (Lubowski, 2002; McFadden \& Train, 2000; Polyakov \& Zhang, 2008).

${ }^{65}$ For example: Carrion-Flores et al., 2009; Chomitz \& Gray, 1996; Heilmayr, 2015; Li, Wu, \& Deng, 2013; Lubowski et al., 2008; and Nelson et al., 2001, 2004.

66 Multinomial logit estimates multiple equations and requires a larger sample size than a binary logistic regression. As shown in Table 3-3, the sample distribution of Māori freehold land with and without structure is uneven in comparison with the proportion of pixels of general land. This represents a difficulty for using a multinomial logit. 


\subsection{Econometric issues}

In this subsection, I consider two potential econometric issues that might influence my econometric results. One is spatial effects, which may arise when using a spatial discrete choice land-cover model. The second is endogeneity caused by simultaneous causality or omitted variable bias. Before moving to these specific econometric issues, let me talk about an 'empirical conundrum' that can arise when making inference about odds ratios rather than coefficient estimates.

The econometric technique does not guarantee that both the coefficient estimates and the related odds ratios are statistically significant (or insignificant) (Greene, 2009; Dowd, Greene, \& Norton, 2014). William Greene (2009) states that:

in the event of a conflict, one is left with the uncomfortable problem of simultaneously rejecting and not rejecting the hypothesis that a variable should appear in the model. Opinions differ on how to proceed. Arguably, the inference should be about $\theta \mathrm{k}$ [coefficient estimates], not $\delta \mathrm{k}$ [odds ratios], since in the latter case, one is testing a hypothesis about a function of all the coefficients, not just the one of interest (p. 487).

Thus, in Section 4, I present the estimation results. Statistical significance is calculating with robust standard errors, for both the coefficient estimates and the related odds ratios (or AME). ${ }^{67}$

In the following subsection, I discuss two potential econometric issues that might influence my econometric results.

\footnotetext{
${ }^{67} \mathrm{An}$ additional consideration that can arise in my analysis is the decision as to whether I should adjust standard errors for clustering. Abadie, Athey, Imbens, and Wooldridge (2017) argue that clustering is a 'design problem' due to 'sampling design' or 'experimental design' issues. Perhaps, a sampling design issue could motivate the need to adjust standard errors for clustering; therefore, the results may not be generalised to the broader land in New Zealand under the land status of Māori freehold land (note that a similar situation can occur for general land). Although this further analysis is necessary to gain a better understanding of the need for clustering because of the sampling design, this work is beyond the scope of my current analysis.
} 


\subsubsection{Spatial effects}

Spatial econometrics analysis may deal with spatial effects divided into spatial heterogeneity and spatial autocorrelation. Spatial heterogeneity is associated with uneven distribution of certain characteristics within a location (Anselin, 1988) that lead to measurement errors. Spatial autocorrelation is associated with the first law of geography: "everything is related to everything else, but near things are more related than distant things" (Tobler, 1970, p. 236). In the context of my analysis, a potential source of spatial autocorrelation stems from ownership patterns and preferences for certain land-cover, which can be motivated by cultural values or a sense of identity. By data construction, several pixels can capture information for the same land block, sharing location features (Anselin, 1988; Hsieh, Irwin, \& Forster, 2000). ${ }^{68}$

Ignoring spatial effects can lead to inaccurate measures of statistical significance or inefficient coefficient estimates, because of possible heteroscedastic error or biased estimates (Anselin, 2001; Anselin, Florax, \& Rey, 2004). Spatial heterogeneity can be addressed by standard econometric methods, commonly associated with time series approaches. In the literature, spatial autocorrelation has been commonly addressed using ad hoc methods such as re-estimating the econometric specification by using different no-nearest neighbours sub-samples (spatial sub-sampling) (Robertson, Nelson, \& De Pinto, 2009).

Spatial sub-sampling aims to use observations located sufficiently apart from one another, under the rationale that the spatial autocorrelation decays if the distance increases. This technique consists of re-estimating the models on a sub-sample drawn to maximise the distance between observations. It has been widely employed in the literature (see for example: Carrion-Flores \& Irwin, 2004; Lubowski, Plantinga, \& Stavins, 2008; Nelson \& Hellerstein, 1997; Timar, 2011).

\footnotetext{
68 The most popular test for spatial autocorrelation in discrete choice models is one based on Moran's I (Lesage, 2000; McMillen, 1992). I attempted to calculate Moran's I, using the NZPRL dataset. However, consistent with other studies, this calculation is computationally demanding as the number of observations in the sample increases (Beron \& Vijverberg, 2004).
} 
To test the robustness of my results to potential spatial autocorrelation, I calculate two subsamples. ${ }^{69}$ The first subsample (hereafter, SG3) consists of a systematic spatial sample, eliminating the nearest neighbours from the sample. More specifically, I draw the spatial sample SG3 by selecting every third pixel in the X-and Y-direction (Müller, 2005). The second subsample (hereafter, RS) consists of a random spatial sample drawn by selecting the same sample size of SG3. For example, after eliminating the nearest neighbours SG3 results in 74,900 observations; then I use the same number of observations to randomly select a subsample for RS.

\subsubsection{Endogeneity}

Endogeneity leads to biased estimates when the dependent variable is determined simultaneously with an independent variable or when the error term and an independent variable are correlated (Greene, 2012). I have identified two potential sources of endogeneity that could affect my analysis. The first of these is simultaneity between land-cover choices and having a Māori land governance structure in place. The second is omitted variable bias because of unobservable characteristics of landowners that might influence both the land-cover choices and the establishment of a Māori land governance structure.

First, simultaneity can be associated with unobservable land characteristics that might influence decisions on land utilisation and the establishment of a Māori land governance structure simultaneously. In Chapter Two, I explore the nature of the decision-making process associated with choosing to go into pine forest and discuss a joint venture between a forestry company and a group of Māori landowners. In this specific example, the opportunity of using the land for forestry activities motivates the establishment of a structure to facilitate decisions.

Second, omitted variable bias can be associated with landowners' ability to cooperate or make a decision, such as establishing a Māori land governance structure or using their land for commercial purposes. This bias can also be associated with specific details in the history of the land block that have influenced its administration and management. For example, as presented in Chapter One, before the governance structure was

${ }^{69}$ For my analysis I could not create different sub-samples by selecting different neighbours, because Māori freehold land with and without structure only represents a few observations within the whole sample (see Table 3-2 on page 105). 
established at Kerikeri Station, the land was formerly administered and developed by the Department of Māori Affairs. This case study led me to conclude that this Department influenced decisions concerning land use and the selections of governance structures.

One option to address the potential endogeneity would be to use an instrumental variable (IV) for the Māori land governance variable. Although, appealing this strategy is, it is difficult to implement because of the necessity of finding an appropriate IV that meets two requirements: to be uncorrelated with unobserved determinants of the dependent variable of interest and to be correlated with the endogenous variable (Foster, 1997).

Alternatively, a potential way to address the endogeneity issue would be to identify the year of constitution of the Māori land governance structures, but unfortunately this information is not publicly available. In a hypothetical situation where this information was available, it would be possible to know if allocation of land to certain land-cover alternative was made before the establishment of the governance structure. For estimation on land-cover transitions, I expect that exogeneity is more plausible because more 'imposed' governance structures were already established by 1993 (before the TTWM), and carrying out a land-cover transition is not a discussion that occurs simultaneously. Based on the field work documented in Chapter Two, I argue that landowners would start thinking about having a governance structure in place before actually changing the activity on the land. Or, as discussed in Chapter One, once a governance structure is established, the board members can explore potential changes.

\section{Estimation results}

In this section, I describe the results of the econometric modelling exercise, which is divided into two analyses: land-cover shares in 2012 and land-cover transitions from 1997 to 2012.

\subsection{Land-cover shares in 2012}

I used a multinomial logit model to first estimate the likelihood of Māori freehold land being used for capital intensive activities relative to general land. I assumed that the more capital-intensive activities are horticulture, pasture and forestry. In the second 
estimation, I included the dichotomous variable of Māori land governance structures to test whether having governance structures in place influences this likelihood.

As mentioned previously, it is difficult to make a direct interpretation of the coefficient estimates from a multinomial logit as they relate to the base category, scrub. ${ }^{70}$ Therefore, as mentioned in Section 3.3, I discuss the results in terms of the AME, only if their associated coefficient estimates are statistically significant.

\subsubsection{Māori freehold land}

Table 3-6, on page 109, presents the results of the AME of Māori freehold land being allocated among five land-cover shares. After controlling for location and geophysical condition of the land, the results suggest that Māori freehold land is 1.4 percentage points (pp) more likely to be in horticulture, and $0.9 \mathrm{pp}$ more likely to be in forestry, but 20.5 pp less likely to be in pasture. As mentioned before, investment in Māori freehold land can be affected by capital constraints, which can explain the result on pasture, but the result of horticulture is, in some sense, surprising. ${ }^{71}$ Historical reasons can explain the positive association of Māori freehold land with forestry (Timar, 2011) or, as discussed in Chapter Two, investment in forestry can be motivated by considerations for future generations and potential economic opportunities, given investments from (or partnership with) a third party interested in this specific activity.

Additionally, my results show that Māori freehold land is $11 \mathrm{pp}$ more likely to be in scrub and $7.2 \mathrm{pp}$ more likely to be in indigenous forest. These results can be explained by the presence of amenity values and the inherent physical characteristics of the land. However, in the case of scrub, another potential explanation is capital constraints. I discuss the land allocation into scrub in the analysis on land-cover transitions.

The effects of geophysical conditions and location of the land are mostly as I expected. A higher level of versatility of the land increases the probability of observing the land in horticulture and pasture and decreases the probability of scrub and indigenous forest. As the slope of the land and the physical limitations increase, the probability of horticulture, pasture and forestry decreases. Easy access to the land and production

\footnotetext{
${ }^{70}$ See the coefficient estimates in Table A3-1 and Table A3-2 in Appendix C.

71 Timar (2016) found that Māori freehold land is $0.63 \mathrm{pp}$ more likely to be in horticulture activities than general land. As an anecdote, I was told that horticulture for Māori could be seen as a way to care about people, because it is associated with food.
} 
factors, measured by the variables of distance to supermarket and ports, increases the probability of horticulture and reduces the probability of indigenous forest. Interestingly, there is a positive effect of the distance variables on pasture; as the distance increases, the probability of pasture increases.

My results are consistent with Timar (2011; 2016), who found that in 2012 Māori freehold land was more likely to be in land uses such as horticulture, forestry and scrub, and less likely to be in dairy and sheep and beef activities. However, the magnitude of the average of predicted changes in the probabilities differs. This difference can be explained by the datasets we each use. I use the most recent information available on Māori freehold land and land managed by DOC. The other significant difference is that I only have information about land cover, while he used information on land use for dairy and sheep and beef. ${ }^{2}$

\subsubsection{Māori freehold land with structure}

Table 3-7, on page 110, provides the results of including Māori land governance structures as an independent variable. Given the way that I define the Māori land governance structure as a dichotomous variable, the AME associated with the variable Māori freehold land with structure may be read as a comparison with Māori freehold land without structure. On the other hand, the AME associated to Māori freehold land may be read as a comparison between general land and Māori freehold land without structure.

Relative to Māori freehold land without structure, the results suggest that, on average, Māori freehold land with structure is less likely to be in pasture (-11.2 pp) and is more likely to be in forestry (19.5 pp). It may be that low-intensity beef and sheep activities are the cause of the negative association between governance structure and pasture, as discussed in Chapter Two. As previously discussed, the land allocation into forestry can be explained by an opportunity to access capital in the long term. In both cases, it is much easier to discuss these land allocations in terms of land-cover transitions.

\footnotetext{
72 Timar $(2011 ; 2016)$ used a land use map for 2012, but it is not comparable across time with other land-use maps. The most reliable information for analysing transitions is at the land-cover level.
} 
The results also show that Māori freehold land with structure is $4.6 \mathrm{pp}$ less likely to be in scrub and $3.6 \mathrm{pp}$ less likely to be in indigenous forest. The results for scrub seem to be aligned with the argument that a Māori land governance structure facilitates access to capital, but further interpretation is much easier in terms of land-cover transitions. The results for indigenous forest might suggest that a governance structure is less likely to administer a block of land on indigenous forest. As with the results reported in Table 3-6 on page 109, the effect of the location and geophysical characteristics of the land are as expected.

In Section 3.3.1, I discussed the issues associated with spatial autocorrelation and the most common method used in the literature. This method involves the re-estimation of the econometric specification by using spatial sub-sampling. I used two sub-samples. Each one included only $11 \%$ of the original sample. My results are robust to systematic spatial sub-sampling; see columns 2 and 3 of Table 3-6 and Table 3-7.

In summary, the analysis of land-cover shares in 2012 suggests that Māori land governance structures have a positive association with the allocation of the land into forestry. A possible explanation is that governance structures can facilitate investment in forestry, as shown in Chapter Two. However, the argument about a positive relationship between governance structure and access to capital is somewhat counterintuitive in the case of pasture. As I discuss in Chapter One, the governance structure can help to optimise activity associated with farming, but the results do not suggest a clear inference.

Land-cover shares are a long-term 'equilibrium', and an interpretation of the way this equilibrium responds to recent policies (e.g. programmes to facilitate decision-making by Māori) or cultural drivers (e.g. Māori landowners' motivation to use their land in a particular activity) is not easy because of historical drivers. Additionally, this equilibrium is a function of the entire history of the land's utilisation, not just the presence of governance structures. One way to gain more insight into the role of Māori land governance structures is to analyse land-cover transitions, which I discuss in the next section.

\subsection{Land-cover transitions 1997-2012}

Two main questions motivate this analysis: was Māori freehold land less likely than general land to make an active transition between 1997 and 2012? Did Māori land governance structures influence these transitions? By active transition, I mean a positive 
land-cover change that involved any sort of investment. Given the information of the NZPRL dataset and the pixels' distribution among the land-cover transitions (see Table 3-4 on page 107), I assume that active transitions are pasture to forestry, forestry to pasture and scrub to pasture or forestry.

To address these questions, I used logit models to estimate the likelihood of Māori freehold land (relative to general land) to make a transition across pasture, forestry and scrub. I then included 'Māori land governance structures' as an independent variable to test whether having governance structures in place influences this likelihood.

For the econometric analysis, I restricted the sample to the subset of each starting land cover in 1997 - pasture, forestry and scrub. For example, to calculate the likelihood of the transition from pasture in 1997 to forestry in 2012, I started restricting the sample to those pixels in pasture in 1997. As a result, the sample size for this estimation is 452,152 pixels. Following this, I estimated a logit model where the dependent variable is dichotomous; that is, one when pixels were in forestry in 2012. As indicated before, interpreting the coefficient estimates from logit models is not simple; therefore, I discuss the result in terms of the AME only if their associated coefficient estimates are statistically significant. ${ }^{73}$

\subsubsection{Māori freehold land}

Table 3-8, on page 111, presents the results in terms of AME for land-cover transitions across pasture, forestry and scrub, between 1997 and 2012, comparing Māori freehold land with general land.

I begin with the set of transitions from pasture in 1997. My results show that, relative to general land, on average Māori freehold land was $1.2 \mathrm{pp}$ more likely to move into scrub in 2012, but 0.4 pp less likely to move into forestry in 2012. As discussed in the conceptual framework in Section 1, capital constraints and higher conversion costs can help to explain these results. Interestingly, relative to general land, Māori freehold land was $0.8 \mathrm{pp}$ less likely to remain in pasture. Although I cannot observe the specific uses

\footnotetext{
73 I use the coefficient estimates for a simulation exercise presented in Chapter Four. In this simulation, based on factual and counterfactual scenarios, I calculated changes in area (hectares) and indicative numbers for environmental implications of these changes. See the coefficient estimates in Table A3-3 and Table A3-4 in Appendix C.
} 
associated with pasture (such as dairy or sheep and beef), it has been documented that transitions into forestry or scrub are usually from less intensive sheep and beef farming. The next set of transitions is from forestry in 1997 to pasture in $2012 .{ }^{74}$ My results show that Māori freehold land was 3.1 pp less likely to make this transition than general land. This result is interesting, and seems to align with the argument about considerations for future generations and access to capital in the long-term. It can also be associated with the presence of amenity values. It would be interesting to complement the analysis with the age of the forest, to test whether this result is due to difference between the 15-year period of study and the rotation time for harvesting (for pine, around 28 years).

The last set of transitions is from scrub. My results suggest that, relative to general land, Māori freehold land was 3.9 pp more likely to remain in scrub, 2.3 pp less likely to move into pasture or $1.6 \mathrm{pp}$ less likely to move into forestry. These results are expected, given the capital constraints and decision costs Māori landowners face. These results can also suggest the presence of amenity values.

The effects of geophysical conditions and location of the land are mostly as I expected. Higher levels of versatility of the land and lower slope tend to be important factors for remaining in pasture, for instance. Regarding the variables of location, the results suggest that the further the land is from ports, the incentives to remain in pastoral activities increase and the incentives to move to forestry decrease because of the cost of transporting logs. The North Island variable is associated with positive transitions from pasture to forestry or scrub.

Overall, my results indicate that relative to general land, on average, Māori freehold land was less likely to make an active land-cover transition between 1997 and 2012. It means that Māori freehold land was $0.4 \mathrm{pp}$ less likely to move from pasture into forestry, 3.1 less likely to move from forestry into pasture and $2.3 \mathrm{pp}$ less likely to move from scrub into pasture. As discussed in the conceptual framework in Section 1, capital constraints or high conversion costs, which may capture financial or decision costs, can

\footnotetext{
74 The sample size is 72,729 pixels for these estimations, which is notably smaller than the sample size for the transitions from pasture. However, it is still a large sample size. As shown in Table 3-4, on page 104, only 275 pixels transitioned from forestry to scrub, from which just 10 pixels are Māori freehold land, so I do not include the transition from forestry to scrub in my analysis.
} 
explain these results. My results are similar to those of Dorner and Hyslop (2014), even though we compare different periods and use a different econometric strategy.

\subsubsection{Māori freehold land with structure}

In the second estimation, I explore the relationship between land-cover transition and Māori land governance structures. Table 3-9, on page 113, presents the results in terms of the AME. Note that the AME of Māori freehold land with structure may be read as more (or less) likely to transition than Māori freehold land without structure.

Consistent with my hypothesis, the results show that on average Māori freehold land with structure was $0.7 \mathrm{pp}$ more likely to change from pasture in 1997 to forestry in 2012, but 0.2 pp less likely to change from pasture in 1997 to scrub in 2012. Additionally, Māori freehold land with structure was 3.7 pp more likely to move from scrub in 1997 to forestry in 2012 and less likely to remain in scrub (-0.4 pp). Furthermore, having a Māori land governance structure in place is positively associated with remaining in forest (2.4 pp).

Location and geophysical characteristics, in terms of higher transport costs, access to supermarket and quality of the land appear to play an important role in reducing deforestation, for instance.

Overall, my results indicate that Māori land governance structures are associated with transitions away from pasture into forestry, but not into scrub. A transition into forestry involves conversion costs (such as financial and decision costs) that a Māori land governance structure can help to address. These results suggest that Māori land governance structures facilitate active transitions, such as allocation of land into forestry, which can be motivated by an opportunity to access capital in the long term (as discussed in Chapter Two).

\section{Summary and conclusions}

In this chapter, I quantitively estimate the relationship between Māori land governance structures and land-cover decisions. I separate these choices into land-cover shares in 2012 and land-cover transitions between 1997 and 2012.

Consistent with other studies, I found that after controlling by location and geophysical characteristics of the land, on average Māori freehold land was less likely to be pasture than general land. Furthermore, my results suggest that, in 2012 and relative 
to general land, on average Māori freehold land was more likely to be in horticulture, forestry, scrub and indigenous forest. These findings suggest that Māori freehold land is more likely to be used in activities other than pasture, but there is insufficient evidence to conclude that Māori freehold land is less likely to be used in capital intensive activities. Within Māori freehold land, the results suggest that Māori governance structures are positively associated with forestry, but negatively with scrub or indigenous forest.

As discussed in the conceptual framework, land-cover transitions can be slow due to conversion costs. The NZPRL dataset shows that the most common conversions are among pasture, forestry and scrub.

Overall, my results indicate that on average Māori freehold land is less likely to make an active land-cover transition, relative to general land. I found, for example, that Māori freehold land is on average more likely to transition from pasture towards scrub (but less likely to move into forestry), relative to general land. However, having a Māori land governance structure in place can change this tendency. Māori land governance structures improve opportunities to access to capital and facilitate decisions driven by amenity values.

These findings motivate a question: what would be the implications if all Māori freehold land had a governance structure in place? I contend that Māori land governance structures can assist in reducing some of the conversion costs intrinsic to land-use conversions. This motivates the analysis discussed in Chapter Four.

\subsection{Directions for future research}

This chapter reflects an effort to quantitatively explore the relationship between Māori land governance structures on land-cover decisions in Māori freehold land. Future research could build on these findings by including more socio-economic information in the analysis. Some ideas for future research are outlined below.

(1) Determinants or motivations for having a Māori land governance structure in place require further analysis. The data I used for my analysis is limited at the pixel level and does not include information about the socio-economic characteristics of landowners. Perhaps, the size of the land and the number of landowners are positively correlated with the need to have a structure in place. I have also discussed some potential sources of endogeneity that might influence my econometric analysis. Further research could involve the identification of an IV to test and correct for endogeneity. 
(2) Based on my experiences documented in Chapter One and Chapter Two, I observed in-the-field interactions between landowners and farm managers that could lead to spill-over effects that may influence adoption of certain land-management practices or improvements on governance capability. Exploring these effects might require other sources of information than the one I have used for my study.

(3) It would be interesting to extend the analysis to a comparison between general land and Māori freehold land with structure. The results might lead to potential similarities (or differences) in land-cover choices. For making this comparison, it would be necessary to consider the distribution of the sample, as the first group is larger than the second.

(4) A new version of the LCDB was released in January 2020. This version includes land cover information for 2018/19. This new version provides a longer period for extending the analysis on land-cover transitions, which could be included in future research. 


\section{Figures and tables}

Figure 3-4 Māori freehold land by Māori Land Court Districts

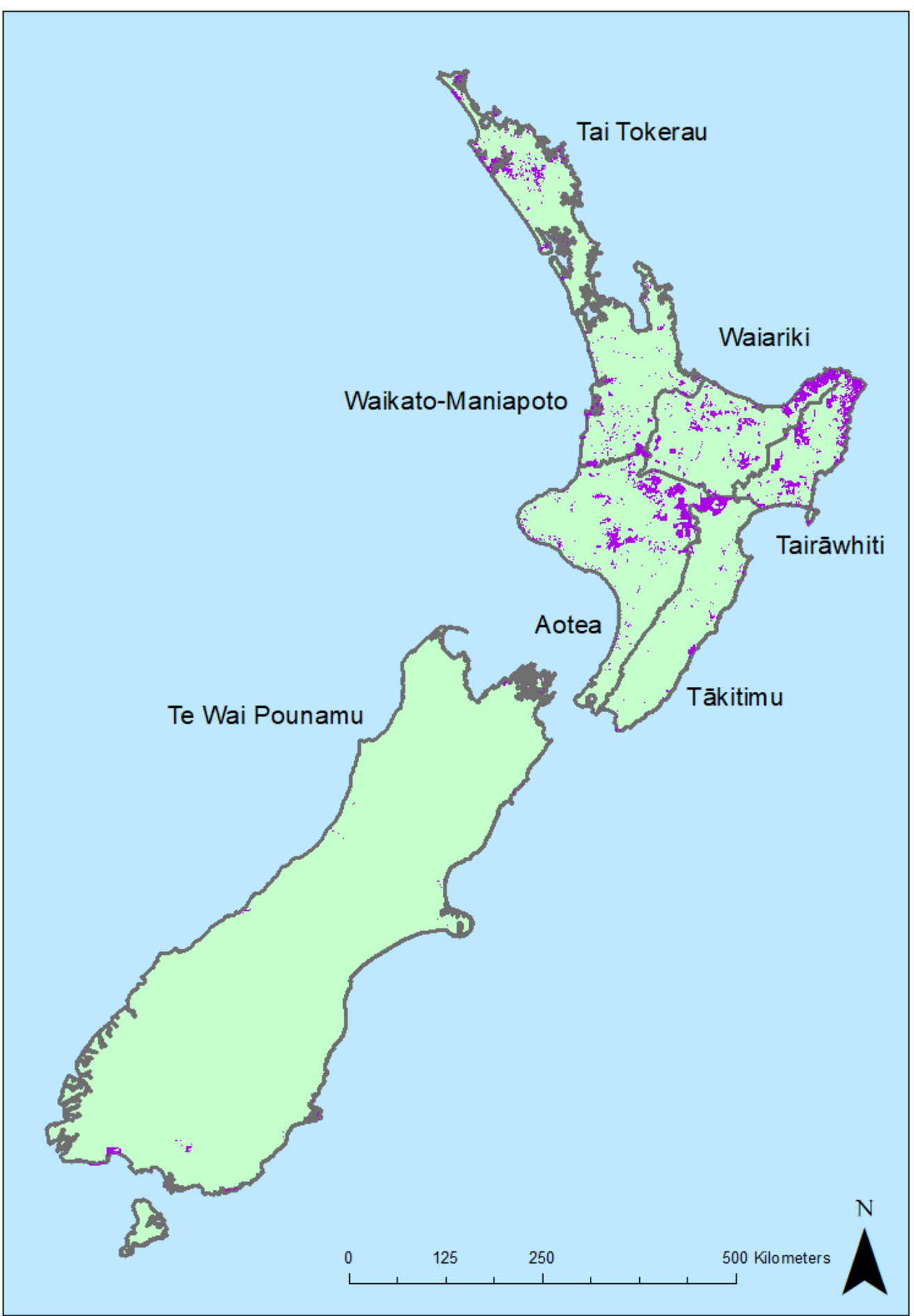


Figure 3-5 Māori freehold land with and without structure by Māori Land Court Districts

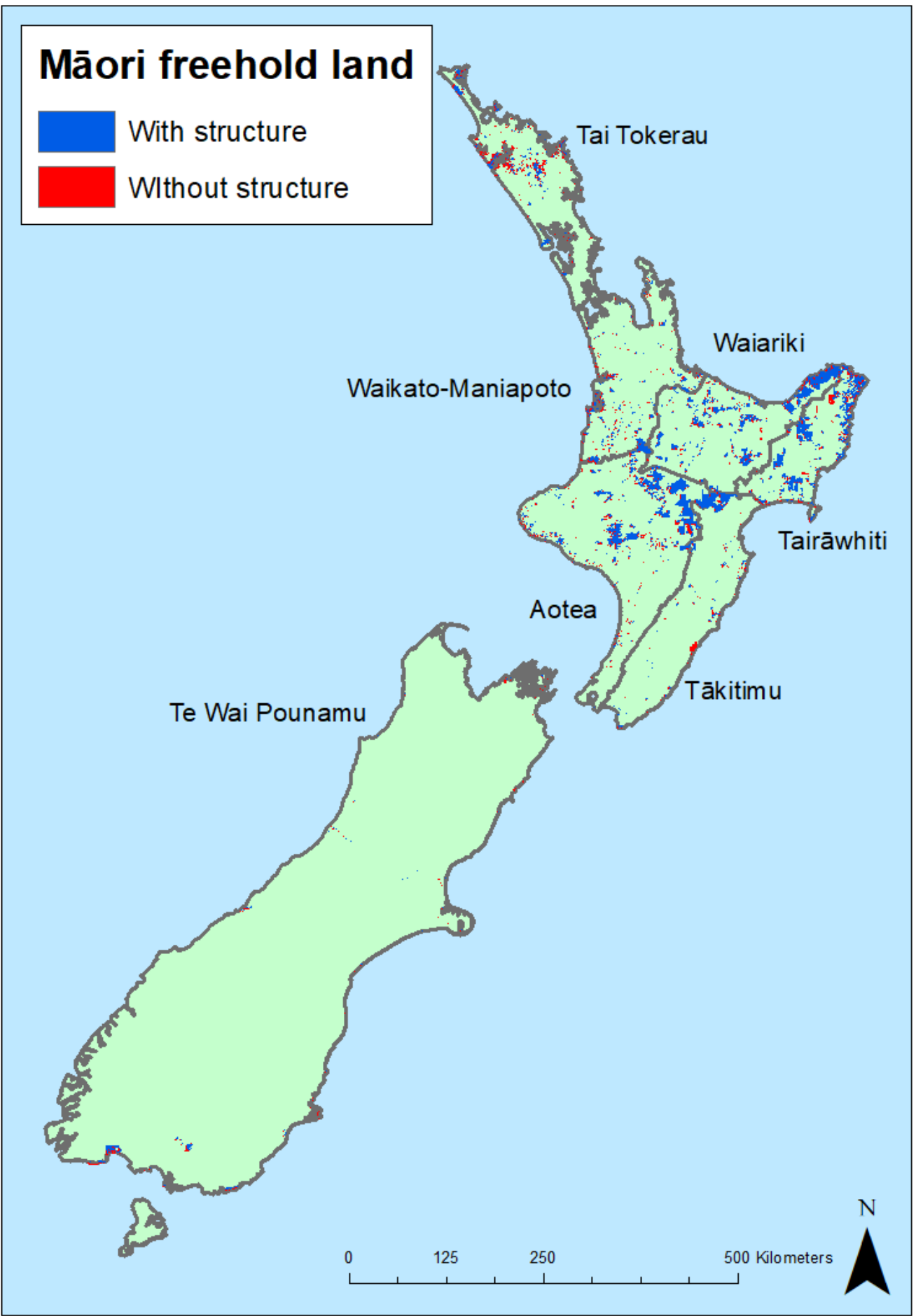

Figure A3-1 and Figure A3-2, in Appendix C, present the previous map in the North Island and the South Island, respectively. 
Table 3-1 Data sources for the NZPRL dataset

\begin{tabular}{|c|c|c|c|}
\hline Variables & Type & Digital maps & $\begin{array}{l}\text { Source, license or } \\
\text { published by }\end{array}$ \\
\hline Rural land cover & Categorical & $\begin{array}{l}\text { Land cover database version } \\
4.1 \text { (LCDB } 4.1 \text { ) }\end{array}$ & $\begin{array}{l}\text { Landcare Research - } \\
\text { Manaaki Whenua (Landcare } \\
\text { Research, 2015) }\end{array}$ \\
\hline \multirow[t]{2}{*}{$\begin{array}{l}\text { Māori freehold } \\
\text { land }\end{array}$} & Dichotomous & Māori land spatial dataset & $\begin{array}{l}\text { Ministry of Justice and } \\
\text { Ministry for Primary } \\
\text { Industries (on behalf of the } \\
\text { Māori Land Court) (Ministry } \\
\text { of Justice \& Ministry for } \\
\text { Primary Industries, 2017) }\end{array}$ \\
\hline & & $\begin{array}{l}\text { Department of Conservation } \\
\text { (DOC) public conservation } \\
\text { areas. }\end{array}$ & $\begin{array}{l}\text { Creative commons } \\
\text { attribution } 3.0 \text { New Zealand } \\
(2017)\end{array}$ \\
\hline $\begin{array}{l}\text { Māori freehold } \\
\text { with structure }\end{array}$ & Dichotomous & Māori land spatial dataset & $\begin{array}{l}\text { Ministry of Justice and } \\
\text { Ministry for Primary } \\
\text { Industries (on behalf of the } \\
\text { Māori Land Court) (Ministry } \\
\text { of Justice \& Ministry for } \\
\text { Primary Industries, 2017) }\end{array}$ \\
\hline $\begin{array}{l}\text { Land use } \\
\text { capability (LUC) }\end{array}$ & Categorical & Land use capability (LUC) & $\begin{array}{l}\text { Landcare Research - } \\
\text { Manaaki Whenua (Landcare } \\
\text { Research \& Ministry of } \\
\text { Agriculture and Forestry, } \\
\text { 2002). }\end{array}$ \\
\hline Slope of the land & Categorical & $\begin{array}{l}\text { Land Environments of New } \\
\text { Zealand (LENZ) }\end{array}$ & $\begin{array}{l}\text { Landcare Research - } \\
\text { Manaaki Whenua (Landcare } \\
\text { Research, 2004). }\end{array}$ \\
\hline $\begin{array}{l}\text { Distance to } \\
\text { supermarkets } \\
\text { Distance to ports }\end{array}$ & Continuous & & $\begin{array}{l}\text { Motu Economic and Public } \\
\text { Policy Research. Created by } \\
\text { Timar (2011) }\end{array}$ \\
\hline
\end{tabular}


Table 3-2 Summary statistics for the NZPRL dataset

\begin{tabular}{|c|c|c|c|c|c|}
\hline & \multirow{2}{*}{$\begin{array}{c}\text { Total } \\
\text { sample }\end{array}$} & \multirow{2}{*}{$\begin{array}{c}\text { General } \\
\text { land }\end{array}$} & \multicolumn{3}{|c|}{ Māori Freehold land } \\
\hline & & & Total & $\begin{array}{c}\text { Without } \\
\text { structure }\end{array}$ & $\begin{array}{c}\text { With } \\
\text { structure }\end{array}$ \\
\hline \multicolumn{6}{|l|}{ Sample distribution } \\
\hline Pixels & 673,483 & 630,290 & 43,193 & 7,335 & 35,858 \\
\hline Share & $100 \%$ & $93.6 \%$ & $6.4 \%$ & $17.0 \%$ & $83.0 \%$ \\
\hline \multicolumn{6}{|l|}{ Land-cover shares 1997} \\
\hline Horticulture & $2.5 \%$ & $2.6 \%$ & $1.0 \%$ & $1.5 \%$ & $0.8 \%$ \\
\hline Pasture & $67.4 \%$ & $69.6 \%$ & $34.9 \%$ & $37.9 \%$ & $34.3 \%$ \\
\hline Forestry & $10.8 \%$ & $10.7 \%$ & $13.6 \%$ & $3.9 \%$ & $15.5 \%$ \\
\hline Scrub & $10.2 \%$ & $9.4 \%$ & $21.6 \%$ & $27.7 \%$ & $20.4 \%$ \\
\hline Indigenous Forest & $9.0 \%$ & $7.7 \%$ & $28.9 \%$ & $29.0 \%$ & $28.9 \%$ \\
\hline \multicolumn{6}{|l|}{ Land-cover shares 2012} \\
\hline Horticulture & $2.8 \%$ & $2.9 \%$ & $1.0 \%$ & $1.7 \%$ & $0.9 \%$ \\
\hline Pasture & $66.3 \%$ & $68.5 \%$ & $33.8 \%$ & $36.7 \%$ & $33.2 \%$ \\
\hline Forestry & $12.1 \%$ & $12.0 \%$ & $14.6 \%$ & $4.6 \%$ & $16.6 \%$ \\
\hline Scrub & $9.9 \%$ & $9.0 \%$ & $21.8 \%$ & $28.1 \%$ & $20.5 \%$ \\
\hline Indigenous Forest & $9.0 \%$ & $7.6 \%$ & $28.9 \%$ & $29.0 \%$ & $28.9 \%$ \\
\hline \multicolumn{6}{|l|}{ Land use capability (LUC) } \\
\hline LUC class 1 & $1.1 \%$ & $1.1 \%$ & $0.6 \%$ & $1.0 \%$ & $0.5 \%$ \\
\hline LUC class 2 & $6.9 \%$ & $7.2 \%$ & $2.5 \%$ & $4.7 \%$ & $2.1 \%$ \\
\hline LUC class 3 & $14.0 \%$ & $14.6 \%$ & $6.1 \%$ & $8.6 \%$ & $5.6 \%$ \\
\hline LUC class 4 & $14.6 \%$ & $15.0 \%$ & $9.4 \%$ & $10.5 \%$ & $9.2 \%$ \\
\hline LUC class 5 & $1.1 \%$ & $1.2 \%$ & $0.6 \%$ & $0.9 \%$ & $0.5 \%$ \\
\hline LUC class 6 & $37.2 \%$ & $37.3 \%$ & $35.7 \%$ & $39.9 \%$ & $34.8 \%$ \\
\hline LUC class 7 & $20.7 \%$ & $19.8 \%$ & $33.5 \%$ & $27.2 \%$ & $34.4 \%$ \\
\hline LUC class 8 & $4.4 \%$ & $3.9 \%$ & $11.7 \%$ & $5.3 \%$ & $12.9 \%$ \\
\hline \multicolumn{6}{|l|}{ Slope of the land } \\
\hline Mean & 10 & 9 & 12 & 11 & 13 \\
\hline Std. Dev. & 9 & 9 & 9 & 8 & 9 \\
\hline Min & 0 & 0 & 0 & 0 & 0 \\
\hline Max & 63 & 63 & 52 & 42 & 52 \\
\hline \multicolumn{6}{|l|}{ Distance to supermarkets } \\
\hline Mean & 5.8 & 5.6 & 8.5 & 6.0 & 9.1 \\
\hline Std. Dev. & 6.5 & 6.3 & 8.4 & 6.2 & 8.7 \\
\hline Min & 0.0 & 0.0 & 0.1 & 0.1 & 0.1 \\
\hline Max & 61.8 & 61.8 & 54.7 & 51.6 & 54.7 \\
\hline \multicolumn{6}{|l|}{ Distance to ports } \\
\hline Mean & 13.9 & 13.8 & 16.6 & 14.4 & 17.0 \\
\hline Std. Dev. & 8.6 & 8.5 & 9.4 & 7.5 & 9.7 \\
\hline Min & 0.0 & 0.0 & 0.3 & 0.5 & 0.3 \\
\hline Max & 75.5 & 75.5 & 64.7 & 62.5 & 64.7 \\
\hline \multicolumn{6}{|l|}{ North Island } \\
\hline Pixels & 363,113 & 321,506 & 41,607 & 6,953 & 34,654 \\
\hline Share & $53.9 \%$ & $50.0 \%$ & $96.3 \%$ & $94.8 \%$ & $96.6 \%$ \\
\hline
\end{tabular}


Table 3-3 Concordances between land-cover classes and land-cover categories

\begin{tabular}{|c|c|c|c|c|}
\hline Land-cover classes & \multicolumn{4}{|c|}{ Land-cover categories (from the LCDB) } \\
\hline \multirow[t]{2}{*}{ Urban } & 1 & Built-up area & 5 & Transport infrastructure \\
\hline & 2 & Urban parkland / open space & & \\
\hline Horticulture & 30 & Short-rotation cropland & 33 & $\begin{array}{l}\text { Orchard, vineyard and other } \\
\text { perennial crops }\end{array}$ \\
\hline \multirow[t]{2}{*}{ Pasture } & 40 & High producing exotic grassland & 43 & Tall tussock grassland \\
\hline & 41 & Low producing grassland & 44 & Depleted tussock grassland \\
\hline \multirow[t]{2}{*}{ Forestry } & 64 & Forest harvested & 71 & Exotic forest \\
\hline & 68 & Deciduous hardwoods & & \\
\hline \multirow[t]{4}{*}{ Scrub } & 47 & Flaxland & 54 & $\begin{array}{l}\text { Broadleaved indigenous } \\
\text { hardwoods }\end{array}$ \\
\hline & 50 & Fernland & 55 & Sub-alpine scrubland \\
\hline & 51 & Gorse and/or broom & 56 & Mixed exotic scrubland \\
\hline & 52 & Mānuka and/or kānuka & 58 & Matagouri or grey scrub \\
\hline Indigenous forest & 69 & Indigenous forest & & \\
\hline \multirow[t]{6}{*}{ Non-productive } & 6 & Surface mines and dumps & 20 & Lake and pond \\
\hline & 10 & Sand and gravel & 21 & River \\
\hline & 12 & Landslide & 22 & Estuarine open water \\
\hline & 14 & Permanent ice and snow & 45 & $\begin{array}{l}\text { Herbaceous freshwater } \\
\text { vegetation }\end{array}$ \\
\hline & 15 & Alpine grass / herb field & 46 & Herbaceous saline vegetation \\
\hline & 16 & Gravel and rock & 70 & Mangrove \\
\hline
\end{tabular}


Table 3-4 Transition matrix: land-cover transitions 1997 to 2012 (pixels and shares)

\begin{tabular}{|c|c|c|c|c|c|c|c|}
\hline \multirow{2}{*}{\multicolumn{2}{|c|}{ Land cover in 1997}} & \multicolumn{5}{|c|}{ Land cover in 2012} & \multirow{2}{*}{$\begin{array}{l}1997 \\
\text { Total }\end{array}$} \\
\hline & & Horticulture & & & Scrub & $\begin{array}{c}\text { Indigenous } \\
\text { forest }\end{array}$ & \\
\hline \multirow{8}{*}{ Horticulture } & \multirow{2}{*}{ General land } & 16,317 & 180 & 10 & - & - & 16,507 \\
\hline & & $98.8 \%$ & $1.1 \%$ & $0.1 \%$ & - & - & \\
\hline & \multirow{2}{*}{ Māori freehold land } & 407 & 2 & 1 & - & - & 410 \\
\hline & & $99.3 \%$ & $0.5 \%$ & $0.2 \%$ & - & - & \\
\hline & \multirow{2}{*}{ With structure } & 294 & 2 & 1 & - & - & 297 \\
\hline & & $99.0 \%$ & $0.7 \%$ & $0.3 \%$ & - & - & \\
\hline & \multirow{2}{*}{ Without structure } & 113 & - & - & - & - & 113 \\
\hline & & $100 \%$ & - & - & - & - & \\
\hline \multirow{8}{*}{ Pasture } & \multirow{2}{*}{ General land } & 1,839 & 425,959 & 9,480 & 1,656 & 1 & 438,935 \\
\hline & & $0.4 \%$ & $97.0 \%$ & $2.2 \%$ & $0.4 \%$ & $0.0 \%$ & \\
\hline & \multirow{2}{*}{ Māori freehold land } & 32 & 14,368 & 361 & 328 & - & 15,089 \\
\hline & & $0.2 \%$ & $95.2 \%$ & $2.4 \%$ & $2.2 \%$ & - & \\
\hline & \multirow{2}{*}{ With structure } & 20 & 11,719 & 315 & 256 & - & 12,310 \\
\hline & & $0.2 \%$ & $95.2 \%$ & $2.6 \%$ & $2.1 \%$ & - & \\
\hline & \multirow{2}{*}{ Without structure } & 12 & 2,649 & 46 & 72 & - & 2,779 \\
\hline & & $0 \%$ & $95.32 \%$ & $1.66 \%$ & $2.59 \%$ & - & \\
\hline \multirow{8}{*}{ Forestry } & \multirow{2}{*}{ General land } & 31 & 3,123 & 63,756 & 265 & - & 67,175 \\
\hline & & $0.0 \%$ & $4.6 \%$ & $94.9 \%$ & $0.4 \%$ & - & \\
\hline & \multirow{2}{*}{ Māori freehold land } & - & 83 & 5,767 & 10 & - & 5,860 \\
\hline & & - & $1.4 \%$ & $98.4 \%$ & $0.2 \%$ & - & \\
\hline & \multirow{2}{*}{ With structure } & - & 73 & 5,491 & 10 & - & 5,574 \\
\hline & & - & $1.3 \%$ & $98.5 \%$ & $0.2 \%$ & - & \\
\hline & Without structuro & - & 10 & 276 & - & - & 286 \\
\hline & Without structure & - & $3.50 \%$ & $96.50 \%$ & - & - & \\
\hline & & 13 & 2,373 & 2,036 & 55,051 & 6 & 59,479 \\
\hline & General land & $0.0 \%$ & $4.0 \%$ & $3.4 \%$ & $92.6 \%$ & $0.0 \%$ & \\
\hline & & - & 126 & 141 & 9,068 & 1 & 9,336 \\
\hline Scrub & Maori freehold land & - & $1.3 \%$ & $1.5 \%$ & $97.1 \%$ & $0.0 \%$ & \\
\hline Scrub & With structure & - & 99 & 124 & 7,082 & 1 & 7,306 \\
\hline & With structure & - & $1.4 \%$ & $1.7 \%$ & $96.9 \%$ & $0.0 \%$ & \\
\hline & Without structure & - & 27 & 17 & 1,986 & - & 2,030 \\
\hline & Without structure & - & $1.33 \%$ & $0.84 \%$ & $97.8 \%$ & - & \\
\hline & Ceneral land & - & 164 & 84 & 31 & 47,915 & 48,194 \\
\hline & General land & - & $0.3 \%$ & $0.2 \%$ & $0.1 \%$ & $99.4 \%$ & \\
\hline & & - & 5 & 16 & 9 & 12,468 & 12,498 \\
\hline Indigenous & Māori freehold land & - & $0.0 \%$ & $0.1 \%$ & $0.1 \%$ & $99.8 \%$ & \\
\hline forest & With structure & - & 3 & 16 & 9 & 10,343 & 10,371 \\
\hline & With structure & - & $0.0 \%$ & $0.2 \%$ & $0.1 \%$ & $99.7 \%$ & \\
\hline & & - & 2 & - & - & 2,125 & 2,127 \\
\hline & Without structure & - & $0.09 \%$ & - & - & $99.91 \%$ & \\
\hline & General land & 18,200 & 431,799 & 75,366 & 57,003 & 47,922 & 630,290 \\
\hline & Māori freehold land & 439 & 14,584 & 6,286 & 9,415 & 12,469 & 43,193 \\
\hline Total & With structure & 314 & 11,896 & 5,947 & 7,357 & 10,344 & 35,858 \\
\hline & Without structure & 125 & 2,688 & 339 & 2,058 & 2,125 & 7,335 \\
\hline
\end{tabular}

Note: Read the table horizontally to see how pixels that were in a particular land-cover in 1997 were subsequently allocated in 2012. Read the table vertically to see how pixels that were in a particular land-cover in 2012 were previously allocated in 1997. 
Table 3-5 Māori freehold land by Māori Land Court districts

\begin{tabular}{llllllll}
\hline \multirow{2}{*}{ District } & \multicolumn{7}{c}{ Māori freehold land } \\
\cline { 2 - 7 } & \multicolumn{1}{c}{ With structure } & Without structure & \multicolumn{2}{c}{ Total } \\
\cline { 2 - 7 } & Pixels & \% & Pixels & \% & Pixels & \% \\
\hline Aotea & 10,625 & $29.8 \%$ & 1,315 & $17.9 \%$ & 11,940 & $27.8 \%$ \\
Tai Tokerau & 2,513 & $7 \%$ & 1,916 & $26.1 \%$ & 4,429 & $10.3 \%$ \\
Tairawhiti & 7,252 & $20.3 \%$ & 1,420 & $19.4 \%$ & 8,672 & $20.2 \%$ \\
Takitimu & 2,752 & $7.7 \%$ & 611 & $8.3 \%$ & 3,363 & $7.8 \%$ \\
Te Wai Pounamu & 1,204 & $3.4 \%$ & 382 & $5.2 \%$ & 1,586 & $3.7 \%$ \\
Waiariki & 8,180 & $22.9 \%$ & 682 & $9.3 \%$ & 8,862 & $20.6 \%$ \\
Waiakato-Maniapoto & 3,149 & $8.8 \%$ & 1,009 & $13.8 \%$ & 4,158 & $9.7 \%$ \\
\hline Total & 35,675 & $83 \%$ & 7,335 & $17 \%$ & 43,010 & $100 \%$ \\
\hline
\end{tabular}


Table 3-6 Average marginal effects (AME) for land-cover shares 2012 - Māori freehold land relative to general land

\begin{tabular}{|c|c|c|c|c|c|c|c|c|c|c|c|c|c|c|c|}
\hline & \multicolumn{3}{|c|}{ Horticulture } & \multicolumn{3}{|c|}{ Pasture } & \multicolumn{3}{|c|}{ Forestry } & \multicolumn{3}{|c|}{ Scrub } & \multicolumn{3}{|c|}{ Indigenous forest } \\
\hline & (1) & (2) & (3) & (1) & (2) & (3) & (1) & (2) & (3) & (1) & (2) & (3) & (1) & (2) & (3) \\
\hline Māori freehold land & $\begin{array}{c}0.014^{* * *} \\
(0.002)\end{array}$ & $\begin{array}{c}0.018^{* * *} \\
(0.005)\end{array}$ & $\begin{array}{l}0.011^{* *} \\
(0.005)\end{array}$ & $\begin{array}{c}-0.205^{* * *} \\
(0.003)\end{array}$ & $\begin{array}{c}-0.204^{* * *} \\
(0.008)\end{array}$ & $\begin{array}{c}-0.188^{* * *} \\
(0.008)\end{array}$ & $\begin{array}{c}0.009^{* * *} \\
(0.002)\end{array}$ & $\begin{array}{c}0.007 \\
(0.005)\end{array}$ & $\begin{array}{c}0.008 \\
(0.005)\end{array}$ & $\begin{array}{c}0.110^{* * *} \\
(0.002)\end{array}$ & $\begin{array}{c}0.109^{* * *} \\
(0.006)\end{array}$ & $\begin{array}{c}0.099^{* * *} \\
(0.006)\end{array}$ & $\begin{array}{c}0.072^{* * *} \\
(0.001)\end{array}$ & $\begin{array}{c}0.070^{* * *} \\
(0.004)\end{array}$ & $\begin{array}{l}0.070^{* * * *} \\
(0.004)\end{array}$ \\
\hline Land use capability (LUC) & & & & & & & & & & & & & & & \\
\hline LUC classes 1-2 & $\begin{array}{c}0.041^{* * *} \\
(0.001)\end{array}$ & $\begin{array}{c}0.040^{* * *} \\
(0.003)\end{array}$ & $\begin{array}{c}0.041^{* * *} \\
(0.003)\end{array}$ & $\begin{array}{c}0.365^{* * *} \\
(0.002)\end{array}$ & $\begin{array}{c}0.369^{* * *} \\
(0.007)\end{array}$ & $\begin{array}{c}0.365^{* * *} \\
(0.007)\end{array}$ & $\begin{array}{c}-0.185^{* * *} \\
(0.002)\end{array}$ & $\begin{array}{c}-0.185^{* * *} \\
(0.005)\end{array}$ & $\begin{array}{c}-0.184^{* * *} \\
(0.005)\end{array}$ & $\begin{array}{c}-0.111^{* * *} \\
(0.001)\end{array}$ & $\begin{array}{c}-0.111^{* * *} \\
(0.004)\end{array}$ & $\begin{array}{c}-0.111^{* * *} \\
(0.004)\end{array}$ & $\begin{array}{c}-0.110^{* * *} \\
(0.001)\end{array}$ & $\begin{array}{c}-0.114^{* * *} \\
(0.004)\end{array}$ & $\begin{array}{c}-0.110^{* * *} \\
(0.004)\end{array}$ \\
\hline LUC class 3 & $\begin{array}{c}0.019^{* * *} \\
(0.001)\end{array}$ & $\begin{array}{c}0.018^{* * *} \\
(0.003)\end{array}$ & $\begin{array}{c}0.020^{* * *} \\
(0.003)\end{array}$ & $\begin{array}{c}0.326^{* * *} \\
(0.002)\end{array}$ & $\begin{array}{c}0.332^{* * *} \\
(0.007)\end{array}$ & $\begin{array}{c}0.323^{* * *} \\
(0.007)\end{array}$ & $\begin{array}{c}-0.153^{* * *} \\
(0.002)\end{array}$ & $\begin{array}{c}-0.155^{* * *} \\
(0.005)\end{array}$ & $\begin{array}{c}-0.153^{* * *} \\
(0.005)\end{array}$ & $\begin{array}{c}-0.096^{* * *} \\
(0.001)\end{array}$ & $\begin{array}{c}-0.096^{* * *} \\
(0.004)\end{array}$ & $\begin{array}{c}-0.096^{* * *} \\
(0.004)\end{array}$ & $\begin{array}{c}-0.096^{* * *} \\
(0.001)\end{array}$ & $\begin{array}{c}-0.099 * * * \\
(0.004)\end{array}$ & $\begin{array}{c}-0.094^{* * *} \\
(0.004)\end{array}$ \\
\hline LUC class 4 & $\begin{array}{c}0.001 \\
(0.001)\end{array}$ & $\begin{array}{c}-0.000 \\
(0.003)\end{array}$ & $\begin{array}{c}0.002 \\
(0.002)\end{array}$ & $\begin{array}{c}0.211^{* * *} \\
(0.002)\end{array}$ & $\begin{array}{c}0.212^{* * *} \\
(0.007)\end{array}$ & $\begin{array}{c}0.208^{* * *} \\
(0.007)\end{array}$ & $\begin{array}{c}-0.081^{* * *} \\
(0.002)\end{array}$ & $\begin{array}{c}-0.079 * * * \\
(0.006)\end{array}$ & $\begin{array}{c}-0.081^{* * *} \\
(0.006)\end{array}$ & $\begin{array}{c}-0.068^{* * *} \\
(0.001)\end{array}$ & $\begin{array}{c}-0.068^{* * *} \\
(0.004)\end{array}$ & $\begin{array}{c}-0.067^{* * *} \\
(0.004)\end{array}$ & $\begin{array}{c}-0.063^{* * *} \\
(0.001)\end{array}$ & $\begin{array}{c}-0.065^{* * *} \\
(0.004)\end{array}$ & $\begin{array}{c}-0.061^{* * *} \\
(0.004)\end{array}$ \\
\hline LUC classes $5-6$ & $\begin{array}{c}-0.004^{* * *} \\
(0.001)\end{array}$ & $\begin{array}{c}-0.005^{* *} \\
(0.003)\end{array}$ & $\begin{array}{l}-0.002 \\
(0.002)\end{array}$ & $\begin{array}{c}0.123^{* * *} \\
(0.002)\end{array}$ & $\begin{array}{l}0.125^{* * *} \\
(0.005)\end{array}$ & $\begin{array}{c}0.115^{* * *} \\
(0.005)\end{array}$ & $\begin{array}{c}-0.056^{* * *} \\
(0.002)\end{array}$ & $\begin{array}{c}-0.058^{* * *} \\
(0.005)\end{array}$ & $\begin{array}{c}-0.052^{* * *} \\
(0.005)\end{array}$ & $\begin{array}{c}-0.017^{* * *} \\
(0.001)\end{array}$ & $\begin{array}{c}-0.012^{* * *} \\
(0.003)\end{array}$ & $\begin{array}{c}-0.014^{* * *} \\
(0.003)\end{array}$ & $\begin{array}{c}-0.047^{* * *} \\
(0.001)\end{array}$ & $\begin{array}{c}-0.049 * * * \\
(0.003)\end{array}$ & $\begin{array}{c}-0.047^{* * *} \\
(0.003)\end{array}$ \\
\hline Slope of the land & $\begin{array}{c}-0.006^{* * *} \\
(0.000)\end{array}$ & $\begin{array}{c}-0.006^{* * *} \\
(0.000)\end{array}$ & $\begin{array}{c}-0.006^{* * *} \\
(0.000)\end{array}$ & $\begin{array}{c}-0.001^{* * *} \\
(0.000)\end{array}$ & $\begin{array}{l}-0.001 \\
(0.000)\end{array}$ & $\begin{array}{c}-0.001^{* * *} \\
(0.000)\end{array}$ & $\begin{array}{c}-0.001^{* * *} \\
(0.000)\end{array}$ & $\begin{array}{c}-0.001^{* * *} \\
(0.000)\end{array}$ & $\begin{array}{c}-0.001^{* * *} \\
(0.000)\end{array}$ & $\begin{array}{c}0.005^{* * *} \\
(0.000)\end{array}$ & $\begin{array}{c}0.005^{* * *} \\
(0.000)\end{array}$ & $\begin{array}{c}0.005^{* * *} \\
(0.000)\end{array}$ & $\begin{array}{c}0.004^{* * *} \\
(0.000)\end{array}$ & $\begin{array}{c}0.003^{* * *} \\
(0.000)\end{array}$ & $\begin{array}{c}0.004^{* * *} \\
(0.000)\end{array}$ \\
\hline Distance to supermarkets & $\begin{array}{c}-0.005^{* * *} \\
(0.000)\end{array}$ & $\begin{array}{c}-0.005^{* * *} \\
(0.001)\end{array}$ & $\begin{array}{c}-0.005^{* * *} \\
(0.001)\end{array}$ & $\begin{array}{c}0.005^{* * *} \\
(0.000)\end{array}$ & $\begin{array}{l}0.004 * * * \\
(0.001)\end{array}$ & $\begin{array}{c}0.005^{* * *} \\
(0.001)\end{array}$ & $\begin{array}{c}0.000 \\
(0.000)\end{array}$ & $\begin{array}{c}-0.000 \\
(0.000)\end{array}$ & $\begin{array}{c}-0.000 \\
(0.000)\end{array}$ & $\begin{array}{c}-0.001^{* * *} \\
(0.000)\end{array}$ & $\begin{array}{c}-0.002^{* * *} \\
(0.000)\end{array}$ & $\begin{array}{c}-0.001^{* * *} \\
(0.000)\end{array}$ & $\begin{array}{l}0.002^{* * *} \\
(0.000)\end{array}$ & $\begin{array}{c}0.002^{* * *} \\
(0.000)\end{array}$ & $\begin{array}{c}0.002^{* * *} \\
(0.000)\end{array}$ \\
\hline Distance to ports & $\begin{array}{c}-0.002^{* * *} \\
(0.000)\end{array}$ & $\begin{array}{c}-0.002^{* * *} \\
(0.000)\end{array}$ & $\begin{array}{c}-0.002^{* * *} \\
(0.000)\end{array}$ & $\begin{array}{l}0.005^{* * *} \\
(0.000)\end{array}$ & $\begin{array}{l}0.006 \text { *** } \\
(0.000)\end{array}$ & $\begin{array}{c}0.005^{* * *} \\
(0.000)\end{array}$ & $\begin{array}{c}-0.005^{* * *} \\
(0.000)\end{array}$ & $\begin{array}{c}-0.005^{* * *} \\
(0.000)\end{array}$ & $\begin{array}{c}-0.004^{* * *} \\
(0.000)\end{array}$ & $\begin{array}{c}0.000^{* * *} \\
(0.000)\end{array}$ & $\begin{array}{c}0.001^{* * *} \\
(0.000)\end{array}$ & $\begin{array}{c}0.000 \\
(0.000)\end{array}$ & $\begin{array}{l}0.001^{* * *} \\
(0.000)\end{array}$ & $\begin{array}{c}0.001^{* * *} \\
(0.000)\end{array}$ & $\begin{array}{c}0.001^{* * *} \\
(0.000)\end{array}$ \\
\hline North Island & $\begin{array}{c}-0.020^{* * *} \\
(0.000)\end{array}$ & $\begin{array}{c}-0.020^{* * *} \\
(0.001)\end{array}$ & $\begin{array}{c}-0.020^{* * *} \\
(0.001)\end{array}$ & $\begin{array}{c}-0.119 * * * \\
(0.001)\end{array}$ & $\begin{array}{c}-0.117^{* * *} \\
(0.003)\end{array}$ & $\begin{array}{c}-0.125^{* * *} \\
(0.003)\end{array}$ & $\begin{array}{c}0.051^{* * *} \\
(0.001)\end{array}$ & $\begin{array}{c}0.050^{* * *} \\
(0.003)\end{array}$ & $\begin{array}{c}0.056^{* * *} \\
(0.003)\end{array}$ & $\begin{array}{c}-0.002^{* * *} \\
(0.001)\end{array}$ & $\begin{array}{c}-0.003 \\
(0.002)\end{array}$ & $\begin{array}{l}-0.002 \\
(0.002)\end{array}$ & $\begin{array}{c}0.090^{* * *} \\
(0.001)\end{array}$ & $\begin{array}{c}0.090^{* * *} \\
(0.002)\end{array}$ & $\begin{array}{c}0.091^{* * * *} \\
(0.002)\end{array}$ \\
\hline Observations & 673,483 & 74,900 & 74,900 & 673,483 & 74,900 & 74,900 & 673,483 & 74,900 & 74,900 & 673,483 & 74,900 & 74,900 & 673,483 & 74,900 & 74,900 \\
\hline
\end{tabular}

Robust standard errors in parentheses

${ }^{* * *} \mathrm{p}<0.01,{ }^{* *} \mathrm{p}<0.05,{ }^{*} \mathrm{p}<0.1$

Note: In Column 2, the sample is restricted to the spatial sample 'SG3', which I draw by selecting every third pixel in the X-and Y-direction. In Column 3, the sample is restricted to the random

spatial sample 'RS' by selecting a random sample size based on SG3. 
Table 3-7 AME for land-cover shares 2012 - Māori freehold land with structure relative to Māori freehold land without structure

\begin{tabular}{|c|c|c|c|c|c|c|c|c|c|c|c|c|c|c|c|}
\hline & \multicolumn{3}{|c|}{ Horticulture } & \multicolumn{3}{|c|}{ Pasture } & \multicolumn{3}{|c|}{ Forestry } & \multicolumn{3}{|c|}{ Scrub } & \multicolumn{3}{|c|}{ Indigenous forest } \\
\hline & (1) & (2) & (3) & (1) & (2) & (3) & (1) & (2) & (3) & (1) & (2) & (3) & (1) & (2) & (3) \\
\hline Māori freehold land with structure & $\begin{array}{c}-0.002 \\
(0.003)\end{array}$ & $\begin{array}{c}-0.002 \\
(0.007)\end{array}$ & $\begin{array}{l}-0.005 \\
(0.007)\end{array}$ & $\begin{array}{c}-0.112^{* * *} \\
(0.010)\end{array}$ & $\begin{array}{c}-0.132^{* * *} \\
(0.031)\end{array}$ & $\begin{array}{c}-0.207^{* * *} \\
(0.036)\end{array}$ & $\begin{array}{c}0.195^{* * *} \\
(0.011)\end{array}$ & $\begin{array}{l}0.217^{* * *} \\
(0.035)\end{array}$ & $\begin{array}{c}0.299^{* * *} \\
(0.043)\end{array}$ & $\begin{array}{c}-0.046^{* * *} \\
(0.002)\end{array}$ & $\begin{array}{c}-0.045^{* * *} \\
(0.005)\end{array}$ & $\begin{array}{c}-0.049 * * * \\
(0.006)\end{array}$ & $\begin{array}{c}-0.036^{* * *} \\
(0.002)\end{array}$ & $\begin{array}{c}-0.038^{* * *} \\
(0.005)\end{array}$ & $\begin{array}{c}-0.038^{* * *} \\
(0.005)\end{array}$ \\
\hline Māori freehold land & $\begin{array}{c}0.015^{* * *} \\
(0.003)\end{array}$ & $\begin{array}{c}0.019^{*} \\
(0.010)\end{array}$ & $\begin{array}{c}0.014 \\
(0.009)\end{array}$ & $\begin{array}{c}-0.207^{* * *} \\
(0.006)\end{array}$ & $\begin{array}{c}-0.199^{* * *} \\
(0.018)\end{array}$ & $\begin{array}{c}-0.156^{* * *} \\
(0.018)\end{array}$ & $\begin{array}{c}-0.088^{* * *} \\
(0.003)\end{array}$ & $\begin{array}{c}-0.093^{* * *} \\
(0.008)\end{array}$ & $\begin{array}{c}-0.108^{* * *} \\
(0.008)\end{array}$ & $\begin{array}{c}0.173^{* * *} \\
(0.005)\end{array}$ & $\begin{array}{c}0.165^{* * *} \\
(0.014)\end{array}$ & $\begin{array}{c}0.151^{* * *} \\
(0.013)\end{array}$ & $\begin{array}{c}0.107^{* * *} \\
(0.003)\end{array}$ & $\begin{array}{c}0.108^{* * *} \\
(0.010)\end{array}$ & $\begin{array}{l}0.100^{* * *} \\
(0.010)\end{array}$ \\
\hline Id use capa & & & & & & & & & & & & & & & \\
\hline LUC c & $\begin{array}{c}-0.002 \\
(0.003)\end{array}$ & $\begin{array}{c}0.040^{* * *} \\
(0.003)\end{array}$ & $\begin{array}{l}-0.005 \\
(0.007)\end{array}$ & $\begin{array}{c}-0.112^{* * *} \\
(0.010)\end{array}$ & $\begin{array}{c}0.369 * * * \\
(0.007)\end{array}$ & $\begin{array}{c}-0.207^{* * *} \\
(0.036)\end{array}$ & $\begin{array}{c}0.195^{* * *} \\
(0.011)\end{array}$ & $\begin{array}{c}-0.184^{* * *} \\
(0.005)\end{array}$ & $\begin{array}{c}0.299^{* * *} \\
(0.043)\end{array}$ & $\begin{array}{c}-0.046^{* * *} \\
(0.002)\end{array}$ & $\begin{array}{c}-0.111^{* * *} \\
(0.004)\end{array}$ & $\begin{array}{c}-0.049 * * * \\
(0.006)\end{array}$ & $\begin{array}{c}-0.036^{* * *} \\
(0.002)\end{array}$ & $\begin{array}{c}-0.114^{* * *} \\
(0.004)\end{array}$ & $\begin{array}{c}-0.038^{* * *} \\
(0.005)\end{array}$ \\
\hline LUC class 3 & $\begin{array}{c}0.041^{* * *} \\
(0.001)\end{array}$ & $\begin{array}{c}0.018^{* * *} \\
(0.003)\end{array}$ & $\begin{array}{c}0.041^{* * *} \\
(0.003)\end{array}$ & $\begin{array}{c}0.365^{* * *} \\
(0.002)\end{array}$ & $\begin{array}{l}0.332^{* * *} \\
(0.007)\end{array}$ & $\begin{array}{c}0.365^{* * *} \\
(0.007)\end{array}$ & $\begin{array}{c}-0.184^{* * *} \\
(0.002)\end{array}$ & $\begin{array}{c}-0.154^{* * *} \\
(0.005)\end{array}$ & $\begin{array}{c}-0.184^{* * *} \\
(0.005)\end{array}$ & $\begin{array}{c}-0.112^{* * *} \\
(0.001)\end{array}$ & $\begin{array}{c}-0.096^{* * *} \\
(0.004)\end{array}$ & $\begin{array}{c}-0.111^{* * *} \\
(0.004)\end{array}$ & $\begin{array}{c}-0.111^{* * *} \\
(0.001)\end{array}$ & $\begin{array}{c}-0.099 * * * \\
(0.004)\end{array}$ & $\begin{array}{c}-0.111^{* * *} \\
(0.004)\end{array}$ \\
\hline LUC c & $\begin{array}{c}0.019 * * * \\
(0.001)\end{array}$ & $\begin{array}{c}-0.000 \\
(0.003)\end{array}$ & $\begin{array}{c}0.020^{* * *} \\
(0.003)\end{array}$ & $\begin{array}{c}0.326^{* * *} \\
(0.002)\end{array}$ & $\begin{array}{l}0.212^{* * *} \\
(0.007)\end{array}$ & $\begin{array}{c}0.322^{* * *} \\
(0.007)\end{array}$ & $\begin{array}{c}-0.153^{* * *} \\
(0.002)\end{array}$ & $\begin{array}{c}-0.079 * * * \\
(0.006)\end{array}$ & $\begin{array}{c}-0.153^{* * *} \\
(0.005)\end{array}$ & $\begin{array}{c}-0.097^{* * *} \\
(0.001)\end{array}$ & $\begin{array}{c}-0.068^{* * *} \\
(0.004)\end{array}$ & $\begin{array}{c}-0.096^{* * *} \\
(0.004)\end{array}$ & $\begin{array}{c}-0.096^{* * *} \\
(0.001)\end{array}$ & $\begin{array}{c}-0.065^{* * *} \\
(0.004)\end{array}$ & $\begin{array}{c}-0.094^{* * *} \\
(0.004)\end{array}$ \\
\hline LUC classes $5-6$ & $\begin{array}{c}0.001 \\
(0.001)\end{array}$ & $\begin{array}{c}-0.005^{* *} \\
(0.003)\end{array}$ & $\begin{array}{c}0.002 \\
(0.002)\end{array}$ & $\begin{array}{c}0.211^{* * *} \\
(0.002)\end{array}$ & $\begin{array}{l}0.125^{* * *} \\
(0.005)\end{array}$ & $\begin{array}{c}0.208^{* * *} \\
(0.007)\end{array}$ & $\begin{array}{c}-0.081^{* * *} \\
(0.002)\end{array}$ & $\begin{array}{c}-0.058^{* * *} \\
(0.005)\end{array}$ & $\begin{array}{c}-0.081^{* * *} \\
(0.006)\end{array}$ & $\begin{array}{c}-0.068^{* * *} \\
(0.001)\end{array}$ & $\begin{array}{c}-0.012^{* * *} \\
(0.003)\end{array}$ & $\begin{array}{c}-0.068^{* * *} \\
(0.004)\end{array}$ & $\begin{array}{c}-0.064^{* * *} \\
(0.001)\end{array}$ & $\begin{array}{c}-0.049^{* * *} \\
(0.003)\end{array}$ & $\begin{array}{c}-0.062^{* * *} \\
(0.004)\end{array}$ \\
\hline Slope of the land & $\begin{array}{c}-0.006^{* * *} \\
(0.000)\end{array}$ & $\begin{array}{c}-0.006^{* * *} \\
(0.000)\end{array}$ & $\begin{array}{c}-0.006^{* * *} \\
(0.000)\end{array}$ & $\begin{array}{c}-0.001^{* * *} \\
(0.000)\end{array}$ & $\begin{array}{c}-0.001 \\
(0.000)\end{array}$ & $\begin{array}{c}-0.001^{* * *} \\
(0.000)\end{array}$ & $\begin{array}{c}-0.001^{* * *} \\
(0.000)\end{array}$ & $\begin{array}{c}-0.001^{* * *} \\
(0.000)\end{array}$ & $\begin{array}{c}-0.001^{* * *} \\
(0.000)\end{array}$ & $\begin{array}{c}0.005^{* * *} \\
(0.000)\end{array}$ & $\begin{array}{c}0.005^{* * *} \\
(0.000)\end{array}$ & $\begin{array}{c}0.005^{* * *} \\
(0.000)\end{array}$ & $\begin{array}{c}0.004^{* * *} \\
(0.000)\end{array}$ & $\begin{array}{c}0.003^{* * *} \\
(0.000)\end{array}$ & $\begin{array}{l}0.004^{* * *} \\
(0.000)\end{array}$ \\
\hline Distance to supermarkets & $\begin{array}{c}-0.005^{* * *} \\
(0.000)\end{array}$ & $\begin{array}{c}-0.005^{* * *} \\
(0.001)\end{array}$ & $\begin{array}{c}-0.005^{* * *} \\
(0.001)\end{array}$ & $\begin{array}{c}0.005^{* * *} \\
(0.000)\end{array}$ & $\begin{array}{l}0.005^{* * *} \\
(0.001)\end{array}$ & $\begin{array}{c}0.005^{* * *} \\
(0.001)\end{array}$ & $\begin{array}{l}-0.000 \\
(0.000)\end{array}$ & $\begin{array}{c}-0.000 \\
(0.000)\end{array}$ & $\begin{array}{c}-0.000 \\
(0.000)\end{array}$ & $\begin{array}{c}-0.001^{* * *} \\
(0.000)\end{array}$ & $\begin{array}{c}-0.002^{* * *} \\
(0.000)\end{array}$ & $\begin{array}{c}-0.001^{* * *} \\
(0.000)\end{array}$ & $\begin{array}{c}0.002^{* * *} \\
(0.000)\end{array}$ & $\begin{array}{c}0.002^{* * *} \\
(0.000)\end{array}$ & $\begin{array}{l}0.002^{* * *} \\
(0.000)\end{array}$ \\
\hline Distance to ports & $\begin{array}{c}-0.002^{* * *} \\
(0.000)\end{array}$ & $\begin{array}{c}-0.002^{* * *} \\
(0.000)\end{array}$ & $\begin{array}{c}-0.002^{* * *} \\
(0.000)\end{array}$ & $\begin{array}{c}0.005^{* * *} \\
(0.000)\end{array}$ & $\begin{array}{l}0.006^{* * *} \\
(0.000)\end{array}$ & $\begin{array}{c}0.005^{* * *} \\
(0.000)\end{array}$ & $\begin{array}{c}-0.005^{* * *} \\
(0.000)\end{array}$ & $\begin{array}{c}-0.005^{* * *} \\
(0.000)\end{array}$ & $\begin{array}{c}-0.004^{* * *} \\
(0.000)\end{array}$ & $\begin{array}{c}0.000^{* * *} \\
(0.000)\end{array}$ & $\begin{array}{c}0.001^{* * *} \\
(0.000)\end{array}$ & $\begin{array}{c}0.000 \\
(0.000)\end{array}$ & $\begin{array}{c}0.001^{* * *} \\
(0.000)\end{array}$ & $\begin{array}{c}0.001^{* * *} \\
(0.000)\end{array}$ & $\begin{array}{l}0.001^{* * *} \\
(0.000)\end{array}$ \\
\hline North I & $\begin{array}{c}-0.020^{* * *} \\
(0.000) \\
\end{array}$ & $\begin{array}{c}-0.020^{* * *} \\
(0.001) \\
\end{array}$ & $\begin{array}{c}-0.020^{* * *} \\
(0.001) \\
\end{array}$ & $\begin{array}{c}-0.119^{* * *} \\
(0.001) \\
\end{array}$ & $\begin{array}{c}-0.117^{* * *} \\
(0.003) \\
\end{array}$ & $\begin{array}{c}-0.125^{* * *} \\
(0.003)\end{array}$ & $\begin{array}{c}0.051^{* * *} \\
(0.001) \\
\end{array}$ & $\begin{array}{c}0.050^{* * *} \\
(0.003) \\
\end{array}$ & $\begin{array}{c}0.056^{* * *} \\
(0.003) \\
\end{array}$ & $\begin{array}{c}-0.002^{* * *} \\
(0.001)\end{array}$ & $\begin{array}{c}-0.003 \\
(0.002) \\
\end{array}$ & $\begin{array}{c}-0.001 \\
(0.002) \\
\end{array}$ & $\begin{array}{c}0.090^{* * *} \\
(0.001)\end{array}$ & $\begin{array}{c}0.090^{* * *} \\
(0.002) \\
\end{array}$ & $\begin{array}{l}0.091^{* * *} \\
(0.002)\end{array}$ \\
\hline Observations & 673,483 & 74,900 & 74,900 & 673,483 & 74,900 & 74,900 & 673,483 & 74,900 & 74,900 & 673,483 & 74,900 & 74,900 & 673,483 & 74,900 & 74,900 \\
\hline
\end{tabular}

\section{Robust standard errors in parentheses}

${ }^{* * *} \mathrm{p}<0.01,{ }^{* *} \mathrm{p}<0.05,{ }^{*} \mathrm{p}<0.1$

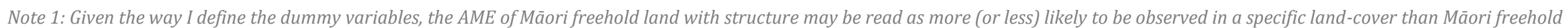
land without structure. On the other hand, the Māori freehold land coefficient may be read as a comparison between general land and Māori freehold land without structure.

Note 2: In Column 2, the sample is restricted to the spatial sample 'SG3', which I draw by selecting every third pixel in the X-and Y-direction. In Column 3, the sample is restricted to the random spatial sample 'RS' by selecting a random sample size based on SG3. 
Table 3-8 AME for land-cover transitions 1997-2012 - Māori freehold land relative to general land

\begin{tabular}{|c|c|c|c|c|}
\hline \multirow{2}{*}{$\begin{array}{c}\text { Starting land } \\
\text { cover } 1997\end{array}$} & \multirow{2}{*}{ Variable } & \multicolumn{3}{|c|}{ Outcome land cover 2012} \\
\hline & & Pasture & Forestry & Scrub \\
\hline \multirow{20}{*}{ Pasture } & \multirow[t]{2}{*}{ Māori freehold land } & $-0.008^{* * *}$ & $-0.004^{* * *}$ & $0.012^{* * *}$ \\
\hline & & $(0.002)$ & $(0.002)$ & $(0.002)$ \\
\hline & \multicolumn{4}{|l|}{ Land use capability (LUC) (base=7-8) } \\
\hline & \multirow[t]{2}{*}{ LUC classes $1-2$} & $0.039 * * *$ & $-0.032^{* * *}$ & $-0.006^{* * *}$ \\
\hline & & $(0.001)$ & $(0.001)$ & $(0.000)$ \\
\hline & \multirow[t]{2}{*}{ LUC class 3} & $0.034^{* * *}$ & $-0.028^{* * *}$ & $-0.006^{* * *}$ \\
\hline & & $(0.001)$ & $(0.001)$ & $(0.000)$ \\
\hline & \multirow[t]{2}{*}{ LUC class 4} & $0.025^{* * *}$ & $-0.021^{* * *}$ & $-0.005^{* * *}$ \\
\hline & & $(0.001)$ & $(0.001)$ & $(0.000)$ \\
\hline & \multirow{2}{*}{ LUC classes 5-6 } & $0.007^{* * *}$ & $-0.005^{* * *}$ & $-0.002^{* * *}$ \\
\hline & & $(0.001)$ & $(0.001)$ & $(0.000)$ \\
\hline & \multirow[t]{2}{*}{ Slope of the land } & $-0.001^{* * *}$ & $0.001^{* * *}$ & $0.000^{* * *}$ \\
\hline & & $(0.000)$ & $(0.000)$ & $(0.000)$ \\
\hline & \multirow[t]{2}{*}{ Distance to supermarkets } & $0.000^{*}$ & -0.000 & -0.000 \\
\hline & & $(0.000)$ & $(0.000)$ & $(0.000)$ \\
\hline & \multirow{2}{*}{ Distance to ports } & $0.001^{* * *}$ & $-0.001^{* * *}$ & $-0.000 * * *$ \\
\hline & & $(0.000)$ & $(0.000)$ & $(0.000)$ \\
\hline & \multirow[t]{2}{*}{ North Island } & $-0.013^{* * *}$ & $0.010^{* * *}$ & $0.002^{* * *}$ \\
\hline & & $(0.001)$ & $(0.000)$ & $(0.000)$ \\
\hline & Observations & 452,152 & 452,152 & 452,152 \\
\hline \multirow{20}{*}{ Forestry } & \multirow[t]{2}{*}{ Māori freehold land } & $-0.031^{* * *}$ & $0.031^{* * *}$ & \\
\hline & & $(0.002)$ & $(0.002)$ & \\
\hline & \multicolumn{4}{|c|}{ Land use capability (LUC) (base=7-8) } \\
\hline & \multirow[t]{2}{*}{ LUC classes $1-2$} & $-0.006^{*}$ & $0.006^{*}$ & \\
\hline & & $(0.003)$ & $(0.003)$ & \\
\hline & \multirow{2}{*}{ LUC class 3} & $0.029 * * *$ & $-0.029 * * *$ & \\
\hline & & $(0.003)$ & $(0.003)$ & \\
\hline & \multirow[t]{2}{*}{ LUC class 4} & $0.027^{* * *}$ & $-0.027^{* * *}$ & \\
\hline & & $(0.002)$ & $(0.002)$ & \\
\hline & LUC classes 5-6 & $0.022^{* * *}$ & $-0.022^{* * *}$ & \\
\hline & & $(0.002)$ & $(0.002)$ & \\
\hline & \multirow[t]{2}{*}{ Slope of the land } & $-0.005^{* * *}$ & $0.005^{* * *}$ & \\
\hline & & $(0.000)$ & $(0.000)$ & \\
\hline & \multirow[t]{2}{*}{ Distance to supermarkets } & $-0.008 * * *$ & $0.008^{* * *}$ & \\
\hline & & $(0.000)$ & $(0.000)$ & \\
\hline & \multirow[t]{2}{*}{ Distance to ports } & $-0.000^{* *}$ & $0.000 * *$ & \\
\hline & & $(0.000)$ & $(0.000)$ & \\
\hline & \multirow[t]{2}{*}{ North Island } & $0.020^{* * *}$ & $-0.020^{* * *}$ & \\
\hline & & $(0.001)$ & $(0.001)$ & \\
\hline & Observations & 72,729 & 72,729 & \\
\hline
\end{tabular}


Table 3-8 AME for land-cover transitions 1997-2012 - Māori freehold land relative to general land (continued)

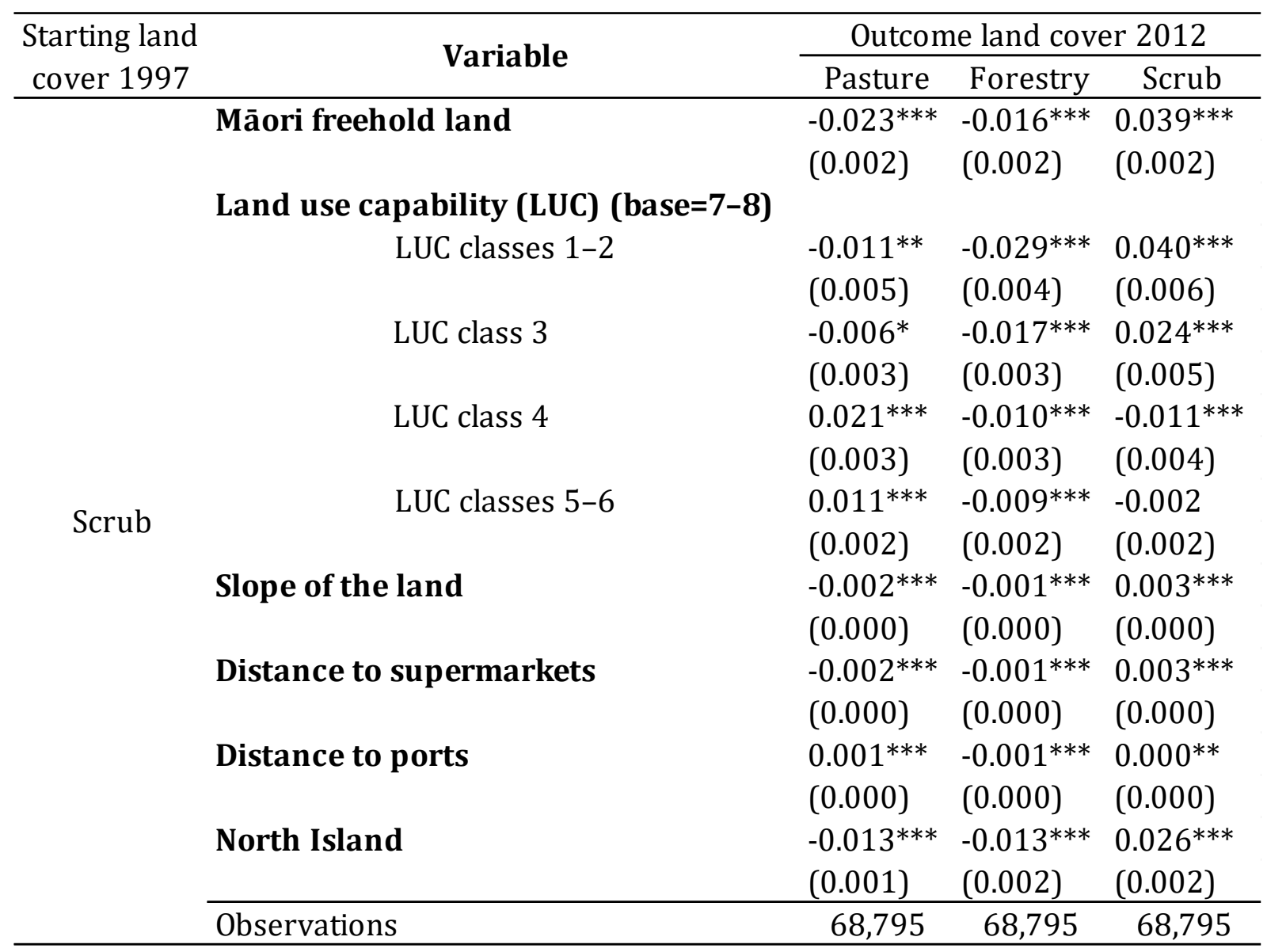

Robust standard errors in parentheses

*** $\mathrm{p}<0.01,{ }^{* *} \mathrm{p}<0.05,{ }^{*} \mathrm{p}<0.1$ 
Table 3-9 AME for land-cover transitions 1997-2012 - Māori freehold land with structure relative to Māori freehold land without structure

\begin{tabular}{|c|c|c|c|c|}
\hline \multirow{2}{*}{$\begin{array}{c}\text { Starting land } \\
\text { cover } 1997 \\
\end{array}$} & \multirow{2}{*}{ Variable } & \multicolumn{3}{|c|}{ Outcome land cover 2012} \\
\hline & & Pasture & Forestry & Scrub \\
\hline \multirow{22}{*}{ Pasture } & \multirow[t]{2}{*}{ Māori freehold land with structure } & 0.002 & $0.007^{*}$ & $-0.002^{* * *}$ \\
\hline & & $(0.002)$ & $(0.004)$ & $(0.000)$ \\
\hline & \multirow[t]{2}{*}{ Māori freehold land } & $-0.010^{* * *}$ & $-0.008^{* * *}$ & $0.018^{* * *}$ \\
\hline & & $(0.002)$ & $(0.002)$ & $(0.002)$ \\
\hline & \multicolumn{4}{|l|}{ Land use capability (LUC) (base $=7-8)$} \\
\hline & \multirow[t]{2}{*}{ LUC classes $1-2$} & $0.039 * * *$ & $-0.032^{* * *}$ & $-0.006^{* * *}$ \\
\hline & & $(0.001)$ & $(0.001)$ & $(0.000)$ \\
\hline & \multirow[t]{2}{*}{ LUC class 3} & $0.034^{* * *}$ & $-0.028 * * *$ & $-0.006^{* * *}$ \\
\hline & & $(0.001)$ & $(0.001)$ & $(0.000)$ \\
\hline & \multirow[t]{2}{*}{ LUC class 4} & $0.025^{* * *}$ & $-0.021 * * *$ & $-0.005^{* * *}$ \\
\hline & & $(0.001)$ & $(0.001)$ & $(0.000)$ \\
\hline & \multirow[t]{2}{*}{ LUC classes $5-6$} & $0.007^{* * *}$ & $-0.005^{* * *}$ & $-0.002^{* * *}$ \\
\hline & & $(0.001)$ & $(0.001)$ & $(0.000)$ \\
\hline & \multirow[t]{2}{*}{ Slope of the land } & $-0.001^{* * *}$ & $0.001^{* * *}$ & $0.000^{* * *}$ \\
\hline & & $(0.000)$ & $(0.000)$ & $(0.000)$ \\
\hline & \multirow[t]{2}{*}{ Distance to supermarkets } & 0.000 & -0.000 & -0.000 \\
\hline & & $(0.000)$ & $(0.000)$ & $(0.000)$ \\
\hline & \multirow{2}{*}{ Distance to ports } & $0.001^{* * *}$ & $-0.001^{* * *}$ & $-0.000 * * *$ \\
\hline & & $(0.000)$ & $(0.000)$ & $(0.000)$ \\
\hline & \multirow[t]{2}{*}{ North Island } & $-0.013^{* * *}$ & $0.010^{* * *}$ & $0.002^{* * *}$ \\
\hline & & $(0.001)$ & $(0.000)$ & $(0.000)$ \\
\hline & Observations & 452,152 & 452,152 & 452,152 \\
\hline \multirow{22}{*}{ Forestry } & \multirow{2}{*}{ Māori freehold land with structure } & $-0.024^{* * *}$ & $0.024^{* * *}$ & \\
\hline & & $(0.008)$ & $(0.008)$ & \\
\hline & \multirow[t]{2}{*}{ Māori freehold land } & -0.014 & 0.014 & \\
\hline & & $(0.002)$ & $(0.002)$ & \\
\hline & \multicolumn{4}{|l|}{ Land use capability (LUC) (base $=7-8)$} \\
\hline & \multirow[t]{2}{*}{ LUC classes $1-2$} & $-0.006^{*}$ & $0.006^{*}$ & \\
\hline & & $(0.003)$ & $(0.003)$ & \\
\hline & \multirow[t]{2}{*}{ LUC class 3} & $0.029^{* * *}$ & $-0.029 * * *$ & \\
\hline & & $(0.003)$ & $(0.003)$ & \\
\hline & \multirow[t]{2}{*}{ LUC class 4} & $0.027^{* * *}$ & $-0.027 * * *$ & \\
\hline & & $(0.002)$ & $(0.002)$ & \\
\hline & \multirow[t]{2}{*}{ LUC classes $5-6$} & $0.022^{* * *}$ & $-0.022^{* * *}$ & \\
\hline & & $(0.002)$ & $(0.002)$ & \\
\hline & Slope of the land & $-0.005^{* * *}$ & $0.005^{* * *}$ & \\
\hline & & $(0.000)$ & $(0.000)$ & \\
\hline & Distance to supermarkets & $-0.008^{* * *}$ & $0.008^{* * *}$ & \\
\hline & & $(0.000)$ & $(0.000)$ & \\
\hline & Distance to ports & $-0.000^{* *}$ & $0.000^{* *}$ & \\
\hline & & $(0.000)$ & $(0.000)$ & \\
\hline & North Island & $0.020^{* * *}$ & $-0.020^{* * *}$ & \\
\hline & & $(0.001)$ & $(0.001)$ & \\
\hline & Observations & 72,729 & 72,729 & \\
\hline
\end{tabular}


Table 3-9 AME for land-cover transitions 1997-2012 - Māori freehold land with structure relative to Māori freehold land without structure (continued)

\begin{tabular}{|c|c|c|c|c|}
\hline \multirow{2}{*}{$\begin{array}{c}\text { Starting land } \\
\text { cover } 1997\end{array}$} & \multirow{2}{*}{ Variable } & \multicolumn{3}{|c|}{ Outcome land cover 2012} \\
\hline & & Pasture & Forestry & Scrub \\
\hline \multirow{22}{*}{ Scrub } & \multirow[t]{2}{*}{ Māori freehold land with structure } & 0.011 & $0.037^{* *}$ & $-0.042^{* * *}$ \\
\hline & & $(0.009)$ & $(0.016)$ & $(0.015)$ \\
\hline & \multirow[t]{2}{*}{ Māori freehold land } & $-0.027^{* * *}$ & $-0.027^{* * *}$ & $0.053^{* * *}$ \\
\hline & & $(0.002)$ & $(0.002)$ & $(0.002)$ \\
\hline & \multicolumn{4}{|l|}{ Land use capability (LUC) (base=7-8) } \\
\hline & \multirow[t]{2}{*}{ LUC classes 1-2 } & $-0.011^{* *}$ & $-0.029 * * *$ & $0.040 * * *$ \\
\hline & & $(0.005)$ & $(0.004)$ & $(0.006)$ \\
\hline & \multirow[t]{2}{*}{ LUC class 3} & $-0.006^{*}$ & $-0.017^{* * *}$ & $0.023^{* * *}$ \\
\hline & & $(0.003)$ & $(0.003)$ & $(0.005)$ \\
\hline & \multirow[t]{2}{*}{ LUC class 4} & $0.021^{* * *}$ & $-0.010^{* * *}$ & $-0.012^{* * *}$ \\
\hline & & $(0.003)$ & $(0.003)$ & $(0.004)$ \\
\hline & \multirow[t]{2}{*}{ LUC classes 5-6 } & $0.011^{* * *}$ & $-0.008^{* * *}$ & -0.002 \\
\hline & & $(0.002)$ & $(0.002)$ & $(0.002)$ \\
\hline & \multirow[t]{2}{*}{ Slope of the land } & $-0.002^{* * *}$ & $-0.001^{* * *}$ & $0.003^{* * *}$ \\
\hline & & $(0.000)$ & $(0.000)$ & $(0.000)$ \\
\hline & \multirow[t]{2}{*}{ Distance to supermarkets } & $-0.002^{* * *}$ & $-0.001^{* * *}$ & $0.003^{* * *}$ \\
\hline & & $(0.000)$ & $(0.000)$ & $(0.000)$ \\
\hline & \multirow[t]{2}{*}{ Distance to ports } & $0.001^{* * *}$ & $-0.001^{* * *}$ & $0.000^{* *}$ \\
\hline & & $(0.000)$ & $(0.000)$ & $(0.000)$ \\
\hline & \multirow[t]{2}{*}{ North Island } & $-0.013^{* * *}$ & $-0.013^{* * *}$ & $0.026^{* * *}$ \\
\hline & & $(0.001)$ & $(0.002)$ & $(0.002)$ \\
\hline & Observations & 68,795 & 68,795 & 68,795 \\
\hline
\end{tabular}

Robust standard errors in parentheses

${ }^{* * *} \mathrm{p}<0.01,{ }^{* *} \mathrm{p}<0.05,{ }^{*} \mathrm{p}<0.1$

Note: Given the way I define the dummy variables, the AME of Māori freehold land with structure may be read as more (or less) likely to transition than Mãori freehold land without structure. On the other hand, the Mãori freehold land coefficient may be read as a comparison between general land and Mãori freehold land without structure. 


\section{Chapter Four. Māori land governance structures and greenhouse gas emissions}

In this chapter, I build on the econometric model of land-cover transitions presented in Chapter Three to compare the effects of transitions between forestry, pasture and scrub from 1997-2012. I use hypothetical scenarios to examine the implications of these transitions for private land, ${ }^{75}$ Māori freehold land and Māori freehold land with structure in terms of both 'carbon dioxide equivalent' $\left(\mathrm{CO}_{2} \mathrm{eq}\right)$, and 'warming equivalent' $\left(\mathrm{CO}_{2}^{*} \mathrm{we}\right)$.

As I have discussed in previous chapters, Māori communities are principally interested in whenua or land due to cultural and social imperatives, but also as a sustainable economic base for themselves and future generations. During fieldwork experience I learned that board members are interested in business that provides sustainable dividends for landowners, and supports responsible social and cultural relationships with the land and the people. Additionally, environmental compliances can intertwine with cultural goals. A decision to invest in riparian planting to protect a water body can be motivated by a legal requirement, for example, but also by concerns to fulfil the responsibilities associated with Māori being kaitiaki (stewards) of the land.

The different considerations that may be taken into account for land utilisation decisions motivate questions about how Aotearoa New Zealand would be different if the land were used following the patterns of land-cover transitions modelled in Chapter Three. I concentrate my analysis on transitions from pasture to forestry, pasture to scrub and forestry to pasture, because of the robustness of the underlying coefficients in the econometric analysis. Returning to the overarching question of my thesis, in this chapter I focus on the implications Māori land governance structures have for landcover changes and hence greenhouse gas (GHG) emissions.

To motivate discussion, I consider hypothetical situations and simulate land-cover transitions in hectares and the implications these have for GHG emissions. The hypothetical situations are based on two central questions: what would the implications be if private land was utilised in the same way as Māori freehold land with structure?

\footnotetext{
${ }^{75}$ As I discuss in footnote 43, private land is the opposite of Crown land.
} 
What would the implications be if all Māori freehold land was utilised in the same way as Māori freehold land with structure?

For the simulations, I defined factual scenarios that provide a basis for comparison with counterfactual scenarios (or hypothetical situations). I considered two samples: private land and Māori freehold land. Private land includes general land and Māori freehold land. The simulations are an academic attempt to illustrate outcomes associated with decisions on land utilisation that might be driven by several imperatives. I am not attempting to suggest changes in the land tenure system or question decisions made. The motivation behind simulating land-cover transitions in hectares, is to enrich the debate about drivers for land use and the implications of these transitions in terms of GHG emissions.

My results show that if private land was utilised as Māori freehold land with structure is, there would be less land transitioning from pasture into forestry, whereas the area in scrub would expand. The results also suggest that Māori land governance structures would retain the land in forestry. The overall change in $\mathrm{CO}_{2} \mathrm{eq}$, associated with these three land-cover transitions, was 6.3 million $\mathrm{tCO}_{2} \mathrm{eq}$ sequestered. Māori land governance structures would hypothetically increase the overall sequestration in terms of $\mathrm{CO}_{2} \mathrm{eq}$ by $27 \%$. Additionally, for the GHGs emissions implications, the results suggest that the current way of counting GHGs leads to a much lower estimate of the contribution in reductions to the impact of warming.

In terms of Māori freehold land, the results suggest that Māori land governance structures would increase the allocation of land into forestry, but would limit land allocation into scrub. Regarding transitions from forestry to pasture, the simulation results show that Māori land governance structures would keep Māori freehold land in forestry, while not having a structure in place would double the area that made this transition. In terms of GHGs, the results show 325,000 $\mathrm{tCO}_{2}$ eq sequestered. The current metric was only $54 \%$ of the contribution defined in terms of warming over 100 years. The results also suggest that Māori land governance structures would be associated with higher levels of sequestration.

The remainder of the chapter is structured as follows. Section 1 presents a brief discussion about the different metrics to calculate GHG emissions, and their relationship to warming. Section 2 presents the methodology used for calculating the factual and counterfactual scenarios. Section 3 presents the results. Section 4 concludes the chapter. 


\section{Greenhouse gases emissions: metrics}

I examine the implications of three land-cover transitions for different hypothetical scenarios in terms of GHG emissions. Before describing the methodology used for estimations, I briefly describe what GHGs are and two different emission metrics that can be used to compare the climate effects of emissions of a range of gases.

The Intergovernmental Panel on Climate Change (IPCC) defines GHGs as gases in the atmosphere (such as carbon dioxide $-\mathrm{CO}_{2}$, methane $-\mathrm{CH}_{4}$, and nitrous oxide $-\mathrm{N}_{2} \mathrm{O}$ ) that can trap heat in the atmosphere because of the absorption of infrared radiation. The direct radiative effects of the gases are compounded via interaction with feedbacks in the climate system, most notably the joint water vapour and lapse rate feedback, cloud feedbacks, and the albedo feedback (Held \& Soden, 2006). This is commonly known as the 'greenhouse effect', and human activity has exacerbated this effect, causing global warming.

Each gas has a different atmospheric lifetime. ${ }^{76} \mathrm{CO}_{2}$ and $\mathrm{N}_{2} \mathrm{O}$ are long-lived climate pollutants (LLCP) that accumulate in the atmosphere. ${ }^{77}$ Conversely, $\mathrm{CH}_{4}$ is a short-lived climate pollutant (SLCP) with a lifetime of approximately 12 years; thus, the greater part of the warming effect of current emissions occurs within the following two decades (Allen, 2015; New Zealand Productivity Commission, 2018). However, as Allen (2015) states, "the impact of methane is higher still: a tonne of methane has almost 70 times more impact than a tonne of $\mathrm{CO}_{2}$ on warming over the ensuing 20 years" (p. 11).

The word 'metric' is used for numerical comparisons of the climate effects of emissions of different GHGs. The global warming potential (GWP) is a standard metric for comparing, over a hundred-year timescale, the cumulative effect on warming of emitting one tonne of any GHG relative to emit one tonne of carbon dioxide $\left(\mathrm{tCO}_{2}\right)$. In other words, this metric compares the effects of methane, or any other non- $\mathrm{CO}_{2}$ gases and carbon dioxide, by calculating their carbon dioxide equivalence. Although the GWP is the most commonly used metric, it has long been criticised by climate scientists (e.g. Shine, 2009) because it fails to capture the temperature effects of a time-series of gases

\footnotetext{
76 Pierrehumbert (2014) defines atmospheric lifetime as "the characteristic time during which a substance added to the atmosphere remains in the atmosphere" (p. 342).

77 The main sources of $\mathrm{CO}_{2}$ are the combustion of fossil fuels, cement production and deforestation, whereas $\mathrm{N}_{2} \mathrm{O}$ has a lifetime of about 120 years and is mainly generated from artificial fertiliser use in agriculture.
} 
(Allen, 2015; Allen et al., 2018). Therefore, a newly-proposed metric, GWP*, suggests a different approach which relates cumulative $\mathrm{CO}_{2}$ emissions to date with the current rate of emission of short-lived climate pollutants, as an attempt to measure the impact of different gases on global temperature (or warming equivalent) (Allen et al., 2018).

In Aotearoa New Zealand, the agricultural sector is the largest source of emissions, compromising nearly half of total emissions. In contrast, forestry is the most significant sink of emissions, playing a critical role in meeting Aotearoa New Zealand's commitment to reducing global emissions. In this regard, in 2012, Aotearoa New Zealand's net removal from the land use, land-use change and forestry (LULUCF) sector was 25,589 kilotonnes of carbon dioxide equivalent $\left(\mathrm{ktCO}_{2} \mathrm{eq}\right)$, while the gross emissions from agriculture reached $39,222 \mathrm{ktCO}_{2} \mathrm{eq}$, with methane representing $75.3 \%$ of total emissions. ${ }^{78}$ Aotearoa New Zealand's distinctive emissions profile prompts interest in, and suggests the urgency of mitigating short-lived gas pollutants (New Zealand Productivity Commission, 2018).

In summary, each GHG has a different atmospheric lifetime. The short-lived climate pollutant associated with the agriculture sector is methane $\left(\mathrm{CH}_{4}\right)$ derived from livestock digestive systems and manure. The long-lived climate pollutants associated with the agriculture and LULUCF sectors are carbon dioxide $\left(\mathrm{CO}_{2}\right)$ from deforestation and nitrous oxide $\left(\mathrm{N}_{2} \mathrm{O}\right)$ from fertilisers. In terms of the effect on warming, reducing the stock of LLCPs is critical and the most important mitigation action, because the stock persists in the atmosphere even after emissions cease, meaning that warming does not stop until emissions reach (net) zero. By contrast, the warming implied by a flow of $\mathrm{CH}_{4}$ follows the emissions, so if the flow declines, so does associated warming. Furthermore, per kilogram, reductions in emissions of this short-lived gas can only influence peak warming if reductions in the stock of long-lived gases also cease (Bowerman et al., 2013; Pierrehumbert, 2014).

As shown in Figure 4-1 (below), transitions from pasture into forestry (or scrub) reduce warming (blue arrow). Sequestration of $\mathrm{CO}_{2}$ (LLCP 1 ) rises due to afforestation or

\footnotetext{
${ }^{78}$ Note that I use the emissions and sink from 2012 to provide a reference point with my data analysis, which covers the period 1997-2012. In 2012, the gross emissions from agriculture were distributed as $75.3 \%$ of methane from livestock digestive systems and manure, the main gas emitted. This was followed by $21.7 \%$ of nitrous oxide from fertiliser and the $3 \%$ remainder of carbon dioxide (Ministry for the Environment, 2019a, 2019b).
} 
reforestation, whilst emissions of $\mathrm{CH}_{4}(\mathrm{SLCP})$ and $\mathrm{N}_{2} \mathrm{O}\left(\mathrm{LLCP}_{2}\right)$ cease due to cow culling and decreased use of fertilisers, respectively. Transitions from forestry into pasture increase warming (red arrow) because $\mathrm{CO}_{2}$ is released due to deforestation, $\mathrm{CH}_{4}$ emissions rise with increased livestock and $\mathrm{N}_{2} \mathrm{O}$ emissions rise alongside fertiliser use.

The considerations regarding different emission metrics, discussed in this section, motivate analysis of the implications of three land-cover transitions for general land, Māori freehold land and Māori freehold land with structure, in terms of both $\mathrm{CO}_{2} \mathrm{eq}$, and $\mathrm{CO}_{2}^{*}$ we.

Figure 4-1 Long- and short-lived climate polluters and land-cover transitions

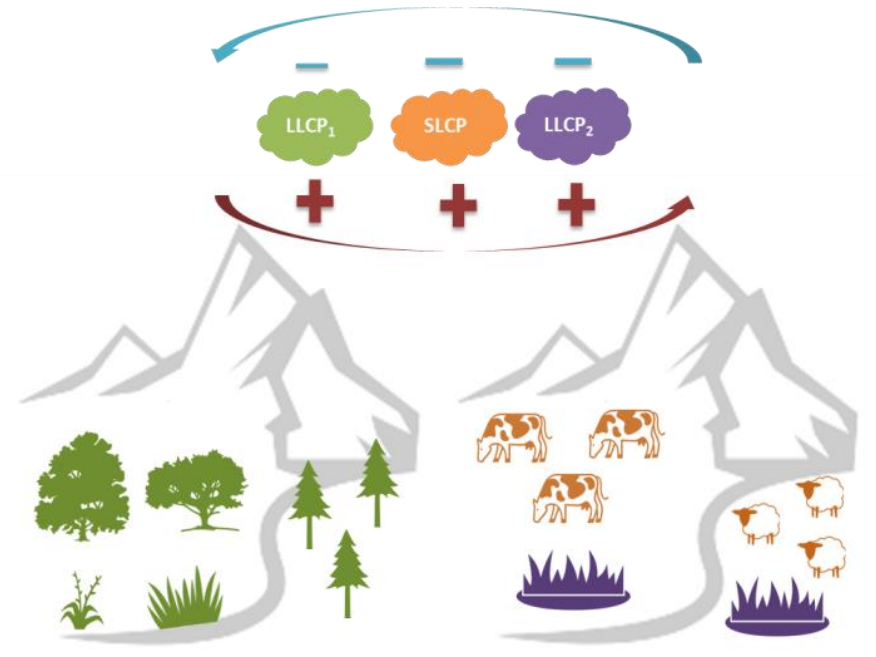

\section{Simulations under hypothetical scenarios: methodology}

This section presents the methodology used for simulating land-cover transitions in hectares and implications in terms of GHG emissions under different scenarios. The simulations build on the econometric analysis presented in Chapter Three to study the transition period from 1997 to 2012. I concentrate on three transitions: pasture to forestry, pasture to scrub and forestry to pasture. I do so because the results from the econometric analysis are robust; that is, the underlying coefficients are significant. I attempt to calculate emissions of land-cover in 2012 relative to what emissions would have been if land remained in the land-cover observed in 1997.

I start the section describing the factual and counterfactual scenarios used for the simulations. Next, I describe how I estimate the transitions in hectares, and describe the emissions or sequestration factors for estimating emissions in terms of carbon dioxide 
equivalent, followed by an estimation of emissions in terms of warming. Finally, I compare the results associated with both metrics.

\subsection{Factual and counterfactual scenarios}

Two hypothetical situations are based on two central questions. The first is to ask what the implications would be if private land was utilised in the same way as Māori freehold land with structure. The second, ask what the implications would be if all Māori freehold land was utilised in the same way as Māori freehold land with structure. Table 4-1 (below) shows the scenarios analysed.

Table 4-1 Description of scenarios for simulations

\begin{tabular}{|c|c|c|}
\hline Scenarios & Sample & Assumption \\
\hline Scenario Factual 1 & Private land & Actual observed values \\
\hline Scenario $1 \mathbf{a}^{1}$ & Private land & All private land was general land \\
\hline Scenario $\mathbf{1 b}^{1}$ & Private land & All private land was Māori freehold land \\
\hline Scenario $1 c^{2}$ & Private land & All private land was Māori freehold land with structure \\
\hline Scenario Factual 2 & Māori freehold land & Actual observed values \\
\hline Scenario $2 \mathbf{a}^{2}$ & Māori freehold land & $\begin{array}{l}\text { All Māori freehold land was Māori freehold land without } \\
\text { structure }\end{array}$ \\
\hline Scenario $2 \mathbf{b}^{2}$ & Māori freehold land & $\begin{array}{l}\text { All Māori freehold land was Māori freehold land with } \\
\text { structure }\end{array}$ \\
\hline
\end{tabular}

Note 1: This scenario is based on the coefficient estimates calculated and shown in Table A3-1 in Appendix C. Note 2: This scenario is based on the coefficient estimates calculated and shown in Table A3-2 in Appendix C.

I use two factual scenarios that provide a basis for comparison with counterfactual scenarios. Each factual scenario has a specific sample. Scenario Factual 1 is based on the sample 'private land, which includes general land and Māori freehold land'. Scenario Factual 2 is based on the sample 'Māori freehold land'. The two factual scenarios show the actual values observed (such as land status or land characteristics) on each sample, while the counterfactual scenarios vary depending on the assumption. ${ }^{79}$ Therefore, the

\footnotetext{
${ }^{79}$ In a logic model the average of probability among actual observations in the data is the same as the average of the responses, meaning that the average of probabilities estimated in Scenario
} 
results from Scenarios 1a - 1c can only be compared with Scenario Factual 1, whereas Scenarios 2a and 2b can only be compared with Scenario Factual 2.

\subsection{Land-cover transitions in hectares}

For calculating the land-cover transitions in hectares by scenarios, I used the results of the econometric analysis on land-cover transitions from 1997 to 2012 discussed in Chapter Three. Using the coefficient estimates, for each of the scenarios described in Table 4-1 (above), I calculated the 'average predicted probability' of transition from 1997 to 2012 (hereafter probability estimates). Table A4-1, in Appendix D, shows the probability estimates by scenarios. Next, I used the probability estimates to calculate the number of pixels that would made a transition. As an example, I multiplied pixels in pasture in 1997 by probability estimates of changing to forestry in 2012. Later, I converted pixels into hectares. ${ }^{80}$ Table A4-2, in Appendix D, shows the land-cover transitions in hectares by scenarios.

\subsection{Emissions estimated from land-cover transitions}

I estimated GHG emissions using two metrics: carbon equivalent and warming equivalent. I used emissions factors for pasture and sequestration factors for scrub and forestry. ${ }^{81}$ For the carbon equivalent, I used an emissions factor for pasture, in terms of $\mathrm{CO}_{2}$ eq using GWP100. For warming equivalent, I separated the emissions factor from pasture by $\mathrm{CH}_{4}$ and long-lived gases.

There are two considerations in the analysis due to data constraints. First, I do not have information on the exact year of transition, so I only calculated emissions for each hectare change in total area, per year, rather than throughout the simulation period. Second, I do not have information about the age of the forest or the scrub, nor the type of

Factual 1 and Scenario Factual 2 are the same as the land shares reported in the transition matrix shown in Table 3-4 on page 104.

${ }^{80}$ As I discuss in Section 2 in Chapter Three, the unit of observation from the New Zealand Private Land (NZPRL) dataset is a pixel of 25 hectares.

81 Timar and Kerr (2014) define that "an emission factor measures the amount of greenhouse gas emissions, in carbon dioxide equivalent, that is associated with performing a unit of a specific activity" (p. 2). 
plant species. So, I had to make some general assumptions for calculating sequestrations, which I discuss in the following section.

\subsubsection{Emissions and sequestration factors}

Based on calculations made for Land Use Rural New Zealand (LURNZ) ${ }^{82}$, I assume that the average annual accumulation sequestration, per hectare of land that transitioned into forestry between 1997 and 2012, was 31.83 tCO2 per hectare per year (Timar, 2018a; Dorner et al., 2018). This sequestration factor for forestry was built under the assumption that the average level of carbon stock is based on a 28-year rotation, factoring in harvested wood products. ${ }^{83}$ If land transitioned out of forestry during the simulation period, $31.83 \mathrm{tCO}_{2}$ per hectare per year, is assumed to be released.

I assume that sequestration on land that transitioned into scrub between 1997 and 2012 was $6.5 \mathrm{tCO}_{2}$ per hectare per year. The annual sequestration factor of scrub is from Carver and Kerr (2017), who calculated the average sequestration of native forest per year over a 50-year period. Sequestration from scrub land varies across locations. Moreover, data on spatially explicit potential for native regeneration and sequestration rates is not available. Therefore, I assume that all scrub land is suitable for regenerating native forests.

Note that I use sequestration factors for forestry and scrub to explain 'new forest' or loss of exotic forest. I use the same annual factor for both, but in real time. The first case

\footnotetext{
82 See footnote 52 on page 77, for further details about LURNZ.

${ }^{83}$ For simplicity, I use the average annual carbon stock accumulation for forestry. However, it is worth clarifying that, in Aotearoa New Zealand, as a result of the changes introduced by the Climate Change Response (Emissions Trading Reform) Amendment Act 2019 (hereafter ETR Act), after 2022 two accounting methods will apply for calculating the carbon stock in post-1989 forests registered in the NZ ETS: carbon stock-change and averaging accounting. These methods differ primarily because participants using carbon stock-change accounting calculate carbon sequestered as their forest grows (Ministry for Primary Industries, 2019; Te Uru Rākau, 2019a), whereas participants using averaging accounting calculate carbon sequestered as their forest grows up to a determined average level of long-term carbon storage (Te Uru Rākau, 2019b). The choice between methods is dictated by the year the forest is registered in the NZ ETS. Cortés Acosta, Grimes and Leining (forthcoming) discuss the most recent changes in relation to forestry options under the ETR Act.
} 
is a flow of sequestration for a limited period of time; while, in the second case, it is a loss of stock.

As mentioned, I use two different emissions factors for pasture: 'carbon dioxide equivalent' and 'warming equivalent'. In the next subsections, I provide further details.

\section{Emissions factor for pasture in terms of carbon dioxide equivalent}

I calculate the emissions factor for pasture in terms of carbon dioxide equivalent, per year, based on GHG emissions assessed with the LURNZ model for sheep and beef and dairy (Timar, 2018b; Timar \& Kerr, 2014). Given the data constraints, I estimate the average emissions factor of pasture by multiplying the emissions per hectare, in 2012, of dairy, and sheep and beef, with their corresponding shares of New Zealand's area in these uses. Therefore, the average emissions from land that transitioned into pasture between 1997 and 2012 were 3.35 tCO2eq per hectare per year.

\section{Emissions factor for pasture in terms of warming}

For calculating the emissions factor for pasture in terms of warming, I also use GHG emissions estimated with the LURNZ model for sheep and beef and dairy (Timar, 2018 b; Timar \& Kerr, 2014). Given the data constraints, I estimate the average emissions factor of pasture by separating the emissions per hectare between stock gas $\mathrm{CO}_{2} \mathrm{eq}$ and flow gas $\mathrm{CH}_{4}$. I assume that $20 \%$ of land in pasture is in dairy activities, whereas $80 \%$ is in sheep and beef activity. I assume a composition of emissions for dairy farms is a gas mix of $74 \%$ methane and $26 \%$ of nitrous oxide, while sheep and beef farms have a gas mix of $87 \%$ methane and $13 \%$ nitrous oxide. 84 Therefore, the emissions factor of stock gas $\mathrm{CO}_{2}$ eq on land that transitioned into pasture between 1997 and 2012 was 2.09 $\mathrm{tCO}_{2} \mathrm{eq}$ per hectare per year.

Following Allen et al. (2018), the emissions factor of the flow gas $\mathrm{CH}_{4}$ is calculated as the change in the emissions in pasture from 1997 to 2012 multiplied by a GWP* multiplier, which is equal to $\frac{G W P \times H}{\Delta T} .85$ The emissions factor of flow gas $\mathrm{CH}_{4}$ on land that

\footnotetext{
84 The assumed proportion of methane and nitrous oxide is based on informal conversations and calculations from Reisinger and Clark (2016), however these numbers have not been peerreviewed.

85 In this example, GWP is equal to $28, \Delta T$ is a time-interval equal to 15 years (because the analysis is from 1997 to 2012) and $\mathrm{H}$ is a time-horizon equal to 100 years.
} 
transitioned into pasture between 1997 and 2012 is $0.10 \mathrm{tCH}_{4}$ per hectare per year, and the GWP* multiplier is 186.67. The Allen et al. (2018) approach has been refined in Cain et al. (2019) but is accurate enough to estimate the relative contributions to warming over a 100-year period from the different transitions.

\subsubsection{Emissions estimates in terms of carbon dioxide equivalent}

I estimate a reduction in GHG emissions for switching from pasture into forest as the net effect of reducing emissions from land going out of pasture and the increased sequestration from new forestry, in this case afforestation with exotic forest. 86

$$
G H G_{\mathrm{CO}_{2} e q_{\mathrm{p} 97-\mathrm{f} 12}}=\left(\text { Area }_{\mathrm{p} 97} \times \operatorname{Prob}_{\mathrm{p} 97-\mathrm{f} 12}\right) \times\left(\overline{S F}^{\text {forestry }}-\overline{\mathrm{EF}}^{\text {pasture }}\right)
$$

Similar to the previous calculation, I estimate a reduction in GHG emissions for moving into scrub as the net effect of reducing emissions from land going out of pasture and the increased sequestration from a new forest. I assume this transition might involve some sort of active decision to remove livestock and allow regeneration. I do not account for changes in soil carbon storage. ${ }^{87}$

$$
G H G_{\mathrm{CO}_{2} e q} \mathrm{p} 97-\mathrm{s} 12=\left(\text { Area }_{\mathrm{p} 97} \times \operatorname{Prob}_{\mathrm{p} 97-\mathrm{s} 12}\right) \times\left(\overline{S F}^{\text {scrub }}-\overline{E F}^{\text {pasture }}\right)
$$

I estimate positive GHG emissions for switching from forestry into pasture, as a result of deforestation, because the sequestration that would have otherwise occurred every year is lost.

$$
G H G_{\mathrm{CO}_{2} e q_{\mathrm{f} 97-\mathrm{p} 12}}=\left(\text { Area }_{\mathrm{f} 97} \times \operatorname{Prob}_{\mathrm{f} 97-\mathrm{p} 12}\right) \times\left(\overline{E F}^{\text {pasture }}-\overline{\mathrm{SF}}^{\text {forestry }}\right)
$$

Each term from Equation [4-1], Equation [4-2] and Equation [4-3] is explained in Table 4-2 on page 126.

\footnotetext{
86 Dorner et al. (2019) report that there is loss of soil carbon as land moves out of pasture; this process lasts 20 years, nearly as long as the positive sequestration. As the authors highlight, loss of soil carbon could lead to changes in my results. Transitions from low-producing grassland to forest lose 2.5 to $2.6 \mathrm{tCO}_{2}$ per hectare per year, while changes from high producing grassland to forest lose 2.4 to $2.5 \mathrm{tCO}_{2}$ per hectare per year.

$87 \mathrm{~A}$ caveat of the analysis is that I cannot see whether the regeneration is with native trees or different species, so I assume it is a process of regeneration with native species.
} 


\subsubsection{Emissions estimates in terms of warming}

The difference with the previous GHG emission estimates is in the emissions factor for pasture. For calculating emissions in terms of warming equivalent ( $\left.\mathrm{CO}_{2}^{*} \mathrm{we}\right)$, I separate emissions from pasture between stock gas $\mathrm{CO}_{2} \mathrm{eq}$ and flow gas $\mathrm{CH}_{4}$. Again, I estimate a reduction in warming for switching from pasture into forest, due to the effect of decreasing emissions from land going out of pasture and the increased sequestration from new forestry.

$$
\widehat{G H G}_{C O_{2}^{*} w e_{\mathrm{p} 97-\mathrm{f} 12}}=\left(\text { Area }_{\mathrm{p} 97} \times \operatorname{Prob}_{\mathrm{p} 97-\mathrm{f} 12}\right) \times\left(\overline{S F}^{\text {forestry }}-\mathrm{EF}_{S}^{p}-\Delta \mathrm{EF}_{f}^{p} \times \mathrm{M}^{*}\right)
$$

Similar to the previous calculation, I estimate a decrease in warming impact due to transitions from pasture into scrub. Again, I assume increased sequestration from a regenerated forest and I do not account for changes in soil carbon storage.

$$
\widehat{G H G}_{C O_{2}^{*} w e_{\mathrm{p} 97-\mathrm{s} 12}}=\left(\operatorname{Area}_{\mathrm{p} 97} \times \operatorname{Prob}_{\mathrm{p} 97-\mathrm{s} 12}\right) \times\left(\overline{S F}^{s c r u b}-\mathrm{EF}_{s}^{p}-\Delta \mathrm{EF}_{f}^{p} \times \mathrm{M}^{*}\right)
$$

I estimate a positive impact in warming due to an increase in GHG emissions for switching from forestry into pasture.

$$
\widehat{G H G}_{C O_{2}^{*} w e_{\mathrm{f} 97-\mathrm{p} 12}}=\left(\text { Area }_{\mathrm{p} 97} \times \operatorname{Prob}_{\mathrm{f} 97-\mathrm{p} 12}\right) \times\left(\mathrm{EF}_{S}^{p}+\Delta \mathrm{EF}_{f}^{p} \times \mathrm{M}^{*}-\overline{S F}^{\text {forestry }}\right)
$$

Each term from Equation [4-4] to Equation [4-6] is explained in Table 4-2 (below). 
Table 4-2 Explanation of terms used in GHG emission estimates

\begin{tabular}{|c|c|}
\hline Term & Description \\
\hline Area $_{\text {p97 }}$ & Area in pasture in 1997 (hectares) \\
\hline Area $_{\text {f97 }}$ & Area in forestry in 1997 (hectares) \\
\hline Prob $_{\text {p9-f12 }}$ & Probability of transitions from pasture in 1997 to forestry in 2012 (\%) \\
\hline $\operatorname{Prob}_{\mathrm{p} 97-s 12}$ & Probability of transitions from pasture in 1997 to scrub in 2012 (\%) \\
\hline Prob $_{\text {f97-p12 }}$ & Probability of transitions from forestry in 1997 to pasture in 2012 (\%) \\
\hline$\overline{S F}^{\text {forestry }}$ & Sequestration factor for forestry $\left(\mathrm{tCO}_{2} \mathrm{eq}\right)$ \\
\hline$\overline{S F}^{\text {scrub }}$ & Sequestration factor for scrub $\left(\mathrm{tCO}_{2} \mathrm{eq}\right)$ \\
\hline$\overline{E F}^{\text {pasture }}$ & Emissions factor for pasture $\left(\mathrm{tCO}_{2} \mathrm{eq}\right)$ \\
\hline $\mathrm{EF}_{s}^{p}$ & Emissions factor of stock gas $\mathrm{CO}_{2-\text { we }}^{*}$ \\
\hline$\Delta \mathbf{E F}_{f}^{p}$ & Emissions factor of flow gas $\mathrm{CH}_{4}$ \\
\hline $\mathbf{M}^{*}$ & GWP* multiplier $^{*}$ \\
\hline
\end{tabular}

\section{Simulation results}

In this section, I present land-cover transitions between 1997 and 2012 (pasture to forestry, pasture to scrub and forestry to pasture) and comparisons among simulation scenarios (see Table 4-1 on page 120). I discuss the results by changes in hectares and the implications of these changes in terms of both carbon dioxide equivalent, and warming equivalent. I separate the analysis by all private land and Māori freehold land.

\subsection{Private land}

Scenario Factual 1 shows the actual changes observed in private land during the period of study. Comparing the three land-cover transitions under analysis, the largest area of transition observed was from pasture into forestry, with approximately 246,000 hectares of new exotic forest, which sequestered 8.7 million $\mathrm{tCO}_{2} \mathrm{eq}$. This is followed by transitions from forestry into pasture with an increase of approximately 80,000 hectares in pasture, representing 2.8 million $\mathrm{tCO}_{2} \mathrm{eq}$ emitted. Meanwhile, the transition of 49,000 hectares from pasture into scrub resulted in sequestration of 488,000 tCO2eq. For this 
result it was assumed that scrub was suitable for regenerating native forests. Table A4-3, in Appendix D, provides further details about the results.

Figure 4-2 Changes in hectares, by scenarios - private land

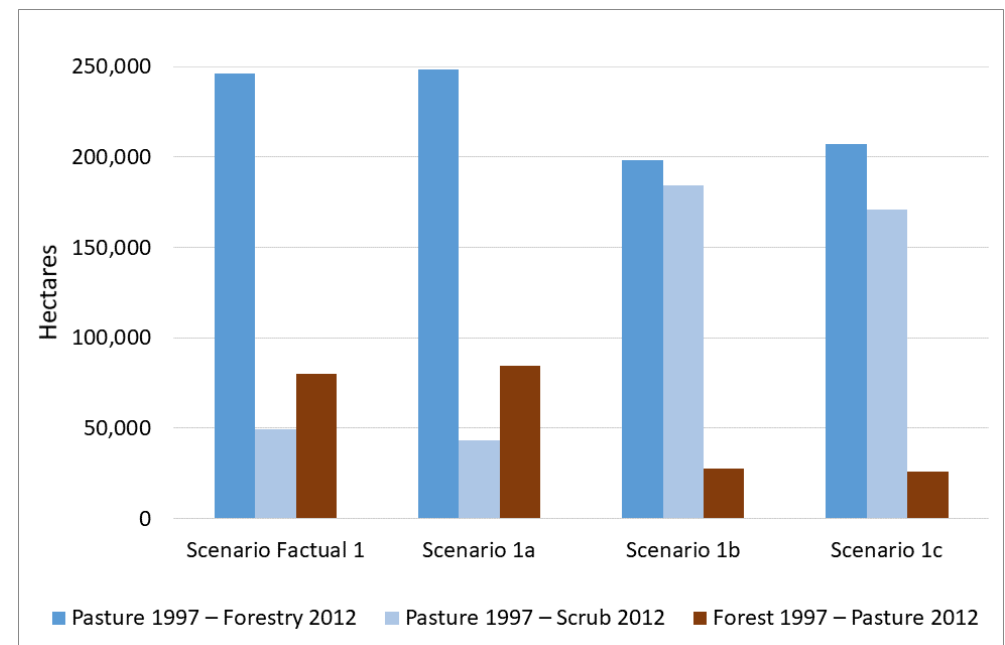

Figure 4-2 (above) shows the changes in hectares and Figure 4-3 (below) illustrates emissions or captures of $\mathrm{tCO}_{2} \mathrm{eq}$, both associated with transitions across pasture, forestry and scrub, divided by scenarios. Each of the counterfactual scenarios varies according to the assumptions summarised in Table 4-1 on page 120; specifically, under a hypothetical scenario, private land was utilised as general land (Scenario 1a), as Māori freehold land (Scenario 1b) or as Māori freehold land with structure (Scenario 1c).

Regarding the transition from pasture in 1997 to forestry in 2012, if private land was utilised as general land, an additional 2,000 hectares would have made this transition resulting in a sequestration grow by $0.9 \%$. Conversely, if private land was utilised as Māori freehold land, about 47,000 hectares of land would have remained in pasture and sequestration would be $19.4 \%$ less. These results are expected; as discussed in the conceptual framework, Section 1, in Chapter Three, Māori landowners face higher conversion costs that affect such transitions and Māori land governance structures help to reduce these costs. The results suggest that having a Māori land governance structure in place facilitates changes from pasture into forestry. Although the results from Scenario 1c still suggest that 39,000 hectares would remain in pasture, $\mathrm{tCO}_{2} \mathrm{eq}$ sequestered would fall by $15.9 \%$, relative to the sequestration observed. A possible explanation may be access to capital or reductions of decision costs. 
Figure 4-3 GHG emissions or captures, carbon dioxide equivalent, by scenarios - private land

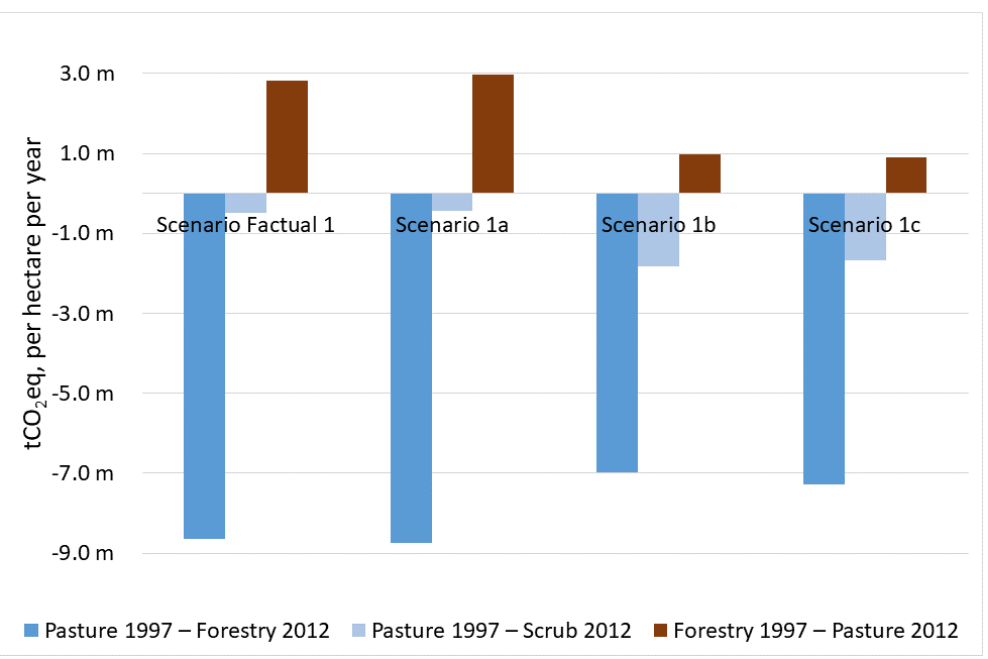

Regarding the transition from pasture in 1997 to scrub in 2012, the simulation results indicate that the area moving to scrub would be larger if private land was used as Māori freehold land (Scenario 1b) than as Māori freehold land with structure (Scenario 1c). Under Scenario 1b, an additional 135,000 hectares would be converted into scrub; this means $\mathrm{tCO}_{2}$ eq sequestered would grow by $272 \%$. Whereas, under Scenario $1 \mathrm{~b}$, the area switching to scrub would increase, but only by approximately 121,000 hectares and sequestration would grow by $244.8 \%$. In contrast, under Scenario 1a, approximately 6,000 hectares would not have made this transition; therefore, emissions would increase by $12.6 \%$. These results might be explained by the presence of amenity values, which motivate some sort of active decision to remove animals and allow regeneration. Alternatively, this may be explained by Māori landowners deciding to let the land revert to scrub. Further analysis is required to assess whether this transition is associated with an active decision or other drivers that motivate this land allocation and if this new area in scrub is the first stage for land to revert back into native forest. ${ }^{88}$

The last transition of analysis is from forestry in 1997 to pasture in 2012 . The results indicate that this transition would be influenced by land status and the presence of a structure in place. If private land was used as general land (Scenario 1a), an additional 4,000 hectares would be in pasture, meaning an increase in the emissions by $5.3 \%$. On

\footnotetext{
${ }^{88}$ Another potential explanation for the results is the presence of capital constraints or decision costs, which are higher for Māori landowners. In this case, Māori land governance structures can help to address these costs or constraints, which means that less land area would be 'abandoned'.
} 
the other hand, if all private land was used as Māori freehold land (Scenario 1b), approximately 52,000 hectares would remain in forestry and emissions would be $65.4 \%$ less. If private land was used as Māori freehold land with structure (Scenario 1c), approximately 54,000 hectares would stay in forestry and emissions would be $67.7 \%$ less. Notably, the differences in the results from Scenario $1 \mathrm{~b}$ and Scenario 1c suggest that a Māori land governance structure would keep the land in exotic forestry, but also provide potential for future discussions about the role of having Māori freehold land leased to a third party, briefly mentioned in the first two chapters.

In the following sub-sections, I discuss the implications of these transitions in terms of warming equivalent $\left(\mathrm{CO}_{2}^{*} \mathrm{we}\right)$.

\subsubsection{GHG emissions or captures in terms of warming equivalent}

Figure 4-4 (below) identifies the amount of GHG emissions in terms of warming equivalent, separating long- and short-lived climate polluters across the three landcover transitions analysed, by scenarios using the sample of private land.

Regarding transitions from pasture into forestry, over $60 \%$ of all sequestration is allocated to carbon dioxide ( $\operatorname{LLCP}_{1}$ ), while $36 \%$ is associated with reductions in methane (SLCP) and 4\% with nitrous oxide (LLCP2). Note that the same distribution is observed in transitions from forestry into pasture, but in the first, there is a reduction in emissions, while in the second there is an increase. In the case of transitions from pasture into scrub, the distribution varies to $69 \%$ less emissions of SLCP, $23 \%$ is associated with sequestration of LLCP 1 and 7\% with lower emissions of LLCP2. 
Figure 4-4 GHG emissions or captures, warming equivalent, by scenarios -private land

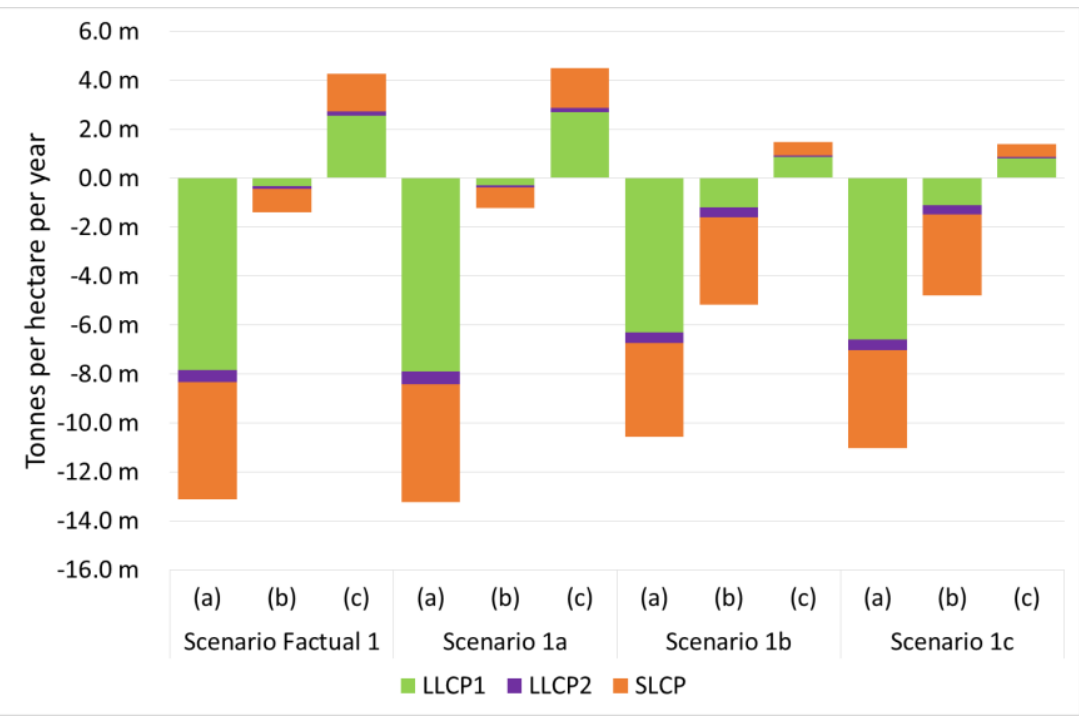

Note 1: (a) refers to the transition from pasture in 1997 to forestry in 2012, (b) refers to the transition from pasture in 1997 to scrub in 2012 and (c) refers to the transition from forestry in 1997 to pasture in 2012.

Note 2: LLCP1 refers to the long-lived climate pollutant carbon dioxide. SLCP refers to the short-lived climate pollutant methane. LLCP2 refers to the long-lived climate pollutant nitrous oxide.

The overall change in GHG emissions estimated by using both 'carbon dioxide equivalent' and 'warming equivalent' suggests that the current way of counting (i.e. carbon equivalent) produces a lower estimate of the contribution in reductions to the impact of warming over a 100-year period, as shown in Table 4-3 (below). The recorded change is only $62 \%$ of the reduction in warming (see Scenario 1 ).

Table 4-3 Emissions estimates for land-cover transitions from 1997 to 2012 -private land

\begin{tabular}{l|lll}
\hline & $\sum \mathbf{E}_{\mathrm{tCo}_{2} \mathbf{e q}}$ & $\sum \mathbf{E}_{\mathbf{t c o}_{2}^{*} \mathbf{w e}}$ & Ratio \\
\hline Scenario Factual 1 & $-6,324,784$ & $-10,229,324$ & $61.8 \%$ \\
\hline Scenario 1a & $-6,192,613$ & $-9,947,384$ & $62.3 \%$ \\
\hline Scenario 1b & $-7,819,060$ & $-14,252,511$ & $54.9 \%$ \\
\hline Scenario 1c & $-8,055,612$ & $-14,435,719$ & $55.8 \%$ \\
\hline
\end{tabular}

Note 1: To compare between the two metrics for estimating emissions, I calculated the overall emissions by adding emissions estimates of each of the land-cover transitions analysed.

Note 2: Overall change of GHG emissions in terms of carbon dioxide equivalent ( $\left.\sum E_{\mathrm{CO}_{2} \text { eq }}\right)$ and warming equivalent $\left(\sum E_{t C O_{2}^{*} w e}\right)$ 


\subsection{Māori freehold land}

In this section, I discuss the simulation results, Scenario Factual 2 being the actual changes observed in Māori freehold land between 1997 and 2012. Once again, the largest area of transition observed was from pasture into forestry, with approximately 9,000 hectares of new exotic forest and 317,000 $\mathrm{tCO}_{2}$ sequestered. This is followed by approximately 8,000 more hectares of scrub resulting in 80,000 $\mathrm{tCO}_{2}$ sequestered, and about 2,000 hectares of new pasture, resulting in 317,000 $\mathrm{tCO}_{2}$ emitted. Table A4-4, in Appendix D, provides detailed information on the results.

Figure 4-5 Changes in hectares, by scenarios - Māori freehold land

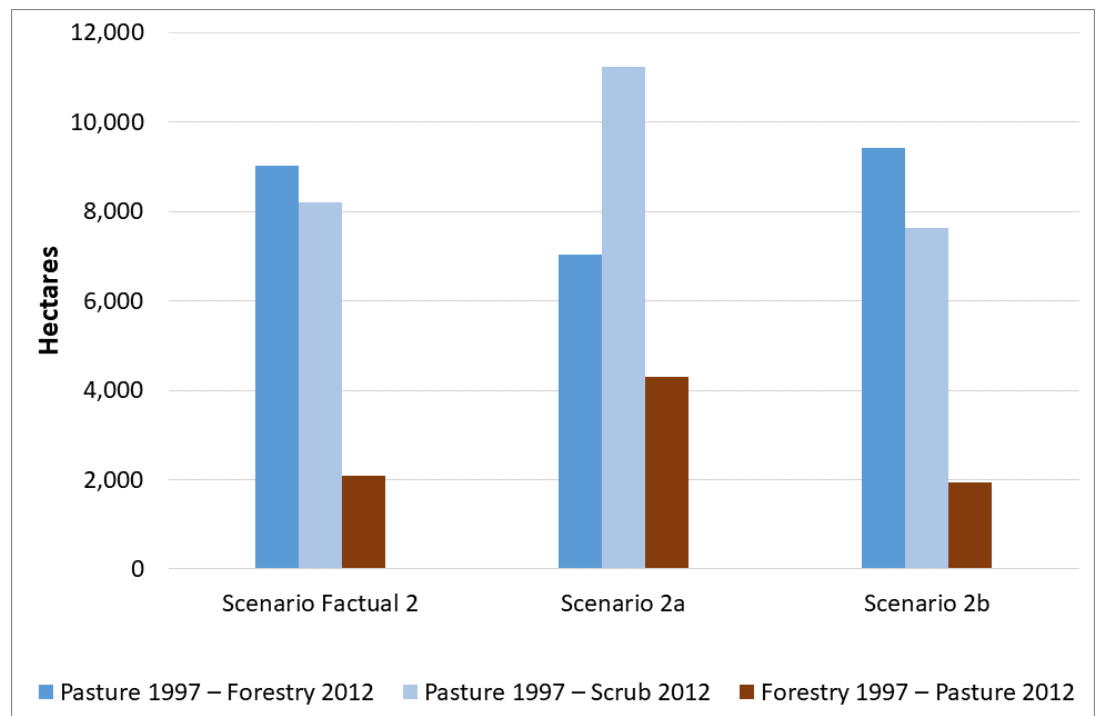

The simulation results for Māori freehold land in hectares and the emissions or captures of $\mathrm{tCO}_{2} \mathrm{eq}$ are illustrated in Figure 4-5 (above) and Figure 4-6 (below), respectively. As mentioned, simulations were based on hypothetical situations (see Table 4-1 on page 120), assuming that all Māori freehold land was used as Māori freehold land without structure (Scenario 2a) or as Māori freehold land with structure (Scenario 2b). 
Figure 4-6 GHG emissions or captures, carbon dioxide equivalent, by scenarios - Māori freehold land

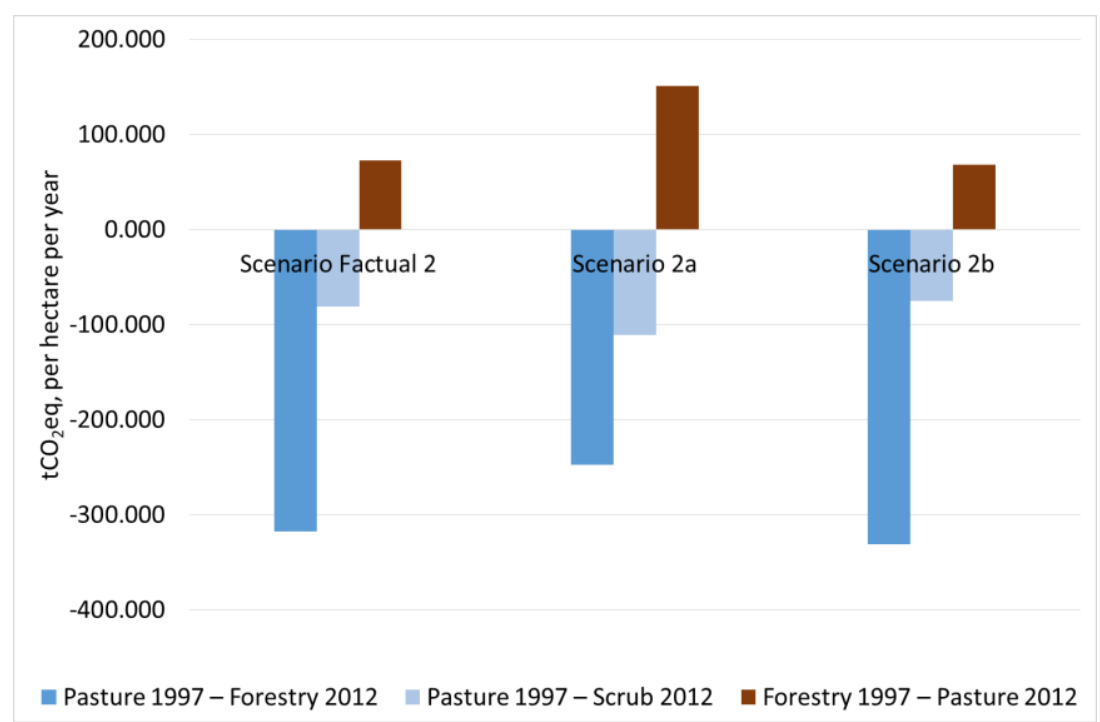

For the transition from pasture in 1997 to forestry in 2012, under Scenario 2a, approximately 2,000 hectares would stay in pasture (and GHG emissions would grow by $22 \%$ ), but under Scenario $2 \mathrm{~b}$ there would be approximately 400 hectares more of new exotic forest (and GHG emissions would decrease by 4.3\%). Although the area in new exotic forest is small, these results suggest that Māori land governance structures would increase the land allocation into this land cover.

In terms of transitions from pasture in 1997 to scrub in 2012, under Scenario 2a, approximately 3,000 hectares would have made this transition (and GHG emissions would decrease by $37 \%$ ), but under Scenario 2 b, approximately 600 hectares would remain in pasture (and GHG emissions would increase by 7.1\%). As discussed in the conceptual framework, Section 1, in Chapter Three, amenity values may motivate transitions to scrub, in which case scrub can be seen as the first stage for land to develop back into native forest. However, decisions from a governance structure can also be driven by the economic interests of landowners.

Regarding transitions from forestry in 1997 to pasture in 2012, consistent with former results, the simulations show that Māori land governance structures would keep Māori freehold land in exotic forest, which means that GHG emissions would be reduced by $7 \%$. In contrast, not having a structure in place would double the number of actual hectares that would make the change from forestry into pasture (and GHG emissions would increase by 107\%). Interestingly, if landowners prefer to have their land in 
forestry activities, then Māori land governance structures play a critical role in decisions on land utilisation.

\subsubsection{GHG emissions or captures in terms of warming equivalent}

Figure 4-7 (below) identifies the amount of GHG emissions in terms of warming equivalent, separating long- and short-lived climate polluters, across the three landcover transitions analysed, by the scenario of only Māori freehold land.

As in earlier discussion, $60 \%$ of all sequestration is allocated to carbon dioxide (LLCP 1 ), 36\% is associated with reductions in methane (SLCP) and $4 \%$ with nitrous oxide $\left(\mathrm{LLCP}_{2}\right)$ for transitions from pasture into forestry. Note that an equal distribution is observed in transitions from forestry into pasture, but in the first there is a reduction in emissions, while in the second there is an increase. However, for transitions from pasture into scrub, the distribution is 69\% less emissions of SLCP, $23 \%$ associated with sequestration of LLCP 1 and 7\% less emissions of LLCP 2.

Figure 4-7 GHG emissions or captures, warming equivalent, by scenarios - Māori freehold land

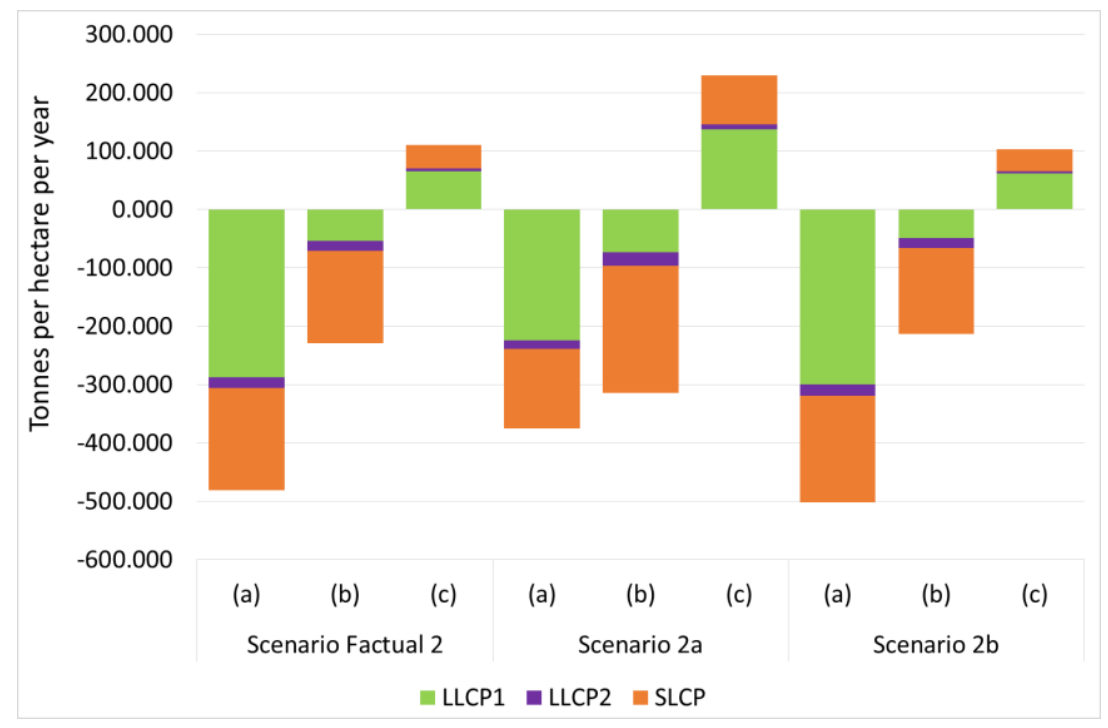

Note 1: (a) refers to the transition from pasture in 1997 to forestry in 2012, (b) refers to the transition from pasture in 1997 to scrub in 2012 and (c) refers to the transition from forestry in 1997 to pasture in 2012.

Note 2: LLCP1 refers to the long-lived climate pollutant carbon. SLCP refers to the short-lived climate pollutant methane. $L L C P_{2}$ refers to the long-lived climate pollutant nitrous oxide. 
As shown in Table 4-4 (below) the overall change in GHG emissions associated with Māori freehold land was a sequestration of 325,000 $\mathrm{tCO}_{2} \mathrm{eq}$, in which case the current metric was only $54 \%$ of the contribution defined in term of warming over 100 years.

Table 4-4 Emissions estimates for land-cover transitions from 1997 to 2012 - Māori freehold land

\begin{tabular}{l|lll}
\hline & $\sum \mathbf{E}_{\mathrm{tCO}_{2} \mathbf{e q}}$ & $\sum \mathbf{E}_{\mathbf{t c o}_{2}^{*} \text { we }}$ & Ratio \\
\hline Scenario Factual 2 & $-325,324$ & $-599,852$ & $54.2 \%$ \\
\hline Scenario 2a & $-207,012$ & $-460,129$ & $45.0 \%$ \\
\hline Scenario 2b & $-338,086$ & $-611,615$ & $55.3 \%$
\end{tabular}

Note 1: To compare between the two metrics for estimating emissions, I calculated the overall emissions by adding emissions estimates of each of the land-cover transitions analysed.

Note 2: Overall change of $\mathrm{CO}_{2}$ eq in terms of carbon dioxide equivalent $\left(\sum E_{\mathrm{CO}_{2} \text { eq }}\right)$ and warming equivalent $\left(\sum \boldsymbol{E}_{\boldsymbol{t}} \boldsymbol{O}_{2}^{*}\right.$ we $)$.

\section{Conclusions}

In this chapter, I have focused on the relationship between Māori land governance structures, three land-cover transitions between 1997 and 2012 (pasture to forestry, pasture to scrub and forestry to pasture) and their implications, in terms of GHG emissions.

I considered what may have happened if private land had been utilised in the same way as Māori freehold land with structure. Relative to what was observed, the simulation results suggest that scrub areas would have increased and new forest area would have been decreased. However, the most interesting results are when comparing to the hypothetical scenario of private land being utilised as Māori freehold land. In this hypothetical scenario, although the area of new forestry would be less than the observed area, the decrease is lower than if the land had been used as Māori freehold land. Additionally, the simulation results suggest that governance structures would keep more land in exotic forestry and the area switching to scrub would expand, but in a smaller proportion than for Māori freehold land.

I also considered what may have happened if all Māori freehold land had a governance structure. Results suggest that governance structures may have reduced the allocation of land into scrub, but might not have prevented transitions from occurring. 
This result could be explained by either the presence of amenity values or more access to capital. This reduced movement into scrub could reflect two factors: one, that governance structures might better be able to take amenity values of scrub into account and decide to allow land to regenerate toward native forest; but two, governance structures have more access to capital so might be more tempted to invest in forestry. Importantly, further information about landowners' aspirations is necessary to distinguish between these two explanations. Moreover, results suggest that forestry areas would have increased, because there would have been more new forestry and less loss of forest transitioning into pasture. Interestingly, not having a Māori land governance structure in place would double the area of land transitioning out of forestry. A question prompted by these results concerns whether the pastoral activities associated with this transition are more likely to be in dairy or sheep and beef. Furthermore, it would be interesting to explore whether this transition might be led by a land lease.

I also considered the implications these differences would have had for GHG emissions or captures. The two counterfactual scenarios associated with using the land as Māori freehold land with structure would represent more $\mathrm{tCO}_{2}$ sequestered than factual scenarios. Although my research does not aim to explore incentives for allocating land into regenerative native forest, the positive implications for the long-term storage of scrub as a first stage of land regeneration into native forest are notable. Having more detailed information about the type of tree species on the land would help to identify whether the land moving into scrub is suitable for regenerating native forests (or even mixed species). For a general context, Harmsworth (2018) estimates that 33.3\% of Māori freehold land is in indigenous forest, $30.7 \%$ is pastoral or grassland, $14.6 \%$ is in scrub and shrubland and $13.2 \%$ in planted exotic forest. ${ }^{89}$ What Māori do with their land in scrub and forest may have implications for the long-term GHG emissions of the country and its transition to a low-emissions economy (New Zealand Productivity Commission, 2018).

My results also suggest that the current way of counting emissions leads to a much lower estimate of the impact of the contribution of Māori land governance structures relative to a metric that estimates its impact on cumulative warming over 100 years.

${ }^{89}$ The remainder is in horticulture and cropping (1\%), inland water and wetlands $(6.2 \%)$ and other land covers such as urban, alpine and mangroves $(0.9 \%)$. 
This exercise was a first attempt to contribute to the scientific debate about the implications of the most commonly used metric.

\subsection{Directions for future research}

This thesis is the first attempt to measure the implications of governance structures for land utilisation decisions. Because of data restrictions and my choice of methodology, I concentrate on three land-cover transitions. What Māori landowners do with their land in scrub and forest has implications for the long-term GHG emissions of the country. Some considerations for future research are outlined below.

(1) Explore motivations for land-cover transitions into scrub. It would be interesting to study whether these transitions are because Māori landowners make different active choices motivated by cultural values, or because they passively let land revert to scrub rather than maintain or develop pasture.

(2) I calculated emissions or sequestration for three specific land-cover transitions. For future research, having information about the age of forests or scrub would assist in estimating net emissions more accurately.

(3) My analysis on land-cover transitions involved a 15-year period, which may not be enough time to support conclusions about deforestation. The analysis could be extended six more years by using the land cover database (LCDB) version 5 , which includes land cover information for 2018/19 (Creative Commons Attribution 4.0 International, 2020). 


\section{General discussion}

The main objective of this study was to explore how Māori land governance structures influence decisions for land utilisation and hence greenhouse gas (GHG) emissions associated with rural activities on Māori freehold land.

In the preceding chapters, I have reviewed the complex system of Māori land law defined under the TTWM, its history and the current framework. Moreover, I have discussed three case studies of Māori farms administered by different governance structures involved in agribusiness, as examples of how these structures can help to optimise the operation of dairy or sheep and beef farms. I have also documented the experience of some Māori landowners, represented by board members, who decided to go on carbon farming. I extended this qualitative analysis with econometric modelling to measure the relationship between Māori land governance structures and land-cover choices. Finally, I built on the econometric analysis and explored the implications of GHG emissions, in terms of both carbon dioxide equivalent and warming, of three land-cover transitions - pasture to forestry, pasture to scrub and forestry to pasture, between 1997 and 2012. I have learned that:

Māori interests go beyond economic outcomes and include other factors such as social or environmental outcomes; therefore, preferences and strategic goals are multidimensional and intertemporal. Decisions made by previous generations and the welfare of the current and future generations drives land utilisation choices, investment or land allocation. Preferences and strategic goals can then be influenced by a desire to look after the land for the current and future generations, and reciprocity between the land and people. For example, an enterprise brings revenue for landowners and helps to sponsor activities for the whole community, such as education grants or looking after a marae.

Māori land governance structures do seem to be a promising option to help landowners make decisions. Having every piece of Māori freehold land administered by a governance structure would help Māori to cope with challenges associated with multiple ownership. However, the performance of a governance structure relies on levels of leadership, engagement, cooperation and trust between the board members and landowners. Moreover, as discussed in Chapter Two, decisions about the possible 
utilisation of Māori freehold land can take time, as this involves numerous steps and the consideration of potential effects on future generations.

Māori land governance structures can facilitate allocation of land into forestry, which can be motivated by an opportunity to access capital in the long term (as discussed in Chapter Two). A transition into forestry involves conversion costs (such as financial and decision costs), which these structures can help to address. Some questions were raised from my analysis: what would be achieved if every piece of Māori freehold land had a Māori land governance structure in place? Would decisions on land use that affect climate be different if there was a Māori land governance structure in place?

Measuring the way land-cover decisions influence the environment is not an easy task and results vary according to the methodology used to estimate GHG emissions. Moreover, it is not an easy task to disentangle the implications for global warming. Furthermore, the accuracy of the measurement relies on data use. I recognise the immense progress in the data available in Aotearoa New Zealand for analysis, but these improvements do not provide detailed information, for example, about land use or landowners' characteristics.

Māori have a profound love and respect for whenua (or land) that I cannot explain in words. Despite all the challenges after the Crown altered the customary regime, the attitudes towards land are still profoundly influenced by mātauranga Māori (Māori knowledge system). I greatly believe that mātauranga Māori can be of great help in finding solutions to the environmental problems all humans are experiencing.

Last but not least, this work indicates potential ideas for novel solutions to improve environmental and socio-economic outcomes in rural Colombia. This thesis provides an overview of lessons and consequences of title individualisation carried by the Crown in the 19th century, which is still having consequences in the current decision-making process of Māori landowners. I have found the integration of many aspects of Māori culture into mainstream culture in Aotearoa New Zealand fascinating. This integration is reflected, for example, in how decisions on land utilisation are influenced by cultural, social and economic imperatives, or in a legal framework that aims to guarantee the retention, use, control and development of Māori freehold land by Māori 'landowners'. 


\section{References}

Abadie, A., Athey, S., Imbens, G. W., \& Wooldridge, J. (2017). When should you adjust standard errors for clustering? (Working Paper No. 24003). National Bureau of Economic Research: Retrieved from https://www.nber.org/papers/w24003

Agrawal, A. (2001). Common property institutions and sustainable governance of resources. World Development, 29(10), 1649-1672. https://doi.org/10.1016/S0305-750X(01)00063-8

Allen, M. (2015). Short-lived promise? The science and policy of cumulative and short-lived climate pollutants. Retrieved from https://www.oxfordmartin.ox.ac.uk/downloads/briefings/Short_Lived_Promise.pdf Allen, M., Shine, K., Fuglestvedt, J. S., Millar, R. J., Cain, M., Frame, D. J., \& Macey, A. H. (2018). A solution to the misrepresentations of $\mathrm{CO} 2$-equivalent emissions of short-lived climate pollutants under ambitious mitigation. Nature Partner Journals (NPJ). Climate and Atmospheric Science, 1(1). 1-8. https://doi.org/10.1038/s41612-018-0026-8

Anastasiadis, S., Kerr, S., Daigneault, A., Doole, G., Greenhalgh, S., Montes de Oca, O., Rutledge, D., \& Turner, J. (2013). Understanding the practice of land use modelling. Retrieved from https://motu.nz/our-work/environment-and-resources/lurnz/lurnzoverview/understanding-the-practice-of-land-use-modelling/

Anastasiadis, S., Kerr, S., Zhang, W., Allan, C., \& Power, W. (2014). Land use in rural New Zealand: Spatial land use, land-use change, and model validation (Motu Working Paper 14-07). Retrieved from www.motu.org.nz/publications/detail/land_use_in_rural_new_zealand_spatial_land_use_land -use_change_and_model_va

Anselin, L. (1988). Spatial econometrics: Methods and models. Dordrecht, The Netherlands: Kluwer Academic Publishers.

Anselin, L. (2001). Spatial effects in econometric practice in environmental and resource economics. American Journal of Agricultural Economics, 83(3), 705-710.

Anselin, L., Florax, R., \& Rey, S. (Eds.). (2004). Advances in spatial econometrics. Methodology, tools and applications. Berlin, Germany: Springer-Verlag.

Balcázar, A. \& Rodríguez, C. (2013). Tierra para uso agropecuaria. In J.P. Perfetti (Ed.), Políticas para el desarrollo de la agricultura en Colombia (pp. 65-114). Bogotá, Colombia: Fedesarrollo, Sociedad de Agricultores de Colombia (SAC), Incoder, Finagro, Banco Agrario.

Belgrave, M., Deason, A., \& Young, G. (2004). Crown policy with respect to Māori Land, 1953-1999 (Report No. A66). Prepared for the Crown Forestry Rental Trust's Central North Island Stage One Research Programme. 
Bennion, T. (2009). Māori land. In D. Brown, R. Thomas, E. Toomey, R. Muir, \& K. Palmer, New Zealand land law (2nd ed., pp. 293-343). Wellington, New Zealand: Brookers.

Beron, K., \& Vijverberg, W. (2004). Probit in a spatial context: A Monte Carlo analysis. In L. Anselin, R. Florax, \& S. Rey (Eds.), Advances in spatial econometrics. Methodology, tools and applications (pp. 169-196). Berlin, Germany: Springer-Verlag.

Besley, T. (1995). Property rights and investment incentives: Theory and evidence from Ghana. Journal of Political Economy, 103(5), 903-937. https://doi.org/10.1086/262008

Boast, R. (2004). Māori customary law and land tenure. In R. Boast (Ed.), Māori land law (2nd ed., pp. 21-40). Wellington, New Zealand: LexisNexis.

Boast, R. (2008). Buying the land, selling the land: Governments and Māori land in the North Island 1865-1921. Wellington, New Zealand: Victoria University Press.

Bowerman, N., Frame, D., Huntingford, C., Lowe, J., Smith, S., \& Allen, M. (2013). The role of shortlived climate pollutants in meeting temperature goals. Nature Climate Change, 3, 1021-1024. https://doi.org/10.1038/nclimate2034

Cain, M., Lynch, J., Allen, M., Fuglestvedt, J. S., Frame, D. J., \& Macey, A. H. (2019). Improved calculation of warming-equivalent emissions forshort-lived climate pollutants. Nature Partner Journals (NPJ). Climate and Atmospheric Science, 2(1). 1-7. https://doi.org/10.1038/s41612-019-0086-4

Carrion-Flores, C., Flores-Lagunes, A., \& Guci, L. (2009). Land use change: A spatial multinomial choice analysis (2009 Annual Meeting, 26-28 July 2009, Milwaukee, Wisconsin, No. 49403). Retrieved from https://ideas.repec.org/p/ags/aaea09/49403.html

Carrion-Flores, C., \& Irwin, E. G. (2004). Determinants of residential land-use conversion and sprawl at the rural-urban fringe. American Journal of Agricultural Economics, 86(4), 889-904.

Carswell, F., Harmsworth, G., Kerr, S., Kirikiri, R., \& Turney, I. (2002). A framework for engagement of Māori landowners in "carbon farming" using indigenous forest regeneration (Landcare Research Contract Report: LC0102/116). Lincoln, New Zealand: Manaaki Whenua Landcare Research. Retrieved from https://motu.nz/our-work/environment-andresources/emission-mitigation/emissions-trading/a-framework-for-engagement-of-maorilandowners-in-carbon-farming-using-indigenous-forest-regeneration/

Carver, T., Dawson, P., \& Kerr, S. (2017). Including forestry in an Emissions Trading Scheme: Lessons from New Zealand (Motu Working Paper 17-11). Wellington, New Zealand: Motu Economic and Public Policy Research Trust. Retrieved from https://motu.nz/ourwork/environment-and-resources/emission-mitigation/emissions-trading/includingforestry-in-an-emissions-trading-scheme-lessons-from-new-zealand/

Carver, T., \& Kerr, S. (2017). Facilitating carbon offsets from native forests (Motu Working Paper 17-01). Wellington, New Zealand: Motu Economic and Public Policy Research Trust. 
Retrieved from https://motu.nz/our-work/environment-and-resources/emissionmitigation/emissions-trading/facilitating-carbon-offsets-from-native-forests/

Chakir, R., \& Parent, O. (2009). Determinants of land use changes: A spatial multinomial probit approach. Papers in Regional Science, 88(2), 327-344. https://doi.org/10.1111/j.14355957.2009.00239.x

Chomitz, K., \& Gray, D. (1996). Roads, land use, and deforestation: A spatial model applied to Belize. The World Bank Economic Review, 10(3), 487-512. https://doi.org/10.1093/wber/10.3.487

Ciriacy-Wantrup, S. von, \& Bishop, R. (1975). "Common property” as a concept in natural resources policy. Natural Resources Journal, 15(4), 713-727.

Climate Change Response (Emissions Trading Reform) Amendment Act 186-1 (2019). Retrieved from http://legislation.govt.nz/bill/government/2019/0186/latest/LMS143384.htm

Commons, J. (1974). Legal foundations of capitalism. New York, NY: Clifton N.J. A. M. Kelley.

Cortés Acosta, S., Fleming, D., Henry, L., Lou, E., Owen, S., \& Small, B. (2019). Identifying barriers to adoption of "no-cost" greenhouse gas mitigation practices in pastoral systems (Motu Working Paper 19-10). Retrieved from https://motu.nz/our-work/environment-andresources/agricultural-economics/no-cost-barriers/identifying-barriers-to-adoption-of-nocost-greenhouse-gas-mitigation-practices-in-pastoral-systems/

Cortés Acosta, S., Grimes, A., \& Leining, C. (forthcoming). Decision trees: Permanent forestry in the New Zealand Emissions Trading Scheme. (Motu Working Paper draft version).

Creative Commons Attribution 3.0 New Zealand. (2017). Department of Conservation (DOC) public conservation areas. Retrieved from https://koordinates.com/layer/754-doc-publicconservation-areas/

Creative Commons Attribution 4.0 International. (2020). LCDB v5.0 - Land cover database version 5.0: Mainland New Zealand. Retrieved from https://lris.scinfo.org.nz/layer/104400lcdb-v50-land-cover-database-version-50-mainland-new-zealand/

Cronin, K., Nicholas, G., Doody, B., Foote, J., Greenaway, A., Harmsworth, G., \& Winstanley, A. (2012). Responding to climate change in the land-based sectors: A social science research strategy for New Zealand. Full report (MPI Technical Paper No: 2012/35). Wellington, New Zealand: Ministry for Primary Industries. Retrieved from http://www.mpi.govt.nz/dmsdocument/4062/loggedIn.

Daigneault, A., Wright, W., \& Samarasinghe, O. (2015). Economic analysis of land use opportunities in Maniapoto rohe (Landcare Research Report LC2415). Retrieved from http://www.maniapoto.iwi.nz/wp-content/uploads/2016/04/1.-Economic-Analysis.pdf

Deininger, K., \& Feder, G. (2001). Land institutions and land markets. In B. L. Gardner \& G. C. Rausser (Eds.), Handbook of Agricultural Economics: Vol. 1, Part A (pp. 287-331). Retrieved 
from https://www.sciencedirect.com/handbook/handbook-of-agriculturaleconomics/vol/1/part/PA

Department for Courts. (2001). Māori land trusts: A guide. Te Ture Whenua Māori Act 1993. Retrieved from http://ndhadeliver.natlib.govt.nz/delivery/DeliveryManagerServlet?dps_pid=IE1712329\&dp s_custom_att_1=ilsdb

Dewes, W., Walzl, T., \& Martin, D. (2011). Owners' aspirations regarding the utilisation of Māori land. Retrieved from https://www.tpk.govt.nz/en/a-matou-mohiotanga/land/ownersaspirations-regarding-the-utilisation-of-ma/

Dickson, I., Hensen, M., \& Madden, P. (2009). Economics of alternative land use on Crown Forest licensed land (Report to Crown Forestry Rental Trust). Wellington, New Zealand. Retrieved from http://cfrt.org.nz/wp/wpcontent/uploads/2018/05/EconomicsofAlternativeLandUseonCrownForestLicensedLand.pd $\mathrm{f}$

Dorner, Z., Djanibekov, U., Soliman, T., Stroombergen, A., Kerr, S., Fleming, D. A., Cortés-Acosta, S., \& Greenhalgh, S. (2018). Land-use change as a mitigation option for climate change (Report to the Biological Emissions Reference Group). Wellington, New Zealand. Retrieved from https://motu.nz/our-work/environment-and-resources/agriculturaleconomics/agricultural-greenhouse-gas-emissions/land-use-change-as-a-mitigation-optionfor-climate-change/

Dorner, Z., \& Hyslop, D. (2014). Modelling changing rural land use in New Zealand 1997 to 2008 using a multinomial logit approach (Motu Working Paper No. 14-12). Retrieved from http://www.motu.org.nz/publications/detail/modelling_changing_rural_land_use_in_new_ze aland_1997_to_2008_using_a_multi

Dowd, B., Greene, W., \& Norton, E. (2014). Computation of standard errors. Health Services Research, 49(2), 731-750. https://doi.org/10.1111/1475-6773.12122

Durie, E. (1987). The law and the land. In J. Phillips (Ed.), Te Whenua, te iwi. The land and the people (pp. 78-81). Wellington, New Zealand: Allen \& Unwin/Port Nicholson Press in association with the Stout Research Centre for the Study of New Zealand Society, History and Culture.

Durie, M. (1998). Te mana, te kāwanatanga: The politics of Māori self-determination. Auckland, New Zealand: Oxford University Press.

Durie, M. (1999). Māori development: Reflections and strategic directions. He Pukenga Kōrero. A Journal of Māori Studies, 5(1), 4-11.

Durie, M. (2010). Outstanding universal value: How relevant is indigeneity? In R. Selby, P. Moore, \& M. Mulholland (Eds.), Mãori and the environment: Kaitiaki (1st ed., pp. 239-249).

Wellington, New Zealand: Huia. 
Dymond, J. R., Ausseil, A.-G. E., Ekanayake, J. C., \& Kirschbaum, M. U. F. (2012). Tradeoffs between soil, water, and carbon - A national scale analysis from New Zealand. Journal of Environmental Management, 95(1), 124-131.

https://doi.org/10.1016/j.jenvman.2011.09.019

Elo, S., \& Kyngäs, H. (2008). The qualitative content analysis process. Journal of Advanced Nursing, 62(1), 107-115. https://doi.org/10.1111/j.1365-2648.2007.04569.x

Fleras, A., \& Spoonley, P. (1999). Recalling Aotearoa: Indigenous politics and ethnic relations in New Zealand. Auckland, New Zealand: Oxford University Press.

Foster, M. (1997). Instrumental variables for logistic regression: An illustration. Social Science Research, 26(4), 487-504. https://doi.org/10.1006/ssre.1997.0606

Frischmann, Brett M., Marciano, A., \& Ramello, G. B. (2019). Retrospectives: Tragedy of the commons after 50 years. Journal of Economic Perspectives 33(4), 211-228. https://doi.org/ $10.1257 /$ jep.33.4.211

Funk, J. (2009). Carbon farming in New Zealand: An interdisciplinary assessment of indigenous reforestation as a land-use system (Doctoral dissertation, Stanford University). Retrieved from https://search.proquest.com/docview/305008260/

Funk, J., Field, C., Kerr, S., \& Daigneault, A. (2014). Modelling the impact of carbon farming on land use in a New Zealand landscape. Environmental Science \& Policy, 37, 1-10. https://doi.org/10.1016/j.envsci.2013.08.008

Geist, H., McConnell, W., Lambin, E., Moran, E., Alves, D., \& Rudel, T. (2006). Causes and trajectories of land-use/cover change. In E. F. Lambin \& H. Geist (Eds.), Land-use and landcover change (pp. 41-70). https://doi.org/10.1007/3-540-32202-7_3

Gordon, S. (1954). The economic theory of a common-property resource: The fishery. Journal of Political Economy, 62(2), 124-142.

Grafton, R. Q. (2000). Governance of the commons: A role for the state? Land Economics, 76(4), 504-517. https://doi.org/10.2307/3146949

Greene, W. (2009). Discrete choice modeling. In T. C. Mills \& K. Patterson (Eds.), Palgrave handbook of econometrics: Volume 2: Applied econometrics (pp. 473-556). Retrieved from https://link.springer.com/book/10.1057\%2F9780230244405

Greene, W. (2012). Econometric analysis (7th ed). Boston, MA: Prentice Hall.

Hardin, G. (1968). The tragedy of the commons. Science, 162(3859), 1243-1248.

Harmsworth, G. (2003). Māori perspectives on Kyoto policy: Interim results. Reducing greenhouse gas emissions from the terrestrial biosphere (Landcare Research Report: LC0203/084). Lincoln, New Zealand: Manaaki Whenua Landcare Research. Retrieved from https://www.landcareresearch.co.nz/_data/assets/pdf_file/0004/43834/maori_perspectiv es_kyoto_interim.pdf 
Harmsworth, G. (2018). Landcover class (LCDBv4) intersected with Māori land blocks for New Zealand. Lincoln, New Zealand: Manaaki Whenua Landcare Research.

Harmsworth, G., \& Awatere, S. (2013). Indigenous Māori knowledge and perspectives of ecosystems. In J. Dymond (Ed.), Ecosystem services in New Zealand. Conditions and trends (1st ed., pp. 274-286). Retrieved from https://www.landcareresearch.co.nz/_data/assets/pdf_file/0007/77047/2_1_Harmsworth. pdf

Harmsworth, G., Tahi, M., \& Insley, C. K. (2010). Climate change business opportunities for Mãori land and Mãori organisations. (MPI Technical Paper No: 2012/43). Retrieved from https://www.mpi.govt.nz/dmsdocument/13942/loggedIn

Harvey, L. R. (2018). Would the proposed reforms affecting Ahu Whenua trusts have impeded hapu in the development of their lands? A Ngāti Awa perspective (Unpublished PhD thesis). The Auckland University of Technology, Auckland, New Zealand. Retrieved from https://openrepository.aut.ac.nz/handle/10292/11994

Hausman, J., \& McFadden, D. (1984). Specification tests for the multinomial logit model. Econometrica, 52(5), 1219-1240. https://doi.org/10.2307/1910997

Heal, G. (2019). Climate economics: A meta-review and some suggestions (Working Paper No. 13927). National Bureau of Economic Research: Retrieved from https://www.nber.org/papers/w13927.pdf

Heilmayr, R. (2015). Chile's forest transition: Foreshadowing global timber markets and governance (Unpublished PhD thesis). Stanford University, Stanford, California. Retrieved from https://searchworks.stanford.edu/view/11513059

Held, I., \& Soden, B. (2006). Robust responses of the hydrological cycle to global warming. Journal of Climate, 19(21), 5686-5699. https://doi.org/10.1175/JCLI3990.1

Hoffman, S., \& Duncan, G. (1988). Multinomial and conditional logit discrete-choice models in demography. Demography, 25(3), 415-427. https://doi.org/10.2307/2061541

Hosmer, D., \& Lemeshow, S. (2000). Applied logistic regression (2nd ed.). Hoboken, NJ: John Wiley \& Sons, Inc.

Hsieh, W.H., Irwin, E. G., \& Forster, D. L. (2000). Spatial dependence among county-level land use changes (Doctoral dissertation, The Ohio State University). Retrieved from https://search.proquest.com/docview/1697460781/abstract/716FEEDA607845FDPQ/1

Hyde, W. F., Amacher, G. S., \& Magrath, W. (1996). Deforestation and forest land use: Theory, evidence, and policy implications. The World Bank Research Observer, 11(2), 223-248. Retrieved from https://www.jstor.org/stable/3986432?seq=1\#metadata_info_tab_contents Ibañez, A. M., \& Muñoz, J. C. (2010). The persistence of land concentration in Colombia: What happened between 2000 and 2010? In M. Bergsmo, C. Rodríguez-Garavito, P. Kalmanovitz, \& M. P. Saffon (Eds.), Distributive justice in transitions (pp. 279-310). Retrieved from 
https://www.researchgate.net/publication/237428329_The_Persistence_of_Land_Concentra tion_in_Colombia_What_Happened_Between_2000_and_2009

Insley, C. K., \& Meade, R. (2008). Māori impacts from the Emissions Trading Scheme. Detailed analysis and conclusions. Retrieved from https://www.mfe.govt.nz/sites/default/files/maori-impacts-analysis-conclusions-jan08.pdf Intergovernmental Panel on Climate Change. (2019). Inter Intergovernmental Panel on Climate Change (IPCC) updates methodology for greenhouse gas inventories. Retrieved from https://www.ipcc.ch/2019/05/13/ipcc-2019-

refinement/\#: :text=IPCC\%20Methodologies,human\%20activity\%20cause $\% 20$ global\%20w arming

Jaffe, A. B. (2017). Barriers to adoption of no-cost options for mitigation of agricultural emissions: A typology (Motu Note 24). Retrieved from http://motu.nz/our-work/environment-andresources/emission-mitigation/agricultural-greenhouse-gas-emissions/barriers-toadoption-of-no-cost-options-for-mitigation-of-agricultural-emissions-a-typology/

Jaffe, A. B., \& Stavins, R. N. (1995). Dynamic incentives of environmental regulations: The effects of alternative policy instruments on technology diffusion. Journal of Environmental Economics and Management, 29(3), S43-S63. https://doi.org/10.1006/jeem.1995.1060

Jones, C. (2014). A Māori constitutional tradition. New Zealand Journal of Public and International Law. 135(12), 187-203. Retrieved from https://papers.ssrn.com/sol3/papers.cfm?abstract_id=2538900

Journeaux, P., Kingi, T., \& West, G. (2016). Greenhouse gas mitigation modelling for Māori focus farms: Scenario Modelling Results. Hamilton, New Zealand: AgFrist Waikato Ltd. and Scion.

Kahui, V., \& Richards, A. C. (2014). Lessons from resource management by indigenous Māori in New Zealand: Governing the ecosystems as a commons. Ecological Economics, 102, 1-7. https://doi.org/10.1016/j.ecolecon.2014.03.006

Karpas, E., \& Kerr, S. (2011). Preliminary evidence on responses to the New Zealand forestry Emissions Trading System (Motu Working Paper 11-09). Retrieved from https://motu.nz/our-work/environment-and-resources/emission-mitigation/preliminaryevidence-on-responses-to-the-new-zealand-forestry-emissions-trading-scheme/

Kerr, S., \& Olssen, A. (2012). Gradual land-use change in New Zealand: Results from a dynamic econometric model (Motu Working Paper 12-06). Retrieved from http://www.motu.org.nz/publications/detail/gradual_landuse_change_in_new_zealand_results_from_a_dynamic_econometric_m

Kingi, T. (2004). Communal land tenure and indigenous economic development: Getting the institutions 'right'. Retrieved from: https://www.researchgate.net/publication/253906664_Communal_Land_Tenure_and_Indige nous_Economic_Development_Getting_the_Institutions_'Right 
Kingi, T. (2008a). Māori landownership and land management in New Zealand. In Australian Agency for International Development (AusAID), Making land work, Volume 2: Case studies on customary land and development in the Pacific (pp. 129-151). Retrieved from https://www.dfat.gov.au/sites/default/files/MLW_VolumeTwo_CaseStudy_7.pdf

Kingi, T. (2008b). Ahuwhenua - Māori land and agriculture. Retrieved from https://teara.govt.nz/en/ahuwhenua-maori-land-and-agriculture

Kingi, T. (2009). The future of the Māori agricultural sector. Primary Industry Management, 13(2), 23-26. Retrieved from http://www.nzipim.co.nz/Folder?Action=View\%20File\&Folder_id=120\&File=PIM\%20Jun09 \%20PDF.pdf

Kingi, T. (2013). Cultural bastion, farm optimisation and tribal agriculture in Aotearoa (New Zealand). Proceedings of the 22nd International Grassland Congress, Sydney, 2013, 18981904. Retrieved from http://www.grassland.org.nz/publications/nzgrassland_publication_2583.pdf

Kvale, S., \& Brinkmann, S. (2009). InterViews: Learning the craft of qualitative research interviewing (2nd ed.). Los Angeles, CA: SAGE Publications.

Lambin, E., Geist, H., \& Rindfuss, R. R. (2006). Introduction: Local processes with global impacts. In E. F. Lambin \& H. Geist (Eds.), Land-use and land-cover change (pp. 41-70). https://doi.org/10.1007/3-540-32202-7_3

Lambin, E. F., Turner, B. L., Geist, H. J., Agbola, S. B., Angelsen, A., Bruce, J. W., ... Xu, J. (2001). The causes of land-use and land-cover change: Moving beyond the myths. Global Environmental Change, 11(4), 261-269. https://doi.org/10.1016/S0959-3780(01)00007-3

Landcare Research. (2004). Land environments of New Zealand (LENZ) map 2002. Retrieved from https://motu.nz/our-work/environment-and-resources/lurnz/land-environments-ofnew-zealand-lenz-map-2002/

Landcare Research. (2015). About the New Zealand land cover database (LCDB). LCDB: New Zealand land cover database. Retrieved from http://www.lcdb.scinfo.org.nz/about-lcdb Landcare Research \& Ministry of Agriculture and Forestry. (2002). Land use capability (LUC) map 2002. Retrieved from http://motu.nz/our-work/environment-andresources/lurnz/land-use-capability-luc-map-2002/

Land Information New Zealand. (2012). Average New Zealand farm size by farm type. Retrieved from https://www.linz.govt.nz/system/files_force/media/pages-attachments/2012__average_farm_sizes_by_farm_type_0.pdf?download=1

Leining, C., \& Kerr, S. (2018). A Guide to the New Zealand Emissions Trading Scheme. (Report prepared for the Ministry for the Environment). Wellington, New Zealand. Retrieved from https://motu.nz/assets/Documents/our-work/environment-and-agriculture/climatechange-mitigation/emissions-trading/ETS-Explanation-August-2018.pdf 
Leonard, B., Parker, D., \& Anderson, T. (2020). Land quality, land rights, and indigenous poverty. Journal of Development Economics, 143, 102435. https://doi.org/10.1016/j.jdeveco.2019.102435

Lesage, J. P. (2000). Bayesian estimation of limited dependent variable spatial autoregressive models. Geographical Analysis, 32(1), 19-35. https://doi.org/10.1111/j.15384632.2000.tb00413.x

Libecap, G. D. (1989). Distributional issues in contracting for property rights. Journal of Institutional and Theoretical Economics (JITE) / Zeitschrift Für Die Gesamte Staatswissenschaft, 145(1), 6-24.

Li, M., Wu, J., \& Deng, X. (2013). Identifying drivers of land use change in China: A spatial multinomial logit model analysis. Land Economics, 89(4), 632-654.

Lubowski, R. (2002). Determinants of land-use transitions in the United States: Econometric analysis of changes among the major land-use categories (Doctoral dissertation, Harvard University). Retrieved from http://search.proquest.com/docview/305601394/

Lubowski, R., Plantinga, A., \& Stavins, R. (2008). What drives land-use change in the United States? A national analysis of landowner decisions. Land Economics, 84(4), 529-550.

Retrieved from https://www.jstor.org/stable/27647846?seq=1\#metadata_info_tab_contents Lynn, I., Manderson, A., Page, M., Harmsworth, G., Eyles, G., Douglas, G., Mackay, A., \& Newsome, P. (2009). Land use capability survey handbook (3rd Vol.). Retrieved from http://www.landcareresearch.co.nz/_data/assets/pdf_file/0017/50048/luc_handbook.pdf

Māori Affairs Act, No. 94 (1953). Retrieved from http://www.nzlii.org/nz/legis/hist_act/maa19531953n94152/

Māori Land Court (2019). Your Māori land: Māori land update. Retrieved from https://maorilandcourt.govt.nz/your-maori-land/maori-land-data-service/

Māori Trustee Act, No. 95 (1953). Retrieved from http://www.nzlii.org/nz/legis/hist_act/mta19531953n95200/mta19531953n95200.html

Māori Trustee Amendment Act, No.12 (2009). Retrieved from http://www.legislation.govt.nz/act/public/2009/0012/latest/DLM1583803.html

Marr, C. (1997). Public works takings of Māori land, 1840-1981. (Waitangi Tribunal Rangahaua Whanui series). Retrieved from https://www.waitangitribunal.govt.nz/assets/Documents/Publications/wt-theme-g-publicworks-takings-of-maori-land.pdf

Marsden, M. (2003). The woven universe: Selected writings of Rev. Māori Marsden. Te A. C. Royal (Ed.), Ōtaki, New Zealand: The Estate of Rev. Māori Marsden.

McFadden, D. (1973). Conditional logit analysis of qualitative choice behavior. In P. Zarembka (Ed.), Frontiers in economics (pp. 105-142). Retrieved from https://elsa.berkeley.edu/reprints/mcfadden/zarembka.pdf 
McFadden, D., \& Train, K. (2000). Mixed MNL models for discrete response. Journal of Applied Econometrics, 15(5), 447-470. https://doi.org/10.1002/10991255(200009/10)15:5<447::AID-JAE570>3.0.CO;2-1

McGinnis, M. D. (2011). An introduction to IAD and the language of the Ostrom Workshop: A simple guide to a complex framework. Policy Studies Journal, 39(1), 169-183. https://doi.org/10.1111/j.1541-0072.2010.00401.x

McMillen, D. (1992). Probit with spatial autocorrelation. Journal of Regional Science, 32(3), 335348. https://doi.org/10.1111/j.1467-9787.1992.tb00190.x

McPhail, D. (2004). Trusts relating to Māori land. In R. Boast (Ed.), Māori Land Law (2nd ed., pp. 163-191). Wellington, New Zealand: LexisNexis.

Mead, S. M. (2016). Tikanga Māori: Living by Māori values (Revised ed.). Wellington, New Zealand: Huia.

Ministry for Primary Industries. (2019). Emissions returns. Retrieved from https://www.mpi.govt.nz/growing-and-harvesting/forestry/forestry-in-the-emissionstrading-scheme/emissions-returns/

Ministry for the Environment. (2019a). New Zealand's Interactive Emissions Tracker. Retrieved from https://emissionstracker.mfe.govt.nz/\#NrAMBoEYF12TwCIByBTALo2wBM4eiQ7YAcSAxAO 4CG6qATgGbUA2LA+gEYCu66A9gDss0IA

Ministry for the Environment. (2019b). New Zealand's greenhouse gas inventory. Retrieved from https://www.mfe.govt.nz/climate-change/state-of-our-atmosphere-and-climate/newzealands-greenhouse-gas-inventory

Ministry of Agriculture and Forestry. (2011). Mãori agribusiness in New Zealand: A study of the Māori freehold land resource. Wellington, New Zealand: Policy Publications, MAF Policy.

Ministry of Justice \& Ministry for Primary Industries. (2017). Māori land spatial dataset. Retrieved from https://www.maorilandcourt.govt.nz/assets/Documents/Publications/MLC2017-05-Fact-Sheet-Maori-Land-Dataset.pdf

Motu Economic and Public Policy Research Trust. (2020). Environmental modelling. Retrieved from https://motu.nz/our-work/environment-and-resources/lurnz/

Müller, D. (2005). Stata in space: Econometric analysis of spatially explicit raster data. The Stata Journal, 5(2), 224-238. https://doi.org/10.1177/1536867X0500500207

Native Land Court Act, No. 43 (1894). Retrieved from http://www.nzlii.org/nz/legis/hist_act/nlca189458v1894n43262/

Native Lands Act, No. 42 (1862). Retrieved from http://www.nzlii.org/nz/legis/hist_act/nla186226v1862n42251/

Native Trustee Act, No. 21 (1920). Retrieved from http://www.nzlii.org/nz/legis/hist_act/nta192011gv1920n21259/ 
Nelson, G., Harris, V., Stone, S., Barbier, E., \& Burgess, J. (2001). Deforestation, land use, and property rights: Empirical evidence from Darién, Panama. Land Economics, 77(2), 187-205. https://doi.org/10.2307/3147089

Nelson, G., \& Hellerstein, D. (1997). Do roads cause deforestation? Using satellite images in econometric analysis of land use. American Journal of Agricultural Economics, 79(1), 80-88. https://doi.org/10.2307/1243944

Nelson, G., Pinto, A. D., Harris, V., \& Stone, S. (2004). Land use and road improvements: A spatial perspective. International Regional Science Review, 27(3), 297-325. https://doi.org/10.1177/0160017604266028

New Zealand Productivity Commission (2018). Low-emissions economy: Final report. Retrieved from https://www.productivity.govt.nz/assets/Documents/lowemissions/4e01d69a83/Productiv ity-Commission_Low-emissions-economy_Final-Report_FINAL_2.pdf

New Zealand Resource Management Act, No. 69 (1991). Retrieved from http://www.legislation.govt.nz/act/public/1991/0069/latest/DLM230265.html

North, D. (1986). The new institutional economics. Journal of Institutional and Theoretical Economics (JITE) / Zeitschrift Für Die Gesamte Staatswissenschaft, 142(1), 230-237.

North, D. (1990). Institutions, institutional change, and economic performance. Cambridge, England; New York, NY: Cambridge University Press.

Ocampo, J. A., (2014). Misión para la transformación del campo: Saldar la deuda histórica con el campo. Marco conceptual de la Misión para la transformación del campo. Retrieved from https://colaboracion.dnp.gov.co/CDT/Agriculturapecuarioforestal\%20y\%20pesca/Documen to\%20Marco\%2020141023.pdf

Organisation for Economic Co-operation and Development. (2015). Colombia: Policy priorities for inclusive development. Retrieved from https://www.oecd.org/about/publishing/colombia-policy-priorities-for-inclusivedevelopment.pdf

Ostrom, E. (1986). An agenda for the study of institutions. Public Choice, 48(1), 3-25.

Ostrom, E. (1990). Governing the commons: The evolution of institutions for collective action. Cambridge, England: Cambridge University Press.

Ostrom, E. (1993). Design principles in long-enduring irrigation institutions. Water Resources Research, 29(7), 1907-1912. https://doi.org/10.1029/92WR02991

Ostrom, E. (1999). Self-governance and forest resources (Occasional Paper No. 20). Retrieved from http://www.cifor.org/publications/pdf_files/OccPapers/OP-20.pdf

Ostrom, E. (2000). Collective action and the evolution of social norms. The Journal of Economic Perspectives, 14(3), 137-158. 
Ostrom, E. (2005). Understanding institutional diversity. Princeton, NJ: Princeton University Press.

Ostrom, E. (2008). Doing institutional analysis: Digging deeper than markets and hierarchies. In C. Ménard \& M. M. Shirley (Eds.), Handbook of new institutional economics (pp. 819-848). Berlin/Heidelberg, Germany: Springer. https://doi.org/10.1007/978-3-540-69305-5_31

Ostrom, E., Gardner, R., \& Walker, J. (1994). Rules, games, and common-pool resources. Ann Arbor, MI: University of Michigan Press.

Ostrom, E., \& Hess, C. (2007). Private and common property rights. Workshop in Political Theory and Policy Analysis, Indiana University. Retrieved from https://surface.syr.edu/sul/24

Parker, D. (2004). Land trusts and the choice to conserve land with full ownership or conservation easements. Natural Resources Journal, 44(2), 483-518.

Patton, M. Q. (2005). Qualitative research. In B. Everitt \& D. Howell, Encyclopedia of Statistics in Behavioral Science 3 (pp. 1633-36). Hoboken, NJ: John Wiley \& Sons, Inc. https://doi.org/10.1002/0470013192.bsa514

Phillips, J., \& Hulme, K. (1987). Te Whenua, Te iwi: The land and the people. Wellington, New Zealand: Allen \& Unwin/Port Nicholson Press in association with the Stout Research Centre for the Study of New Zealand Society, History and Culture.

Pierrehumbert, R. (2014). Short-lived climate pollution. Annual Review of Earth and Planetary Sciences, 42, 341-379. https://doi.org/10.1146/annurev-earth-060313-054843

Plantinga, A. J. (1996). The effect of agricultural policies on land use and environmental quality. American Journal of Agricultural Economics, 78(4), 1082-1091. https://doi.org/10.2307/1243864

Polyakov, M., \& Zhang, D. (2008). Property tax policy and land-use change. Land Economics, 84(3), 396-408. Retrieved from https://www.jstor.org/stable/27647833?seq=1\#metadata_info_tab_contents

Pricewaterhouse Coopers (PWC). (2013). Growing the productive base of Māori freehold land. Wellington, New Zealand: Ministry for Primary Industries.

Pricewaterhouse Coopers. (2014a). Economic analysis of prototype interventions to lift Mãori agribusiness productivity. Wellington, New Zealand: Ministry for Primary Industries.

Pricewaterhouse Coopers. (2014b). Growing the productive base of Māori land - further evidence and analysis. Wellington, New Zealand: Ministry for Primary Industries.

Pricewaterhouse Coopers. (2014c). Growing the productive base of Māori land - partial national cost-benefit analysis. Wellington, New Zealand: Ministry for Primary Industries.

Reisinger, A., \& Clark, H. (2016). Modelling agriculture's contribution to New Zealand's contribution to the Post-2020 Agreement (MPI Information Paper No: 2016/02). Wellington, New Zealand: Ministry for Primary Industries. Retrieved from https://www.mpi.govt.nz/dmsdocument/11362/direct 
Resource Management Act, No. 69. (1991). Retrieved from

http://www.legislation.govt.nz/act/public/1991/0069/latest/DLM230265.html

Ricardo, D. (1821). On the principles of political economy and taxation (3rd ed.). London, England: John Murray.

Robertson, R., Nelson, G., \& De Pinto, A. (2009). Investigating the predictive capabilities of discrete choice models in the presence of spatial effects. Papers in Regional Science, 88(2), 367-388. https://doi.org/10.1111/j.1435-5957.2009.00247.x

Schlager, E., \& Ostrom, E. (1992). Property-rights regimes and natural resources: A conceptual analysis. Land Economics, 68(3), 249-262. https://doi.org/10.2307/3146375

Schneider, R. (1993). Land abandonment, property rights, and agricultural sustainability in the Amazon (LATEN Dissemination Note 3). Retrieved from http://documents.worldbank.org/curated/en/386481468742151434/Land-abandonmentproperty-rights-and-agricultural-sustainability-in-the-Amazon

Sinclair, D. (1977). Land: Māori view and European response. In M. King (Ed.), Te Ao hurihuri. The world moves on. Aspects of Māoritanga. (Revised version). Wellington, New Zealand: Hicks Smith \& Sons/Methuen NZ Ltd.

Small, Bruce. 2012. Aohanga incorporation: Climate change mitigation and adaptation: A social process framework for engagement and the development of a climate change resilience strategy (MAF Technical Paper: RE500/2012/008). Wellington, New Zealand: Ministry for Primary Industries. Retrieved from https://www.mpi.govt.nz/dmsdocument/4102/send

Small, K., \& Hsiao, C. (1985). Multinomial logit specification tests. International Economic Review, 26(3), 619-627. https://doi.org/10.2307/2526707

Smith, L. (2012). Decolonizing methodologies: Research and indigenous peoples (2nd ed.). London, England: Zed Books.

Stavins, R., \& Jaffe, A. (1990). Unintended impacts of public investments on private decisions: The depletion of forested wetlands. American Economic Review, 80(3), 337.

Te Puni Kōkiri. (2014a). The actual utilisation and economic value of Māori land. Wellington, New Zealand: Te Puni Kōkiri.

Te Puni Kōkiri. (2014b). The potential utilisation of Māori land. Wellington, New Zealand: Te Puni Kōkiri.

Te Ture Whenua Māori Act, No. 4. (1993). Retrieved from http://www.legislation.govt.nz/act/public/1993/0004/latest/DLM289882.html

Te Ture Whenua Māori Bill, Government Bill 126-2 (2016). Retrieved from http://www.legislation.govt.nz/bill/government/2016/0126/latest/DLM6388702.html

Te Uru Rākau (2019a). Using the field measurement approach. Retrieved from https://www.teururakau.govt.nz/growing-and-harvesting/forestry/forestry-in-theemissions-trading-scheme/using-the-field-measurement-approach/ 
Te Uru Rākau (2019b). A better Emissions Trading Scheme for forestry. proposed changes to the Climate Change (Forestry Sector) Regulations 2008 to support amendments to the Climate Change Response Act 2002. (Discussion Paper No: 2019/01). Retrieved from https://www.mpi.govt.nz/dmsdocument/37844-a-better-emissions-trading-scheme-forforestry-proposed-changes-to-the-climate-change-forestry-sector-regulations-discussiondocument

Tietenberg, T., \& Lewis, L. (2014). Environmental and natural resource economics (10th Ed.). London, England: Routledge.

Timar, L. (2011). Rural land use and land tenure in New Zealand (Motu Working Paper 11-13). Retrieved from http://motu-www.motu.org.nz/wpapers/11_13.pdf

Timar, L. (2016). Yield to change: Modelling the land-use response to climate-driven changes in pasture production (Motu Working Paper 16-15). Retrieved from https://motu.nz/ourwork/environment-and-resources/lurnz/yield-to-change-modelling-the-land-use-responseto-climate-driven-changes-in-pasture-production/

Timar, L. (2018a). Land Use Rural New Zealand (LURNZ) technical appendix. Wellington, New Zealand: Motu Economic and Public Policy Research Trust.

Timar, L. (2018b). Policy Driven 1.1 Path 5. Wellington, New Zealand: Motu Economic and Public Policy Research Trust.

Timar, L. \& Kerr, S. (2014). Land-use intensity and greenhouse gas emissions in the LURNZ model (Motu Working Paper 14-03). Retrieved from https://motu.nz/our-work/environment-andresources/lurnz/land-use-intensity-and-greenhouse-gas-emissions-in-the-lurnz-model/

Tobler, W. R. (1970). A computer movie simulating urban growth in the Detroit region. Economic Geography, 46, 234-240. https://doi.org/10.2307/143141

Todd, M., \& Kerr, S. (2009). How does changing land cover and land use in New Zealand relate to land use capability and slope? (Motu Working Paper 09-17). Retrieved from http://motu.nz/our-work/environment-and-resources/lurnz/how-does-changing-landcover-and-land-use-in-new-zealand-relate-to-land-use-capability-and-slope/

Train, K. (2009). Discrete choice methods with simulation (2nd ed.). Retrieved from http://ebooks.cambridge.org/ref/id/CBO9780511805271

Trustee Companies Act, No. 35 (1967). Retrieved from http://www.legislation.govt.nz/act/public/1967/0035/latest/whole.html

Tucker, C., \& Ostrom, E. (2005). Multidisciplinary research relating institutions and forest transformation. In E. Ostrom \& E. Moran (Eds.), Seeing the forest and the trees. Humanenvironment interactions in forest ecosystems (pp. 81-103). Cambridge, MA: MIT Press.

Vaismoradi, M., Turunen, H., \& Bondas, T. (2013). Content analysis and thematic analysis: Implications for conducting a qualitative descriptive study. Nursing \& Health Sciences, 15(3), 398-405. https://doi.org/10.1111/nhs.12048 
Vendryes, T. (2014). Peasants against private property rights: A review of the literature. Journal of Economic Surveys, 28(5), 971-995. https://doi.org/10.1111/j.1467-6419.2012.00743.x

Von Thünen, J. H. (1966). Von Thünen's isolated state: An English edition of Der isolierte Staat (C. Wartenberg, Trans.). Oxford, England: Pergamon Press.

Wade, R. (1987). The management of common property resources: Collective action as an alternative to privatisation or state regulation. Cambridge Journal of Economics, 11(2), 95106.

Waitangi Tribunal. (2003). Te Whanganui a Tara: Me Ona Takiwa (Waitangi Tribunal Report 2003 No. WAI 145). Retrieved from https://forms.justice.govt.nz/search/Documents/WT/wt_DOC_68452530/Wai145.pdf

Waitangi Tribunal. (2008). Papatuanuku (Papaahurewa/Papauenoko) and land ownership: Maori land alienation, and Maori land and title administration in the Central North Island (Waitangi Tribunal Report 2008 No. Wai 1200 Volume 3). Retrieved from https://forms.justice.govt.nz/search/WT/reports.html

Waitangi Tribunal. (2016). He Kurawhenua Karokohanga: Report on claims about the reform of Te Ture Whenua Māori Act 1993. (Waitangi Tribunal Report 2016 No. Wai 2478). Retrieved from https://forms.justice.govt.nz/search/Documents/WT/wt_DOC_101113166/Te\%20Ture\%20 Whenua\%20Pre-pub\%20W.pdf

Watson, R., Noble, I., Bolin, B., Ravindranath, N. H., Verardo, D., \& Dokken, D. (2000). Land use, land-use change and forestry. Cambridge, England: Cambridge University Press. Retrieved from https://archive.ipcc.ch/ipccreports/sres/land_use/index.php?idp=0

West, G., Journeaux, P., Wakelin, S., \& Kingi, T. (2016). Collective land tenure systems and greenhouse gas mitigation among Māori farmers in Aotearoa, New Zealand. In D. D. W. Kuan \& P. D'Arcy (Eds.), Islands of hope: Pan Pacific indigenous resource management in the era of globalisation and climate change. Canberra, Australia: Australian National University Press. Retrieved from https://www.researchgate.net/publication/318700638_Collective_land_tenure_systems_and _greenhouse_gas_mitigation_options_among_Maori_farmers_in_New_Zealand

White, P. I. (1997). How do Māori land owners judge whether the management of Mãori incorporations is successful? (Unpublished Master's thesis). Massey University, Palmerston North, New Zealand. Retrieved from http://mro.massey.ac.nz/handle/10179/960 Yin, R. K. (2012). Applications of case study research (3rd ed.). Thousand Oaks, CA: SAGE. Yin, R. K. (2015). Case studies. In J Wright (Ed.), International Encyclopedia of the Social \& Behavioral Sciences (Second Edition, pp. 194-201). Amsterdam, The Netherlands: Elsevier. https://doi.org/10.1016/B978-0-08-097086-8.10507-0 



\title{
Appendices
}

\section{Appendix A}

\section{Document 1-1 Participant information sheet}

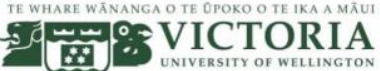 \\ Land governance structures and greenhouse gas emissions: lessons from Māori \\ INFORMATION SHEET FOR PARTICIPANTS
}

Kia ora tātou, thank you for your interest in the project. Please read this information before deciding to take part. If you decide to participate, thank you.

\section{Who am I?}

My name is Sandra Cortés-Acosta. I am a Doctoral student in Environmental Studies, working under the supervision of Professor Dave Frame, Dr Carwyn Jones and Dr Suzi Kerr. This research project is work towards my PhD thesis.

\section{What is the aim of the project?}

The primary goal of this project is to enhance understanding of decision-making processes within Mãori land governance structures (i.e. Trust, Incorporation, Limited Liability Company or Partnership). I will focus on decisions about using farm practices that lower a farm's environmental footprint without reducing the profitability of the farm. I will ask questions about how the decision process is shaped, preferences, information-process abilities, the strategic goals of the group, and cost-benefit considerations about potential outcomes.

My research is conducted as part of the project Barriers to Adoption of 'no-cost' Mitigation Options. This project is in coordination with Motu Research, Landcare and AgResearch and seeks to better understand why some apparent 'no-cost' options for agricultural mitigation (reduction of biological greenhouse gas emissions) remain non- or under-adopted in practice. No-cost mitigation options are investments, technologies or practices whose adoption: 1. reduces the farm's greenhouse gas emissions, and 2 . does not reduce the profitability of the farm.

This research has been approved by the Victoria University of Wellington Human Ethics Committee 24856

How can you help?

If you agree to take part I will interview you in person and (ideally) on your farm, but if it is necessary the interview could be conducted over the phone. I will ask you questions about the current management of the farm; what happens when a new option of farm management is identified; how preferences are defined and formulated; how the option is evaluated and possible cost-benefit considerations; how the coordination and selection of an option is done; and finally why the option is adopted.

The interview will take approximately one hour. It is possible that Tanira Kingi from Scion or Sally Owen from Motu Research will be present during the interview. I will record the interview and you will have access to the interview recording and a summary of it. You can stop the interview at any time, without giving a reason. You can withdraw from the study by contacting me at any point before September 2017. If you withdraw, the information you provided will be destroyed or returned to you. 


\section{Document 1-1 Participant information sheet (continued)}

\section{What will happen to the information you give?}

This research is confidential. This means that the researchers named below will be aware of your identity but the research data will be aggregated and your identity will not be disclosed in any reports, presentations, or public documentation. However, you should be aware that in small projects your identity might be obvious to others in your community.

Only my supervisors and I will have access to the recording or notes of the interview. The interview summaries and any recordings will be kept securely and any identifiable research data will be destroyed immediately after the conclusion of the research

\section{What will the project produce?}

The information from my research will be used in my PhD dissertation, academic reports and/or presented at conferences. By using case studies of Māori Farms I aim to bring a comparison of the decision-making process within Māori land governance structures (i.e. Trust, Incorporation, Limited Liability Company or Partnership) on communally owned Māori land.

I will conduct my research in a way that supports what Mãori land governance structures have been doing and their farm management processes. I will share the results of my research with all participants when I finish my analysis.

If you accept this invitation, what are your rights as a research participant?

If you do decide to participate, you have the right to:

- choose not to answer any question;

- $\quad$ ask for the recorder to be turned off at any time during the interview;

- $\quad$ withdraw from the study before September 2017;

- ask any questions about the study at any time;

- receive a copy of your interview recording;

- $\quad$ read over and comment on a written summary of your interview;

- be able to read any reports of this research by emailing the researcher to request a copy.

If you have any questions or problems, who can you contact?

If you have any questions, either now or in the future, please feel free to contact either:

Student (myself)

Sandra Cortés-Acosta

sandra.cortes-acosta@vuw.ac.nz

Supervisors:

Carwyn Jones

Senior Lecturer

Faculty of Law

Suzi Kerr

Adjunct Professor

Dave Frame

carwyn.jones@vuw.ac.nz

School of Government

Professor

School of Geography, Environment and Earth Sciences

david.frame@vuw.ac.nz

Human Ethics Committee information

If you have any concerns about the ethical conduct of the research you may contact the Victoria University HEC

Convener: Associate Professor Susan Corbett. Email susan.corbett@vuw.ac.nz or telephone +64-4-463 5480. 


\section{Document 1-2 Consent form}

\section{TO WHARE WXNANGA O TE OPOKO O TE IKA MÃU \\ Land governance structures and greenhouse gas emissions: lessons from Māori CONSENT TO INTERVIEW \\ This consent form will be held for three years.}

Researcher: Sandra Cortés-Acosta, School of Geography, Environment and Earth Science, Victoria University of Wellington.

Supervisors: Professor Dave Frame, Dr Carwyn Jones and Dr Suzi Kerr.

- I have read the Information Sheet and the project has been explained to me. My questions have been answered to my satisfaction. I understand that I can ask further questions at any time.

- I agree to take part in an audio recorded interview.

I understand that:

- I may withdraw from this study at any point before September 2017, without giving any reason, and any information that I have provided will be returned to me or destroyed.

- The information I have provided will be destroyed two years after the research is finished.

- $\quad$ Any information I provide will be kept confidential to the researcher and the supervisors. I understand that the results will be used for a PhD dissertation, academic reports and/or presented at conferences.

- My name will not be used in reports, nor will any information that would identify me.

- I will have access to the recording of my interview and a summary of it.

- My name will not be used in reports, nor will any information that would identify me.

- I consent to information or opinions which I have given being attributed to my organisation in any reports on this research:

- I would like a copy of the recording of my interview:

Yes $\square \quad$ No $\square$

- I would like a summary of my interview:

Yes $\square \quad$ No $\square$

- I would like to receive a copy of the final report and have added my email address below:

Signature of participant:

Name of participant:

Date:

Contact details: 


\section{Document 1-3 Question guide}

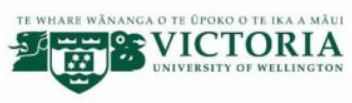

Land governance structures and greenhouse gas emissions: lessons from Māori

Semi-structured interview questions guide

a. Explain my purpose; ask permission to record the interview.

The primary goal of this project is to enhance understanding of decision-making processes within Māori land governance structures (i.e. Trust, Incorporation, Limited Liability Company or Partnership). I focus on decisions about using farm practices.

b. Outline questions

I. Farm description and current management.

- Ownership status and owner characteristics:

1. What is the land governance structure?

2. When was the land governance structure constituted for this farm and why?

3. How is the land governance structure organised?

4. What skills/characteristics do they have?

5. Is the farm involved in a Treaty Settlement that will bring land back into the hapu $/$ Iwi? If so, is this land part of the farm?

- Decision structure:

6. Who is involved in the decision-making process of the farm and how?

7. When do they meet? What do they do when they meet?

8. How is the information shared with the decision-makers?

- Management of the land:

9. What are the current enterprises (i.e. forestry, dairy) on the farm? How much land is devoted to each activity? How long has it been managed in this way? 10. How that has changed in the las 10 years? What have it changed?

11. Are you looking to diversify in the future?

12. What improvements would you like to see in the current state?

II. Initiation of decision-making process.

13. Who brings information about possible farm practices to decision-makers?

14. Where do they get information about potential strategies?

III. Formation of strategic objectives for management.

15. What are the current goals and vision overall for the farm?

16. What cultural values are involved in the management of the farm?

17. Do the number of workers follows the standard of the industry or are they follow by cultural values? 


\section{Document 1-3 Question guide (continued)}

IV. Consideration of options and their potential to meet objectives.

18. What factors facilitate effective decisions? Or what factors inhibit or prevent effective decisions?

19. Does the farm have a risk assessment or management? To what extent is management affected by this?

V. Selection of options.

20. What would facilitate and implement new farm practices on the farm?

21. What are key drivers for adopting some farm practice?

22. What factors affect the selection of a farm practices?

VI. Adoption of an option.

23. How are decisions and strategies assessed? What typically makes a decision or strategy successful?

24. Who implements the decision, once they are made? Is there a review process in place once implementation has happened? 


\section{Appendix B}

Document 2-1 Participant information sheet

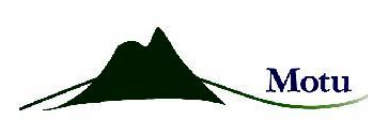

Participant Information Sheet
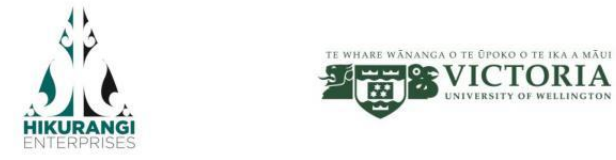

Tēna koutou, thank you for your interest in this project. Please read this information before deciding to take part. If you decide to participate, thank you.

\section{What is the aim of the project?}

The overarching project seeks to find ways that Māori landowners or communities could benefit from native forest regeneration using funds through the Emissions Trading Scheme (ETS). The purpose of this particular research (interview) is to analyse how Māori land owners have made choices about carbon farming in the past (if any), its alternatives, and sustainable land management. The project will seek to better understand the decision-making process and its development over time.

\section{What will the project produce?}

The project will produce a public report of the lessons learnt. It will also inform academic work on adoption of carbon farming, and may be used in the PhD dissertation of one of the research team (Sandra Cortés-Acosta). We will share the results of the research with all participants when we finish the analysis.

\section{How can you help?}

If you agree to take part we will interview you in person. We will ask questions about you and your community's experiences of carbon farming, and your thoughts on what could make carbon farming an attractive option for you now. The interview will take approximately one hour and will be semi-structured, meaning we will loosely follow a list of questions. You will be able to look at this list during the interview.

Involvement in the research is entirely voluntary. Your consent may be withdrawn at any time until all the interviews have been collected (by April 2018). We will record the interview. The information you provide will be kept strictly confidential and your name will never be used in any project reports, publications or presentations. You can ask any questions about the study at any time, can receive a copy of your interview recording, and can read over and comment on a short written summary of your interview.

If you accept this invitation, what are your rights as a research participant?

- choose not to answer any question;

- ask for the recorder to be turned off at any time during the interview;

- withdraw from the study before April 2018;

- ask any questions about the study at any time;

- receive a copy of your interview recording;

- read over and comment on a written summary of your interview;

- be able to read any reports of this research by emailing the researcher to request a copy. 


\section{Document 2-1 Participant information sheet (continued)}
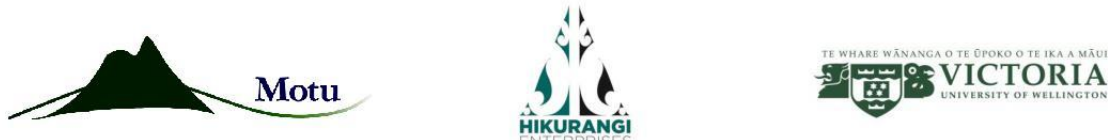

Further details about the research

- Research team: David Fleming and Suzi Kerr (Motu Economic Research), Pia Pohatu and Manu Caddie (Hikurangi Enterprises), Sandra Cortés-Acosta and Leo Mercer (Victoria University of Wellington).

- Research funding and duration: This is a three-year investigation funded by the Ministry for Primary Industries (MPI).

- Research organisations: This work is a collaboration between Motu Economic Research, Hikurangi Enterprises and Victoria University of Wellington.

- Motu Economic and Public Policy Research is an independent economic research institute which never advocates an expressed ideology or political position. A charitable trust, Motu is founded on the belief that sound public policy depends on sound research accompanied by rigorous public debate.

- Hikurangi Enterprises Ltd is a charitable company based in Ruatoria. The company operates a range of trading ventures and forms partnerships with other companies to generate income for its shareholder and create local employment.

- Human Ethics Committee information:

- This research has been approved by the Victoria University of Wellington Human Ethics Committee 25490

- If you have any concerns about the ethical conduct of the research you may contact the Victoria University HEC Convener: Associate Professor Susan Corbett. Email susan.corbett@vuw.ac.nz or telephone +64-4-463 5480

If you have any questions you can contact the researchers:

Sandra Cortés-Acosta, PhD Student, Victoria University of Wellington. Email sandra.cortes-acosta@vuw.ac.nz David Fleming, Fellow, Motu Economic Research. Email david.fleming@motu.org.nz

Pia Pohatu, Ruatoria-based researcher, Hikurangi Enterprises. Email pia@uritukuiho.org.nz

Manu Caddie, Business Development Manager, Hikurangi Enterprises. Email manu@hikurangi.enterprises 


\section{Document 2-2 Consent form}
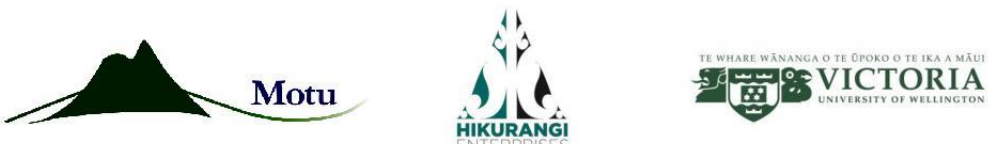

Lessons from restoring native forest through carbon farming on Māori land in Aotearoa New Zealand CONSENT TO INTERVIEW

This consent form will be held for three years.

I have been read and understand the description of the research project. I have had the opportunity to ask questions, and understand that I can ask any further questions at any time.

I understand that:

- Participation is voluntary, and I may withdraw my participation and any information provided without the need for justification at any time up until all the interviews are completed, in April 2018.

- I will have access to the interview recording and summary notes, if requested.

- The information I provide is confidential and my name will not be used in any project reports, publications or presentations.

- Any information I provide will be kept confidential to the researchers.

- Any information I have provided that identifies me will be destroyed immediately after the conclusion of the research.

- I understand that the results will be used for a PhD dissertation, reports and/or presented at conferences.

On this basis, I agree to participate in this project by participating in a face-to-face interview. I also agree to the interview being recorded.

\section{Name (participant)}

Email address

Signed.

Date

I would like a copy of the recording of my interview:

I would like a summary of my interview:

I would like to receive a copy of the final report:

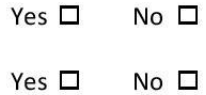

Yes $\square \quad$ No $\square$ 


\section{Document 2-3 Question guide}

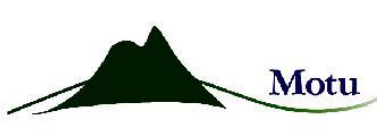

Lessons from restoring native forest through carb
Zealand

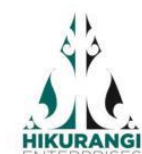

HIKURANG

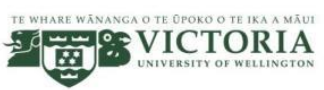

Questions guide

The core component of the research involves a series of semi-structured interviews with trustees or committee members from Māori land blocks.

The interviews will focus on the perceptions towards carbon farming programs, the nature of decision-making processes, strengths and weaknesses of potential final agreement reached in the contracts of carbon farming projects and the risks and opportunities of current and future contracts for carbon farming.

Example of questions:

I. Preferences

a. Current goals and vision overall for the whenua (land)

b. Cultural values involved in the management of the whenua

c. View of "native forest" and scrub (i.e. Manuka/Kanuka)

d. Perception of climate change and sustainability

e. Risk and preferences toward enterprise diversification (i.e. dairy to forestry) of activities (ag and/or forests)

f. considerations toward future generations

II. Management of the land

a. Current enterprises (i.e. forestry, dairy) on the whenua (area, duration of enterprise etc.)

b. Enterprise changes in the last 10 years

c. Enterprise diversification possibilities in the future

d. Improvements desired on the whenua

III. Information

a. Regarding each of: Emission trading scheme (ETS), Erosion control funding programme (ECFP), Permanent Forest Sink Initiative (PFSI), Afforestation Grant Scheme (AGS) and similar carbon sequestration programs/initiatives.

- Awareness / Opportunities / Costs / Rules / Risk

b. Government policies

- Awareness / source of the information/Opinion 
Document 2-3 Question guide (continued)

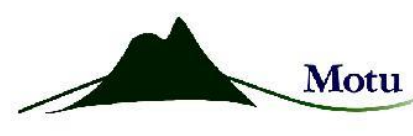

c. Knowledge about their whenua

- Area that are more or less productive in their whenua

- Vulnerabilities (pests, weather, volatility)

\section{About past negotiation/agreement processes}

a. Strengths and weaknesses of agreements reached, if any

b. Risks and opportunities of partnership and carbon farming initiatives

c. Considerations betwen short and long-term returns and management of risks

\section{Recommendations or advice for allocating whenua}

a. Evaluation of the effectiveness of different approaches (carbon storage, erosion control and water quality) for a range of outcomes (financial, production, social, biodiversity, cultural and employment)

b. Possible improvement in the contracts 


\section{Appendix C}

Figure A3-1 Māori freehold land with and without structure by Māori Land Court Districts: North Island

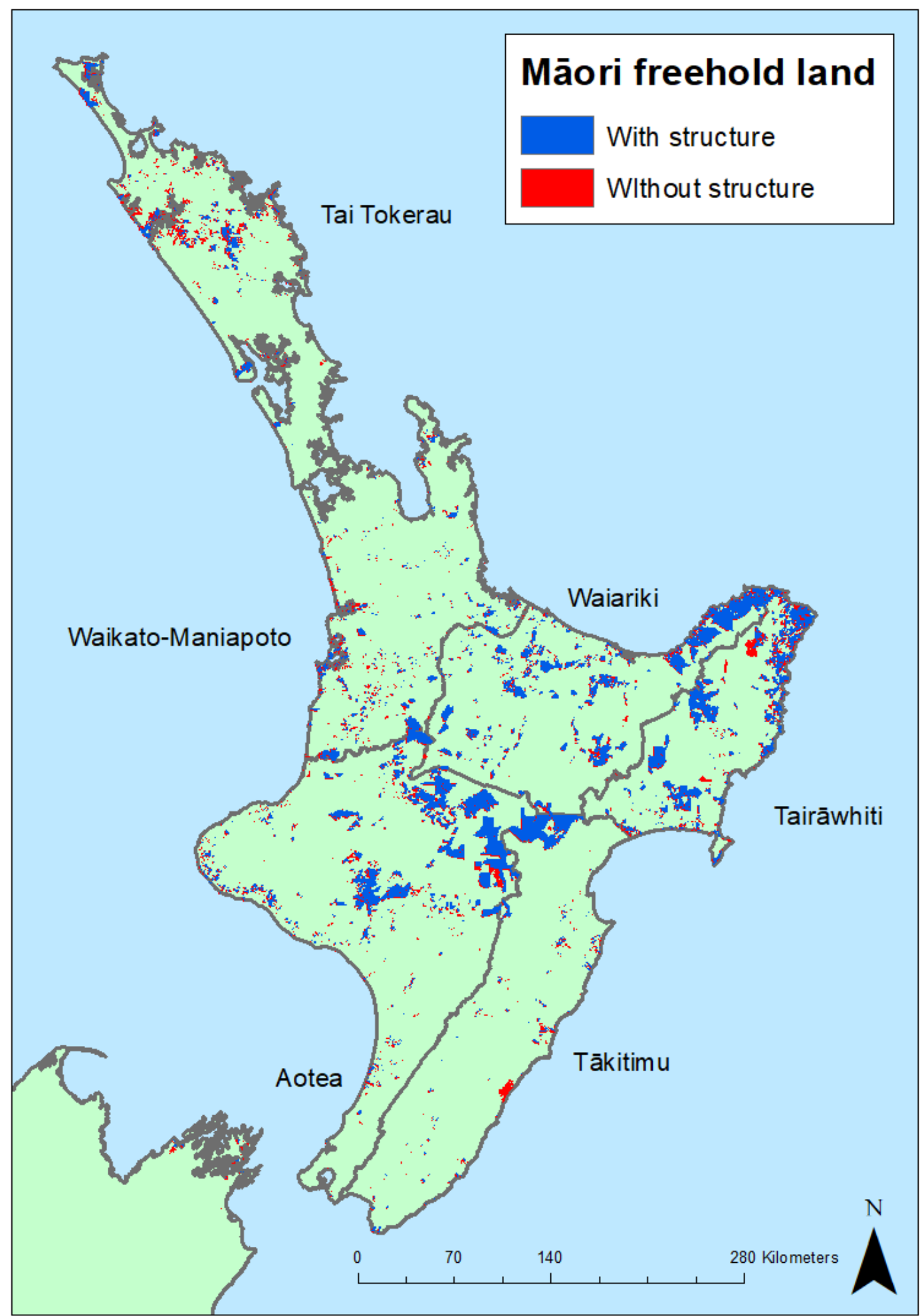


Figure A3-2 Māori freehold land with and without structure by Māori Land Court Districts: South Island

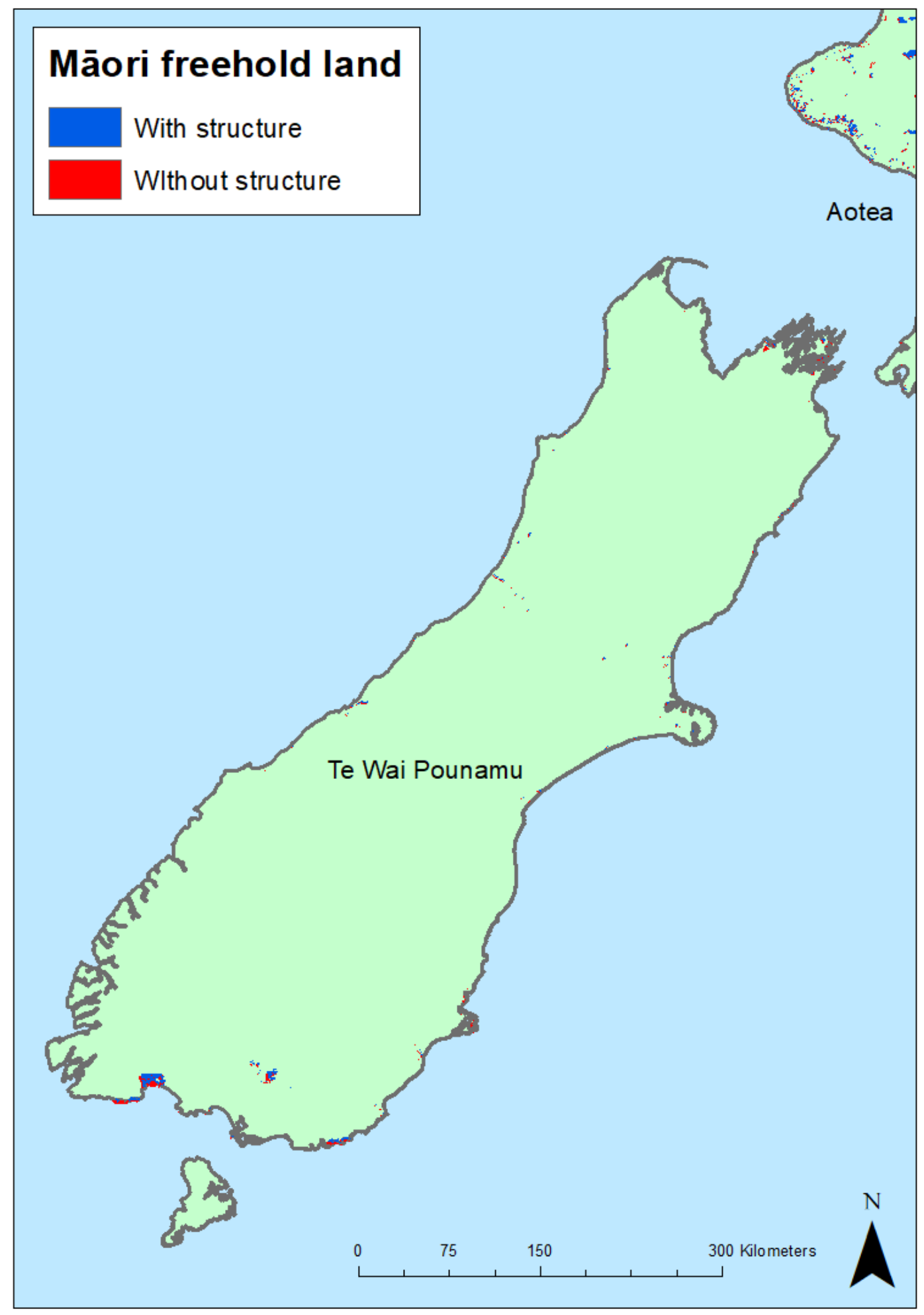


Table A3-1 Coefficient estimates for land-cover shares 2012 - Māori freehold land relative to general land

\begin{tabular}{|c|c|c|c|c|c|c|c|c|c|c|c|c|}
\hline \multirow[t]{2}{*}{ Variable } & \multicolumn{3}{|c|}{ Horticulture } & \multicolumn{3}{|c|}{ Pasture } & \multicolumn{3}{|c|}{ Forestry } & \multicolumn{3}{|c|}{ Indigenous forest } \\
\hline & (1) & (2) & (3) & (1) & (2) & (3) & (1) & (2) & (3) & (1) & (2) & (3) \\
\hline Māori freehold land & $\begin{array}{c}-0.761^{* * *} \\
(0.056)\end{array}$ & $\begin{array}{c}-0.647^{* * *} \\
(0.159)\end{array}$ & $\begin{array}{c}-0.776^{* * *} \\
(0.166)\end{array}$ & $\begin{array}{l}-1.383^{* * *} \\
(0.015)\end{array}$ & $\begin{array}{l}-1.371^{* * *} \\
(0.046)\end{array}$ & $\begin{array}{l}-1.277^{* * *} \\
(0.046)\end{array}$ & $\begin{array}{l}-0.825^{* * *} \\
(0.018)\end{array}$ & $\begin{array}{l}-0.836^{* * *} \\
(0.055)\end{array}$ & $\begin{array}{l}-0.766^{* * *} \\
(0.055)\end{array}$ & $\begin{array}{l}-0.080^{* * *} \\
(0.016)\end{array}$ & $\begin{array}{l}-0.103^{* *} \\
(0.050)\end{array}$ & $\begin{array}{l}-0.024 \\
(0.050)\end{array}$ \\
\hline Land use capability (LUC) ( & & & & & & & & & & & & \\
\hline LUC classes 1-2 & $\begin{array}{c}4.054^{* * *} \\
(0.092)\end{array}$ & $\begin{array}{c}4.070^{* * *} \\
(0.277)\end{array}$ & $\begin{array}{c}4.144^{* * *} \\
(0.289)\end{array}$ & $\begin{array}{l}2.774^{* * *} \\
(0.053)\end{array}$ & $\begin{array}{l}2.927^{* * *} \\
(0.173)\end{array}$ & $\begin{array}{l}2.821^{* * *} \\
(0.161)\end{array}$ & $\begin{array}{l}-0.326^{* * *} \\
(0.063)\end{array}$ & $\begin{array}{l}-0.102 \\
(0.199)\end{array}$ & $\begin{array}{l}-0.277 \\
(0.190)\end{array}$ & $\begin{array}{l}-0.229 * * * \\
(0.079)\end{array}$ & $\begin{array}{l}-0.147 \\
(0.249)\end{array}$ & $\begin{array}{l}-0.263 \\
(0.248)\end{array}$ \\
\hline LUC class 3 & $\begin{array}{c}2.742^{* * *} \\
(0.080)\end{array}$ & $\begin{array}{c}2.663^{* * *} \\
(0.232)\end{array}$ & $\begin{array}{c}2.824^{* * *} \\
(0.251)\end{array}$ & $\begin{array}{l}2.047^{* * *} \\
(0.030)\end{array}$ & $\begin{array}{l}2.112^{* * *} \\
(0.092)\end{array}$ & $\begin{array}{l}2.038^{* * *} \\
(0.089)\end{array}$ & $\begin{array}{l}0.069^{* *} \\
(0.034)\end{array}$ & $\begin{array}{l}0.111 \\
(0.106)\end{array}$ & $\begin{array}{l}0.049 \\
(0.103)\end{array}$ & $\begin{array}{l}-0.161^{* * *} \\
(0.044)\end{array}$ & $\begin{array}{l}-0.145 \\
(0.135)\end{array}$ & $\begin{array}{l}-0.143 \\
(0.133)\end{array}$ \\
\hline LUC class 4 & $\begin{array}{c}1.048^{* * *} \\
(0.079)\end{array}$ & $\begin{array}{c}0.941^{* * *} \\
(0.228)\end{array}$ & $\begin{array}{c}1.079^{* * *} \\
(0.249)\end{array}$ & $\begin{array}{l}1.189^{* * *} \\
(0.021)\end{array}$ & $\begin{array}{l}1.215^{* * *} \\
(0.064)\end{array}$ & $\begin{array}{l}1.183^{* * *} \\
(0.063)\end{array}$ & $\begin{array}{l}0.294^{* * *} \\
(0.024)\end{array}$ & $\begin{array}{l}0.342^{* * *} \\
(0.073)\end{array}$ & $\begin{array}{l}0.292^{* * *} \\
(0.073)\end{array}$ & $\begin{array}{l}-0.019 \\
(0.029)\end{array}$ & $\begin{array}{l}0.014 \\
(0.086)\end{array}$ & $\begin{array}{l}0.004 \\
(0.086)\end{array}$ \\
\hline LUC classes 5-6 & $\begin{array}{c}-0.181^{* *} \\
(0.082)\end{array}$ & $\begin{array}{c}-0.365 \\
(0.241)\end{array}$ & $\begin{array}{c}0.038 \\
(0.256)\end{array}$ & $\begin{array}{l}0.399 * * * \\
(0.011)\end{array}$ & $\begin{array}{l}0.356^{* * *} \\
(0.033)\end{array}$ & $\begin{array}{l}0.358^{* * *} \\
(0.033)\end{array}$ & $\begin{array}{l}-0.159^{* * *} \\
(0.014)\end{array}$ & $\begin{array}{l}-0.220^{* * *} \\
(0.041)\end{array}$ & $\begin{array}{l}-0.162^{* * *} \\
(0.041)\end{array}$ & $\begin{array}{l}-0.368^{* * *} \\
(0.014)\end{array}$ & $\begin{array}{l}-0.424^{* * *} \\
(0.042)\end{array}$ & $\begin{array}{l}-0.403^{* * *} \\
(0.043)\end{array}$ \\
\hline Slope of the land & $\begin{array}{c}-0.319^{* * *} \\
(0.006)\end{array}$ & $\begin{array}{c}-0.335^{* * *} \\
(0.017)\end{array}$ & $\begin{array}{c}-0.318^{* * *} \\
(0.017)\end{array}$ & $\begin{array}{l}-0.067^{* * *} \\
(0.001)\end{array}$ & $\begin{array}{l}-0.067^{* * *} \\
(0.002)\end{array}$ & $\begin{array}{l}-0.067^{* * *} \\
(0.002)\end{array}$ & $\begin{array}{l}-0.064^{* * *} \\
(0.001)\end{array}$ & $\begin{array}{l}-0.064^{* * *} \\
(0.002)\end{array}$ & $\begin{array}{l}-0.066^{* * *} \\
(0.002)\end{array}$ & $\begin{array}{l}0.002^{* *} \\
(0.001)\end{array}$ & $\begin{array}{l}-0.003 \\
(0.002)\end{array}$ & $\begin{array}{l}0.004^{*} \\
(0.002)\end{array}$ \\
\hline Distance to supermarkets & $\begin{array}{c}-0.200^{* * *} \\
(0.009)\end{array}$ & $\begin{array}{c}-0.196^{* * *} \\
(0.026)\end{array}$ & $\begin{array}{c}-0.221^{* * *} \\
(0.028)\end{array}$ & $\begin{array}{l}0.015^{* * *} \\
(0.001)\end{array}$ & $\begin{array}{l}0.016^{* * *} \\
(0.004)\end{array}$ & $\begin{array}{l}0.013^{* * *} \\
(0.004)\end{array}$ & $\begin{array}{l}0.013^{* * *} \\
(0.002)\end{array}$ & $\begin{array}{l}0.014^{* * *} \\
(0.005)\end{array}$ & $\begin{array}{l}0.010^{* *} \\
(0.005)\end{array}$ & $\begin{array}{l}0.035^{* * *} \\
(0.001)\end{array}$ & $\begin{array}{l}0.042^{* * *} \\
(0.004)\end{array}$ & $\begin{array}{l}0.035^{* * *} \\
(0.004)\end{array}$ \\
\hline Distance to ports & $\begin{array}{c}-0.089^{* * *} \\
(0.002)\end{array}$ & $\begin{array}{c}-0.099 * * * \\
(0.007)\end{array}$ & $\begin{array}{c}-0.087^{* * *} \\
(0.007)\end{array}$ & $\begin{array}{l}0.004^{* * *} \\
(0.001)\end{array}$ & $\begin{array}{l}0.001 \\
(0.003)\end{array}$ & $\begin{array}{l}0.005^{*} \\
(0.003)\end{array}$ & $\begin{array}{l}-0.042^{* * *} \\
(0.001)\end{array}$ & $\begin{array}{l}-0.046^{* * *} \\
(0.003)\end{array}$ & $\begin{array}{l}-0.039 * * * \\
(0.003)\end{array}$ & $\begin{array}{l}0.008^{* * *} \\
(0.001)\end{array}$ & $\begin{array}{l}0.003 \\
(0.003)\end{array}$ & $\begin{array}{l}0.008^{* *} \\
(0.003)\end{array}$ \\
\hline North Island & $\begin{array}{c}-1.165^{* * *} \\
(0.020)\end{array}$ & $\begin{array}{c}-1.155^{* * *} \\
(0.061)\end{array}$ & $\begin{array}{c}-1.204^{* * *} \\
(0.061)\end{array}$ & $\begin{array}{l}-0.352^{* * *} \\
(0.010)\end{array}$ & $\begin{array}{l}-0.339^{* * *} \\
(0.030)\end{array}$ & $\begin{array}{l}-0.373^{* * *} \\
(0.030)\end{array}$ & $\begin{array}{l}0.358^{* * *} \\
(0.012)\end{array}$ & $\begin{array}{l}0.350^{* * *} \\
(0.037)\end{array}$ & $\begin{array}{l}0.386^{* * *} \\
(0.037)\end{array}$ & $\begin{array}{l}1.239^{* * *} \\
(0.016)\end{array}$ & $\begin{array}{l}1.237^{* * *} \\
(0.048)\end{array}$ & $\begin{array}{l}1.273^{* * *} \\
(0.048)\end{array}$ \\
\hline Constant & $\begin{array}{c}1.021^{* * *} \\
(0.083)\end{array}$ & $\begin{array}{c}1.311^{* * *} \\
(0.238)\end{array}$ & $\begin{array}{c}0.983^{* * *} \\
(0.264)\end{array}$ & $\begin{array}{l}2.268^{* * *} \\
(0.018)\end{array}$ & $\begin{array}{l}2.327^{* * *} \\
(0.056)\end{array}$ & $\begin{array}{l}2.272^{* * *} \\
(0.056)\end{array}$ & $\begin{array}{l}1.440^{* * *} \\
(0.023)\end{array}$ & $\begin{array}{l}1.536^{* * *} \\
(0.069)\end{array}$ & $\begin{array}{l}1.411^{* * *} \\
(0.069)\end{array}$ & $\begin{array}{l}-1.262^{* * *} \\
(0.027)\end{array}$ & $\begin{array}{l}-1.103^{* * *} \\
(0.080)\end{array}$ & $\begin{array}{l}-1.330^{* * *} \\
(0.080)\end{array}$ \\
\hline Observations & 673,483 & 74,900 & 74,900 & 673,483 & 74,900 & 74,900 & 673,483 & 74,900 & 74,900 & 673,483 & 74,900 & 74,900 \\
\hline Pseudo R-squared & 0.164 & 0.165 & 0.166 & 0.164 & 0.165 & 0.166 & 0.164 & 0.165 & 0.166 & 0.164 & 0.165 & 0.166 \\
\hline Log likelihood & -603606 & -67224 & -67154 & -603606 & -67224 & -67154 & -603606 & -67224 & -67154 & -603606 & -67224 & -67154 \\
\hline
\end{tabular}

Robust standard errors in parentheses

${ }^{* * *} \mathrm{p}<0.01,{ }^{* *} \mathrm{p}<0.05{ }^{*} \mathrm{p}<0.1$

Note: In Column 2, the sample is restricted to the spatial sample 'SG3', which I draw by selecting every third pixel in the X-and Y-direction. In Column 3, the sample is restricted to the random spatial sample 'RS' by selecting a random sample size based on SG3. 
Table A3-2 Coefficient estimates for land-cover shares 2012 - Māori freehold land with structure relative to Māori freehold land without structure

\begin{tabular}{|c|c|c|c|c|c|c|c|c|c|c|c|c|}
\hline \multirow[t]{2}{*}{ Variable } & \multicolumn{3}{|c|}{ Horticulture } & \multicolumn{3}{|c|}{ Pasture } & \multicolumn{3}{|c|}{ Forestry } & \multicolumn{3}{|c|}{ Indigenous forest } \\
\hline & (1) & (2) & (3) & (1) & (2) & (3) & (1) & (2) & (3) & (1) & (2) & (3) \\
\hline \multirow[t]{2}{*}{ Māori freehold land with structure } & $0.461^{* * *}$ & 0.416 & 0.217 & $0.450^{* * *}$ & $0.399^{* * *}$ & $0.273^{* *}$ & $1.714^{* * *}$ & $1.787^{* * *}$ & $2.116^{* * *}$ & $0.068^{*}$ & 0.026 & 0.074 \\
\hline & $(0.121)$ & $(0.355)$ & $(0.357)$ & $(0.036)$ & $(0.108)$ & $(0.108)$ & $(0.062)$ & $(0.192)$ & $(0.223)$ & $(0.035)$ & $(0.106)$ & $(0.110)$ \\
\hline \multirow[t]{2}{*}{ Māori freehold land } & $-1.136^{* * *}$ & $-0.986^{* * *}$ & $-0.968 * * *$ & $-1.747^{* * *}$ & $-1.694^{* * *}$ & $-1.500^{* * *}$ & $-2.323^{* * *}$ & $-2.403^{* * *}$ & $-2.662^{* * *}$ & $-0.127^{* * *}$ & -0.118 & -0.079 \\
\hline & $(0.104)$ & $(0.310)$ & $(0.305)$ & $(0.033)$ & $(0.098)$ & $(0.098)$ & $(0.060)$ & $(0.185)$ & $(0.218)$ & $(0.033)$ & $(0.098)$ & $(0.101)$ \\
\hline \multicolumn{13}{|l|}{ Land use capability (LUC) (base $=7-8)$} \\
\hline \multirow[t]{2}{*}{ LUC classes $1-2$} & $4.063^{* * *}$ & $4.077^{* * *}$ & $4.151^{* * *}$ & $2.783^{* * *}$ & $2.934^{* * *}$ & $2.827^{* * *}$ & $-0.311^{* * *}$ & -0.090 & -0.261 & $-0.229 * * *$ & -0.148 & -0.262 \\
\hline & $(0.092)$ & $(0.277)$ & $(0.289)$ & $(0.053)$ & $(0.173)$ & $(0.161)$ & $(0.063)$ & $(0.199)$ & $(0.190)$ & $(0.079)$ & $(0.249)$ & $(0.248)$ \\
\hline \multirow[t]{2}{*}{ LUC class 3} & $2.748^{* * *}$ & $2.666^{* * *}$ & $2.829 * * *$ & $2.053^{* * *}$ & $2.116^{* * *}$ & $2.042^{* * *}$ & $0.079 * *$ & 0.118 & 0.059 & $-0.162^{* * *}$ & -0.146 & -0.144 \\
\hline & $(0.080)$ & $(0.232)$ & $(0.251)$ & $(0.030)$ & $(0.092)$ & $(0.089)$ & $(0.034)$ & $(0.106)$ & $(0.103)$ & $(0.044)$ & $(0.135)$ & $(0.133)$ \\
\hline \multirow[t]{2}{*}{ LUC class 4} & $1.052^{* * *}$ & $0.947^{* * *}$ & $1.083^{* * *}$ & $1.193^{* * *}$ & $1.221^{* * *}$ & $1.186^{* * *}$ & $0.301^{* * *}$ & $0.353^{* * *}$ & $0.299^{* * *}$ & -0.019 & 0.013 & 0.003 \\
\hline & $(0.079)$ & $(0.228)$ & $(0.249)$ & $(0.021)$ & $(0.064)$ & $(0.063)$ & $(0.024)$ & $(0.073)$ & $(0.073)$ & $(0.029)$ & $(0.086)$ & $(0.086)$ \\
\hline \multirow[t]{2}{*}{ LUC classes 5-6 } & $-0.178^{* *}$ & -0.362 & 0.040 & $0.402^{* * *}$ & $0.359^{* * *}$ & $0.360^{* * *}$ & $-0.154^{* * *}$ & $-0.213^{* * *}$ & $-0.158^{* * *}$ & $-0.369 * * *$ & $-0.424^{* * *}$ & $-0.403^{* * *}$ \\
\hline & $(0.082)$ & $(0.241)$ & $(0.256)$ & $(0.011)$ & $(0.033)$ & $(0.033)$ & $(0.014)$ & $(0.041)$ & $(0.041)$ & $(0.014)$ & $(0.042)$ & $(0.043)$ \\
\hline \multirow[t]{2}{*}{ Slope of the land } & $-0.319^{* * *}$ & $-0.335^{* * *}$ & $-0.318^{* * *}$ & $-0.067^{* * *}$ & $-0.067^{* * *}$ & $-0.067^{* * *}$ & $-0.064^{* * *}$ & $-0.064^{* * *}$ & $-0.065^{* * *}$ & $0.002^{* *}$ & -0.003 & $0.004^{*}$ \\
\hline & $(0.006)$ & $(0.017)$ & $(0.017)$ & $(0.001)$ & $(0.002)$ & $(0.002)$ & $(0.001)$ & $(0.002)$ & $(0.002)$ & $(0.001)$ & $(0.002)$ & $(0.002)$ \\
\hline \multirow{2}{*}{ Distance to supermarkets } & $-0.201^{* * *}$ & $-0.196^{* * *}$ & $-0.222^{* * *}$ & $0.014^{* * *}$ & $0.015^{* * *}$ & $0.013^{* * *}$ & $0.012^{* * *}$ & $0.013^{* * *}$ & $0.008^{*}$ & $0.035^{* * *}$ & $0.042^{* * *}$ & $0.035^{* * *}$ \\
\hline & $(0.009)$ & $(0.026)$ & $(0.028)$ & $(0.001)$ & $(0.004)$ & $(0.004)$ & $(0.002)$ & $(0.005)$ & $(0.005)$ & $(0.001)$ & $(0.004)$ & $(0.004)$ \\
\hline \multirow[t]{2}{*}{ Distance to ports } & $-0.089 * * *$ & $-0.098^{* * *}$ & $-0.087^{* * *}$ & $0.004^{* * *}$ & 0.001 & $0.005^{* *}$ & $-0.042^{* * *}$ & $-0.046^{* * *}$ & $-0.039 * * *$ & $0.008^{* * *}$ & 0.003 & $0.008^{* *}$ \\
\hline & $(0.002)$ & $(0.007)$ & $(0.007)$ & $(0.001)$ & $(0.003)$ & $(0.003)$ & $(0.001)$ & $(0.003)$ & $(0.003)$ & $(0.001)$ & $(0.003)$ & $(0.003)$ \\
\hline \multirow{2}{*}{ North Island } & $-1.167^{* * *}$ & $-1.157^{* * *}$ & $-1.204^{* * *}$ & $-0.354^{* * *}$ & $-0.340^{* * *}$ & $-0.374^{* * *}$ & $0.355^{* * *}$ & $0.347^{* * *}$ & $0.384^{* * *}$ & $1.240^{* * *}$ & $1.238^{* * *}$ & $1.273^{* * *}$ \\
\hline & $(0.020)$ & $(0.061)$ & $(0.061)$ & $(0.010)$ & $(0.030)$ & $(0.030)$ & $(0.012)$ & $(0.037)$ & $(0.037)$ & $(0.016)$ & $(0.048)$ & $(0.048)$ \\
\hline Observations & 673,483 & 74,900 & 74,900 & 673,483 & 74,900 & 74,900 & 673,483 & 74,900 & 74,900 & 673,483 & 74,900 & 74,900 \\
\hline Pseudo R-squared & 0.165 & 0.166 & 0.167 & 0.165 & 0.166 & 0.167 & 0.165 & 0.166 & 0.167 & 0.165 & 0.166 & 0.167 \\
\hline Log likelihood & -603024 & -67061 & -66982 & -603024 & -67061 & -66982 & -603024 & -67061 & -66982 & -603024 & -67061 & -66982 \\
\hline
\end{tabular}

\section{Robust standard errors in parentheses}

$* * * \mathrm{p}<0.01,{ }^{* *} \mathrm{p}<0.05, * \mathrm{p}<0.1$ 
Table A3-3 Coefficient estimates for land-cover transitions 1997-2012 - Māori freehold land relative to general land

\begin{tabular}{|c|c|c|c|c|}
\hline \multirow{2}{*}{$\begin{array}{c}\text { Starting land } \\
\text { cover } 1997\end{array}$} & \multirow{2}{*}{ Variable } & \multicolumn{3}{|c|}{ Outcome land cover 2012} \\
\hline & & Pasture & Forestry & Scrub \\
\hline \multirow{24}{*}{ Pasture } & Māori freehold land & $-0.282^{* * *}$ & $-0.233^{* * *}$ & $1.478^{* * *}$ \\
\hline & & $(0.042)$ & $(0.056)$ & $(0.066)$ \\
\hline & Land use capability (LUC) (base $=7-8$ ) & & & \\
\hline & LUC classes $1-2$ & $2.919^{* * *}$ & $-2.916^{* * *}$ & $-2.932^{* * *}$ \\
\hline & & $(0.113)$ & $(0.120)$ & $(0.327)$ \\
\hline & LUC class 3 & $1.833^{* * *}$ & $-1.810^{* * *}$ & $-1.993^{* * *}$ \\
\hline & & $(0.057)$ & $(0.061)$ & $(0.167)$ \\
\hline & LUC class 4 & $0.984^{* * *}$ & $-0.953^{* * *}$ & $-1.173^{* * *}$ \\
\hline & & $(0.042)$ & $(0.045)$ & $(0.118)$ \\
\hline & LUC classes 5-6 & $0.197^{* * *}$ & $-0.167^{* * *}$ & $-0.286^{* * *}$ \\
\hline & & $(0.025)$ & $(0.027)$ & $(0.057)$ \\
\hline & Slope of the land & $-0.048^{* * *}$ & $0.041^{* * *}$ & $0.073^{* * *}$ \\
\hline & & $(0.001)$ & $(0.001)$ & $(0.003)$ \\
\hline & Distance to supermarkets & $0.005^{*}$ & -0.004 & -0.013 \\
\hline & & $(0.003)$ & $(0.003)$ & $(0.008)$ \\
\hline & Distance to ports & $0.049^{* * *}$ & $-0.052^{* * *}$ & $-0.033^{* * *}$ \\
\hline & & $(0.002)$ & $(0.002)$ & $(0.005)$ \\
\hline & North Island & $-0.521^{* * *}$ & $0.504^{* * *}$ & $0.576^{* * *}$ \\
\hline & & $(0.023)$ & $(0.024)$ & $(0.062)$ \\
\hline & Constant & $3.231^{* * *}$ & $-3.298^{* * *}$ & $-5.679 * * *$ \\
\hline & & $(0.041)$ & $(0.044)$ & $(0.108)$ \\
\hline & Observations & 452,152 & 452,152 & 452,152 \\
\hline & Pseudo R-squared & 0.0855 & 0.0767 & 0.103 \\
\hline & Log likelihood & -50078 & -43765 & -11439 \\
\hline \multirow{24}{*}{ Forestry } & Māori freehold land & $-1.180^{* * *}$ & $1.180^{* * *}$ & \\
\hline & & $(0.115)$ & $(0.115)$ & \\
\hline & Land use capability (LUC) (base $=7-8$ ) & & & \\
\hline & LUC classes $1-2$ & -0.263 & 0.263 & \\
\hline & & $(0.164)$ & $(0.164)$ & \\
\hline & LUC class 3 & $0.826^{* * *}$ & $-0.826^{* * *}$ & \\
\hline & & $(0.078)$ & $(0.078)$ & \\
\hline & LUC class 4 & $0.776^{* * *}$ & $-0.776^{* * *}$ & \\
\hline & & $(0.067)$ & $(0.067)$ & \\
\hline & LUC classes 5-6 & $0.662^{* * *}$ & $-0.662^{* * *}$ & \\
\hline & & $(0.064)$ & $(0.064)$ & \\
\hline & Slope of the land & $-0.122^{* * *}$ & $0.122^{* * *}$ & \\
\hline & & $(0.005)$ & $(0.005)$ & \\
\hline & Distance to supermarkets & $-0.198^{* * *}$ & $0.198^{* * *}$ & \\
\hline & & $(0.007)$ & $(0.007)$ & \\
\hline & Distance to ports & $-0.007 * *$ & $0.007^{* *}$ & \\
\hline & & $(0.004)$ & $(0.004)$ & \\
\hline & North Island & $0.544^{* * *}$ & $-0.544^{* * *}$ & \\
\hline & & $(0.042)$ & $(0.042)$ & \\
\hline & Constant & $-2.302^{* * *}$ & $2.302^{* * *}$ & \\
\hline & & $(0.088)$ & $(0.088)$ & \\
\hline & Observations & 72,729 & 72,729 & \\
\hline & Pseudo R-squared & 0.123 & 0.123 & \\
\hline & Log likelihood & -11520 & -11520 & \\
\hline
\end{tabular}


Table A3-3 Coefficient estimates for land-cover transitions 1997-2012 - Māori freehold land relative to general land (continued)

\begin{tabular}{|c|c|c|c|c|}
\hline \multirow{2}{*}{$\begin{array}{c}\text { Starting land } \\
\text { cover } 1997\end{array}$} & \multirow{2}{*}{ Variable } & \multicolumn{3}{|c|}{ Outcome land cover 2012} \\
\hline & & Pasture & Forestry & Scrub \\
\hline & \multirow[t]{2}{*}{ Māori freehold land } & $-0.933^{* * *}$ & $-0.669^{* * *}$ & $0.826^{* * *}$ \\
\hline & & $(0.096)$ & $(0.091)$ & $(0.067)$ \\
\hline & \multicolumn{4}{|l|}{ Land use capability (LUC) (base=7-8) } \\
\hline & \multirow[t]{2}{*}{ LUC classes $1-2$} & $-0.497^{*}$ & $-1.471^{* * *}$ & $0.976^{* * *}$ \\
\hline & & $(0.288)$ & $(0.415)$ & $(0.239)$ \\
\hline & \multirow{2}{*}{ LUC class 3} & -0.227 & $-0.614 * * *$ & $0.465^{* * *}$ \\
\hline & & $(0.140)$ & $(0.150)$ & $(0.105)$ \\
\hline & \multirow{2}{*}{ LUC class 4} & $0.576^{* * *}$ & $-0.338^{* * *}$ & $-0.174^{* * *}$ \\
\hline & & $(0.076)$ & $(0.096)$ & $(0.060)$ \\
\hline & \multirow[t]{2}{*}{ LUC classes $5-6$} & $0.340^{* * *}$ & $-0.267^{* * *}$ & -0.028 \\
\hline & & $(0.051)$ & $(0.050)$ & $(0.036)$ \\
\hline \multirow[t]{13}{*}{ Scrub } & \multirow[t]{2}{*}{ Slope of the land } & $-0.049 * * *$ & $-0.034^{* * *}$ & $0.044^{* * *}$ \\
\hline & & $(0.003)$ & $(0.003)$ & $(0.002)$ \\
\hline & \multirow[t]{2}{*}{ Distance to supermarkets } & $-0.069 * * *$ & $-0.018^{* * *}$ & $0.048^{* * *}$ \\
\hline & & $(0.005)$ & $(0.006)$ & $(0.004)$ \\
\hline & \multirow[t]{2}{*}{ Distance to ports } & $0.022^{* * *}$ & $-0.039 * * *$ & $0.005^{* *}$ \\
\hline & & $(0.003)$ & $(0.004)$ & $(0.003)$ \\
\hline & \multirow[t]{2}{*}{ North Island } & $-0.366^{* * *}$ & $-0.405^{* * *}$ & $0.410^{* * *}$ \\
\hline & & $(0.042)$ & $(0.049)$ & $(0.033)$ \\
\hline & \multirow[t]{2}{*}{ Constant } & $-2.465^{* * *}$ & $-1.790^{* * *}$ & $1.329^{* * *}$ \\
\hline & & $(0.082)$ & $(0.085)$ & $(0.060)$ \\
\hline & Observations & 68,795 & 68,795 & 68,795 \\
\hline & Pseudo R-squared & 0.0624 & 0.0312 & 0.0489 \\
\hline & Log likelihood & -10068 & -9358 & -16251 \\
\hline
\end{tabular}

Robust standard errors in parentheses

*** $\mathrm{p}<0.01,{ }^{* *} \mathrm{p}<0.05,{ }^{*} \mathrm{p}<0.1$ 
Table A3-4 Coefficient estimates for land-cover transitions 1997-2012 - Māori freehold land with structure relative to Māori freehold land without structure

\begin{tabular}{|c|c|c|c|c|}
\hline \multirow{2}{*}{$\begin{array}{c}\text { Starting land } \\
\text { cover } 1997\end{array}$} & \multirow{2}{*}{ Variable } & \multicolumn{3}{|c|}{ Outcome land cover 2012} \\
\hline & & Pasture & Forestry & Scrub \\
\hline \multirow{26}{*}{ Pasture } & \multirow{2}{*}{ Māori freehold land with structure } & 0.064 & $0.301^{*}$ & $-0.408^{* * *}$ \\
\hline & & $(0.105)$ & $(0.160)$ & $(0.137)$ \\
\hline & \multirow[t]{2}{*}{ Māori freehold land } & $-0.335^{* * *}$ & $-0.490^{* * *}$ & $1.807^{* * *}$ \\
\hline & & $(0.096)$ & $(0.150)$ & $(0.125)$ \\
\hline & \multicolumn{4}{|l|}{ Land use capability (LUC) (base=7-8) } \\
\hline & \multirow[t]{2}{*}{ LUC classes $1-2$} & $2.919 * * *$ & $-2.916^{* * *}$ & $-2.938^{* * *}$ \\
\hline & & $(0.113)$ & $(0.120)$ & $(0.327)$ \\
\hline & \multirow[t]{2}{*}{ LUC class 3} & $1.833^{* * *}$ & $-1.810^{* * *}$ & $-1.995^{* * *}$ \\
\hline & & $(0.057)$ & $(0.061)$ & $(0.167)$ \\
\hline & \multirow[t]{2}{*}{ LUC class 4} & $0.984^{* * *}$ & $-0.953^{* * *}$ & $-1.175^{* * *}$ \\
\hline & & $(0.042)$ & $(0.045)$ & $(0.118)$ \\
\hline & \multirow[t]{2}{*}{ LUC classes $5-6$} & $0.197^{* * *}$ & $-0.167^{* * *}$ & $-0.285^{* * *}$ \\
\hline & & $(0.025)$ & $(0.027)$ & $(0.057)$ \\
\hline & \multirow[t]{2}{*}{ Slope of the land } & $-0.048^{* * *}$ & $0.041^{* * *}$ & $0.073^{* * *}$ \\
\hline & & $(0.001)$ & $(0.001)$ & $(0.003)$ \\
\hline & \multirow[t]{2}{*}{ Distance to supermarkets } & 0.005 & -0.004 & -0.012 \\
\hline & & $(0.003)$ & $(0.003)$ & $(0.008)$ \\
\hline & \multirow[t]{2}{*}{ Distance to ports } & $0.049^{* * *}$ & $-0.052^{* * *}$ & $-0.033^{* * *}$ \\
\hline & & $(0.002)$ & $(0.002)$ & $(0.005)$ \\
\hline & \multirow[t]{2}{*}{ North Island } & $-0.521^{* * *}$ & $0.504^{* * *}$ & $0.578^{* * *}$ \\
\hline & & $(0.023)$ & $(0.024)$ & $(0.062)$ \\
\hline & \multirow[t]{2}{*}{ Constant } & $3.231^{* * *}$ & $-3.298^{* * *}$ & $-5.680 * * *$ \\
\hline & & $(0.041)$ & $(0.044)$ & $(0.108)$ \\
\hline & Observations & 452,152 & 452,152 & 452,152 \\
\hline & Pseudo R-squared & 0.0855 & 0.0767 & 0.103 \\
\hline & Log likelihood & -50077 & -43763 & -11435 \\
\hline & \multirow[t]{2}{*}{ Māori freehold land with structure } & $-0.832^{* *}$ & $0.832^{* *}$ & \\
\hline & & $(0.363)$ & $(0.363)$ & \\
\hline & Māori freehold land & -0.418 & 0.418 & \\
\hline & & $(0.343)$ & $(0.343)$ & \\
\hline & Land use capability (LUC) (base=7-8) & & & \\
\hline & LUC classes $1-2$ & -0.266 & 0.266 & \\
\hline & & $(0.164)$ & $(0.164)$ & \\
\hline & LUC class 3 & $0.826^{* * *}$ & $-0.826^{* * *}$ & \\
\hline & & $(0.078)$ & $(0.078)$ & \\
\hline & LUC class 4 & $0.778^{* * *}$ & $-0.778^{* * *}$ & \\
\hline & & $(0.067)$ & $(0.067)$ & \\
\hline & LUC classes 5-6 & $0.664^{* * *}$ & $-0.664^{* * *}$ & \\
\hline & & $(0.064)$ & $(0.064)$ & \\
\hline Forestry & Slope of the land & $-0.122^{* * *}$ & $0.122^{* * *}$ & \\
\hline & & $(0.005)$ & $(0.005)$ & \\
\hline & Distance to supermarkets & $-0.198^{* * *}$ & $0.198^{* * *}$ & \\
\hline & & $(0.007)$ & $(0.007)$ & \\
\hline & Distance to ports & $-0.007 * *$ & $0.007^{* *}$ & \\
\hline & & $(0.004)$ & $(0.004)$ & \\
\hline & North Island & $0.543^{* * *}$ & $-0.543^{* * *}$ & \\
\hline & & $(0.042)$ & $(0.042)$ & \\
\hline & Constant & $-2.306^{* * *}$ & $2.306^{* * *}$ & \\
\hline & & $(0.088)$ & $(0.088)$ & \\
\hline & Observations & 72,729 & 72,729 & \\
\hline & Pseudo R-squared & 0.124 & 0.124 & \\
\hline & Log likelihood & -11517 & -11517 & \\
\hline
\end{tabular}


Table A3-4 Coefficient estimates for land-cover transitions 1997-2012 - Māori freehold land with structure relative to Māori freehold land without structure (continued)

\begin{tabular}{|c|c|c|c|c|}
\hline \multirow{2}{*}{$\begin{array}{c}\text { Starting land } \\
\text { cover } 1997\end{array}$} & \multirow{2}{*}{ Variable } & \multicolumn{3}{|c|}{ Outcome land cover 2012} \\
\hline & & Pasture & Forestry & Scrub \\
\hline \multirow{26}{*}{ Scrub } & \multirow[t]{2}{*}{ Māori freehold land with structure } & 0.276 & $0.839 * * *$ & $-0.559 * * *$ \\
\hline & & $(0.219)$ & $(0.259)$ & $(0.167)$ \\
\hline & \multirow[t]{2}{*}{ Māori freehold land } & $-1.143^{* * *}$ & $-1.359 * * *$ & $1.268^{* * *}$ \\
\hline & & $(0.196)$ & $(0.246)$ & $(0.154)$ \\
\hline & \multicolumn{4}{|l|}{ Land use capability (LUC) (base=7-8) } \\
\hline & \multirow[t]{2}{*}{ LUC classes $1-2$} & $-0.495^{*}$ & $-1.466^{* * *}$ & $0.972^{* * *}$ \\
\hline & & $(0.288)$ & $(0.415)$ & $(0.239)$ \\
\hline & \multirow[t]{2}{*}{ LUC class 3} & -0.224 & $-0.607^{* * *}$ & $0.460^{* * *}$ \\
\hline & & $(0.140)$ & $(0.150)$ & $(0.105)$ \\
\hline & \multirow[t]{2}{*}{ LUC class 4} & $0.578^{* * *}$ & $-0.332^{* * *}$ & $-0.178^{* * *}$ \\
\hline & & $(0.076)$ & $(0.096)$ & $(0.060)$ \\
\hline & \multirow[t]{2}{*}{ LUC classes $5-6$} & $0.342^{* * *}$ & $-0.262^{* * *}$ & -0.031 \\
\hline & & $(0.051)$ & $(0.050)$ & $(0.036)$ \\
\hline & \multirow[t]{2}{*}{ Slope of the land } & $-0.049 * * *$ & $-0.034^{* * *}$ & $0.044^{* * *}$ \\
\hline & & $(0.003)$ & $(0.003)$ & $(0.002)$ \\
\hline & \multirow[t]{2}{*}{ Distance to supermarkets } & $-0.070^{* * *}$ & $-0.018^{* * *}$ & $0.048^{* * *}$ \\
\hline & & $(0.005)$ & $(0.006)$ & $(0.004)$ \\
\hline & \multirow[t]{2}{*}{ Distance to ports } & $0.022^{* * *}$ & $-0.039 * * *$ & $0.005^{* *}$ \\
\hline & & $(0.003)$ & $(0.004)$ & $(0.003)$ \\
\hline & \multirow[t]{2}{*}{ North Island } & $-0.366^{* * *}$ & $-0.405^{* * *}$ & $0.410^{* * *}$ \\
\hline & & $(0.042)$ & $(0.050)$ & $(0.033)$ \\
\hline & \multirow[t]{2}{*}{ Constant } & $-2.466^{* * *}$ & $-1.792^{* * *}$ & $1.331^{* * *}$ \\
\hline & & $(0.082)$ & $(0.085)$ & $(0.060)$ \\
\hline & Observations & 68,795 & 68,795 & 68,795 \\
\hline & Pseudo R-squared & 0.0625 & 0.0318 & 0.0492 \\
\hline & Log likelihood & -10067 & -9352 & -16245 \\
\hline
\end{tabular}

Robust standard errors in parentheses

*** $\mathrm{p}<0.01,{ }^{* *} \mathrm{p}<0.05,{ }^{*} \mathrm{p}<0.1$ 


\section{Appendix D}

Table A4-1 Average predicted probability of transition (probability estimates) 1997 2012 , by scenarios

\begin{tabular}{|c|c|c|c|c|}
\hline \multirow{2}{*}{$\begin{array}{l}\text { Starting } \\
\text { land cover }\end{array}$} & \multirow{2}{*}{ Scenarios } & \multicolumn{3}{|c|}{ Outcome land cover 2012} \\
\hline & & Pasture & Forestry & Scrub \\
\hline \multirow{14}{*}{ Pasture } & \multirow{2}{*}{ Scenario Factual 1} & $97.38 \%$ & $2.18 \%$ & $0.44 \%$ \\
\hline & & $(0.000)$ & $(0.000)$ & $(0.000)$ \\
\hline & \multirow{2}{*}{ Scenario 1a } & $97.42 \%$ & $2.20 \%$ & $0.38 \%$ \\
\hline & & $(0.002)$ & $(0.000)$ & $(0.000)$ \\
\hline & \multirow{2}{*}{ Scenario $1 \mathrm{~b}$} & $96.63 \%$ & $1.75 \%$ & $1.63 \%$ \\
\hline & & $(0.001)$ & $(0.001)$ & $(0.001)$ \\
\hline & \multirow{2}{*}{ Scenario 1c } & $96.66 \%$ & $1.83 \%$ & $1.51 \%$ \\
\hline & & $(0.001)$ & $(0.001)$ & $(0.001)$ \\
\hline & \multirow{2}{*}{ Scenario Factual 2} & $95.42 \%$ & $2.40 \%$ & $2.18 \%$ \\
\hline & & $(0.002)$ & $(0.001)$ & $(0.001)$ \\
\hline & \multirow{2}{*}{ Scenario 2a } & $95.19 \%$ & $1.87 \%$ & $2.98 \%$ \\
\hline & & $(0.004)$ & $(0.003)$ & $(0.003)$ \\
\hline & \multirow{2}{*}{ Scenario $2 b$} & $95.47 \%$ & $2.50 \%$ & $2.02 \%$ \\
\hline & & $(0.002)$ & $(0.001)$ & $(0.001)$ \\
\hline \multirow{14}{*}{ Forestry } & \multirow{2}{*}{ Scenario Factual 1} & $4.41 \%$ & $95.59 \%$ & - \\
\hline & & $(0.001)$ & $(0.001)$ & - \\
\hline & \multirow{2}{*}{ Scenario $1 \mathrm{a}$} & $4.64 \%$ & $95.36 \%$ & - \\
\hline & & $(0.001)$ & $(0.001)$ & - \\
\hline & \multirow{2}{*}{ Scenario $1 b$} & $1.53 \%$ & $98.47 \%$ & - \\
\hline & & $(0.002)$ & $(0.002)$ & - \\
\hline & \multirow{2}{*}{ Scenario 1c } & $1.43 \%$ & $98.57 \%$ & \\
\hline & & $(0.002)$ & $(0.002)$ & - \\
\hline & \multirow{2}{*}{ Scenario Factual 2} & $1.42 \%$ & $98.58 \%$ & \\
\hline & & $(0.002)$ & $(0.002)$ & - \\
\hline & \multirow{2}{*}{ Scenario $2 \mathrm{a}$} & $2.94 \%$ & $97.06 \%$ & - \\
\hline & & $(0.009)$ & $(0.009)$ & \\
\hline & \multirow{2}{*}{ Scenario $2 \mathrm{~b}$} & $1.33 \%$ & $98.67 \%$ & - \\
\hline & & $(0.002)$ & $(0.002)$ & - \\
\hline \multirow{14}{*}{ Scrub } & \multirow{2}{*}{ Scenario Factual 1} & $3.63 \%$ & $3.16 \%$ & $93.20 \%$ \\
\hline & & $(0.001)$ & $(0.001)$ & $(0.001)$ \\
\hline & \multirow{2}{*}{ Scenario 1a } & $3.90 \%$ & $3.35 \%$ & $92.74 \%$ \\
\hline & & $(0.001)$ & $(0.001)$ & $(0.001)$ \\
\hline & \multirow{2}{*}{ Scenario $1 \mathrm{~b}$} & $1.59 \%$ & $1.75 \%$ & $96.65 \%$ \\
\hline & & $(0.001)$ & $(0.001)$ & $(0.002)$ \\
\hline & \multirow{2}{*}{ Scenario 1c } & $1.70 \%$ & $2.03 \%$ & $96.25 \%$ \\
\hline & & $(0.002)$ & $(0.002)$ & $(0.002)$ \\
\hline & \multirow{2}{*}{ Scenario Factual 2} & $1.35 \%$ & $1.51 \%$ & $97.14 \%$ \\
\hline & & $(0.001)$ & $(0.001)$ & $(0.002)$ \\
\hline & Scenarin 2a & $1.10 \%$ & $0.76 \%$ & $98.14 \%$ \\
\hline & scenario $\angle \mathrm{a}$ & $(0.002)$ & $(0.002)$ & $(0.003)$ \\
\hline & Scenario & $1.44 \%$ & $1.74 \%$ & $96.80 \%$ \\
\hline & scenarı $\mathrm{Zb}$ & $(0.001)$ & $(0.002)$ & $(0.002)$ \\
\hline
\end{tabular}


Table A4-2 Land-cover transitions 1997 - 2012 in hectares, by scenarios

\begin{tabular}{|c|c|c|c|c|c|}
\hline \multirow{2}{*}{$\begin{array}{c}\text { Starting land } \\
\text { cover } 1997\end{array}$} & \multirow{2}{*}{ Scenarios } & \multicolumn{3}{|c|}{ Outcome land cover 2012} & \multirow{2}{*}{$\begin{array}{l}1997 \\
\text { Total } \\
\end{array}$} \\
\hline & & Pasture & Forestry & Scrub & \\
\hline \multirow{7}{*}{ Pasture } & Scenario Factual 1 & $11,008,175$ & 246,025 & 49,600 & \multirow[t]{4}{*}{$11,303,800$} \\
\hline & Scenario $1 \mathrm{a}$ & $11,012,171$ & 248,280 & 43,338 & \\
\hline & Scenario $1 \mathrm{~b}$ & $10,922,954$ & 198,335 & 184,457 & \\
\hline & Scenario 1c & $10,926,811$ & 206,987 & 171,029 & \\
\hline & Scenario Factual 2 & 359,200 & 9,025 & 8,200 & 376,425 \\
\hline & Scenario 2a & 358,327 & 7,039 & 11,230 & \\
\hline & Scenario $2 \mathrm{~b}$ & 359,371 & 9,414 & 7,620 & \\
\hline \multirow{7}{*}{ Forestry } & Scenario Factual 1 & 80,150 & $1,738,075$ & & \multirow[t]{4}{*}{$1,818,225$} \\
\hline & Scenario 1a & 84,408 & $1,733,817$ & & \\
\hline & Scenario $1 \mathrm{~b}$ & 27,757 & $1,790,468$ & & \\
\hline & Scenario 1c & 25,925 & $1,792,300$ & & \\
\hline & Scenario Factual 2 & 2,075 & 144,175 & \multirow{3}{*}{-} & \multirow[t]{3}{*}{146,250} \\
\hline & Scenario $2 \mathrm{a}$ & 4,300 & 141,950 & & \\
\hline & Scenario $2 \mathrm{~b}$ & 1,939 & 144,311 & & \\
\hline \multirow{7}{*}{ Scrub } & Scenario Factual 1 & 62,475 & 54,425 & $1,602,975$ & \multirow[t]{4}{*}{$1,719,875$} \\
\hline & Scenario $1 \mathrm{a}$ & 67,098 & 57,665 & $1,595,075$ & \\
\hline & Scenario $1 b$ & 27,365 & 30,145 & $1,662,207$ & \\
\hline & Scenario 1c & 29,186 & 34,838 & $1,655,424$ & \\
\hline & Scenario Factual 2 & 3,150 & 3,525 & 226,700 & \multirow[t]{3}{*}{233,375} \\
\hline & Scenario 2a & 2,562 & 1,781 & 229,032 & \\
\hline & Scenario $2 \mathrm{~b}$ & 3,360 & 4,071 & 225,913 & \\
\hline \multirow{7}{*}{$\begin{array}{l}2012 \\
\text { Total }\end{array}$} & Scenario Factual 1 & $11,150,800$ & $2,038,525$ & $1,652,575$ & \\
\hline & Scenario $1 \mathrm{a}$ & $11,163,677$ & $2,039,762$ & $1,638,412$ & \\
\hline & Scenario $1 \mathrm{~b}$ & $10,978,076$ & $2,018,948$ & $1,846,664$ & \\
\hline & Scenario 1c & $10,981,923$ & $2,034,125$ & $1,826,453$ & \\
\hline & Scenario Factual 2 & 364,425 & 156,725 & 234,900 & \\
\hline & Scenario $2 \mathrm{a}$ & 365,189 & 150,770 & 240,261 & \\
\hline & Scenario 2b & 364,669 & 157,796 & 233,533 & \\
\hline
\end{tabular}


Table A4-3 Hectares and emissions estimated, by scenarios -private land

\begin{tabular}{|c|c|c|c|c|c|c|}
\hline & \multirow{3}{*}{ Hectares } & \multirow{3}{*}{$\mathrm{GHG}_{\mathrm{tCO}_{2} \mathrm{eq}}$} & \multirow{3}{*}{$\widehat{\mathbf{G H G}}_{\mathbf{t C O}}{ }_{2}^{*} \mathbf{w e}$} & \multicolumn{3}{|c|}{${\widehat{\mathrm{GHG}_{\mathrm{tCO}}^{2} w e}}_{\mathrm{w}}$ disaggregated } \\
\hline & & & & \multicolumn{2}{|c|}{ Stock gas $\mathrm{tCO}_{2}^{*} w e$} & \multirow{2}{*}{ Flow gas $\mathrm{CH}_{4}-\mathrm{SLCP}$} \\
\hline & & & & $\mathbf{L L C P}_{1}$ & $\mathrm{LLCP}_{2}$ & \\
\hline \multicolumn{7}{|c|}{ Transition from pasture 1997 to forestry 2012} \\
\hline Scenario Factual 1 & 246,025 & $-8,656,010$ & $-13,114,139$ & $-7,830,974$ & $-513,473$ & $-4,769,692$ \\
\hline Scenario 1a & 248,280 & $-8,735,353$ & $-13,234,345$ & $-7,902,754$ & $-518,179$ & $-4,813,412$ \\
\hline Scenario $1 \mathrm{~b}$ & 198,335 & $-6,978,125$ & $-10,572,087$ & $-6,313,014$ & $-413,941$ & $-3,845,133$ \\
\hline Scenario $1 c$ & 206,987 & $-7,282,530$ & $-11,033,271$ & $-6,588,405$ & $-431,998$ & $-4,012,868$ \\
\hline \multicolumn{7}{|c|}{ Transition from pasture 1997 to scrub 2012} \\
\hline Scenario Factual 1 & 49,600 & $-488,731$ & $-1,387,514$ & $-322,400$ & $-103,519$ & $-961,595$ \\
\hline Scenario $1 \mathrm{a}$ & 43,338 & $-427,026$ & $-1,212,332$ & $-281,695$ & $-90,449$ & $-840,188$ \\
\hline Scenario $1 \mathrm{~b}$ & 184,457 & $-1,817,536$ & $-5,160,006$ & $-1,198,968$ & $-384,975$ & $-3,576,064$ \\
\hline Scenario $1 c$ & 171,029 & $-1,685,226$ & $-4,784,376$ & $-1,111,687$ & $-356,950$ & $-3,315,739$ \\
\hline \multicolumn{7}{|c|}{ Transition from forestry 1997 to pasture 2012} \\
\hline Scenario Factual 1 & 80,150 & $2,819,958$ & $4,272,328$ & $2,551,177$ & 167,279 & $1,553,872$ \\
\hline Scenario $1 \mathrm{a}$ & 84,408 & $2,969,766$ & $4,499,293$ & $2,686,707$ & 176,166 & $1,636,420$ \\
\hline Scenario $1 b$ & 27,757 & 976,601 & $1,479,583$ & 883,518 & 57,932 & 538,133 \\
\hline Scenario 1c & 25,925 & 912,143 & $1,381,927$ & 825,204 & 54,108 & 502,615 \\
\hline
\end{tabular}

Note 1: GHG emissions or captures in terms of tonnes of carbon dioxide equivalent $\left(G_{H} G_{t C O_{2} e q}\right)$ and GHG emissions or captures in warming equivalent ( $\widehat{G H G}_{t C O_{2}^{*}}$ we $)$, per hectare per year. 
Table A4-4 Hectares and emissions estimated, by scenarios - Māori freehold land

\begin{tabular}{|c|c|c|c|c|c|c|}
\hline & \multirow{3}{*}{ Hectares } & \multirow{3}{*}{$\mathrm{GHG}_{\mathrm{tCO}_{2} \mathrm{eq}}$} & \multirow{3}{*}{$\widehat{G H G}_{t c o_{2}^{*} \text { we }}$} & \multicolumn{3}{|c|}{$\widehat{G H G}_{t C O_{2}^{*} w e}$ disaggregated } \\
\hline & & & & \multicolumn{2}{|c|}{ Stock gas $\mathrm{tCO}_{2}^{*} \mathrm{we}$} & \multirow{2}{*}{ Flow gas $\mathrm{CH}_{4}-\mathrm{SLCP}$} \\
\hline & & & & LLCP $_{1}$ & LLCP $_{2}$ & \\
\hline \multicolumn{7}{|c|}{ Transition from pasture 1997 to forestry 2012} \\
\hline Scenario Factual 2 & 9,025 & $-317,531$ & $-481,070$ & $-287,266$ & $-18,836$ & $-174,968$ \\
\hline Scenario $2 \mathrm{a}$ & 7,039 & $-247,639$ & $-375,181$ & $-224,036$ & $-14,690$ & $-136,456$ \\
\hline Scenario $2 \mathrm{~b}$ & 9,414 & $-331,214$ & $-501,799$ & $-299,644$ & $-19,648$ & $-182,508$ \\
\hline \multicolumn{7}{|c|}{ Transition from pasture 1997 to scrub 2012} \\
\hline Scenario Factual 2 & 8,200 & $-80,798$ & $-229,388$ & $-53,300$ & $-17,114$ & $-158,974$ \\
\hline Scenario $2 \mathrm{a}$ & 11,230 & $-110,651$ & $-314,140$ & $-72,993$ & $-23,437$ & $-217,710$ \\
\hline Scenario $2 \mathrm{~b}$ & 7,620 & $-75,080$ & $-213,153$ & $-49,528$ & $-15,903$ & $-147,723$ \\
\hline \multicolumn{7}{|c|}{ Transition from forestry 1997 to pasture 2012} \\
\hline Scenario Factual 2 & 2,075 & 73,006 & 110,606 & 66,047 & 4,331 & 40,228 \\
\hline Scenario $2 \mathrm{a}$ & 4,300 & 151,279 & 229,192 & 136,860 & 8,974 & 83,359 \\
\hline Scenario $2 \mathrm{~b}$ & 1,939 & 68,208 & 103,338 & 61,707 & 4,046 & 37,585 \\
\hline
\end{tabular}

Note 1: GHG emissions or captures in terms of tonnes of carbon dioxide equivalent $\left(G H G_{t C O_{2} e q}\right)$ and $G H G$ emissions or captures in warming equivalent $\left(\widehat{G H G}_{t C O_{2}^{*} \text { we }}\right)$, per hectare per year. 